Editora Poisson

\title{
Educação no Século XXI - Volume 16 Diversidade, Responsabilidade Social
}

\author{
1a Edição
}

Belo Horizonte

Poisson

2019 
Editor Chefe: Dr. Darly Fernando Andrade

\section{Conselho Editorial}

Dr. Antônio Artur de Souza - Universidade Federal de Minas Gerais

Ms. Davilson Eduardo Andrade

Msc. Fabiane dos Santos Toledo

Dr. José Eduardo Ferreira Lopes - Universidade Federal de Uberlândia

Dr. Otaviano Francisco Neves - Pontifícia Universidade Católica de Minas Gerais

Dr. Luiz Cláudio de Lima - Universidade FUMEC

Dr. Nelson Ferreira Filho - Faculdades Kennedy

Ms. Valdiney Alves de Oliveira - Universidade Federal de Uberlândia

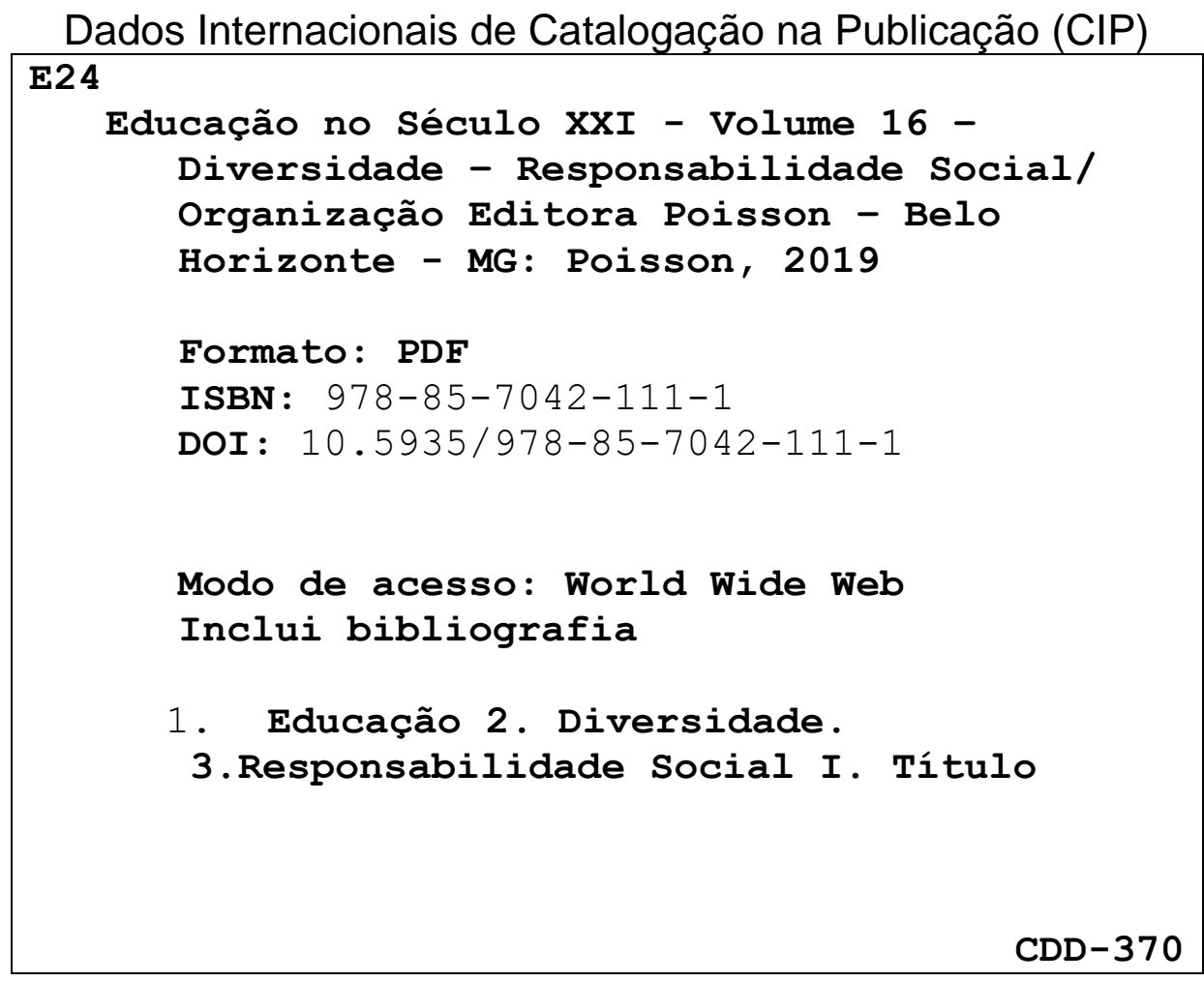

O conteúdo dos artigos e seus dados em sua forma, correção e confiabilidade são de responsabilidade exclusiva dos seus respectivos autores

$\underline{\text { www.poisson.com.br }}$

contato@poisson.com.br 


\section{SUMÁRIO}

Capítulo 1: A desnaturalização do gênero e da sexualidade na escola: Para uma sociedade de respeito às diferenças.

Cibelle Jovem Leal, Liélia Barbosa Oliveira

Capítulo 2:0 discursos sobre gênero no espaço escolar: Configurando identidades a partir de referências normatizadas

Arthur Furtado Bogéa, Iran de Maria Leitão Nunes, João Antônio de Sousa Lira

Capítulo 3:Literatura infantil como ferramenta de inclusão de modelos familiares homoparentais

Magdiel Júnior da Silva, Ana Paula Marques de Araújo, Tatiana Cristina Vasconcelos

Capítulo 4:Diversidades em tela: 0 uso dos recursos audiovisuais como elementos discursivos para superação da desigualdade na escola e do Preconceito de Raça, Gênero e Identidade. 30

Carla Thayse dos Santos alves, Espedito dos Santos Júnior, João Antônio da Silva Fernandes, Maria Eluiza Soares da Silva, Marcos Paulo de Oliveira Sobral

Capítulo 5:De quem se fala e para quem se fala? 0 ensino de Geografia e a diversidade Étnico-Racial 40

Andrêssa Glaucyara Silva Ramos, Maria Dayanny Goncalves, Gabriela Cavalcanti Lucena, Maria Gracielle Vieira Pedroza, Aparecida Carneiro Pires

Capítulo 6:Interculturalidade crítica em processos de aprendizagem e criação em danças Afrorreferenciadas.

Emyle Pompeu de Barros Daltro, Gerson Carlos Matias de Sousa

Capítulo 7:0 currículo e a cultura Afro-Brasileira 54

Leticia Priscila Azevedo de Sousa, Luzia Areal Barros, Maria de Fatima Andrade Costa Henriques

Capítulo 8: Relações de dignidade em contexto de diversidade: Um estudo na feira central de Campina Grande

Francilene Araújo de Morais, Maria Luisa Mendes Teixeira

Capítulo 9:A formação do Professor Indígena sob o viés da interculturalidade 71 


\section{SUMÁRIO}

Capítulo 10:Currículo escolar em contexto Amazônico: Qual espaço dos saberes locais no currículo? 79

Kézia Siméia Barbosa da Silva Martins, Zildiane Souza Teixeira

Capítulo 11:Vivências corporais humanescentes: Estratégias para reencantar a educação 86

Tereza Cristina Bernardo da Câmara

Capítulo 12:Bullying escolar: Suas consequências e a atuação do serviço social para minimizar essa prática 92

Maria Goretti Rodrigues de S. Oliveira, Dalnes Cristine de F. Godim, Maria Aparecida Pereira, Nájila Brandão da Silva, Maria de Fátima Leite Gomes

Capítulo 13:Educação e Direitos Humanos: Um diálogo voltado para educação intercultural como garantia de direitos.

Camila Mirella Barbosa Raia De Oliveira, Edina Henrique Da Silva Batista

Capítulo 14:0 passado como experiência viva do eu no presente: Os desafios da memória dividida nos escritos de um apenado.

Charles Lamartine de Sousa Freitas, Ana Lúcia Oliveira Aguiar, José Evangelista de Lima, Francinilda Honorato dos Santos, Stenio de Brito Fernandes

Capítulo 15:As condicionalidades do programa bolsa família (PBF) na educação: Um relato de experiência na Escola Municipal Nazinha Barbosa da Franca.

Maria Aparecida Pereira, Maria Goretti Rodrigues de S. Oliveira, Nájila Brandão da Silva

Celyane Souza dos Santos, Maria de Fátima Leite Gomes

Capítulo 16:A importância do FIES na garantia do direito ao ensino superior . 120

Silvana Santos Almeida, Felipe Almeida Garcia Santos

Capítulo 17:A escola no território das cidades: As condições de moradia e suas implicações no descumprimento do programa bolsa família (PBF)

Celyane Souza dos Santos, Caio César Gomes de Moura, Gisele Alves Xavier da Silva, Robéria Viana Correia de Souza, Edna Tânia Ferreira da Silva

Autores: 


\section{Capítulo 1}

A desnaturalização do gênero e da sexualidade na escola: Para uma sociedade de respeito às diferenças

\section{Cibelle Jovem Leal \\ Liélia Barbosa Oliveira}

Resumo: As questões de gênero estão presentes em todas as relações de poderes nos mais variados espaços da sociedade, transmitindo valores e significados que demarcam formas culturais para o "ser homem" e o "ser mulher". Muito embora, os papéis sociais do gênero resultem da construção histórica, parece até inconcebível questionarmos, pois são naturalizados através das teias discursivas e de poderes que permeiam as instâncias sociais. Assim, refletimos sobre possíveis desconstruções e desnaturalizações desses papéis, partindo da escola, já que esta funciona como um mecanismo epistemológico social. Além de privilegiarmos as relações de gênero presentes nesse espaço, consideramos que a sexualidade também é afetada a partir do gênero, pois ao se construir o "sujeito homem" e o "sujeito mulher" de forma universalizante também se instituem as condições sexuais e desejantes destes/as, reproduzindo uma heteronormatividade que contraria a ideia das diferenças e institui padrões de relacionamento para as/os indivíduas/os. Por sua vez, o gênero e a sexualidade estão inseridos como temas transversais nos Programas Curriculares Nacionais-PCN's, mas há uma ausência acerca dessas discussões nas instituições escolares, propiciada até mesmo pela falta de preparo das/os educadoras/es como pelos ataques que os estudos de gênero vêm sofrendo a partir do projeto da "Escola Sem partido" e da "Ideologia de Gênero". Para tanto, propomos métodos a serem usados em sala de aula como auxílio para desnaturalizar os papéis de gênero e de sexualidade, tentando promover reflexões, debates e práticas de respeito pautadas na filosofia da diferença com vistas ao empoderamento das mulheres e da população LGBTQI+.

Palavras-chave: Escola, desnaturalização, gênero, sexualidade, diferenças. 


\section{INTRODUÇÃO}

Quando vivenciamos um trabalho de magistério e lecionamos em uma universidade e/ou escola, nos sentimos atuar em um processo de "melhoria" da sociedade, temos a sensação de que podemos afetar cada discente com valores humanistas. Assim, buscamos construir uma sociedade de respeito às diferenças. Isso, claro, quando partem de docentes cujos seus ensinamentos estão baseados na Filosofia da Diferença, que trata acerca das particularidades e singularidades presentes em cada pessoa ${ }^{1}$. Em contrapartida, sabemos que

[...] a escola delimita espaços. Servindo-se de símbolos e códigos, ela afirma o que cada um pode (ou não pode) fazer, ela separa e institui. Informa o "lugar" dos pequenos e dos grandes, dos meninos e das meninas. Através de seus quadros, crucifixos, santas ou esculturas, aponta aqueles/as que deverão ser modelos e permite, também, que os sujeitos se reconheçam (ou não) nesses modelos. 0 prédio escolar informa a todos/as sua razão de existir. Suas marcas, seus símbolos e arranjos arquitetônicos "fazem sentido", instituem múltiplos sentidos, constituem distintos sujeitos (LOURO, 1997 p. 58).

Pensar na escola enquanto um mecanismo moral, que institui diferenças e separações não é nosso intuito neste trabalho. Muito embora, ela atue de forma governamental na sociedade juntamente com outras instituições ${ }^{2}$ não podemos reduzi-la a um ponto moral $^{3}$ de determinação de ações de outros/as apenas, e esquecê-la enquanto incitadora das práticas humanas sociais e como espaço onde as relações de poder se fazem presentes, permitindo (re)leituras de mundo, questionamentos e (re)invenções.

A escola edificada como um lugar da "racionalidade" e da formação de sujeitos morais, significa muito mais um lugar de sociabilidades diversas, de reflexões, como também, de sensações, emoções, (cri)atividades e subjetividades. Em contrapartida, ao lermos a citação acima, Louro (1997) nos faz perceber que a escola não se trata de um mecanismo neutro na (re)(des)construção dos/as indivíduos/as. Seus códigos, símbolos, arranjos arquitetônicos constroem e são construídas a partir de discursos dizíveis e visíveis, que demarcam lugares e modelos de ser para cada indivíduo/a, muitas vezes inquestionáveis por estarem próximos e visíveis de nós mesmos/as, que de tão naturalizados em nossos corpos não nos perguntamos como foram introduzidos ali. Parece-nos já termos nascido homens e mulheres prontos/as e acabados/as, processados/as em uma fôrma e lançados/as no mundo já predeterminados/as a características sociais relacionadas às nossas genitálias. Nesse sentido, somos enquadrados/as dentro de um conjunto de valores que predeterminam nossos sentidos e pensamentos, além das nossas atuações.

Em contrapartida, temos os estudos de Joan Scott, que veio nos apresentar o gênero como uma "categoria útil de análise", ou seja, nos mostrou que os papéis de homens e de mulheres na nossa sociedade não são naturais, biológicos e determinados de forma imutável em todas as épocas e culturas. No entanto, temos que

[...] revelar as diferenças sexuais e os papéis sociais a partir das significações históricas e socialmente construídas e designadas, de modo relacional, por mulheres e homens [...] Assim, os papéis normativos, os comportamentos atribuídos a homens e mulheres e a relação entre os sexos não são discursos neutros, mas representações construídas repletas de significados e de relações de poder (POSSAS apud GONÇALVES, 2006, p. 73-74).

Mas, não podemos pensar que apenas a escola atue na docilização dos corpos e na formação de indivíduos/as, ela também está emaranhada na teia de micro poderes que envolve a sociedade. É um espaço usado e envolvido pelo poder disciplinar como as demais instituições sociais, que são perpassadas por discursos que tentam internalizar valores morais e condutas para cada pessoa.

\footnotetext{
1 Para entender a Filosofia da Diferença, ver Peters (2000).

2 Compreendemos a ideia de "governo" a partir de Foucault (1983b, p. 221 apud Gore 2010, p. 12): “[...] forma pela qual a conduta dos indivíduos ou grupos podia ser dirigida; o governo das crianças, das almas, das comunidades, das famílias, dos doentes... Governar, nesse sentido, é estruturar o campo possível de ação de outros".

3 "Por 'moral' entende-se um conjunto de valores e regras de ação propostas aos indivíduos e aos grupos por intermédio de aparelhos prescritivos diversos, como podem ser a família, as instituições educativas, as Igrejas etc" (FOUCAULT, 1984, p. 26).
} 
Dessa forma, temos o conceito criado por Michel Foucault de "poder disciplinar", que se pratica de forma invisível por meio das "técnicas normalizadoras do eu" pelo panoptismo (uma organização de vigilância carcerária desenvolvida na França no século XIX, que permitia a visualização de todas as celas, fazendo com que os presos se autorregulassem $)^{4}$.

E essa tecnologia não era exclusiva da prisão, encontrando-se também em outras instituições como o hospital, o exército, a escola, a fábrica [...] E é importante notar que ela nem é um aparelho, nem uma instituição, na medida em que funciona como uma rede que as atravessa sem se limitar a suas fronteiras [...] Ela é uma técnica, um dispositivo, um mecanismo, um instrumento de poder, são "métodos que permitem o controle minucioso das operações do corpo, que asseguram a sujeição constante de suas forças e lhes impõem uma relação de docilidade-utilidade...". É o diagrama de um poder que atua do exterior, mas trabalha o corpo dos homens, manipula seus elementos, produz seus comportamentos, enfim, fabrica o tipo de homem necessário ao funcionamento e manutenção da sociedade industrial, capitalista (grifos nossos) (FOUCAULT, 1979, p. XVII).

No entanto, não podemos considerar o poder como um mecanismo que oprime, que limita, que sufoca, ele também produz, incita resistências e (re)invenções. E, a escola como também inserida nessa teia de micropoderes é um espaço privilegiado para isso. Para as (trans)formações dos/as sujeitos/as sociais, mudanças de valores e regras morais. Desse modo, somos envolvidos/as disciplinarmente por discursos naturalizantes, principalmente, quando isso se refere aos gêneros e às sexualidades, que são os primeiros papéis sociais que recebemos mesmo antes de nascermos, parecendo inerentes a nós.

Nesse sentido, nossa função enquanto educadores/as é "fazer aparecer o que está tão perto, o que é tão imediato, o que está tão intimamente ligado a nós mesmos que exatamente por isso não o percebemos [...] fazer ver o que vemos" (FOUCAULT apud ARTIÉRES, 2004, p. 15).

Tal "naturalidade" tão fortemente construída talvez nos impeça de notar que, no interior das atuais escolas, onde convivem meninos e meninas, rapazes e moças, eles e elas se movimentem, circulem e se agrupem de formas distintas. Observamos, então, que eles parecem "precisar" de mais espaço do que elas, parecem preferir "naturalmente" as atividades ao ar livre. Registramos a tendência nos meninos de "invadir" os espaços das meninas, de interromper suas brincadeiras. E, usualmente, consideramos tudo isso de algum modo inscrito na "ordem das coisas". Talvez também pareça "natural" que algumas crianças possam usufruir de tempo livre, enquanto que outras tenham de trabalhar após o horário escolar; que algumas devam "poupar" enquanto que outras tenham direito a "matar" o tempo. Um longo aprendizado vai, afinal, "colocar cada qual em seu lugar". Mas as divisões de raça, classe, etnia, sexualidade e gênero estão, sem dúvida, implicadas nessas construções e é somente na história dessas divisões que podemos encontrar uma explicação para a "lógica" que as rege (Idem, p. 60).

Assim, na "nossa sociedade, devido à hegemonia branca, masculina, heterossexual e cristã, têm sido nomeados e nomeadas como diferentes aqueles e aquelas que não compartilham desses atributos" (grifo nosso) (LOURO, 1997, p. 50). É importante ressaltarmos que esses valores binários fizeram da nossa sociedade dicotomicamente dualista, instituindo diferenças hierárquicas entre os/as indivíduos/as, o que causa preconceitos, violências e discriminações com pessoas e grupos que contrariam a ordem binária presente na cultura ocidental. Para corroborar com a ideia, sabemos que isso ocorre com "o discurso cultural hegemônico que normatiza as estruturas binárias de sexo e gênero, estabelecendo limites para as possibilidades de configurações do gênero na cultura" (MARIANO, 2005, p. 491).

\footnotetext{
${ }^{4}$ A noção de poder disciplinar é vividamente ilustrada na apresentação que Foucault faz do Panóptico de Bentham: uma estrutura arquitetônica, criada principalmente para as prisões, na qual células individuais na periferia do edifício circundam uma torre central. A contra-iluminação criada por janelas internas e externas permite a observação de cada cela a partir da torre central, assegurando ao mesmo tempo que os prisioneiros não possam saber se estão sendo observados. "Daí o efeito mais importante do Panóptico: induzir no detento um estado consciente e permanente de visibilidade que assegure o funcionamento automático do poder" [...] 0 poder disciplinar torna-se assim, internalizado [...] (FOUCAULT apud GORE, 2010, p. 12).
} 
Dessa forma, Donna Wilshire (1997), apresenta a historicidade de como a cultura ocidental iluminista e positivista se ergueu em dualismos entre masculino (superior, racional e positivo) e o feminino (inferior, emocional e negativo), dicotomias que além de manter uma relação desigual e dualista entre homens e mulheres, também resultou na desvalorização de determinados elementos associados às características femininas, tais como o mito e a natureza.

Os dualismos hierárquicos - com seu privilégio em relação à Mente (isto é, masculinidade) e seus preconceitos contra o corpo e a matéria (isto é, feminidade) - estão na base da epistemologia ocidental e do pensamento moral. Esses preconceitos tornaram-se o núcleo de nossas tradições filosóficas e científicas, não podendo ser eliminados facilmente por, ao menos, duas poderosas razões. Primeiro, as imagens positivas e negativas que acompanham nossas palavras $e$ conceitos de masculino e feminino, são fortes e acumularam milénios de uso. São parte integrante das histórias sagradas que aprendemos na infância, das histórias profanas, das fábulas; são parte e grande parcela de brincadeiras comuns; as imagens associadas tornaram-se uma parte de nossa maneira de pensar. Segundo, julgamentos de valores sexistas são inerentes às próprias palavras que usamos. A tradição precisa finalmente ser vista como é: intrinsecamente unilateral e parcial (grifos nossos) (p. 105).

Essa forma de pensamento ocidental está imbricada em todas as instituições basilares da nossa sociedade, inclusive, na escola. Esta, por sua vez, é um lócus de ciência, de uma ciência ainda pautada pelo e no Iluminismo, assim, "a escola é masculina, pois ali se lida, fundamentalmente, com o conhecimento - e esse conhecimento foi historicamente produzido pelos homens” (LOURO, 2003, p. 89).

A escola, juntamente com outros aparatos que a integram, como os livros didáticos, possuem asserções linguísticas que particularizam a própria linguagem ao masculino, tornando-a universal entre os/as discentes. Muito embora, nos pareça inocente o fato da linguagem presente nos livros didáticos possuir como determinante das palavras o artigo "o" não podemos acreditar na existência da neutralidade, principalmente, quando esta se refere aos mecanismos linguísticos, pelos quais se constroem os/as sujeitos/as, os discursos e os "regimes de verdade" presentes na sociedade. Para tanto, Foucault (2009) nos leva a pensar o seguinte:

O que é afinal um sistema de ensino senão uma ritualização da palavra; senão uma qualificação e uma fixação dos papéis para os sujeitos que falam; senão a constituição de um grupo doutrinário ao menos difuso; senão uma distribuição e uma apropriação do discurso com seus poderes e seus saberes?

Que é uma "escritura" (a dos "escritores") senão um sistema semelhante de sujeição, que toma formas um pouco diferentes, mas cujos grandes planos são análogos? Não constituiriam o sistema judiciário, o sistema institucional da Medicina, eles também, sob certos aspectos, ao menos, tais sistemas de sujeição? (grifo nosso) (FOUCAULT, 2009, p. 44-45).

Assim, tanto autor/a quanto leitor/a estão intrinsecamente envolvidos/as pelos discursos, que se constituem nas relações de poder. Discursos que, trazendo para as questões de gênero, perpassam ainda a ideia da universalidade do que se entende por "homem" e por "mulher". Desse modo, como questionar a universalidade da linguagem masculina presente nos livros didáticos, cujos textos masculinizados são os que primeiramente entramos em contato? Como questionar as brincadeiras e os brinquedos associados a meninos e meninas? Como questionar também, a arquitetura do prédio escolar, que separa os banheiros masculino e feminino, quiçá pela lógica de que a mulher deve se recatar, pois o homem não consegue controlar seus "instintos naturais" sexuais? E, com relação aos espaços esportivos, quando estes existem nas escolas, temos que as práticas esportivas realizadas ao ar livre (lugar público) correspondem aos meninos e às salas de aeróbica (lugar privado e íntimo) os espaços das meninas? Como questionar o que não se "pode" questionar, quando nossas várias identidades culturais se apresentam como naturais em praticamente todos os espaços onde estamos?

Nesse sentido, sabemos que para desnaturalizar ou descontruir os papéis sociais do gênero, que carregam consigo também as normas sexuais, é um processo moroso e meticuloso, haja vista que não só depende da escola, mas de toda a sociedade envolvida com as "pequenas revoltas diárias", rompendo barreiras de preconceitos e permitindo (re)construir maneiras de "ser" diversas e não apenas binárias, como homem e como mulher. Além do mais, sabemos que a sociedade hoje apresenta vários mecanismos que permitem a 
transição do sexo e/ou do gênero. E, por isso, a ideia de duas únicas possibilidades de modelos de existência ou categorias se torna insuficiente no nosso tempo hodierno.

\section{EXPERIÊNCIAS ESCOLARES}

Para percebermos como os papéis de gênero são construídos no interior das escolas, é necessário estarmos inseridos/as nelas e lançarmos um olhar minucioso para cada detalhe. Assim, relatar um pouco das experiências se torna fundamental para a inteligibilidade do que pretendemos mostrar, além de poder contribuir para as mudanças desejadas nos métodos de ensino que reproduzem tais códigos de gênero e de sexualidade.

Estudar em uma escola pública e se tornar professora de História na mesma escola em uma pequena comunidade interiorana e tradicional conservadora é como enfrentar leões diariamente. 0 silêncio que nos é instituído não só enquanto alunos/as, mas também, e, principalmente, como docentes, haja vista que nos é tolhido em muitos momentos o direito de falarmos sobre determinados assuntos que provoquem espanto e que transgridam a fronteira da "normalidade".

Mas, não só a fala como também os corpos são silenciados, não devem se apresentar com determinados gestos, devem permanecer distantes e sem contato direto com alunos/as e funcionários/as da escola. Ora! Logo em uma escola, um lugar múltiplo, diverso, criativo?!. Mas, como já foi dito, a escola se trata de um espaço intelectual centrado na cabeça pensante, já o corpo deve ser contido, pois é o lugar em que se encontram as emoções, as sensibilidades, a libido. Assim, mostra a episteme ocidental.

Um corpo disciplinado pela escola é treinado no silêncio e num determinado modelo de fala; concebe e usa o tempo e o espaço de uma forma particular. Mãos, olhos e ouvidos estão adestrados para tarefas intelectuais, mas possivelmente desatentos ou desajeitados para outras tantas (grifo nosso) (LOURO, 2007, p. 21).

A disciplinarização dos corpos começa desde o próprio fardamento diferenciado para homens e para mulheres. Mas, não só caminha nessa distinção de gênero, o fardamento é a escola para além dos muros, é o panóptico na rua durante o caminho de volta para casa, é o fato da mulher vestir saia e precisar cruzar suas pernas, é manter-se composta e sem demonstrações extravagantes de algumas partes do seu corpo.

Por outro lado, na escola também aprendemos burlar a vigilância que nos persegue, que conseguimos com algumas pequenas revoltas diárias, mudando valores e regras. Como nos mostra Louro (2007, p. 9) para termos uma melhor compreensão sobre:

Lembro-me de ouvir, sempre, a mensagem de que, vestidas com o uniforme da escola, nós "éramos a escola!". Isso implicava a obrigação de manter um comportamento "adequado", respeitoso e apropriado, em qualquer lugar, a qualquer momento. 0 uniforme - saia azul pregueada e blusa branca com um laço azulmarinho - era, ao mesmo tempo, cobiçado por ser distintivo da instituição e desvirtuado por pequenas transgressões. A saia, mantida num comprimento

"decente" no interior da escola, era suspendida ao sair dali, enrolada na cintura de forma a conseguir um estilo "mini", mais condizente com a moda; o laço descia (do botão mais alto da blusa rente à gola onde deveria estar) alguns centímetros, de forma a proporcionar um decote mais atraente (o número de botões dependia da ousadia de cada uma).

Ou seja, o poder que nos vigia é o mesmo que nos instiga a (re)inventarmos cotidianamente os códigos que nos foram direcionados. Assim, nos (re)inventamos mulheres, negras, brancas, cristãs, umbandistas, solteiras, lésbicas etc., homens, heterossexuals, homossexuais, negros, gordos etc., é na escola onde se constrói a pluralidade, e é esse o discurso que deve permeá-la. 0 discurso que permita a possibilidade da diversidade, da liberdade de cada um/a possuir suas idiossincrasias, portanto, diferenças. 
No entanto, como citamos anteriormente, falar sobre determinadas coisas e saberes pode significar e até significa "perigo" ao "regime de verdade" no qual uma sociedade se ergue, ou seja, não possuímos o direito de falar tudo, ou melhor, de qualquer coisa, pois alguns discursos são excluídos por sua "periculosidade moral". Foucault, nos apresenta como os discursos atingidos por certas interdições revelam a sua ligação com o desejo e com o poder.

(...) em toda sociedade a produção do discurso é ao mesmo tempo controlada, selecionada, organizada e redistribuída por certo número de procedimentos que têm por função conjurar seus poderes e perigos, dominar seu acontecimento aleatório, esquivar sua pesada e temível materialidade. Em uma sociedade como a nossa, conhecemos, é certo, procedimentos de exclusão. 0 mais evidente, o mais familiar também, é a interdição. Sabe-se bem que não se tem o direito de dizer tudo, que não se pode falar de tudo em qualquer circunstância, que qualquer um, enfim, não pode falar qualquer coisa (FOUCAULT, 2009, p. 09).

Atentamos para o fato de que a exclusão de determinados conteúdos discursivos na escola não partem apenas da representação administrativa institucional, mas das micror- relações presentes naquele espaço, inclusive, entre docentes, discentes, família e funcionários em geral da escola. Nesse sentido, constatamos que os temas transversais sobre gênero e sobre sexualidade quase nunca são analisados na escola e quando analisados por algum/a docente, sempre surgem comentários do tipo: "Já estão querendo incitar os/as jovens a 'virarem' gays" ou "Agora não existe mais mulher e nem homem, é tudo igual, é tudo a mesma coisa”. Desse modo, parece até impossível fugir da naturalização dos papéis de gênero e das orientações sexuais. Já, como consta nos Parâmetros Curriculares Nacionais:

[...] os objetivos e conteúdos dos Temas Transversais devem ser incorporados nas áreas já existentes e no trabalho educativo da escola. É essa forma de organizar o trabalho didático que recebeu o nome de transversalidade (PCN's, 1998, p. 18).

No entanto, essa não inserção dos temas transversais diretamente na grade curricular definida pelo Ministério da Educação (MEC) deixa a cargo do planejamento escolar com o Plano Político Pedagógico (PPP) em poder contemplar discussões fundamentais para inibir as discriminações presentes não só no interior do espaço escolar com a prática do bullying, mas em toda a sociedade. Como é possível diminuir os preconceitos, as discriminações e, consequentemente, as várias violências, trabalhando as questões de gênero e de sexualidade na escola? Bem, ao mostrarmos que não nascemos homens e nem mulheres, nem tampouco heterossexual, e que esses códigos não são inerentes a nós, nos colocamos como constructos sociais, que foram direcionados/as a ocupar determinados espaços, bem como, designados/as a determinadas características na sociedade, inclusive, no que tange à sexualidade.

Nesse sentido, mostramos que somos contingentes, ou seja, construídos/as histórica e culturalmente ao longo das nossas vidas, o que independe das questões biológicas. Isso contraria, de certo modo, a própria ideia binária presente tanto no gênero quanto na sexualidade, mantida e justificada por discursos biologizantes. Assim, temos que ao romper com as determinadas dicotomias, estaremos permitindo a pluralidade e a singularidade de que cada um/a se expressem, mas não de forma hierárquica e dualista.

Portanto, mesmo com a necessidade de debater sobre gênero e sobre sexualidade ainda presenciamos de uma enorme lacuna acerca dessas questões. Certa vez, ficamos responsáveis para conduzir o Projeto Político Pedagógico da instituição de ensino na qual lecionávamos e procuramos enfatizar as questões de gênero e de sexualidade na mesma instituição, pois achávamos necessário para uma escola cujo cotidiano são ações de violência e xingamentos com relação às pessoas com orientações sexuais que não se enquadram na heteronormatividade, como também, são direcionados a meninas e aos meninos que não se apresentam no modelo padrão do gênero, branco, cristão, burguês.

As críticas surgiram. Mas, não desistimos e realizamos uma palestra com o seguinte tema: "Papéis sociais de homens e de mulheres e sexualidade", contando com a presença de discentes, de docentes e de pessoas da comunidade interessadas na temática. Posteriormente, alguns/mas alunos/as nos procuraram para falar sobre suas subjetividades e expressar o que de fato sentiam e como se reprimiam e se violentavam todos os dias em qualquer espaço por onde caminhasse. Assim, atuamos como psicólogas para ouvir esses/as jovens e seus dramas diários. Jovens que foram violentados/as ou ameaçados/as pelos pais por expressarem sua sexualidade, filhas expulsas de casa e/ou proibidas de manter contato com outras amigas, entre tantos outros relatos, que não gravamos e sequer transcrevemos, mas que seriam importantes para esse estudo, encontramos jovens que vivem angustiados/as por estarem inseridos/as 
em uma sociedade machista, lesbohomotransfóbica, racista, cristocêntrica, burguesa, e que não podem apresentar suas idiossincrasias se sujeitando aos padrões morais dicotômicos. E, sofrem por sentirem o peso de ter seu direito de liberdade tolhido.

O fato de relatar essas experiências que discentes compartilharam após a palestra, nos fez perceber o quanto aqueles/as são violentados/as cotidianamente. Esquecemos que preconceito e discriminação são manifestações de violência, que mesmo não se apresentando fisicamente, apunhalam o/a indivíduo/a e o joga no espaço da exclusão e da marginalidade.

Na escola lidamos dia após dia com vários tipos de preconceitos e de discriminações, com práticas de bullying que não partem apenas de alunos/as, mas também de professores/as e dos demais profissionais. No entanto, as práticas envolvidas pelos discursos da heteronormatividade são mais intensas e presentes no cotidiano escolar. Lembramos de um menino com jeito efeminado, que foi reivindicar uma melhoria para a escola, que ao se expressar recebeu a seguinte frase de uma professora: "Vai virar homem!", colocando-o em uma situação constrangedora frente aos demais estudantes, professores/as e funcionários/as.

Alguns estudos realizados, relatam experiências parecidas, ao mesmo tempo que constatam o que acabamos de citar, pois, no âmbito escolar existe também uma

"hierarquização das diferenças":

[...] as deficiências físicas e mentais eram mais toleradas, tanto por alunos, como pelos profissionais de ensino (não presenciei nenhuma discriminação nesse sentido); a diferença étnico-racial gerava situações de discriminação, algumas vezes não combatidas por professores, mas nunca por eles protagonizadas; $a$ diferença de gênero, que inclui aqui determinadas expectativas de comportamento feminino e masculino, assim como a orientação sexual, configuravase para a pesquisa como a mais problemática, na medida em que não apenas era mais frequentemente discriminada, como também era a menos amparada pelos adultos, que, diversas vezes, se envolveram nessas situações de discriminação (grifo nosso) (LEITE, 2011, p. 11).

Assim, podemos observar como se constitui a naturalização da sexualidade enquanto heteronormativa. Constrói-se nas minúcias das relações de poderes, por meio de discursos, dispositivos e silenciamentos que mantêm a dualidade maniqueísta do que é considerado como "bom", "normal", "natural" em contrapartida ao que se considera enquanto "ruim", "anormal", "patológico". Desse modo, o que presenciamos repassados nas práticas de homofobia e/ou de bullying, são discursos naturalizantes das identidades hétero, cristã, burguesa e branca, que não respeitam as diferenças, os processos históricos e a heterogeneidade presente na vida social, ou seja,

[...] em nossa sociedade, a norma que se estabelece, historicamente, remete ao homem branco, heterossexual, de classe média urbana e cristão e essa passa a ser a referência que não precisa mais ser nomeada. Serão os "outros" sujeitos sociais que se tornarão "marcados", que se definirão e serão denominados a partir dessa referência. Desta forma, a mulher é representada como "o segundo sexo" e gays e lésbicas são descritos como desviantes da norma heterossexual (LOURO, 2007, p. 15).

Os múltiplos discursos sobre sexo e sexualidade foram normatizados historicamente, instaurando saberes e instituindo verdades incontestáveis, pois questionar era e ainda é se colocar como o/a outro/a pervertido/a e transgressor/a dos papéis morais que lhes foram atribuídos. Mas, afinal, o que entendemos enquanto heteronormatividade, cujo conceito pode não ser tão conhecido, mas suas consequências são sentidas? Nesse sentido, explicamos que

[...] por heteronormatividade entende-se a regulação do sexo, do gênero, do desejo e das práticas sexuais nas categorias binárias masculino e feminino, distintas, complementares e hierarquizadas. Define, desse modo, a estética, os comportamentos e os papéis sociais aceitáveis para cada gênero, em lógica dicotômica que marginaliza os que se desviam de qualquer desses padrões (grifo nosso) (LEITE, 2011, p. 14). 
Desse modo, ocorre a universalização de uma orientação sexual e ao mesmo tempo a sua naturalização binária, sendo determinada para todos/as os/as sujeitos/as em todos os espaços.

No entanto, vocês podem se perguntar: Como falarmos em naturalização, tendo em vista a frase pronunciada pela professora: "Vai virar homem!"? Pois, sabemos que quando falamos em naturalização consideramos que existe uma "essência", imutável, fixa e estável em cada ser. Mas, essa frase nos leva a inferir que a professora corrobora com a ideia de que mesmo tendendo a outras orientações sexuais que não a heterossexualidade, tem que se voltar ao que se considera hegemônica em nossa sociedade, indiscutivelmente, a heteronormatividade.

Por sua vez, esses discursos já violentos culminam em contribuir com a violência e a prática da homofobia, pois se elege uma forma superior de se atuar na sociedade, construindo pensamentos e ideais de repressões para a docilização dos corpos que não se enquadram no modelo aceito socialmente e se configuram como os/as "outros/as".

Para uma maior inteligibilidade sobre o assunto, Louro $(1997$, p. 27) nos apresenta um estudo realizado por Deborah Britzman (1996), a qual diz:

Nenhuma identidade sexual - mesmo a mais normativa - é automática, autêntica, facilmente assumida; nenhuma identidade sexual existe sem negociação ou construção. Não existe, de um lado, uma identidade heterossexual lá fora, pronta, acabada, esperando para ser assumida e, de outro, uma identidade homossexual instável, que deve se virar sozinha. Em vez disso, toda identidade sexual é um constructo instável, mutável e volátil, uma relação social contraditória e não finalizada (grifos da autora).

Interessante percebermos que ao apontar a possibilidade da instabilidade e da mutabilidade da identidade sexual, indicamos a possibilidade da pluralidade sexual e de gênero, permitindo a percepção de que estas são contingentes e que, portanto, podem ser descontruídas "tais como" foram construídas. Consequentemente, essa desconstrução permite também, romper com a lógica dicotômica na qual se ergueram e se universalizaram o gênero e a sexualidade hegemônicas ocidentais.

0 processo desconstrutivo permite perturbar essa ideia de relação de via única e observar que o poder se exerce em várias direções. 0 exercício do poder pode, na verdade, fraturar e dividir internamente cada termo da oposição. Os sujeitos que constituem a dicotomia não são, de fato, apenas homens e mulheres, mas homens e mulheres de várias classes, raças, religiões, idades etc. e suas solidariedades e antagonismos podem provocar os arranjos mais diversos, perturbando a noção simplista e reduzida de "homem dominante versus mulher dominada". Por outro lado, não custa reafirmar que os grupos dominados são, muitas vezes, capazes de fazer dos espaços e das instâncias de opressão, lugares de resistência e de exercício de poder (Idem, p. 33).

Desse modo, os grupos considerados subordinados contestam a normalidade e a hegemonia de identidades ditas como normais, questionando seu caráter natural e universal, criam movimentos sociais e realizam mobilizações que contrariam os discursos que nos são predeterminados como inatos. Assim, os próprios movimentos Feministas e LGBT's realizam um trabalho que a própria instância escolar deveria realizar, o de desnaturalizar os gêneros "homem e mulher" e apresentar as possibilidades de se tornar "homens e mulheres" plurais ou mesmo não se tornar nenhum/a. Deve também, apresentar as pluralidades sexuais sem banalizá-las e/ou ridicularizá-las. Mas, é como falamos anteriormente, isso tem que partir principalmente dos docentes que se permitam a introduzir a Filosofia da Diferença nas escolas, permitindo conceder a liberdade para cada pessoa ser o que é e/ou o que quiser se tornar, pois não somos nada, mas sempre estamos querendo ser e/ou nos tornar alguma coisa.

No entanto, sabemos que os/as professores/as estão no meio de uma rede discursiva que os/as permeiam e os/as disciplinam de acordo com a ideia da centralização das identidades. De acordo com essa teia disciplinar:

[...] os professores devem evitar, portanto, práticas-discursos que essencializem categorias de desvio nas mentes dos estudantes, assim como nas suas próprias, discursos- práticas que fazem com que os estudantes internalizem e monitorem seu status desviante - na verdade, culpando a si próprios por sua marginalidade (PIGNATELLI, 2010, p. 137-138). 
Sabemos que não é uma tarefa fácil para nós educadores/as rompermos com determinados padrões já predeterminados em nossa sociedade, questionar valores cristalizados e identidades consideradas naturais. Mas, o que estamos tentando dizer é que a escola deve se preparar para as necessidades da sociedade hodierna e não limitar seus/suas indivíduos/as a um padrão de ser, reproduzindo os binarismos que preconizam os preconceitos, as discriminações e as diversas violências para com os grupos caracterizados como os/as "outros/as".

Assim, Pignatelli (p. 136) ressalta a importância do pensamento foucaultiano para ficarmos atentos/as às questões que nos constituem enquanto seres políticos e sociais, que atuam numa sociedade discursivamente construída por e em um "regime de verdade".

Foucault quer, sim, preservar a possibilidade da agência e de poder ser de outra forma, de ir contra uma vida construída através de (e regulada por) um modo normalizador de prática-discurso. Mas, frente a uma forma de governo que continua presa no envoltório naturalista do cotidiano e do obstinadamente invisível, ele também quer que estejamos conscientes das consequências da nossa escolha de permanecermos silenciosos e desatentos (PIGNATELLI, no prelo).

Para Foucault, a prática da liberdade envolve tanto um engajamento crítico "interno" das práticas autoconstitutivas quanto um questionamento "externo" das condições nas quais o eu é constituído, um contínuo desafio individual e coletivo para construir alternativas. À luz dos compromissos epistemológicos, políticos e éticos que os professores assumem para moldar aquilo que eles fazem $e$ a forma como eles pensam sobre o que eles fazem (e os efeitos bastante reais que aqueles compromissos têm nas vidas de seus estudantes e nas outras pessoas), um projeto vital de agência docente não pode se dar ao luxo de permanecer desatento a essas preocupações (grifo nosso) (Idem, p. 136).

Portanto, devemos ter o cuidado para não continuarmos a tolher dos/as nossos/as alunos/as suas capacidades e possibilidades outras que não aquelas que constroem as identidades defendidas hegemonicamente em nossa sociedade. Devemos antes de tudo realizar algumas perguntas para podermos praticar a Filosofia da Diferença e respeitar as singularidades de cada um/a: "O que fazemos com nós mesmos/as e com os/as outros/as para nos tornamos o que somos e o que os/as outros/as são"?

\section{CONSIDERAÇÕES FINAIS}

Inferimos que as questões de gênero estão presentes em todas as relações de poderes nos mais variados espaços da sociedade, transmitindo discursivamente valores e significados culturais que demarcam formas simbólicas para o "ser homem" e o "ser mulher". Muito embora, os papéis sociais do gênero resultem da construção histórica, parece até inconcebível questionarmos tais papéis, que cotidianamente são naturalizados por meio das teias discursivas e de poderes que permeiam as instâncias sociais.

Portanto, para refletirmos sobre as possíveis desconstruções e desnaturalizações desses papéis, partimos de uma instituição social significativa para isso, a escola, já que a consideramos como um forte mecanismo epistemológico social. Nesse sentido, além de privilegiarmos as relações de gênero presentes nesse espaço educacional, consideramos que a sexualidade também é determinada a partir do gênero, até porque, ao se construir o "sujeito homem" e o "sujeito mulher" de forma universalizante também se instituem as orientações sexuais e desejantes destes/as, reproduzindo uma heteronormatividade que contraria a ideia das diferenças e institui padrões de relacionamento para os/as indivíduos/as dentro de uma lógica binária hierárquica e dualista dos gêneros, que se construiu historicamente no Ocidente.

Para tanto, relatamos algumas experiências com relação às questões de gênero e de sexualidade, envolvendo tanto discentes quanto docentes vivenciadas no interior de uma escola. Por sua vez, para entendermos essas relações fizemos uso dos estudos foucaultianos auxiliados com Guacira Lopes Louro, que nos permitiu maior inteligibilidade acerca dessas experiências pedagógicas, abordando as análises discursivas, as relações de poder e as tecnologias de autogovernamentalidade propagadas pelo "poder disciplinar", bem como, a capacidade de resistência e questionamentos dos grupos que são considerados "anormais", ou seja, os/as outros/as. 
Por sua vez, o gênero e a sexualidade estão inseridos como temas transversais nos Programas Curriculares Nacionais (PCN's), porém, ainda existe uma ausência enorme acerca dessas discussões nas instituições escolares, propiciada até mesmo pela falta de preparo dos/as educadores/as para tratar de temas polêmicos que envolvem ambas as temáticas. Para tanto, propomos reflexões, debates e práticas de respeito pautadas na Filosofia da Diferença com vistas ao fortalecimento de implementações de políticas públicas para as mulheres e para a população LGBT, que tiveram seus direitos alijados ao longo da história.

Contudo, enfatizamos a necessidade de praticar a desnaturalização e a desconstrução dos papéis de gênero e de sexualidade, propondo uma maior diversidade de discussões nas escolas referentes a essas questões, pois a sociedade atual respira a pluralidade e a necessidade de políticas públicas que garantam o respeito às diferenças e às singularidades de cada pessoa. Não podemos mais caminhar na ideia dicotômica do que pode e deve ser considerado como normal, pois as relações de poderes e as práticas humanas ultrapassam qualquer enquadramento moral com relação às maneiras de ser de cada pessoa.

\section{REFERÊNCIAS}

[1] Artières, Philippe. O Intelectual específico. Dizer a atualidade: o trabalho de diagnóstico em Michel Foucault. In.: GROS, Frédéric (Org.). Foucault: a coragem da verdade. São Paulo: Parábola Editorial, 2004. pp. 15 - 37.

[2] Brasil. Parâmetros curriculares nacionais: terceiro e quarto ciclos: apresentação dos temastransversais / Secretaria de Educação Fundamental. - Brasília: MEC/SEF, 1998.

[3] Donna Wilshire. Os usos do mito, da imagem e do corpo da mulher na re-imaginação do conhecimento. In: JAGGAR, Alisson M.; BORDO, Susan R. (Org.). Gênero, corpo, conhecimento. Rio de Janeiro: Record: Rosa dos Tempos, 1997. p. 101-125.

[4] Foucault, Michel. Microfísica do poder. Rio de Janeiro: Edições Graal, 1979.

[5] ___ História da Sexualidade 2: o uso dos prazeres. Rio de Janeiro: Edições Graal, 1984. ___. A ordem do discurso: aula inaugural no College de France, pronunciada em 2 de dezembro de 1970. 19. ed. São Paulo: Edições Loyola, 2009.

[6] Gonçalves, Andréa Lisly. História e Gênero. Belo Horizonte: Autêntica, 2006.

[7] Gore, Jennifer M. Foucault e Educação: Fascinantes Desafios. In: Silva, Tomaz Tadeu (Org.). 0 Sujeito da Educação: Estudos Foucaultianos. 7. ed. - Petrópolis, RJ: Vozes, 2010. p. 09-20.

[8] Leite, Mirian S. Significação da violência e heteronormatividade no contexto da prática curricular. In: Revista e-curriculum. ISSN: 1809-3876. Disponível em: <http://www.bibliotecadigital.unicamp.br/document/?code=000851942\&fd=y>. Acesso em: 18 ago. 2013.

[9] Louro, Guacira Lopes. Gênero, sexualidade e educação. Uma perspectiva pósestruturalista. Petrópolis, RJ: Vozes, 1997.

[10] _ _ (Org.). 0 corpo educado: pedagogias da sexualidade. Belo Horizonte: Autêntica, 2007.

[11] Mariano, Silvana Aparecida. O sujeito do feminismo e o pós-estruturalismo. In: Revista: Estudos Feministas. Florianópolis: 2005.

[12] Peters, Michael. Pós-estruturalismo e filosofia da diferença. Belo Horizonte: Autêntica, 2000.

[13] Pignatelli, Frank. Que posso fazer? Foucault e a questão da liberdade e da agência docente. In: Silva, Tomaz Tadeu (Org.). 0 Sujeito da Educação: Estudos Foucaultianos. 7. ed. - Petrópolis, RJ: Vozes, 2010. p. 127-154. 


\section{Capítulo 2}

O discursos sobre gênero no espaço escolar: Configurando identidades a partir de referências normatizadas

Arthur Furtado Bogéa

Iran de Maria Leitão Nunes

João Antônio de Sousa Lira

Resumo: Este trabalho constitui-se em um estudo sobre a categoria analítica gênero e a atuação dos discursos referentes a ela no espaço escolar. A partir de estudos bibliográficos, analisa-se o gênero como construção social produzida discursivamente no e pelo processo histórico-político de constituição da sociedade, rompendo-se com a visão de gênero como efeito de uma essência da constituição biológica dos sujeitos. Parte-se do pressuposto de que a escola atua na constituição das identidades de gênero, uma vez que estas são configuradas a partir de uma serie de discursos presentes em contextos específicos do e no processo de socialização e nessa atuação, a escola normatiza e legitima as referências de gênero atribuídas aos sujeitos como processo meramente biológico por estar inserida em um contexto social que significou o gênero como pertencente a natureza. Portanto, concluímos que a escola não pode usar o discurso de neutralidade, pois a sua atuação nunca será neutra, mas deve rever os seus discursos buscando desconstruir um olhar que exclui e pune os diferentes. Ultilizou-se como principais aportes teóricos Boudieu e Passeron (1982), Butler $(2003,2000)$, Foucault (1996), Louro (2007), Nicholson (2000), Scott (1990), dentre outros.

Palavras-chave: Gênero. Discurso. Escola. 


\section{INTRODUÇÃO}

Neste trabalho, buscamos fazer um estudo teórico que tem por base uma abordagem pós-estruturalista e seus desdobramentos na teoria queer. A partir de estudos bibliograficos fizemos uma investigação sobre como são configurados elementos constitutivos de referências normativas de gênero a partir de discursos (re)produzidos na e pela escola.

Nas análises aqui realizadas, trabalhamos com a ideia de que gênero é uma forma discursiva/cultural de se produzir corpos sexuados considerados naturais e pré-discursivos. Focaliza-se o gênero como produção discursiva histórico-política e não como uma produção derivada de um sexo biológico (Butler, 2003).

A escola é tida, por algumas visões, como o meio de promover a inclusão de todos os sujeitos no processo de aprendizagem e colocá-los como membros ativos no sistema democrático social através da transmissão de valores éticos e morais, porém, não só a escola, mas todo o sistema que compõe o ensino pode ser entendido como ferramentas que servem para a manutenção dos paradigmas sociais estabelecidos, pois passa por cima ou exclui os diferentes e neutraliza as diferenças (Boudieu \& Passeron, 1982).

Nesse caso, os discursos que atuam no espaço escolar podem estar a serviço da manutenção de uma estrutura normativa de gênero ao colocá-lo como uma produto da natureza, pois se pensarmos o gênero como uma produção discursiva, poderá se compreender como as relações sociais constituem os papéis sociais outorgados aos sujeitos, tendo o gênero atribuído a eles como referência primeira e fundamental, como afirma Louro (2007) ao falar que o corpo é a materialização do discurso normativo, uma vez que a sociedade impõe de forma consciente e inconsciente as suas regras, valores, normas e condutas constituídas como padrão de normalidade aceito.

A norma constituída aos gêneros prescreve que estaríamos "destinados" à heterossexualidade e integrados a um esquema de classificação binária em que se separam de modo oposto e complementar às atribuições constitutivas de masculinidade e feminilidade. Foucault (1996) argumenta que os discursos produzem e reproduzem valores na sociedade e com isso permitem compreender que os discursos a respeito da referência normativa do gênero e de suas identidades, criam e sustentam um imaginário social de que esta referência possui o caráter de natural e assim se tem a "imposição" desta norma como "correta" a ser seguida.

Nesse sentido, a partir da naturalização de uma norma para as experiências do gênero, outras expressões possíveis de vivência das identidades são subordinadas e/ou excluídas. Butler (2003) destaca que a matriz normativa do gênero está referenciada na suposição da existência de um gênero inteligível, assim o sujeito que nascer com determinado órgão genital, deverá ter comportamentos e desejos determinados. No entanto, essa inteligibilidade do gênero segue a lógica das práticas reguladoras das relações sociais produzidas discursivamente em um processo histórico-político. 0 discurso se torna a chave para que o sujeito acesse e incorpore a ordem simbólica, a norma a respeito da forma como deve ser às experiências das identidades de gênero atribuídas aos sujeitos como natural.

Portanto, este trabalho busca compreender alguns dos elementos constitutivos dos atributos normativos da divisão binária do gênero fazendo uma análise das principais questões que o envolvem, bem como das discussões a respeito do discurso e de como ele constrói o gênero, pois segundo Scott (1990), o gênero pode ser uma categoria útil de análise, que nos auxilia a desvendar relações de poder. Busca-se, também, mostrar como os discursos escolares influenciam na construção das identidades de gênero dos sujeitos e assim, nos permite entender as representações sociais configuradas para as identidades de gênero e como os sujeitos constituem no cotidiano essas representações.

Diante do cenário atual, no qual se vê as estruturas normativas do gênero sendo fortalecidas e legitimadas pelos discursos políticos, jurídicos, religiosos, etc., a importância deste trabalho se reflete na tentativa de desconstruir uma visão naturalizada a respeito do gênero, uma vez que a matriz binária reproduz a referência de gênero como única. As questões relacionadas ao gênero como produção discursiva não são apreendidas pelos sujeitos, os quais não se percebem envolvidos em um processo contínuo de produção e reprodução das identidades de gênero.

\section{NOTAS SOBRE OS DISCURSOS ESCOLARES E A (RE)PRODUÇÃO NORMATIVA DE REFERÊNCIAS DE GÊNERO}

A educação escolar no decurso da formação histórica-política da sociedade vem atuando como um dos meios de difusão dos saberes sociais, bem como dos modos de vida, códigos simbólicos, estruturas organizacionais e valores sociais. Segundo a Lei de Diretrizes e Bases da Educação Nacional - LDB, "o 
ensino será ministrado com base nos seguintes princípios: vinculação entre educação escolar, o trabalho e as práticas sociais" (LDB, Art. 3ํㅡ, XI). Nesse sentido, a escola deveria promover ações por meio de processos educativos que despertassem nos indivíduos, nas entidades e nos grupos sociais o compromisso social. Assim, a escola deveria preparar e formar os alunos para serem cidadãos portadores de uma nova visão de mundo, tendo-se em vista as múltilas formas de experienciar a vida em sociedade.

Gadotti (2001) defende que nessa multiplicidade que é a vida e as experiências em sociedade, se torna um ato pedagógico desvelar as contradições existentes e evidenciá-las com vista à sua superação. Não cabe ao educador criar contradições e conflitos, mas é seu papel revelá-los e tirar os sujeitos da inconsciência. 0 papel da educação, da escola e do educador é um papel político.

Para Paulo Freire (1996), a escola tem um papel bem mais amplo do que simplesmente passar conteúdos: ensinar exige compreender que a educação é uma forma de intervenção no mundo. Desse modo, cabe à escola aceitar e refletir sobre as diferenças, pois uma das fundamentais vias de transformação social é proveniente do processo educacional.

No entanto, a escola, além de ensinar conteúdos pré-estabelecidos por um currículo formal, ensina através de sutis e profundas imposições que os alunos devem aprender a ter corpos dóceis, a obedecer, a pedir licença, a fazer tudo de acordo com o conjunto de regras estabelecido pelas normas escolares. Assim, é a partir do não fazer que os alunos devem aprender a se enquadrarem nas normas sociais.

A escola em muitas de suas ações ignora as múltiplas e dinamicas identidades de seus alunos, dentre elas as identidades de gênero e sexualidades, e coloca esses alunos em um espaço no qual não cabe a forma como eles se significam. Nesse caso, a não discussão, o silenciamento, o ocultamento e a tentativa de adestramento de diversas composições identitárias, sexuais, de desejos e subjetividades são formas de violência que marcam profundamente as experiências e os corpos desses sujeitos.

[...] podemos pensar que os processos de silêncio e silenciamento ocorrem em diferentes dimensões: para calar os alunos diante da necessidade de uma explicação, para colocar em vigor um entendimento da disciplina e controle de turma, mas também para silenciar práticas, assuntos e comportamentos tidos como indesejáveis e não valorizados (Ferrari, 2011, p. 92).

Nesse sentido, a escola é um dos mecanismos principais no processo de produção e reprodução de referências de gênero. Scott (1990) aponta que os conceitos de gênero servem para estruturar a percepção e a organização de toda a vida em sociedade. Essas estruturas servem para a construção, legitimação e distribuição de poder, sendo que é através dos discursos que se criam essas estruturas normativas como forma de manutenção dessas relações de poder e os discursos escolares não estão isentos dessas relações.

Em vista disso, pela forma como está constituída, a escola pode inclina-se a reproduzir uma ideologia social configurada por discursos especializados a respeito da existência de um "normal/natural". Chauí (2016, p. 247) define essa ideologia como "um corpus de representações e de normas que fixam e prescrevem de antemão o que se deve e como se deve pensar, agir e sentir".

Essa ideologia é construída pelos discursos, pois, segundo Foucault (1996), a partir dos discursos bioquímicos, psiquiátricos e outros correlatos, se instaurou o "sexo" como substrato orgânico de uma referência padrão de identidade de gênero, o que gera uma interpretação naturalizada em meio as relações sociais.

Gênero foi desenvolvido e usado como oposição ao sexo. (Nicholson, 2000). 0 sistema sexo/gênero tornou-se usual, não só no senso comum, como nos estudos de gênero. Essa distinção entende que o sexo seria compreendido como a representação da conformação biológica daquilo que seria naturalmente dado, enquanto gênero representaria o que é socialmente construído, os significados e símbolos moldados ao longo da história.

Foucault (1996) diz que todo discurso é uma forma de impor a verdade aos que ouvem. Esses discursos que possuíam o poder de verdade naturalizaram o sexo e o configuraram como determinante do gênero, assim os dois polos passaram a possuir uma "natureza" inicial.

A distinção que coloca o sexo como natural e gênero como cultural, com o segundo sendo significado a partir das características do primeiro, acaba por localizar o gênero como uma produção de base natural e não como o resultado de discursos históricos e políticos que buscavam determinar verdades.

Butler (2003) diz que tanto sexo quanto gênero são formas de conhecimentos construídos historicamente e politicamente a respeito dos corpos, das diferenças sexuais e da sexualidade. Entretanto, os significados 
construídos a respeito do sexo foram naturalizados e entendê-lo como uma essência da natureza o coloca em uma condição pré-cultural e pré-discursiva, ou seja, se o sexo está antes da cultura e da nomeação pelo discurso, ele seria uma categoria a-histórica.

Destarte, o sexo e o gênero são verdades construídas, sendo que aquilo que se configurou como seus significados são marcados e formados por práticas discursivas. (Butler, 2000). Desta maneira, se o sexo e o gênero são verdades construídas discursivamente sobre eles, não se pode dizer que algum deles é natural, pois ambos só existem após serem significados. Todas as relações e configurações que os envolvem só ganham sentido depois de serem significadas culturalmente a partir de discursos construídos.

Se o gênero é a construção social do sexo e se não existe nenhum acesso a esse "sexo" exceto por meio de sua construção, então parece não apenas que o sexo é absorvido pelo gênero, mas que o "sexo" torna-se algo como uma ficção, talvez uma fantasia, retroativamente instalado em um local pré-linguístico ao qual não existe nenhum acesso direto (Butler, 2000, p. 157).

A interpretação naturalizada a respeito do gênero, faz com que os sujeitos sejam direcionados a comportamentos específicos constituídos como pertencentes ao gênero que socialmente se atribuiu a eles, a partir de suas características anatomo-biológicas. Louro (2007) observa que distintas estratégias procuram intervir sobre os agrupamentos humanos buscando maneiras para regular e controlar as relações de gênero.

No entanto, os sujeitos não são construídos apenas a partir de repressões e sanções, mas a partir de práticas e relações que internalizam gestos, modos de ser e estar no mundo, formas de falar e agir, condutas e posturas corporais. Portanto, os gêneros se produzem nas e pelas relações de poder.

Essas relações de poder estão presentes nas escolas, através dos currículos, dos livros didáticos, da relação aluno com aluno, aluno com professor, da relação professor e normas regulamentares de sua atuação, das políticas educacionais, etc., e estão normatizando a todo momento qualquer possível desvio da norma. Desse modo, na escola "transitam modelos de gêneros nos currículos e estes projetam a heterossexualidade e a masculinidade hegemônicas como norma e referência." (Caetano, 2013, p.67).

Em vista disso, Butler (2003) destaca que o gênero é outorgado aos sujeitos tendo como base uma referência anatomo-biológica que coloca os órgãos genitais como determinantes, pois estes carregariam em si uma essência natural para definir as identidades dos sujeitos. Sendo assim, as identidades de gênero seriam uma forma de materialização dos discursos normativos a respeito do gênero. Nesse sentido, que "quando fazemos falar o silêncio que sustenta a ideologia, produzimos um outro discurso, o contradiscurso da ideologia, pois o silêncio, ao ser falado, destrói o discurso que silenciava". (CHAUÍ, 2016, p. 247).

Dessa forma, é necessário que a escola perceba quais os discursos estão silenciados a respeito do gênero e de suas possíveis experiências, pois a escola não pode se isentar desse debate, uma vez que ao usar o discurso de neutralidade a escola fortalece e legitima a ideologia dominante e exclui aqueles que não se significam dentro das referências dessa ideologia.

O silenciamento, nesse sentido, é um mecanismo social que serve para tornar ilegítima as experiências do outro e posicionar os sujeitos tidos como fora da norma em uma configuração que os significa para menos que inferior, quase inexistentes. 0 silêncio por si só não dizem muitas coisas, mas como silenciamento ou como este toma forma, promove uma série de discursos e atos corporais que muito diz sobre como a escola é moldada sobre padrões heteronormativos (Foucault, 1988). "O silêncio é a negação do reconhecimento e ambos formam parte de um ritual mais amplo de interpelação dos sujeitos e construção das subjetividades como algo que estamos constantemente sujeitos ou assujeitados." (Ferrari, 2011,p. 101).

Portanto, os discursos produzidos e reproduzidos na escola devem trazer a questão da multiplicidade dos gêneros e buscar a construção de uma perspectiva igualitária através do respeito ao diferente, uma vez que na conjuntura atual, a cada dia se torna mais presente nas relações sociais a multiplicidade dos gêneros experienciados pelos sujeitos e, nesse contexto, a escola não pode ficar alheia, pois possui o papel de produtora e reprodutora de conhecimentos (Bourdieu \& Passeron, 1982). Desse modo, é necessária uma discussão ampla a respeito de como a educação está lidando com essas novas demandas a respeito do gênero e da sexualidade, uma vez que outros espaços sociais abrem essa discussão e permitem, mesmo que de forma ainda muito tímida, um novo olhar a respeito do gênero.

As telenovelas, os filmes, as séries, os programas de tv, as músicas, etc., trazem essa temática no seu conteúdo. Quase todos os dias os jornais estão noticiando casos de violência por questões de gênero, são 
mulheres mortas pelos maridos, são gays espancados na rua, são travestis e transexuais espancadas até a morte, são garotos degolados simplesmente por serem "diferentes". A todo momento os sujeitos estão sendo vigiados por todos para não transgredirem as normas, pois, do contrário, os olhares punitivos, repressores e as sanções sociais vão tentar adequá-los ao "normal".

Daí a necessidade de se entender que a escola está atuando na formação de gênero dos sujeitos em processos discursivos que atuam a todo momento no espaço escolar e configura identidades hierarquizadas em relações de poder. Scott (1990) diz que o gênero pode ser uma categoria útil de análise, que nos auxilia a desvendar relações de poder. Assim, nos permite entender melhor as representações sociais configuradas para as identidades de gênero e como os sujeitos constituem no cotidiano essas representações.

As identidades de gênero, segundo Louro (2007), materializadas nos corpos, são efeitos de uma relação direta com aspectos comportamentais e as referências de corpos produzidas a partir da matriz normativa do gênero, assim como a internalização desses aspectos, são tidos como fundamentais para que os sujeitos sejam considerados pertencentes ao quadro de membros daquilo que foi constituído como "normal".

Portanto, trazer o entendimento do conceito de gênero e das principais questões que o envolvem para o espaço escolar é fundamental para se compreender como os discursos constroem os corpos normatizados. Isso é necessário no sentido de que a escola está inserida na (re)produção de uma norma social que tem como como referência de gênero a heteronormatividade. Segundo Miskolci (2009) a heteronormatividade funciona como um aparato de poder.

A heteronormatividade é um conjunto de prescrições que fundamenta processos sociais de regulação e controle, até mesmo aqueles que não se relacionam com pessoas do sexo oposto. Assim, ela não se refere apenas aos sujeitos legítimos e normalizados, mas é uma denominação contemporânea para o dispositivo histórico da sexualidade que evidencia seu objetivo: formar todos para serem heterossexuais ou organizarem suas vidas a partir do modelo supostamente coerente, superior e "natural" da heterossexualidade (Miskolci, 1996. p. 156).

Nesse contexto, a heteronormatividade pode ser pensada como a norma materializada nos corpos em um processo que visa disciplinar formas de masculinidades e feminilidades possíveis e diferentes entre si e a escola pode estar atuando como reprodutora desse aparato de poder que disciplina, pune e exclui sujeitos.

O corpo é um espaço politico, uma instância de relações de poder, espaço de constante vigilância e de pertencimento e exclusões. O corpo é fabricado, só sobrevivem e permanecem dentro de limites estabelecidos por esquemas reguladores com alto grau de generalização. (Butler, 2000). "[...] o corpo, lugar de dissolução do eu, volume em perpétua pulverização, traz consigo em sua vida e em sua morte, em sua força e em sua fraqueza a inscrição de todos os acontecimentos e conflitos, erros e desejos" (Foucault, 1979, p.22).

Sendo o corpo aquilo que os discursos construíram sobre ele ao longo do processo histórico-político de constituição das relações sociais, as configurações de gênero produzidas e reproduzidas pelos discursos escolares tendem a seguir esses padrões estabelecidos como "normais". No entanto, se o que se tem sobre as configurações do gênero são construtos históricos-políticos e, desse modo, não são naturais, a escola poderá questionar a sua legitimidade (Louro, 2007).

Consequentemente, sabemos que as questões de gênero estão presentes no cotidiano escolar, nas brincadeiras, jogos, grupos de alunos/as e professores/as, nas aulas e principalmente nos discursos que se constroem a partir de todos esses elementos, porém por serem constituídas como naturais essas questões podem passam despercebidas aos olhos de gestores/as, educadores/as, estudantes e pais de alunos. Ao que parece, o espaço escolar tenta colocar os sujeitos do gênero em quadros regulatórios e pune aqueles que não conseguem se enquadrar.

As múltiplas formas de experiência do gênero e de suas identidades (homossexualidade, bissexualidade, intersexualidade, transexualidade, etc.), o movimento LGBT, os movimentos feministas entre outros, têm contribuído profundamente para problematizar as questões de cunho político, social, cultural, científico, jurídico e educacional sobre os limites impostos a respeito das questões de gênero, além de romperem com o silêncio imposto por uma norma a respeito de como deve ser o corpo de homens e mulheres em um mundo constituído nos limites da heterossexualidade. 
É necessário que a escola e os discursos produzidos e reproduzidos em seu espaço possam ir além dos limites impostos pelas normas construídas pelos discursos institucionalizados a respeito do gênero. 0 papel da escola é fundamental para a construção de uma sociedade do conhecimento que transcenda aquilo que foi constituído como norma a ser seguida e que exclui da sociedade sujeitos que não se encaixam nos quadros regulatórios que são impostos.

\subsection{CONSIDERAÇÕES FINAIS}

Pensar o gênero a partir das configurações que constituem a nossa sociedade hoje, ainda é uma forma limitada de fazê-lo diante da amplitude de possibilidades de experiências que o envolvem. Assim, quando se pensa as identidades de gênero fora das estruturas que compõem a matriz normativa para as experiências, se está sujeito aos olhares de estranhamento e punitivos, uma vez que se têm as estruturas normativas como se fossem parte de uma essência natural do gênero e colocá-las como construções histórico-políticas seria perturbar a ordem natural.

A escola é parte dessas estruturas normativas, uma vez que em sua atuação ela tem papel fundamental na constituição dos sujeitos de gênero. Assim, não se pode pensar em uma escola isenta ou neutra em relação às discussões a respeito das questões de gênero, pois os seus usuários não deixam fora dos muros da escola suas individualidades e subjetividades. A multiplicidade social é materializada nas múltiplas personalidades dos alunos.

Nesse sentido, levando-se em consideração os aspectos apresentados, podemos afirmar que as questões que envolvem os gêneros estão relacionadas a significações construídas em discursos, lugares e tempos específicos. As identidades de gênero são formadas a partir dessas significações reproduzidas no meio social, ou seja, o gênero e suas identidades são construídos a partir de elementos presentes na constituição da sociedade. Os discursos escolares são parte nesse processo e tendem a reproduzir a referência social de gênero e de suas identidades.

Portanto, os discursos produzidos e reproduzidos no espaço escolar são instrumentos fundamentais na construção de identidades de gênero normatizadas, pois reproduzem as configurações impostas pela heteronormatividade que estão presentes na estrutura social. A atuação de professores, gestores, pais e dos próprios alunos segue a lógica imposta pela sociedade e dessa forma impõe uma norma aos sujeitos tidos como diferentes.

É fundamental que a escola reveja a sua atuação no que diz respeito a construção de um discurso que vise a desconstrução desse olhar que exclui e pune o diferente. A escola e seus discursos devem ajudar seus alunos a pensarem diferente e respeitarem o direito de liberdade de cada um, pois enquanto a escola atuar como reprodutora daquilo que é imposta como norma pela sociedade, ela não ajudará na diminuição das desigualdades, pré-conceitos, machismos, homofobia, violência e desrespeito.

\section{REFERÊNCIAS}

[1] Bourdieu, P. \& Passeron, J.-C. (1982). A reprodução: Elementos para uma teoria do sistema de ensino. Trad. de Reynaldo Bairão. Rio de Janeiro: Francisco Alves.

[2] Brasil. (1996) Lei de Diretrises e Bases da Educação Nacional - LDB Lei 9.394.

[3] Butler, Judith. (2000). Corpos que pesam: sobre os limites discursivos do 'sexo'. In: Louro, Guacira Lopes (org.). 0 corpo educado: pedagogias da sexualidade. Belo Horizonte: Autêntica. pp. 151-172.

[4] Butler, Judith. (2003). Problemas de gênero. Feminismo e subversão da identidade. Trad. Renato Aguiar. Ed. Civilização brasileira. Rio de Janeiro.

[5] Caetano, Marcio. (2013) Movimentos Curriculares e a construção da heteronormatividade. In: RODRIGUES, Alexandro; Barreto, Maria A. S. Correia (orgs). Currículos, gêneros e sexualidades. Experiências misturadas e compartilhadas. Vitoria: Edufes.

[6] Chauí, Marilena de Souza. (2016). Ideologia e educação. São Paulo: SP. Educação e Pesquisa. V. 42, n. 1, pp. 245-257.

[7] Ferrari, Anderson; Marques, Luciana Pacheco (orgs). (2011). Silêncios e Educação. Juiz de Fora: Ed. UFJF.

[8] Foucault, Michel. (1979). Microfísica do poder. Rio de Janeiro, RJ: Graal.

[9] Foucault, Michel. (1988). História da sexualidade I: a vontade de saber. Rio de Janeiro: Graal.

[10] Foucault, Michel. (1996). A ordem do discurso. São Paulo: Edições Loyola.

[11] Freire, Paulo. (1996). Pedagogia da Autonomia, São Paulo - SP, Paz e Terra.

[12] Gadotti, Moacir. (2001). Educação e Poder: Introdução a Pedagogia do Conflito, 12 edição - São Paulo, Cortez.

[13] Louro, G. L. (2007). O corpo educado. Pedagogias da sexualidade. Belo Horizonte. Editora Autêntica. 
[14] Miskolci, Richard. (2009). A teoria queer e a questão das diferenças: por uma analítica da normalização. Sociologias, Porto Alegre, ano 11, no 21, jan./jun. pp. 150-182.

[15] Nicholson, Linda. (2000). Interpretando o gênero. Tradução Luiz Felipe Guimarães Soares. Revista Estudos Feministas, 8 (2).

[16] Scott, Joan Wallach. (1990). Gênero: uma categoria útil de análise histórica. Educação e Realidade, Porto Alegre, n. 2, p. 5-22, jul./dez. 


\section{Capítulo 3}

\section{Literatura infantil como ferramenta de inclusão de modelos familiares homoparentais}

\section{Magdiel Júnior da Silva \\ Ana Paula Marques de Araújo \\ Tatiana Cristina Vasconcelos}

Resumo: 0 presente texto tem como objetivo discutir sobre a inclusão de famílias homoparentais no contexto da literatura infantil na perspectiva da inclusão social e respeito à diversidade. Para realizar esse trabalho foi primeiramente realizada uma revisão bibliográfica utilizando como aportes teóricos: ARGÜELLO(2005),ALVES et alia (2016), FOUCAULT (1975), DRESCH (2016), BITTAR (1993) COSTA et SANTOS (2016) e MEIRELES (1984),em seguida, foi desenvolvido um estudo de campo com abordagem qualitativa com a participação de graduandos em Letras (Inglês e Espanhol) que responderam um questionário sobre a literatura infantil e famílias homoparentais a partir da leituras dos livros infantis And tango makesthree e Nicolás tiene dos papás. Para estruturar o trabalho foi contextualizado o conceito de famíliae noções de identidade(s), bem como a representação da família homoparental nos livros paradidáticos infantis. Posteriormente, são analisados as opiniões dos professores em formação de cursos de línguas estrangeiras acerca da questão da diversidade de identidades de gênero e de família e como a mesma poderia ser trabalhada em sala de aula através da literatura infantil. Desse modo, a pesquisa contribui com a difusão de novas abordagens de ensino da literatura que incluam as múltiplas formas de visualizar a noção de família na sociedade.

Palavras-chave: Diversidade de gênero. Literatura Infantil. Língua Estrangeira. Família homoparental.

** Esse estudo foi apresentado originalmente no III Congresso Internacional de Educação Inclusiva \& III Jornada Chilena Brasileira de Educação Inclusiva e Direitos Humanos 


\section{INTRODUÇÃO}

O âmbito familiar é alvo de transformações ao longo da história, percebemos que há modificação na estrutura, conceito, costumes, comportamentos e organização hierárquica de papéis e de gênero. Deste modo, tendo conhecimento de que é a partir do âmbito família que a sociedade passa a organizar-se, temos o conhecimento de que é através dela em sua convivência que o indivíduo passa a ter seus primeiros ensinamentos de respeito e afetividade. Dentre as famílias, faremos uma análise nos livros de literatura infantil: Nicolás tiene dos papás e And tango makes three, os mesmos abordam a família homoparental, especificamente a constituída por pai e filho.

Propomos desconstruir discursos excludentes e promover uma reflexão sobre a necessidade de se representar na literatura infantil uma identidade de família homoparental. Frente a isso, se estrutura nossa discussão acerca deste universo singular, que cria suas próprias histórias, seus significados particulares, suas reproduções de relações de vida, valores, formas e opiniões. Diante disso, o presente texto objetivou discutir sobre a inclusão de famílias homoparentais no contexto da literatura infantil na perspectiva da inclusão social e respeito à diversidade.

\section{UMA BREVE APROXIMAÇÃO AO CONCEITO DE FAMÍLIA}

Os modelos familiares há séculos foram construídos por sociedades conservadoras em que a família só existe através do matrimônio entre pessoas de sexo distinto, e desse modo, não havia outra forma de constituição familiar que não fosse através deste modelo. Dresch (2016) afirma que "seguia os moldes patriarcais, era hierarquizada, patrimonializada com o homem gerindo a unidade de produção e seus membros correspondiam à força laboral, visando sempre o progresso da entidade familiar."

O Código Civil Brasileiro de 1916 aborda o tema família com mais abrangência, como também, o casamento civil entre homens e mulheres como sendo os responsáveis pela instituição familiar. Segundo Bittar (1993), o conceito de família se caracteriza "como sendo pessoas que possuem uma relação de consanguinidade, sendo nesse preceito envolvido todos aqueles que apresentam a mesma genética". Em 1988, por meio do art. 226, §3ํ da Constituição Federal, família pode ser definida como "base da sociedade, formada pela união entre homem e mulher". Já o estatuto da família afirma no Art. 2o que "define-se entidade familiar como o núcleo social formado a partir da união entre um homem e uma mulher, por meio de casamento ou união estável, ou ainda por comunidade formada por qualquer dos pais e seus descendentes". Dias (2009, p. 3apud DRESCH, 2016) diz que "a família, de um modo geral, sempre foi vista como sendo o centro da sociedade, a qual vem desenvolvendo sua função de acordo com a realidade de cada período, como pode ser visto pelos ensinamentos dos doutrinadores."

Ao longo dos anos, observa-se que o termo família passou por modificações conceituais, bem como estruturais no transcorrer do século XX, podemos inferir que a principal mudança foi na percepção pela sociedade, de que paternidade e maternidade, também é um vínculo muito mais social do que biológico, pois "pai e mãe é quem cria". Não basta somente fecundar e conceber uma criança, é necessário cuidar e amar. Portanto se faz necessário analisar a família homoparental, a qual pauta este estudo. Segundo o dicionário informal, o termo homoparental se refere à família na qual o pai ou a mãe se assume homossexual. No entanto, é sabido que há muito tempo a noção de família foi cristalizada segundo a divisão tradicional dos papeis de gênero onde ao homem coube a manutenção da família e à mulher o cuidado da prole. Essa questão nos leva a discutir o problema da identidade de gênero e de família.

\section{IDENTIDADE(S) E FAMÍLIA}

$\mathrm{A}(\mathrm{s})$ identidade(s) pode $(\mathrm{m})$ ser entendidas como os meios sócio-culturais pelos quais indivíduos de uma sociedade são representados. Segundo Argüello (2005, p. 31), "a identidade tem a ver com a representação, que deve ser compreendida como um processo cultural em que significados são produzidos". Desse modo, os diversos aspectos sociais e culturais que diferenciam variados grupos de indivíduos podem ser compreendidos como identidade. Ao se falar em identidade de gênero não se deixa de falar sobre o "ser homem" ou "ser mulher", visto que tais concepções parecem estar 'naturalizadas' no inconsciente de quase todas as sociedades. 
De acordo com Argüello (2005) ao citar Tomaz Tadeu da Silva:

Primeiramente, a identidade não é uma essência, não é um dado ou um fato seja da natureza, seja da cultura. A identidade não é fixa, estável, coerente, unificada, permanente. A identidade tampouco é homogênea, definitiva, acabada, idêntica, transcendental. Por outro lado, podemos dizer que a identidade é uma construção, um efeito, um processo de produção, uma relação, um ato performativo. A identidade é instável, contraditória, fragmentada, inconsciente, inacabada. A identidade está ligada a sistemas de representação. A identidade tem estreitas conexões com relações de poder. (ARGÜELLO, 2005, p. 31 apud SILVA, 2000a, p. 96).

Sabe-se que o conceito de identidade(s) está estreitamente relacionado à sexualidade, outro conceito segundo a qual, Focault (1988) afirma tratar-se de uma relação do "regime de poder - saber - prazer" (p.16). Dessa maneira, o "ser homem" ou "ser mulher" não é nada menos que uma representação cultural criada pela sociedade de acordo com seus interesses particulares e as relações de poder estabelecidas entre os indivíduos. Argüello (2005, p. 75) diz que

[...] todos aqueles comportamentos, representações que se tenham sobre gênero são sempre invenções sociais de um tempo e uma cultura dada; entretanto, as ideias sobre como devem ser produzidas e conduzidas as identidades de homens e mulheres de uma sociedade em particular, passam a ser tão disseminadas num senso comum. A sociedade se esquece que inventou tais identidades e passa a assumi-las como naturais. [grifos da autora].

A representação do modelo convencional de família vem sendo por muito tempo estabelecido como a 'norma' nos paradigmas heteronormativos. Aqui entendemos por heteronormatividade o conjunto de discursos sócio-culturais que excluem qualquer outra forma de representação de identidade diferente da identidade heterossexual. Assim, os elementos constitutivos da identidade da convencionada família "normal" seria a existência de uma figura paterna e uma materna, representadas por indivíduos que se identificam, respectivamente, como 'homem' e 'mulher'. A existência de outros modelos familiares como o homoparental, então é vista como "anormal", "anti-natural”.

\section{FAMÍLIA HOMOPARENTAL NOS PARADIDÁTICOS DE LITERATURA}

Utilizar livros paradidáticos na educação infantil é uma prática constante na maioria das escolas, pois é útil como método de ação educativa.Segundo Costa et Santos (2016) nos livros há um lugar mágico que forma, informa, e "imprime estetizações e modalidades comportamentais" que refletem nos padrões de ser, estar e se comportar. Como lugar de imaginação, os livros configuram parte do mundo da criança onde a fantasia e as diferentes emoções se entrelaçam possibilitando o desenvolvimento cognitivo e afetivo. Para Meireles (1984, p. 128)

A natureza e intensidade dessas emoções podem repercutir na vida do pequeno leitor de maneira definitiva. Não apenas ele se lembrará, até a morte, desse primeiro encantamento, [...]; muitas vezes, a repercussão tem resultados práticos: vocações que surgem, rumos de vida, determinações futuras.

Ao lê-los, as crianças despertam o imaginário e capacitam o afloramento de uma visão de mundo inédita, através do imaginário pretendido nos livros elas passam a adotá-lo como lugar de prazer, onde podem encontrar o mundo perfeito, bastando para isso, explorá-lo.

O livro Nicolás tiene dos papás, é um conto infantil chileno de três mil exemplares, que aborda a história de uma família homoparental, na qual, a criança vive com seus pais Pablo e Sebastián, ao mesmo tempo, relata a relação que todos têm com Clara, mãe de Nicolás. "Mi mamá y mis papássonbuenos amigos y nos gusta almorzar a todos juntos [...]" (p.5). No relato do livro percebemos que existe harmonia felicidade e amor entre eles. Desse modo, a estorinha procura representar a inclusão de um modelo de casal diferente, embora a questão da abordagem desse tema no âmbito escolar ainda parece estar muito aquém da realidade e nossa proposta, portanto se atreve apenas a observar o impacto dessas leituras entre os futuros professores como meio de conscientização das mudanças de paradigmas sociais acerca das noções de família e diversidade familiar. O livro Nicolás tiene dos papás, foi escrito especialmente para o público infantil com o objetivo de fazer com que as crianças cresçam sem discriminação, como 
também paradiversas famílias e pessoas com orientações sexuais e identidade de gênero, como o intuito de promover uma discursão acerca do conceito de família e de sua composição.

Em And Tango make sthree, estória do americano Justin Richardson, publicada em 2005, além de tratar do tema de casais do mesmo sexo, o livro aborda o tema da adoção. Vemos um caso família de pingüins composta por um casal homoparental: Roy e Silo que com ajuda do tratador do zoológico em que vivem conseguem adotar um ovo abandonado e cuidar dele até chocá-lo, quando nasce Tango, a primeira filhote de pingüim do zoológico a ter dois pais. Desse modo, parece que a abordagem desse gênero de literatura busca construir uma identidade familiar de milhares de crianças que não conseguem se ver representadas através das histórias presentes em livros de literatura infantil, visto que a representação de família na maioria das vezes é configurada apenas pelos modelos familiares "convencionais" ou, dentro do discurso heteronormativo, famílias "normais" ou "padrão".

\section{METODOLOGIA}

Utilizamos como procedimento metodológico o estudo de caso, pois nosso objetivo se concentra na compreensão de um fenômeno muito complexo de se tratar, além de buscarmos entender as concepções dos indivíduos participantes subjetivamente. Pois nosso intuito foi entender como as ideologias heteronormativas estão presentes nos discursos desses indivíduos em relação à representatividade de famílias compostas por pais do mesmo sexo e como a literatura infantil pode contribuir, de certo modo, para a manutenção ou mudanças desses discursos e, conseguinte inclusão de outros modelos familiares não convencionais. Dessa forma, logo após algumas reflexões sobre aspectos concernentes aos conceitos de família, identidades, e apresentação de informações relevantes sobre os livros infantis dos quais comentamos na sessão anterior, foi pedido que os participantes da pesquisa lessem os contos (ressaltamos que cinco deles realizaram a leitura na sala de forma coletiva com uma versão impressa e outra versão em PDF em um notebook, os outros sete leram a versão em PDF enviada via e-mail e whatsapp). Logo em seguida, foi realizada uma coleta de dados através de um questionário de duas perguntas abertas e três fechadas a um universo de pesquisa composto por 12 indivíduos.

Como instrumento de pesquisa adotamos um questionário que continha perguntas fechadas sobre idade, sexo e escolaridade as quais utilizamos como variáveis que, possivelmente, poderiam contribuir subjetivamente para um melhor entendimento das opiniões dos informantes da pesquisa. Sendo 11 deles professores de línguas estrangeiras em formação e um já formado. Quatro deles se declararam ser do sexo masculino e nove do sexo feminino. Em relação às perguntas abertas foram lançadas as questões: (01) Qual a sua opinião sobre o tema diversidade de identidades e famílias ser trabalhado na escola? (02) Para você, como este tema pode ser trabalhado através da literatura Infantil em Língua Estrangeira?

Em relação à primeira questão procuramos primeiro compreender como os participantes, como pessoa e como futuros professores de LE, viam essa temática e qual seus pontos de vista sobre a relevância dessa questão como problemática que pode ser abordada na escola. As respostas à segunda pergunta dependiam da primeira, visto que de acordo com o posicionamento do informante na questão (1) esta seria dispensável ou não. Ela foi elaborada propositalmente, pois além de nos indicar possibilidades de como trabalhar a questão em sala de aula, nos interessaria saber também se a opinião dos informantes contra o fenômeno da composição familiar homoparental ocasionaria, direta e consequentemente, em sua oposição à abordagem da temática de diversidade familiar na escola ou se, por outro lado, o indivíduo, como futuro professor(a) de línguas estrangeiras poderia estar aberto a pensar a possibilidade de refletir mais sobre a temática e até, talvez tentar buscar meios de trabalhar questões de respeito as diferenças e possíveis representações dessa diversidade na literatura estrangeira.

\subsection{RESULTADOS E DISCUSSÕES}

Nessa pesquisa adotamos o termo 'famílias diversificadas' para se referir aos modelos de estrutura familiar não convencionais aos padrões heteronormativos, no caso específico de nosso estudo, a família homoparental. Resolvemos não aderir o termo 'famílias diferentes' por acreditarmos que tal nomenclatura possui certo teor de exclusão aos indivíduos que são representados por esse modelo familiar. Dessa maneira, também procuramos promover uma maior reflexão sobre a necessidade de se desnaturalizar a noção da chamada 'família normal' como representação do essencialismo identitário heteronormativo. Nessa perspectiva, como elucidamos em nossos objetivos, procuramos representar a identidade de família homoparental através da literatura infantil como modo de inclusão das crianças que vivem nesse tipo de meio familiar. E dessa forma poder fazer com que elas se sintam representadas na sociedade. 
Dois dos participantes concordam em um ponto referente à necessidade de representatividade de 'famílias diversificadas', pois segundo eles é, muitas vezes, associada a concepções excludentes como "desconstrução ou desestruturação da instituição familiar". Nos trechos a seguir vemos como esses participantes se posicionam frente à necessidade de se trabalhar a diversidade familiar na escola:

Informante 1: "torna-se relevante abordar um tema tão corriqueiro e que muitas vezes é deixado de lado por ser uma desconstrução do padrão convencional familiar [...]."O tema [poderia ser] utilizado em uma sequência didática, por exemplo, por ser um tema atual e que gera discussões construtivas, poderia ser aplicado de diferentes formas para diferentes faixas etárias"; Informante 9: "Acredito que ele deve ser trabalhado a fim de evitar a propagação de ideais apontando a diversidade de gênero como uma intenção de desestruturação da Instituição familiar."

Em contraposição a essas concepções, percebeu-se que alguns dos outros informantes adotaram um posicionamento contrário a abordagem de temas sobre diversidade familiar e identidades e o possível uso de livros paradidáticos infantis que abarcassem a temática no âmbito escolar em, em especial àqueles referentes à homoparentalidade. Dois dos indivíduos alegaram que essa temática era inapropriada para se trabalhar com crianças, pois as mesmas não "possuem maturidade suficiente para compreender o tema com clareza" (Informante 5), ou ainda que "crianças não têm consciência de questões como sexualidade"(Informante 6). Um informante afirmou que "Tal assunto deve ser discutido no âmbito familiar, no lar de cada aluno, com seus pais. Gênero e família são coisas muito de cada pessoa, não precisam ser trabalhados em lugares públicos" (Informante 11). No entanto, esse mesmo informante (11), parece adotar também uma postura mais aberta a compreender as diferenças indentitárias e novos modelos de família na sociedade, apesar de, por outro lado não concordar que o tema seja discutido na esfera escolar, pois nos parece que, a seu ver, a divergência de ideologias heteronormativas e as questões concernentes à problemática poderiam causar impactos ás crianças. Em seu relato ele diz: Informante 11: "Acredito que as pessoas podem assumir o gênero que quiserem e têm o direito de formar famílias que fogem do "padrão", mas quando se pensa em trabalhar na escola, há muitos fatores e pessoas envolvidas, assim, sempre vai causar maus efeitos."

Para confirmar nossa proposição de usar a questão (2) Para você, como este tema pode ser trabalhado na prática das aulas de LE? Com o intuito propositalmente adicional de também conferir se algum dos informantes que se manifestassem contra, mesmo assim, poderia pensar em outras formas de trabalhar a inclusão na escola, mesmo que não abarcasse a questão das identidades de gênero ou homoparentalidade, o informante 11 manifestou uma resposta a segunda questão da seguinte maneira: "Na minha opinião, como já citei na primeira resposta, não acho que tal tema seja apropriado para ser trabalhado na escola, porém, acho bom que se trabalhe através de textos, vídeos e discussões sobre o respeito e o amor fraterno a todas as pessoas, mesmo que sejam diferentes das outras."

De acordo com Focault (1988) mudanças profundas sobre a sexualidade foram difundidas no pensamento ocidental a partir do século XIX. $\mathrm{O}$ autor de História da Sexualidade: A Vontade de saber afirma que"um rápido crepúsculo se teria seguido à luz meridiana, até as noites monótonas da burguesia vitoriana. A sexualidade é, então, cuidadosamente encerrada. Muda-se para dentro de casa. A família conjugal a confisca." (FOCAULT, 1988, p. 9)

Obviamente criticando a postura puritana do comportamento social acerca do tratamento dado à sexualidade e, usando tom irônico a respeito de como o discurso conservador da sociedade passa a ver a criança frente a sexualidade humana Focault (1988, p. 10) diz que "as crianças, por exemplo, sabe-se muito bem que não têm sexo: boa razão para interditá-lo, razão para proibi-las de falarem dele, razão para fechar os olhos e tapar os ouvidos onde quer que venham a manifestá-lo, razão para impor silêncio geral e aplicado".

Fazendo uso do discurso religioso a respeito da questão da opção sexual de indivíduos que não se representam com a identidade heterossexual padrão um dos informantes opina "Para mim Deus criou o homem e a mulher e ambos um para o outro, e não mulher com mulher e homem com homem."(Informante 7). Três dos informantes ressaltaram a importância da abordagem da diversidade familiar na escola através do ensino de literatura como instrumento de inclusão de diferentes formas de famílias e além de ser uma ferramenta eficaz na luta contra os preconceitos, e desse modo, reforçar sentimentos de respeito, solidariedade e companheirismo. Informante 3: "Eu acho correto o ensino do respeito às diversidades para as crianças, a respeitar as novas formas de construir uma família para quando as crianças chegarem na vida real saberem ver que o amor que une elas é a única coisa que importa e que vale a pena respeitar."

Como sugestão de prática pedagógica com o tema o mesmo informante sugere "que seria possível trabalhar esse tipo de literatura através de relatos ou histórias desenhadas com esse tema, mostrando os diversos tipos 
de famílias que existem hoje em dia, assim as crianças vão aprender de uma forma lúdica a respeitar o próximo e a diferença." Assim como nas estorinhas And Tango makes three e Nicolás tiene dos papás apresentadas aos mesmos.

Ainda em relação ao uso da literatura como ferramenta de desconstrução de preconceitos e exclusões sociais mais dois informantes expressão sua opinião sobre como esse instrumento - a literatura infantil poderia ser eficaz na formação de uma consciência aberta à diferença e inclusão de diferentes realidades familiares entre as crianças:

Informante 8: "Os estudos e discussões de gênero em sala é válido para evitar e prevenir possíveis preconceitos ou Pré-julgamentos. Em aulas de língua estrangeira assim como todas as disciplinas são relevantes para a discussão. A literatura (nesse caso em questão) é um recurso para o ensino à reflexão sobre esse assunto, cabendo a escola realizar estes estudos." Informante 10: "A escola é uma fonte incomparável no ensino, local este que pode ensinar as crianças bons exemplos, bem como ensinar a respeitar o outro abordando o assunto (diversidade de gênero) em sala de aula."

Mais uma vez percebemos um ponto de vista convergente sobre a relevância da abordagem de temas sobre a inclusão de 'famílias diversificadas' no âmbito escolar e nas aulas de língua estrangeira compartilhado por três dos informantes. Eles sugerem que é bastante relevante tratar de assuntos ligados a inclusão às diferenças identitárias e diversidade familiar por se tratar de tópicos atuais e que contribuem para a construção do pensamento crítico do aluno, ajudando-o a compreender melhor o mundo em que vivem:

Informante 1: "Acredito ser relevante por possuir um caráter construtivo na aprendizagem, é atual, ou seja, está cada vez mais presente, é necessário a inserção do tema em sala, é algo que precisa ser mais discutido, ou seja torna-se funcional dentro de sala e fora também já que apresenta um teor social, servindo também para a construção do indivíduo." Informante 2: "Assim como outros acontecimentos e mudanças na sociedade são faladas nas escolas esse também deve ser trabalhado." Informante 4: "É uma forma de ver e aprender com o mundo do jeito que ele se encontra nos tempos de hoje, pois as famílias de hoje não seguem aquele exemplo "padrão" que era imposto até meados do século 18."

Para balancear esses posicionamentos a favor ou contra a abordagem da temática 'diversidade de identidades de gênero e de família' apenas um dos informantes parece adotar uma postura mais "neutra" em relação à possibilidade de se trabalhar a questão em sala através da literatura infantil. A informante 12 diz que "O tema não deveria ser obrigatório (assim como qualquer outro) em nenhuma escola. Os pais junto com a coordenação deveriam escolher sobre se determinado tema deveria ou não ser abordado em sala de aula." A nosso ver seu posicionamento mostra-se indiferente, e não parece nem totalmente contra nem a favor, no entanto, parece ser revelar uma postura de ensino menos conservadora ao que se refere a não adotar "conteúdos obrigatórios". A respeito de seu comentário sobre a questão da escolha dos conteúdos dos pais junto à escola isso dependerá muito do contexto escolar para que seja possível ou não a adoção de conteúdos de literatura infantil que trabalhem a respeito do problema. Sendo assim, dentre os indivíduos que participaram dessa pesquisa, sete se manifestaram a favor de trabalhar o tema explicitado em sala de aula através do uso de literatura infantil, sendo 3 deles do sexo masculino e 4 do sexo feminino. Dos que se manifestaram contra contabilizaram 4, dentre os quais 3 do sexo feminino e 1 do sexo masculino. Apenas 1 dos informantes pareceu adotar uma postura mais neutra em relação a abordagem do tema em sala de aula.

\subsection{CONSIDERAÇÕES FINAIS}

Finalizar essa discussão parece ser um desafio ainda maior que iniciá-la, pois discutir literatura já é algo complexo, pois envolve atenção a minúcias que muitas vezes passam despercebidas. Esse desafio torna-se ainda maior quando falamos em uma literatura para crianças que trata de temas tão polemizados e, historicamente tratados como tabus enraizados profundamente no inconsciente social através de discursos heteronormativos.

Nessa pesquisa foram ressaltados os objetivos de se discutir e buscar refletir mais sobre a possibilidade de incluir no âmbito escolar por meio da literatura - nesse trabalho especificamente a literatura estrangeira (mas, obviamente não deixando de considerar as produções sobre essa temática em língua materna) - a abordagem do tema de diversidade de identidades de gêneros e de famílias, especialmente o de famílias homoparentais e a tentativa de construção de uma representação da família homoparental como 'normal', incluindo-a também no imaginário das crianças. Viu-se que a noção de família na atualidade não mais se conforma com os paradigmas convencionados há séculos atrás e hoje estruturas familiares compostas por 
pais do mesmo sexo já é juridicamente legalizada. Foi ressaltado que a noção de família baseada na tradicional composição de um casal de sexo biológico distintos já parece ser uma visão obsoleta, tendo em vista a complexidade de identidades sexuais na atualidade.

Por entender que a abordagem da temática da homoparentalidade na literatura infantil, embora extensa produção de livros infantis nesse campo venha sendo produzida, ainda é um desafio muito grande na realidade das escolas esse trabalho buscou explorar essa temática tão excluída através da percepção dos professores em formação sobre a possibilidade de refletir sobre essa questão e meios de como conseguir levá-las a realidade escolar como ferramenta de inclusão de novos modelos familiares que muitas vezes representam parcelas consideráveis de crianças que não conseguem ver sua família representada na literatura infantil tradicional.

Percebemos que as opiniões dos informantes da pesquisa variaram bastante, fato que demonstra uma mudança positiva em relação às concepções favoráveis a inclusão de literatura infantil representativas de famílias homoparentais, no entanto também observamos que discursos de ideologias heteronormativas ainda exercem uma posição hegemônica mesmo entre indivíduos que declaram não ter preconceito a respeito da diversidade de identidades de gênero. Assim concluímos que a abordagem da temática da família homoparental representada na literatura infantil ainda é um grande desafio que precisa amadurecer e, muito provavelmente renderá muitas pesquisas e muitas dificuldades a percorrer para se tornar uma realidade no meio educacional.

\section{REFERÊNCIAS}

[1] Albuquerque, Cecília; Silomar, Tiago. A família homoparental. O STF proporcionando o sonho da adoção. Jus.com.br / Jus Navigandi - Tudo de Direito e Justiça. Disponível em: https://jus.com.br/artigos/51020/a-familiahomoparental. Acesso em: 26 jun. 2018.

[2] Alves, Isabella Nara Costaet alia.A inclusão do modelo de família homoafetivo nos livrosdidáticos - II CINTEDI - II Congresso Internacional de Educação Inclusiva e II Jornada Chilena Brasileira de Educação Inclusiva, 2016.

[3] Argüello, Zandra Eliza Argüello. Dialogando com crianças sobre gênero através da literatura infantil. Porto Alegre, 2005.

[4] Bittar, Carlos Alberto. Direito de Família. 2. ed. Rio de Janeiro: Forense Universitária, 1993.

[5] Costa, Fábio Soares da; Santos, Andreia Mendes dos. Representação de gênero e literatura infantil: paradidáticos em análise.Educação Por Escrito, Porto Alegre, v. 7, n. 2, p. 263-277, jul.-dez. 2016.

[6] Dicionário Informal. Homoparental. Disponível em: https://www.dicionarioinformal.com.br/significado/homoparental/3063/. Acesso em 26 jun. 2018.

[7] Dresch, Márcia.A instituição familiar na legislação brasileira: conceitos e evolução histórica. Jus.com.br / Jus Navigandi - Tudo de Direito e Justiça, 2016. Disponível em: https://jus.com.br/artigos/51795/a-instituicao-familiarna-legislacao-brasileira-conceitos-e-evolucao-historica. Acesso em: 27 jul. 2018.

[8] Focault, Michel. História da sexualidade I: A vontade de saber. Tradução de Maria Thereza da Costa Albuquerque e J. A. Guilhon Albuquerque. Rio de Janeiro, Edições Graal, 1988.

[9] Meireles, Cecília. Problemas da literatura infantil. 3. ed. Rio de Janeiro: Nova Fronteira, 1984.

[10] Nicholls, Leslie; Gómez, Rámon. Nicolás tiene dos papás. Movilh. 1 ed. Santiago, 2014.

[11] Richardson, Justin; Parnell, Peter; Cole Henry. And Tango Makes Three. New York: Simon \& Schuster Books For Young Readers, 2005. Print. 


\section{Capítulo 4}

Diversidades em tela: 0 uso dos recursos audiovisuais como elementos discursivos para superação da desigualdade na escola e do Preconceito de Raça, Gênero e Identidade

Carla Thayse dos Santos alves

Espedito dos Santos Júnior

João Antônio da Silva Fernandes

Maria Eluiza Soares da Silva

Marcos Paulo de Oliveira Sobral

Resumo: O Projeto Diversidades em Tela: o uso dos recursos audiovisuais para combater o preconceito de raça, gênero e identidade, faz uso dos recursos audiovisuais como elementos discursivos para superação da desigualdade na escola e do preconceito de raça, gênero e identidade, tem como objetivo promover ações que favoreçam ao diálogo, reflexão e ação dos sujeitos protagonistas em relação ao preconceito e suas variáveis. Os encontros nas escolas aconteceram quinzenalmente, intercalado por período para o planejamento das atividades que foram aplicadas na semana subsequente. A partir do uso de recursos audiovisuais junto aos alunos nas escolas o projeto teve como resultado a produção de atividades que envolvessem toda a comunidade extensionista (sujeitos das escolas e UFAL) tendo como produto um documentário que revela as percepções sobre o problema social da temática proposta. 


\section{INTRODUÇÃO}

O presente projeto nasceu da urgência em se resgatar a função social da escola pública de Penedo, mobilizando seus atores, contemporizando suas ações e da mesma forma, melhorando a qualidade da educação que a mesma prática. Neste sentido, é consensual que o processo ensino-aprendizagem esteja associado cada vez mais às atitudes dos seus envolvidos. Desse modo, impera-se que as aprendizagens associem-se cada vez mais às ações desses sujeitos a partir da e sobre a realidade.

Por outro lado, a relação Ensino-Pesquisa-Extensão não pode ser vista como atividades com fim em si mesmas, mas articuladas à construção de diálogos, de aprendizados mútuos, ou seja, numa abordagem dialógica onde os atores protagonistas da aprendizagem, construam mutuamente seus saberes, restabeleçam conceitos e produzam leituras da e na realidade em que estão inseridos. A partir desses pressupostos parte-se da compreensão do quanto se torna relevante o estabelecimento de um novo paradigma sobre Educação focada nas diversidades dos estudantes, considerando que a formação cultural de Alagoas, em especial em Penedo, e Igreja Nova foi marcada pela fusão de etnias, culturas, diferentes ocupações geográficas, diversidade de fisionomias e paisagens, além das multiplicidades culturais. Compreendemos que a formação dos estudantes das escolas públicas ainda necessita avançar sobre esses diversos aspectos. Por isso, esta proposta de projeto de extensão se configura como uma ação essencial que visa incentivar a postura de sujeitos críticos capazes de refletir sobre suas identidades e realidades. Diante disso, assumimos como metodologia a pesquisa colaborativa interventiva nas escolas públicas de Penedo e Igreja Nova.

Assim, é objetivo geral refletir as relações que acontecem também fora da instituição escolar, ou seja, se reproduz dentro e fora do espaço escolar práticas de violência física, psicológica e etc...

A discussão em tela buscou tencionar as práticas que catalisam papéis e representações sociais que nos remetem à necessidade de se repensar a partir da escola - espaço privilegiado por ser a instituição social que mais agrega sujeitos com identidades e diferenças culturais, sociais, religiosas, sexuais e uma série de tantas outras dimensões sócio históricas - o debate, reflexão e tomada de novas atitudes perante as situações de opressão antes vivenciadas pelos atores sociais envolvidos.

\section{CARACTERIZAÇÃO DA REGIÃO}

O lócus privilegiado para o desenvolvimento das ações extensionistas do projeto se dá pela perspectiva da inserção da universidade na região do baixo São Francisco, especificamente na cidade alagoana de Penedo e os municípios circunvizinhos de Igreja Nova e Piaçabuçu. Marcadas pelo histórico de poucas oportunidades de acesso ao trabalho que garanta à geração de renda e não diferente disso o acesso a educação básica ou superior. Isso pode ser caracterizado pela forma como estão distribuídos os prédios escolares nos espaços geográficos dessas duas cidades. As cidades citadas, apresentam os seguintes indicadores: Penedo possui uma população estimada em 64.497 pessoas (2017), com a taxa de Escolarização de 6 a 14 anos de 94,6 \% (2010) e um Produto Interno Bruto - PIB - per capita de $\mathrm{R} \$ 11.557,76$ (em 2015).

Já a cidade de Igreja Nova possui uma população estimada de 24.408 pessoas (2018), com taxa de escolarização de 6 a 14 anos de 97,9 \% (2010); PIB per capita (2015) de R \$13.878,15. Já Piaçabuçu possui uma população de 17.805 pessoas (2018) com taxa de escolarização de 6 a 14 anos de 96,8 \% (2010); PIB per capita (2015) de $\mathrm{R} \$ 10.555,59$.

Não diferente das outras cidades nordestinas que compõem a região geográfica brasileira, a cultura do patriarcado, as relações de poder que se constituíram historicamente demarcam cenários de preconceito, machismo, misoginia, e outras formas de opressão, marcadas por situações esparsas, mas que merecem ser combatidas, discutidas e repensadas pela sociedade, em especial pela escola.

A exemplo disso podemos citar as questões relacionadas à violência contra mulher, os problemas relacionados ao abuso sexual de crianças e adolescentes, a falta de oportunidade de jovens da inserção do mercado de trabalho, os problemas relacionados ao trabalho escravo que caracterizam a forma desigual como o acesso à educação e os aparatos culturais foram sendo construídos no Brasil. Assim, justifica-se a relevância do desenvolvimento desse projeto nessas microrregiões, tendo em vista a urgência e a necessidade presente de que nós enquanto universidade, possamos numa perspectiva dialógica junto a comunidade, ouvir, debater, tencionar, refletir e propor encaminhamentos construídos coletivamente para superação dos problemas já citados. 


\section{METODOLOGIA}

Ao optarmos pela investigação qualitativa e adotarmos a abordagem metodológica da pesquisa colaborativa (DESGAGNÉ, 2007; IBIAPINA, 2008), os espaços das escolas loci da investigação tornaram-se lugares praticados (CERTEAU, 2007), por professoras das escolas, professores da universidade e estudantes da escola e da universidade, entre outros sujeitos, que romperam com as suas estabilidades para irem ao encontro de outras possibilidades de se pensar Identidades e preconceitos.

Assim, essa pesquisa deve superar a perspectiva de pesquisas de constatação ao, [...] dar conta não somente da compreensão da realidade macrossocial, mas, sobretudo, em dar poder aos professores para que eles possam compreender, analisar e produzir conhecimentos que mudem essa realidade, desvelando as ideologias existentes nas relações mantidas no contexto escolar (IBIAPINA, 2007, p. 31): A pesquisa aconteceu em 02 (duas) escolas públicas da rede municipal e 2 (duas) da rede estadual situadas em Penedo e Igreja Nova.

0 processo de investigação aconteceu de forma diferente em cada escola, em respeito aos seus acontecimentos cotidianos - reuniões pedagógicas, calendário letivo, festividades da escola, ausências das professoras, paralisações, entre outros, considerando os limites do tempo escolar que é um tempo social e administrativo imposto aos indivíduos, é um tempo forçado" (TARDIF; LESSARD, 2005, p. 76), um tempo, muitas vezes, sem espaço para a reflexão sobre o fazer pedagógico.

Neste percurso de investigação, os estudantes não serão reconhecidos apenas como meros executantes de receitas pedagógicas bem-sucedidas, ao contrário serão estimulados a se reconhecerem como produtores autônomos de suas histórias, compreendendo, portanto, que a pesquisa tem uma intencionalidade emancipatória, ao assumir, também, uma dimensão política na formação dos estudantes. Buscamos superar a concepção de se investigar sobre os estudantes e professores da escola pública passando a investigar com eles. Metodologicamente, as sessões de estudos, enquanto espaço de diálogo teóricoprático, aconteceram a cada quinze dias, em cronograma construído junto com as escolas e assim respeitando as especificidades do calendário escolar das redes de educação de Penedo e Igreja Nova. A esse respeito, Ibiapina (2007, p. 114 - 115) afirma que: [...] quando o pesquisador aproxima suas preocupações das preocupações dos professores [e dos estudantes], compreendendo-as por meio da reflexividade crítica, e proporciona condições para que os professores revejam conceitos e práticas; e de outro lado, contempla o campo da prática, quando o pesquisador solicita a colaboração dos docentes [e dos estudantes] para investigar certo objeto de pesquisa, investigando e fazendo avançar a formação docente, esse é um dos desafios colaborativos, responder às necessidades de docentes e os interesses de produção de conhecimentos.

O projeto foi dividido em dois momentos chaves: o primeiro desenvolvido foi com a realização de encontros semanais para a formação dos oficineiros, que posteriormente aplicaram essas metodologias desenvolvidas na oficina nas escolas, já no segundo momento, os mesmos colocaram em prática as atividades planejadas durante esse processo de formação. Os encontros nas escolas aconteceram quinzenalmente, intercalado pelo mesmo período para o planejamento das atividades que seriam aplicadas na semana subsequente. Para subsidiar novas ações nas escolas campo empírico, foram sistematizadas práticas de avaliação através da escuta atenta dos protagonistas e de suas percepções sobre a realidade vivenciada.

- Primeiro momento

Houveram encontros para a discussão das atividades e temáticas que seriam abordadas com os alunos nas escolas. O planejamento das atividades foi elaborado para uma turma de 5ㅜ ano de uma escola da rede municipal de Penedo - Alagoas. 


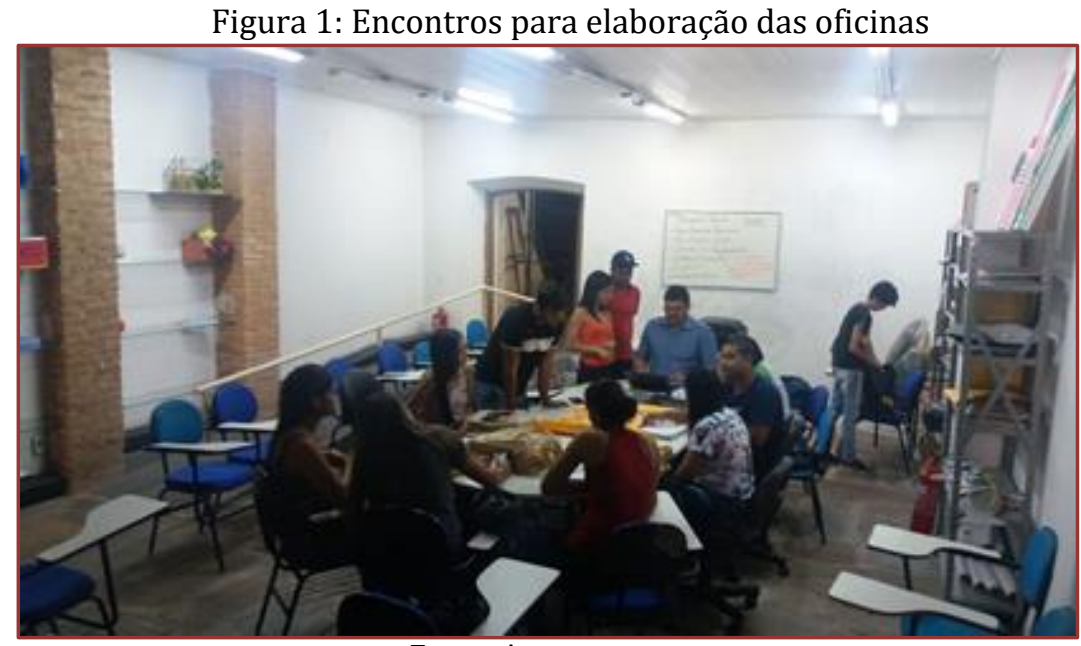

Fonte: Autores

Figura 2: Encontros para elaboração das oficinas

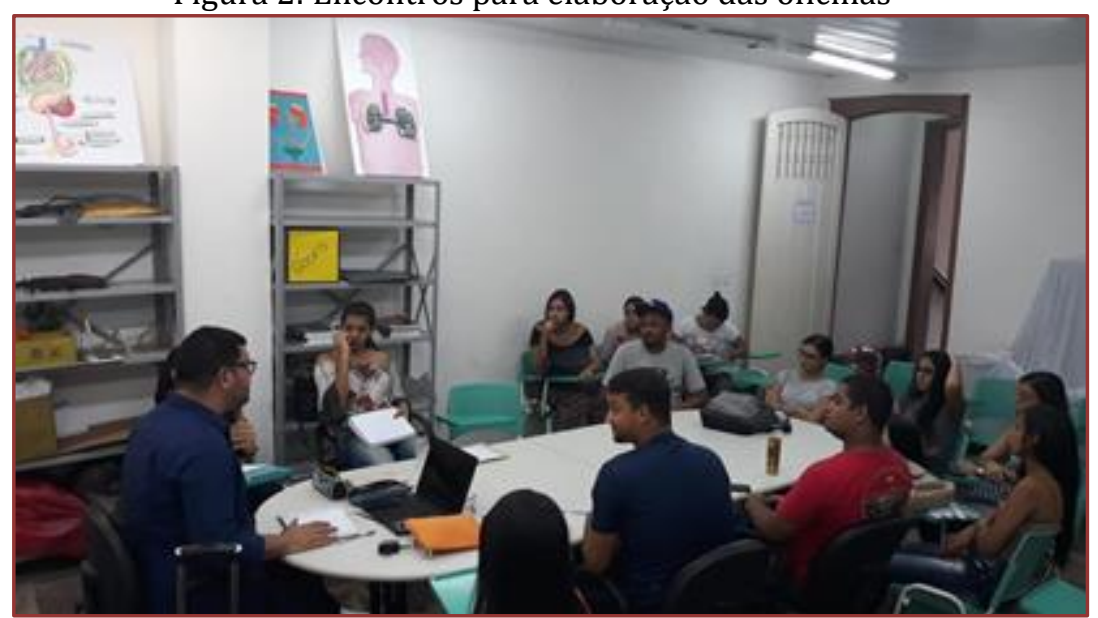

Fonte: Autores

\section{- Segundo momento}

Como dito anteriormente a escola escolhida é da rede municipal de Penedo -Alagoas está localizada em uma comunidade remanescente quilombola (conhecida hoje como "quilombo urbano"). No entanto, cabe destacar que apesar de estar situada em uma região quilombola, a escola atende também a filhos de pais advindos da comunidade cigana, que a pouco mais de dez anos se estabeleceram no bairro.

Hoje, a escola tem como modalidade a Educação infantil (Jardim I e Jardim II) e Ensino Fundamental anos iniciais, com um total de 98 alunos, distribuídos em 4 turmas no matutino e 3 turmas no vespertino, e dispondo dos programas Escola 10 para o $4^{\mathrm{o}}$ ano, programa mais alfabetização e laboratório de aprendizagem para assistência aos alunos.

Ao todo nessa escola aplicamos quatro atividades cada uma delas foram feitas no intervalo de quinze dias com duração de aproximadamente três meses devido ao calendário da escola e disponibilidade das aulas. Abaixo citamos as atividades, temáticas e metodologias utilizadas nas aulas. 


\section{ATIVIDADE 1: IDENTIDADE E GÊNERO}

Objetivo: Trabalhar a percepção da identidade e gênero dos alunos, através de desenhos em bonecos.

Atividade: Começamos a aula questionando os alunos sobre o conhecimento prévio que eles tinham sobre o que viria a ser identidade e gênero, alguns participaram e deram sua opinião à respeito do assunto. Em seguida falamos um pouco sobre o conceito de identidade e entregamos a eles uma folha A4 com a representação de dois bonecos em branco, representando fenótipos de um homem e uma mulher. A atividade consistia no desenho e preenchimento dos bonecos através da representação que os mesmos tinham sobre gênero e identidade. Os alunos desenharam e coloriram de acordo com suas preferências.

Resultados: A realização da atividade foi bastante satisfatória com a participação da maioria, com exceção de uma aluna que relutou em participar da atividade a princípio, mas com a intervenção de um dos oficineiros ela passou a participar mais efetivamente da atividade.

Ao final, foi confeccionado um cartaz onde foram colados os bonecos confeccionados pelos alunos (ver figura 4). Durante toda a atividade foi estimulado à participação de todos, bem como o incentivo à socialização dos mesmos durante a realização da atividade. Cabe destacar que toda a atividade foi realizada na presença da professora responsável por ministrar as aulas na sala, onde em alguns momentos também se fez colaborativa para o desenvolvimento das atividades.

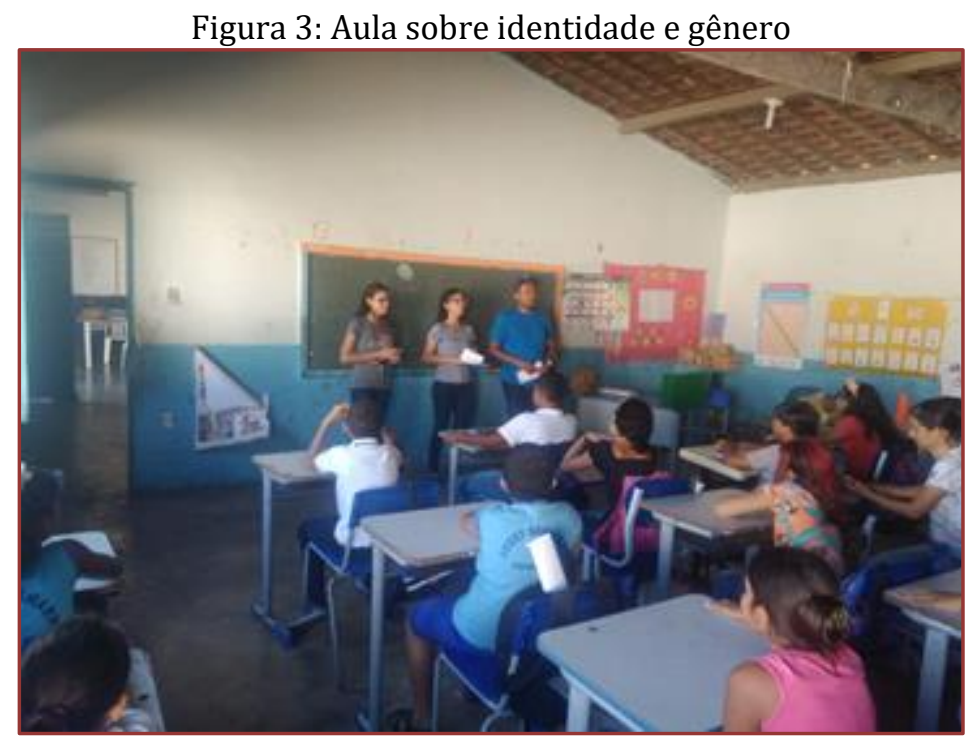

Fonte: Autores

Figura 4: Alunos colando os desenhos no cartaz

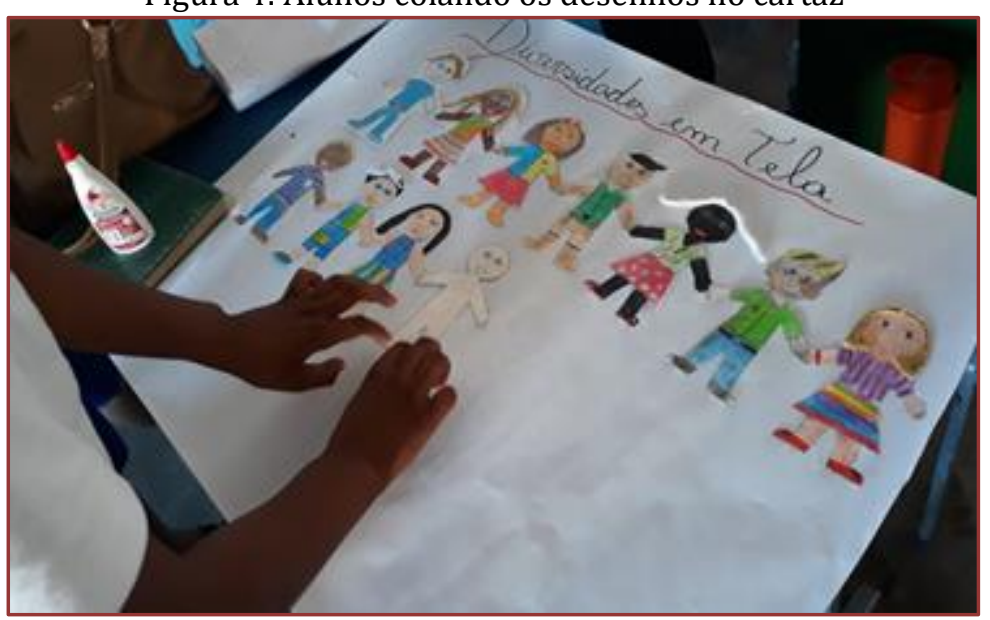

Fonte: Autores 


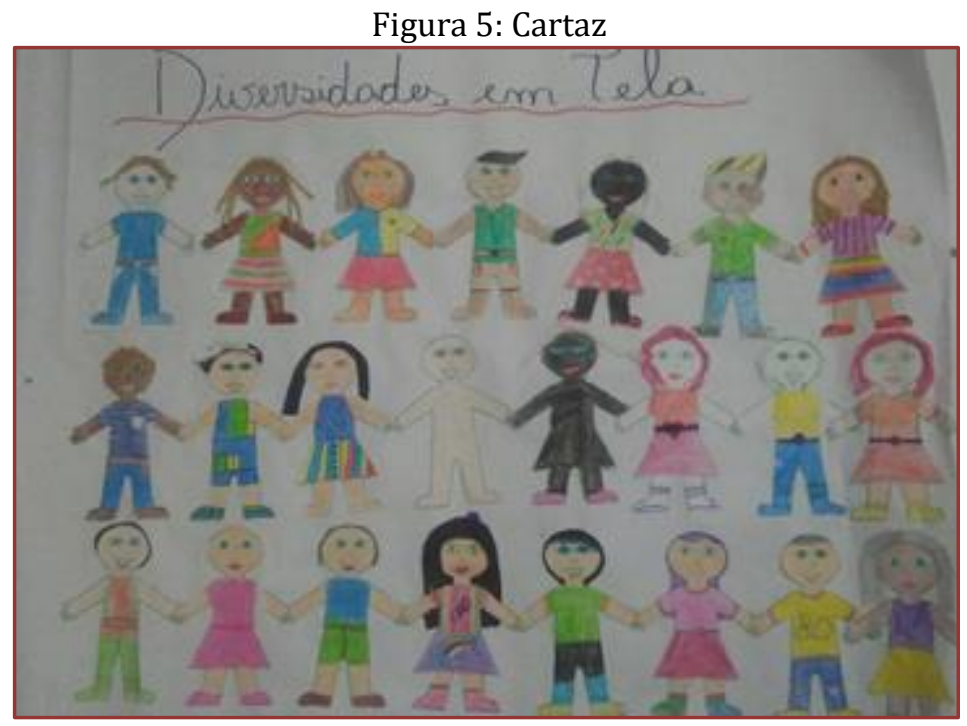

Fonte: Autores

\subsection{ATIVIDADE 2: CONSCIÊNCIA NEGRA}

Objetivo: Reflexão sobre o "Dia da Consciência Negra" através de (re)conhecer o papel de negros e negras que marcaram a história ao longo dos anos, apresentando um curta metragem abordando o tema sobre a menina bonita do laço de fita.

Atividade: A aula iniciou com uma exposição sobre o dia da Consciência Negra comemorado naquela semana, em virtude de alguns problemas não foi possível à utilização de data show como recurso áudio visual, em vez disso com auxílio de notebook, foi apresentando slides com imagens dos negros e negras que marcaram a história como: Zumbi dos Palmares, Martin Luther king, Nelson Mandela, Machado de Assis, Dandara dos Palmares e Tereza de Benguela. Imagens essas reforçadas por falas dos oficineiros que contaram um pouca da história de cada um e sua contribuição para a luta e conquista pela liberdade dos negros daquela época, mesmo que ainda crescente, dos negros na sociedade pós-escravatura.

Em seguida apresentamos curta metragem recomendado pelo Ministério da Cultura, com o título: A Menina Bonita do Laço de Fita (2013). O curta apresenta questões reflexivas sobre étnico raciais direcionadas a crianças em desenvolvimento. Após apresentação expositiva e da curta metragem foi realizada uma dinâmica chamada "jogo de cartas", jogo este que consistia na retirada de uma carta que lhes dava direito de responder uma pergunta relacionada ao curta, ou a correlacionar uma pequena descrição bibliografia a figura que contendo a foto da figura e questão.

Resultados: Por se tratar do nosso segundo contato, os alunos se mostraram ansiosos para saberem qual atividade seria trabalhada no encontro. Durante a apresentação dos slides eles se mostraram bastante interessados no que estava sendo dito, sobretudo nos assuntos tocantes a identidade, raça e cor.

Nesse momento os oficineiros fizeram questão de reforçar os valores de identidade e reconhecimento de sua cor através da auto declaração. Foi também lhes repassado um pouco da historiografia do papel do negro na sociedade brasileira e mundial. Já no segundo momento, a realização do jogo de cartas, houve a participação de todos que se dividiram em equipes para a realização da atividade proposta.

A atividade mostrou uma reflexão dos saberes trazidos pelos oficineiros sobre a temática da consciência negra, como também o despertar da curiosidade dos mesmos durante a realização da brincadeira. 


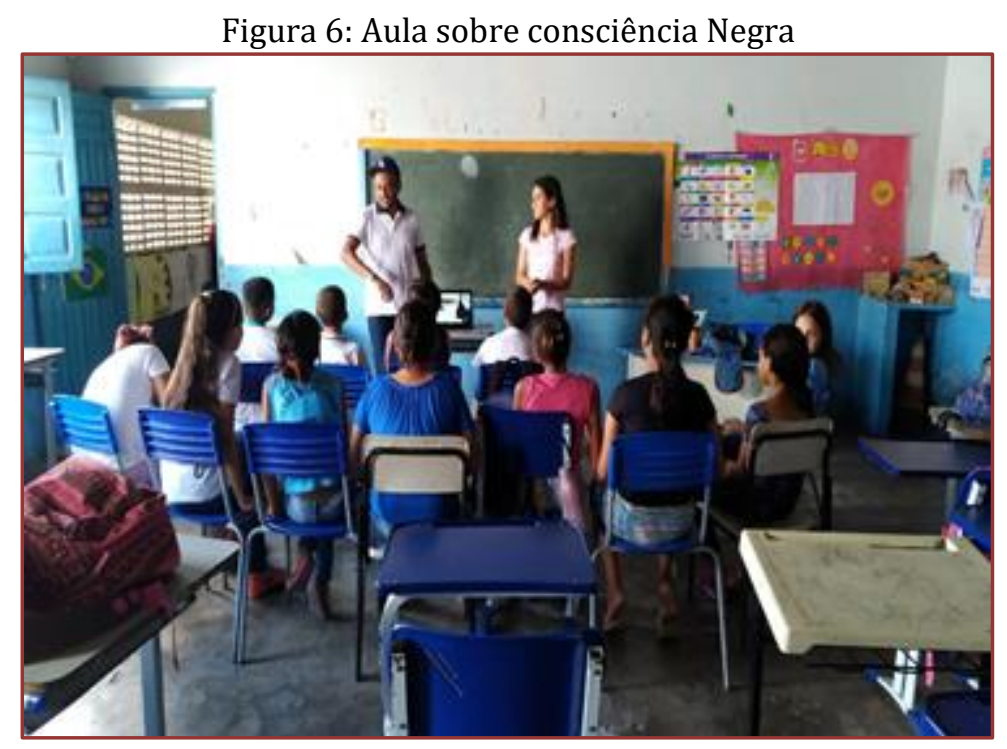

Fonte: Autores

Figura 7: Alunos participando do jogo de cartas

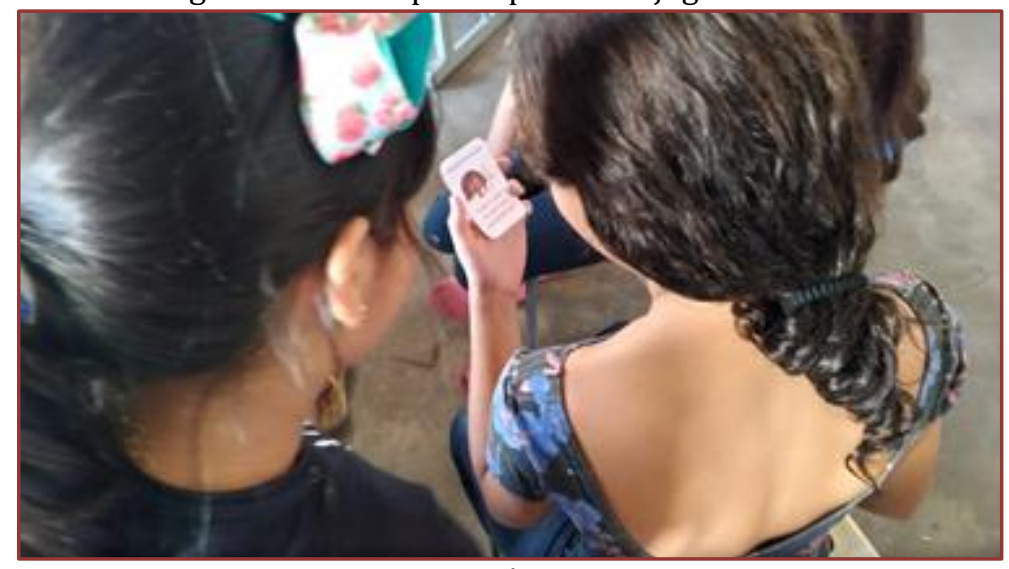

Fonte: Autores

\subsection{ATIVIDADE 3: BULLYING NA ESCOLA E PRECONCEITO}

Objetivo: Fazer uma reflexão à respeito das consequências do preconceito e bullying na escola, através de curtas metragem.

Atividade: Os oficineiros fizeram uma pequena fala sobre bullying e suas consequências no ambiente escolar, após o encerramento das falas, com auxílio de projetor e notebook, passaram duas curtas que abordam o tema em questão: Bullying não! Ser diferente é legal - Canal da Charlotte (2018); e Imagine uma Menina com Cabelos de Brasil (2010).

Logo após a passagem dos curtos foi feita uma pequena discussão sobre a implicação do bullying, promovendo assim a reflexão dos alunos. Por fim foi disponibilizado um questionário contendo perguntas relacionadas a traços corporais e como se auto identificavam com esses, questões ligadas a gostos subjetivos como comida favorita e idealização de sonho e, por fim a representação de como se viam através da produção de um desenho.

Resultados: No decorrer da atividade denominada "minha identidade", os alunos a princípio se mostraram ter dificuldades em responder ao questionário onde contia questões de como eles se identificavam, assim, questionaram a professora sobre as questões de traços corporais e idealização de sonho. Diante disto os oficineiros sugeriram que os alunos se esforçassem para realizarem a atividade de acordo com os saberes e que lhe foram repassados sobre tal temática, com toda dificuldade os alunos conseguiram realizar os questionários sozinhos e, desenharem uma auto representação de como se veem diante da sociedade. 
A atividade foi de grande valia, pois podemos observar diferentes realidades como vista nas fotos anexadas abaixo. Nela podemos ver a representatividade que os alunos têm de se. Com o encerramento da atividade os oficineiros propuseram que os alunos desenvolvessem atividade com auxílio da professora responsável pela sala, tal atividade consistia na produção de uma poesia que abordasse temas relacionados aos trazidos na oficina. Para a realização os alunos dividiram-se em duplas e, alguns escolheram por trabalhar individualmente. Ficou acordado que a apresentação dos trabalhos seria no próximo encontro junto com a confraternização de encerramento dos trabalhos na escola.

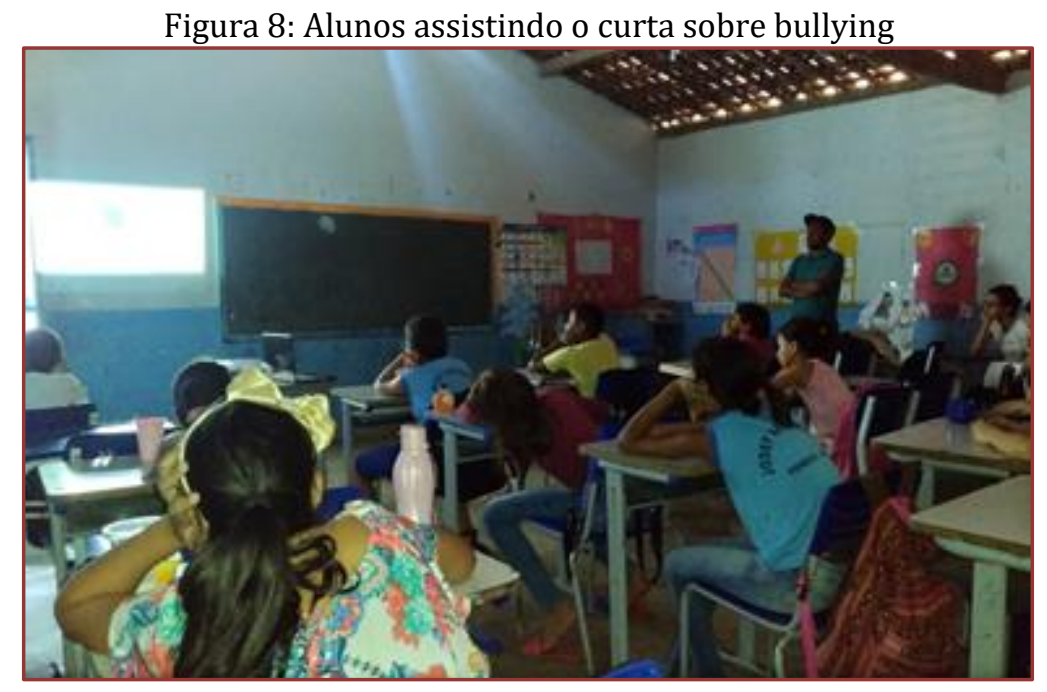

Fonte: Autores

Figura 9: Atividade sobre minha identidade

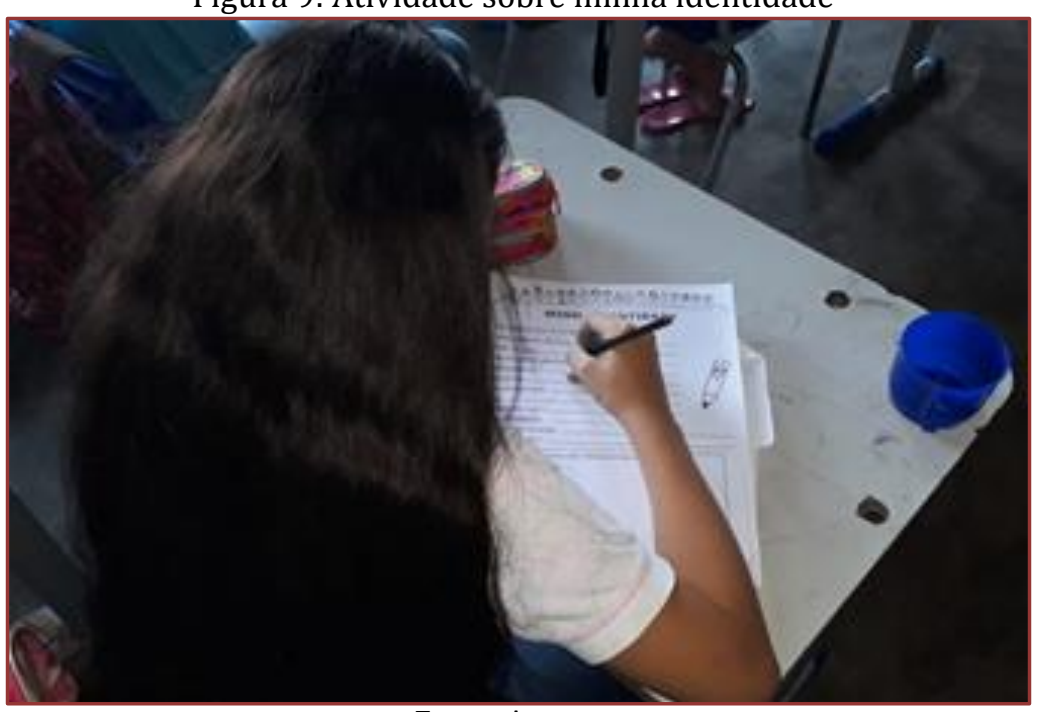

Fonte: Autores

\subsection{ATIVIDADE 4 - CONFRATERNIZAÇÃO E DINÂMICA DA BOLA}

Objetivo: Promover a socialização e revisar os conteúdos trabalhados nas atividades anteriores.

Atividade: Mais uma vez os oficineiros fizeram uma pequena introdução dos temas abordados até então, sempre pedindo a intervenção dos alunos sobre dúvidas e questionamentos. Como relatado anteriormente foi proposta atividade extraclasse para os alunos, a confecção da poesia. Finalizando as falas dos oficineiros, os alunos deram início a apresentação dos poemas produzidos por estes, tanto em dupla quando individualmente. Logo após foi formado um semicírculo pelos alunos para uma melhor fluidez no 
desenvolvimento da atividade, que se daria através da aplicação de Jogo temático com perguntas relacionadas aos temas de diversidade, identidade, cor, raça, bullying e socialização entre os discentes.

O jogo consistia em passar uma bola enquanto é ouvida uma música, ao parar da mesma o aluno que ficou com a bola ia em direção ao centro onde se encontrava um oficineiro e lhes foi dada o direito de estourar uma bola onde dentro contia a pergunta ou ação para que o discente executasse.

Resultados: A apresentação dos poemas foi um momento de extrema realização, pois podemos ver o esforço dos alunos para sua produção, bem como a síntese dos conteúdos sendo trabalhados transversalmente a outras formas de linguagem. Os alunos se mostraram bastante participativos para a apresentação de seus poemas tanto em duplas quanto individualmente .Para a realização da segunda atividade foi desenvolvido um jogo englobando os temas trabalhados ao longo do projeto na escola, onde houve a participação de todos presentes, onde foi possível ver a mudança de percepção dos mesmos sobre os temas trabalhados.

Por fim, foi realizada uma confraternização entre os oficineiros e os discentes encerrando assim os trabalhos com a turma, que a partir do próximo semestre deixará a escola partindo para realização de sua jornada.

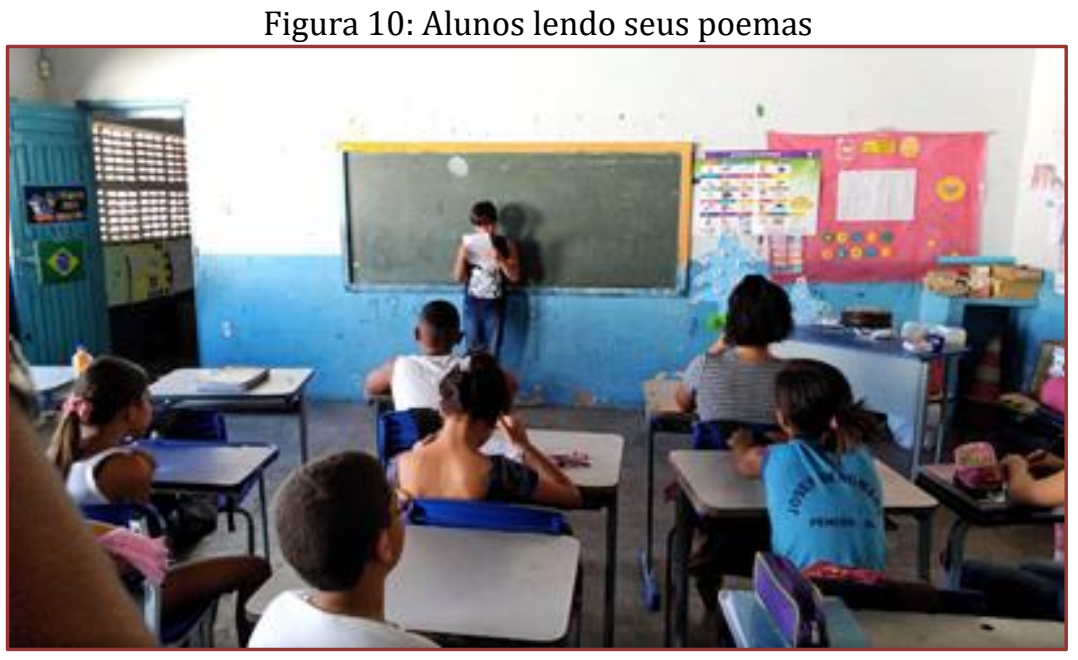

Fonte: Autores

Figura 11: Dinâmica com a bola

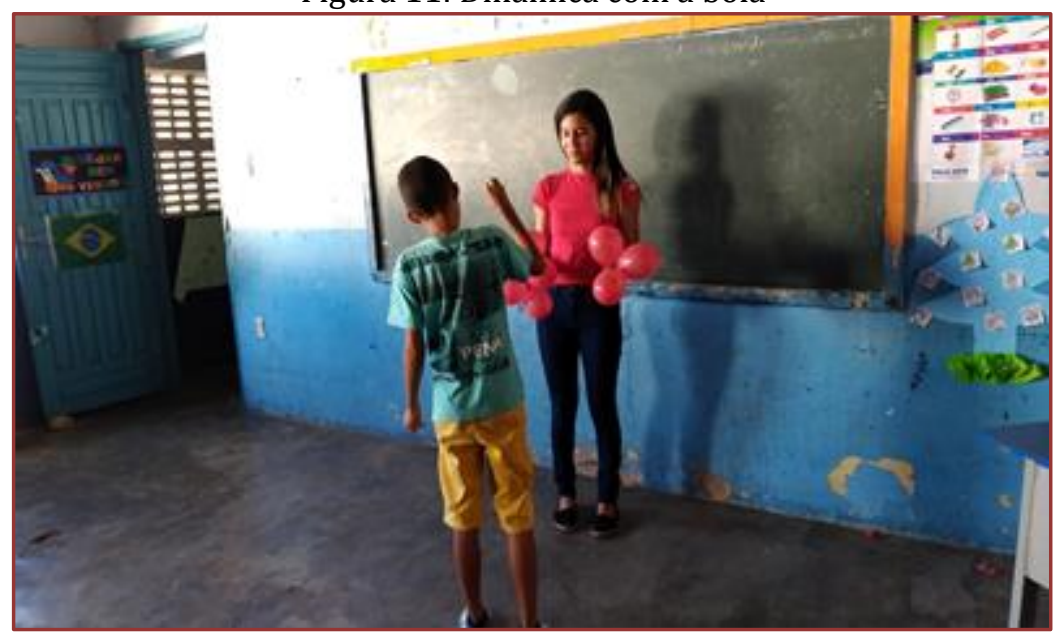

Fonte: Autores 


\subsection{RESULTADOS E DISCUSSÕES}

Estamos inseridos num cenário de bruscas e intensas mudanças e a inserção dos meios digitais provoca alteridades muito rápidas, redimensionando as práticas sociais, a maneira de pensar, de perceber, de sentir e, consequentemente, também a produção de sentidos e significados das relações interpessoais.

Foi a partir do contato inicial com as escolas da rede municipal de Penedo/AL e Igreja Nova/AL, ambas localizadas na região do baixo São Francisco, que identificamos a possibilidade de explorar a utilização dos recursos audiovisuais na construção de um diálogo aberto e franco com a juventude no sentido de estabelecermos uma escuta atenta sobre as representações sociais dos sujeitos acerca da diversidade, do multiculturalismo e da desigualdade e do preconceito seja ele de qual vertente.

Não obstante a esse cenário, a escola vem sendo chamada a assumir seu protagonismo e promover a discussão, reflexão e tomada de novas atitudes perante o desenho social que temos hoje em construção. Para tanto, estão surgindo muitas ferramentas que auxiliam no processo de ensino aprendizagem. Uma dessas ferramentas é o uso de recursos audiovisuais em sala de aula, unindo-se às práticas de aula sociodialógicas ao uso de textos, imagens e vídeos relacionados ao tema abordado.

É com base nesses aspectos que o projeto busca fomentar o uso do recurso do audiovisual como um elemento discursivo junto aos alunos nas escolas, abordando o tema preconceito (raça, gênero e identidade) e a desigualdade na escola. É importante ressaltar que o propósito será estabelecer uma relação com o público alvo deixando aberto para opiniões e discussões acerca da temática abordada considerando a diversidade de cada um. 0 resultado esperado será a produção de atividades que envolva toda a comunidade extensionista (sujeitos das escolas e UFAL) tendo como produto um documentário que revele as percepções sobre o problema social da temática proposta.

\section{CONCLUSÃO}

A guisa de conclusão, como nosso projeto de extensão se encontra em desenvolvimento, ainda não possuímos resultados efetivos das ações, mas ressaltamos que a temática em tela é de suma importância para a promoção de novas estéticas relacionais sejam na escola, na família, no trabalho, ou seja, em todas as agremiações sociais das quais nós sujeitos de relações sociais, fazemos parte.

Tendo em vista as contribuições teóricas que a discussão sobre a diversidade tem produzido em relação às transformações nas concepções de identidade, cultura, relações sociais e sendo a escola uma das instituições sociais que mais lida com as alteridades e estando no seio da nossa sociedade, cabendo a esta, ser protagonista das discussões sobre as questões relacionadas à desigualdade e ao preconceito. Que façamos a nossa parte, por uma educação e uma sociedade que está por vir!

\section{REFERÊNCIAS}

[1] Canal da Charlotte. os Óculos Mágicos de Charlotte - Episódio 2. Direção geral: Filipe Fratino. 2018. ( 3:50min). Disponível em: https://www.youtube.com/watch?v=0i3K9KDt_FY . Acesso em: 02 de dez. de 2019.

[2] Certeau, M. A invenção do cotidiano 2: morar, cozinhar. Petrópolis: Vozes, 2007.

[3] Desgagné, S. O conceito de pesquisa colaborativa: a ideia de uma aproximação entre pesquisadores universitários e professores práticos. Revista Educação em Questão. Natal, v. 29, n. 15, p. 7-35, maio-ago. 2007.

[4] IBGE - Instituto Brasileiro de Geografia e Estatística, 2010 - Disponível em:<https://cidades.ibge.gov.br/brasil/al/igreja-nova/panorama> Acesso em 02 de set de 2018.

[5] IBGE - Instituto Brasileiro de Geografia e Estatística, 2010 - Disponível em:< https://cidades.ibge.gov.br/brasil/al/penedo/panorama> Acesso em 02 de set de 2018.

[6] IBGE - Instituto Brasileiro de Geografia e Estatística, 2010 - Disponível em:< https://cidades.ibge.gov.br/brasil/al/piacabucu/panorama> Acesso em 06 de set de 2018.

[7] Ibiapiana, I. M. L de M. (Org.). Formação de professores: texto \& contexto. Belo Horizonte; Autêntica, 2007.

[8] Ibiapina, I. M. Pesquisa Colaborativa: investigação, formação e produção de conhecimentos. Brasília: Líber Livro Editora, 2008.

[9] Imagine Uma Menina Com Cabelos de Brasil. Diretor: Alexandre Bersot. 2010. (10min). Disponível em: https://www.youtube.com/watch?v=ySx58N50REg\&t=272s . Acesso em: 02 de dez. de 2019.

[10] Menina Bonita do Laço de Fita. Direção: Diego Lopes e Claudio Bitencourt. Produção: Oger Sepol Produções. 2013. (7 min). Disponível: https://www.youtube.com/watch?v=UhR8SXhQv6s. Acesso em: 19 de nov. de 2019.

[11] Tardif, M; Lessard, Claude. O trabalho docente: elementos para uma teoria da docência como profissão de interações humanas. Petrópolis: Vozes, 2005. 


\title{
Capítulo 5
}

De quem se fala e para quem se fala? O ensino de Geografia e a diversidade Étnico-Racial

\author{
Andrêssa Glaucyara Silva Ramos \\ Maria Dayanny Goncalves \\ Gabriela Cavalcanti Lucena \\ Maria Gracielle Vieira Pedroza \\ Aparecida Carneiro Pires
}

Resumo: No contexto escolar, há uma grande diversidade cultural e racial que nem sempre são contempladas. Considerar tais especificidades torna-se essencial para que se entenda a afirmação e reprodução de uma cultura hegemônica, a qual perpetua-se também através do currículo e dos livros didáticos. Compreendendo a escola como um ambiente de encontro de diferentes culturas, o trabalho aborda discussões do currículo como uma construção social, caracterizando-se como "arma" ideológica, que contribui para a supremacia de uma cultura dominante sobre as outras e, posteriormente, problematiza acerca da discussão da temática étnico-racial no ensino de Geografia, a partir do livro didático e da Lei no $10.639 / 03$. Diante disso, são apresentadas reflexões acerca da Lei $\mathrm{n}^{\circ} \mathrm{0}$ 10.639/03, que estabelece a obrigatoriedade do ensino de História e Cultura Afro-Brasileira em todo o currículo escolar, na qual trataremos especificamente do ensino de Geografia para o Ensino Fundamental I. Neste sentido, temos como objetivo refletir como ensino e o livro didático podem contribuir para a perpetuação de práticas de exclusão e reforçar a supremacia de uma cultura dominante, desconsiderando a diversidade racial e cultural existente na sociedade e no próprio contexto escolar. Para tanto, a metodologia de estudo utilizada foi a pesquisa bibliográfica, por tratar de materiais já publicados sobre a temática, a fim de fundamentar tais discussões. Mediante o exposto, identificamos que o currículo não é neutro, havendo interesse de determinadas classes, que perpetuam-se através deste e, consequentemente, influenciam diretamente no ensino.

Palavras-chave: Educação, currículo, Geografia, diversidade, Lei no 10.639/03.

*Artigo apresentado e publicado nos Anais do III Congresso Internacional de Educação Inclusiva - III CINTEDI, V. 1, 2018, ISSN 2359-2915. 


\section{INTRODUÇÃO}

O presente artigo objetiva refletir como o ensino e o livro didático podem contribuir para a perpetuação de práticas de exclusão e reforçar a supremacia de uma cultura dominante, desconsiderando a diversidade racial e cultural existente na sociedade e no próprio contexto escolar.

0 trabalho foi elaborado mediante as problemáticas de exclusão e desvalorização dos sujeitos afrodescendentes no contexto escolar que, para Gonçalves (1997, p. 28, apud Cavalleiro, 2003, p. 32), “[...] exclui dos currículos escolares a história de luta dos negros na sociedade brasileira e 'impõe às crianças negras um ideal de ego branco'", havendo então um currículo reprodutor de uma cultura dominante e nãorepresentativo das diferentes culturas existentes. Nos foi possível obter conhecimentos mais abrangentes acerca destas questões através de intervenções pedagógicas, contato com livros didáticos e trabalhos desenvolvidos enquanto graduandas do curso de Pedagogia do Centro de Formação de Professores (CFP), da Universidade Federal de Campina Grande (UFCG), nas disciplinas de Currículo e Escola, Educação, Cultura e Diversidade, Educação Inclusiva, Fundamentos e Metodologias do Ensino da História e Fundamentos e Metodologia do Ensino da Geografia, considerando imprescindível a discussão dos estudos sobre estas temáticas. Uma vez que atuaremos em uma sociedade complexa e com grande diversidade de pessoas, dentro e fora do contexto escolar, faz-se importante discutir acerca de um currículo que contemple tais diversidades, levando em consideração os aspectos raciais e culturais, de modo que no ensino haja a representatividade e contribua para a construção da identidade dos sujeitos pertencentes aos variados grupos étnicos.

Desta forma, as práticas existentes em sala de aula e no contexto escolar, tendem a ser contraditórias, pois, segundo os Parâmetros Curriculares Nacionais (1997), a educação é responsável pela construção de fundamentos para a formação de sujeitos para o exercício da cidadania. Porém, a educação, neste contexto, caracteriza-se como reprodutora de uma cultura dominante, atuando na formação de sujeitos submissos e obedientes, onde o professor é responsável pela transmissão e "depósito" de conteúdo.

Considerando este cenário como ineficiente para a valorização da diversidade racial e das relações étnicoraciais, visando a modificação e o desenvolvimento de novas práticas no contexto escolar, é essencial pensar na formação dos profissionais docentes, pois estes devem atuar como problematizadores, mediadores e instigadores, possibilitando assim, a construção de novas práticas educativas e a modificação das então existentes no contexto escolar.

\section{METODOLOGIA}

O presente trabalho tem como metodologia de estudo uma pesquisa bibliográfica que, segundo (PRODANOV; FREITAS, 2013, p. 54), é "[...] elaborada a partir de material já publicado". Como aporte teórico, utilizamos documentos como os PCN de Geografia, a Lei no 10.639/03, a Lei no 9.394/96, que institui as Diretrizes e Bases da Educação Nacional (LDB) e o Parecer CNE/CP no 009/2001, além de autores como Freire (2015), Silva (2005), Callai (2005), Santos (2011) e Rego (2010), que contribuíram efetivamente para a compreensão de como deve desenvolver-se um ensino de Geografia que contemple a diversidade racial e cultural existente.

\section{CURRÍCULO E ESCOLA: A EDUCAÇÃO COMO “ARMA” IDEOLÓGICA}

Refletir acerca da diversidade cultural existente ainda é um grande desafio no contexto educacional. Portanto, nesse texto, discutiremos sobre a Lei oㅜ 10.639/03 e as questões relativas à temática étnicoracial no contexto escolar e a educação para a cidadania, com base no ensino de Geografia para Ensino Fundamental I, a partir de considerações sobre o livro didático, um importante material pedagógico que, infelizmente, na maioria das vezes, segue um modelo hegemônico, contemplando a supremacia de uma cultura sobre as outras, reproduzindo um modelo de homem e de cultura "ideais". 
Os Parâmetros Curriculares Nacionais (PCN) são documentos que visam nortear o ensino dos conteúdos no Ensino Fundamental e, no documento que remete-se a introdução acerca destes, a educação escolar é considerada como

[...] uma prática que tem a possibilidade de criar condições para que todos os alunos desenvolvam suas capacidades e aprendam os conteúdos necessários para construir instrumentos de compreensão da realidade e de participação em relações sociais, políticas e culturais diversificadas e cada vez mais amplas, condições estas fundamentais para o exercício da cidadania na construção de uma sociedade democrática e não excludente. (BRASIL, 1997, p. 33)

Embora este documento aponte a educação como sendo um modo de construir uma "sociedade democrática e não excludente", sabe-se que a classe social dominante e o sistema econômico influenciam diretamente na educação, dificultando, por vezes, que tal objetivo concretize-se.

Partindo da concepção de que o sistema capitalista vigente tem como foco a produção e preocupa-se em formar sujeitos submissos e obedientes para o mercado de trabalho, a escola, como afirma Freire (2015), reproduz um modelo de educação "bancária", em que o professor é o centro do processo educativo e o processo de ensino-aprendizagem é caracterizado pela transmissão de conhecimentos. Nessa dinâmica, a escola torna-se então um local que não oferece espaço para o questionamento, criatividade, construção da autonomia e muito menos para discussões sobre diversidade, já que, para esse sistema, a educação é um instrumento de controle. Assim, ainda na compreensão de Freire (2015, p. 97) "Do ponto de vista dos interesses dominantes, não há dúvida de que a educação deve ser uma prática imobilizadora e ocultadora de verdades", fazendo-se então como um campo de perpetuação dos interesses das classes detentoras do poder.

Ao falar em currículo, este logo é relacionado à escola e, mais especificamente, aos conteúdos por ela apresentados e também aos métodos de ensino, porém, é necessário entender que tudo o que acontece no ambiente escolar também é currículo, visto que em tudo há ensino e aprendizagem. Há, neste caso, a presença do currículo para além da sala de aula, já que existem relações entre as pessoas em todo o ambiente escolar, como também para além dos muros dessa instituição.

A escola é um espaço que trabalha com uma intencionalidade pedagógica e tem a função de oferecer ao educando o acesso ao saber sistematizado. Tal instituição possui um currículo, o qual abrange o conjunto de todos os elementos materiais e imateriais que são utilizados para formar o sujeito. Este currículo é uma construção social, originado através das ideias e ideais da classe hegemônica, das instituições e também dos sujeitos que visam a melhoria da educação. Porém, grande parte dos conteúdos dos livros didáticos são permeados por ideias que favorecem apenas a esta classe dominante. De acordo com Silva (2005, p. 10)

[...] o currículo deve ser visto não apenas como a expressão ou a representação ou o reflexo de interesses sociais determinados, mas também como produzindo identidades e subjetividades sociais determinadas. 0 currículo não apenas representa, ele faz. É preciso reconhecer que a inclusão ou exclusão no currículo tem conexões com a inclusão ou exclusão na sociedade.

Desse modo, o currículo concretiza-se como uma forte arma dessa classe, pois, este é responsável pela formação dos educandos e impõe determinadas ideias como sendo verdadeiras; é este o chamado "currículo oculto", no qual se encobre certos conteúdos e questões propositalmente, para que a formação do educando seja ineficaz em determinados campos do conhecimento.

Embora muitos educadores digam que nada podem fazer em relação a isso, argumentando que o currículo é algo que "vem de cima para baixo", sendo impossível alterá-lo, o que ocorre é a acomodação destes, visto que a própria escola tem a liberdade para fazer seu Projeto Político-Pedagógico (PPP), por exemplo, que, em comunhão com os professores, funcionários, educandos(as) e as famílias, podem assim decidirem sobre os objetivos do ensino da instituição e como estes serão atingidos, pois, conforme complementa Freire (2015, p. 96)

[...] como experiência especificamente humana, a educação é uma forma de intervenção no mundo. Intervenção que, além do conhecimento dos conteúdos bem ou mal ensinados e/ou aprendidos, implica tanto o esforço de reprodução da ideologia dominante quanto o seu desmascaramento. 
A escola, ambiente de encontro de diferentes culturas, etnias e raças, sendo um espaço social utilizado para a oferta do saber sistematizado para as novas gerações e, como implementadora de currículo, que é poder e ideologia, pode também ser utilizada como instrumento de transformação social para os menos favorecidos, para aqueles que estão marginalizados, através de uma educação de qualidade. Visto que o indivíduo forma-se por meio de tudo que chega até ele, sendo a informação a matéria prima para o conhecimento, a escola faz-se também como um local de possibilidades de mudança.

\section{GEOGRAFIA NOS ANOS INICIAIS DO ENSINO FUNDAMENTAL: O ENSINO E A LEI N 10.639/03}

Embora a escola seja uma instituição que permite o acesso ao saber sistematizado, segundo a Lei $\mathrm{n}^{\underline{0}}$ 9.394/96, que institui as Diretrizes e Bases da Educação Nacional (LDB) em seu Art. 2o, Inciso II, a educação "[...] tem por finalidade o pleno desenvolvimento do educando, seu preparo para o exercício da cidadania e sua qualificação para o trabalho", dessa forma, o ensino não pode resumir-se a leitura mecanizada, escrita e acesso aos demais conteúdos escolares, mas deve preocupar-se em ir além das paredes da escola, abrangendo diferentes espaços e buscando contribuir para a formação de sujeitos críticos e conscientes, que exerçam a cidadania. Para isso, faz-se importante que os professores busquem uma constante relação entre os conteúdos apresentados em sala de aula e a realidade na qual os educandos estão inseridos, a partir do conhecimento e respeito à leitura do mundo do educando, considerando, nas práticas educativas, o conhecimento que este carrega consigo, antes de adentrar no contexto escolar.

Tratando-se mais especificamente do ensino de Geografia, Callai (2005, p. 228) aponta que no ensino de tal disciplina:

[...] fazer a leitura do mundo não é fazer uma leitura apenas do mapa, ou pelo mapa, embora ele seja muito importante. É fazer a leitura do mundo da vida, construído cotidianamente e que expressa tanto as nossas utopias, como os limites que nos são postos, sejam eles do âmbito da natureza, sejam do âmbito da sociedade (culturais, políticos, econômicos).

Ensinar Geografia é, portanto, problematizar a realidade dos educandos, compreendendo, por exemplo, os dados estatísticos dentro de um contexto social, econômico, histórico e cultural, ou seja, não basta que estes saibam quais países ou regiões estão com maior ou menor índice de pobreza, mas, é necessário que questionem essas realidades, as condições socioeconômicas e o que acontece dentro daquele determinado contexto. Isto posto, fica evidente que não se deve compreender a Geografia fora do contexto social no qual o educando age e está inserido.

0 já referido documento, que abrange uma introdução acerca dos Parâmetros Curriculares Nacionais (PCN), aponta dez objetivos gerais para o Ensino Fundamental e, entre eles, que o aluno seja capaz de conhecer e valorizar a pluralidade do patrimônio sociocultural brasileiro, bem como aspectos socioculturais de outros povos e nações, posicionando-se contra qualquer discriminação baseada em diferenças culturais, de classe social, de crenças, de sexo, de etnia ou outras características individuais e sociais (BRASIL, 1997, p. 69).

Assim, desde 1997, com os PCN, os conteúdos do Ensino Fundamental já são norteados por um documento que preconiza um ensino voltado à inclusão, ao conhecimento e à valorização da diversidade do povo brasileiro e dos povos pertencentes a outras nações.

Por muito tempo, o currículo escolar e o livro didático vêm constituindo-se conforme uma visão de mundo hegemônica, na qual a cultura de uma classe branca é colocada como superior às demais, a exemplo dos afrodescendentes e indígenas, resultando assim em um ensino reforçador da supremacia de determinados grupos étnicos em detrimento de outros, ausente de representatividade e até fortalecedor do racismo que, para Munanga (1996, apud Cavalleiro, 2003, p. 22)

[...] apresenta-se como uma ideologia que permite o domínio sobre um grupo, por exemplo, judeu, negro ou mulçumano, pautado apenas em atributos negativos imputados a cada um deles. Assim, o racismo atribui a inferioridade a uma raça e está baseado em relações de poder, legitimadas pela cultura dominante

Em vista disso, é evidente a necessidade de um currículo que, ao invés de contribuir para a perpetuação de práticas racistas, contemple a diversidade étnico-racial e colabore para que as práticas educativas desconstruam estereótipos direcionados a estes grupos. 
Atualmente, embora existam algumas conquistas mediante movimentos sociais e reivindicações que visam o reconhecimento e valorização de negros e indígenas no ambiente escolar, na maioria das vezes, há uma preocupação apenas em realizar uma integração por parte das políticas públicas e não de efetivar a inclusão, ou seja, há alguns esforços para que afrodescendentes e indígenas estejam presentes em número na escola, porém, poucas são as ações implementadas para que as crianças pertencentes a estes grupos étnicos sintam-se representadas e valorizadas nestes espaços.

Conforme abordado anteriormente, o currículo é uma construção social, originado através das ideias e ideais da classe hegemônica, das instituições e também dos sujeitos que visam a melhoria da educação. Nesse sentido, cabe destacar o Movimento Negro, uma das organizações engajadas na luta antirracista no Brasil desde 1978 que, mediante constantes reivindicações e movimentos, conquistaram avanços significativos no campo educacional, como, por exemplo, a Lei $n^{\circ} 10.639 / 03$, que inclui no currículo oficial da Rede de Ensino a obrigatoriedade da temática "História e Cultura Afro-Brasileira" que determina

Art. 1ํㅡ A Lei no 9.394, de 20 de dezembro de 1996, passa a vigorar acrescida dos seguintes arts. 26-A, 79-A e 79-B:

"Art. 26-A. Nos estabelecimentos de ensino fundamental e médio, oficiais e particulares, torna-se obrigatório o ensino sobre História e Cultura AfroBrasileira.

$\S 1$ o 0 conteúdo programático a que se refere o caput deste artigo incluirá o estudo da História da África e dos Africanos, a luta dos negros no Brasil, a cultura negra brasileira e o negro na formação da sociedade nacional, resgatando a contribuição do povo negro nas áreas social, econômica e política pertinentes à História do Brasil.

$\S 2^{2}$ Os conteúdos referentes à História e Cultura Afro-Brasileira serão ministrados no âmbito de todo o currículo escolar, em especial nas áreas de Educação Artística e de Literatura e História Brasileiras.

"Art. 79-B. 0 calendário escolar incluirá o dia 20 de novembro como 'Dia Nacional da Consciência Negra'" (BRASIL, 2003)

A Lei no 10.639/03 faz alterações na Lei de Diretrizes e Bases da Educação Nacional (LDB), no 9394/96 que, em seu Art. 26 e 26-A, preconiza que os currículos do Ensino Fundamental devem ser diversificados, contemplando a cultura dos educandos, bem como tornando obrigatório o ensino da história e cultura afro-brasileira e indígena em todo o currículo, tornando-se uma das formas de combater o racismo através da educação, inserindo o negro e a sua cultura no ensino, no currículo e no cotidiano escolar.

No que se refere mais especificamente ao Ensino de Geografia, este proporciona ao educando conhecimentos necessários para que se situe no espaço e no tempo presente, fazendo uma leitura do contexto no qual está inserido e produz mudanças. Porém, sabe-se que pode haver no ensino a hierarquização de culturas e povos, através de uma visão de mundo de determinadas classes. Há, geralmente, uma visão eurocêntrica do mundo, onde os povos europeus e sua cultura são colocados como um "modelo padrão", tendo tais aspectos veiculados através no livro didático, principal instrumento pedagógico norteador do ensino.

A visão de mundo que o livro didático apresenta ao educando pode contribuir para reforçar estereótipos sobre determinados territórios e populações, gerando assim uma leitura de espaço vinculada à questão racial. Tal ideia é destacada por Quijano (2007, apud Santos ,2011, p. 10) quando, ressalta que

[...] quando falamos em "negros", remetemos diretamente à idéia de uma comunalidade, se não biológica, de origem histórico-geográfica: África. Quando falamos em "brancos", o mesmo se repete, com a idéia de uma origem que remete a Europa. 0 mesmo para "índios", associados à América; "amarelos", associados à Ásia. Estes referenciais são absolutamente fruto de distorções, são construções artificiais que servem para produzir visões de mundo, visões do outro, orientar e regular comportamentos e relações [...].

Conforme apontado, a raça, por vezes, passa a ser uma forma de ver determinado local. Quando se fala em "negros", faz-se de imediato uma associação com o continente africano, como se neste não existissem pessoas brancas. Ainda em relação à África, quando mencionada, a visão sobre esta remete-se sempre as savanas, ao tráfico dos negros, a pobreza e a escravidão, deixando de lado o passado desses indivíduos neste local enquanto pessoas de destaque socialmente, quando então alguns eram reis e rainhas e, através 
de duras repressões, foram trazidos para o Brasil e submetidos a condição de escravizados, servindo de mão de obra na lavoura do café e da cana-de-açúcar e vivendo em condições desumanas, sendo impedidos, inclusive, de manifestarem sua cultura e crenças religiosas.

O Brasil desenvolveu-se com base em um regime escravista, sendo então os escravizados negros a base da economia do País. Porém, por muito tempo, perpetuou-se o mito da democracia racial, amplamente divulgado por Gilberto Freyre, na sua obra Casa-Grande \& Senzala, publicada em 1933. De acordo com esta ideia, acreditava-se que no Brasil havia uma convivência pacífica entre as pessoas de todas as raças, negando assim a existência do racismo, que marca o histórico do negro no País. Esta falsa harmonia contribuiu para o atraso nas questões e debates referentes ao combate ao racismo, visto que, quando negava-se a existência de tais práticas de exclusão, não havia então o debate destas. Assim, por meio das lutas do Movimento Negro, a Lei no 10.639/03 insere-se no currículo como um modo de repensar e fazer mudanças no ensino, visando, através da educação, a igualdade na diversidade étnico-racial existente na sociedade e, sendo aplicada no ensino de Geografia, possibilita ao educando uma outra forma de ler o mundo, por meio do estudo da história e cultura afro-brasileira e indígena.

De acordo com Santos (2011), o modo como a Geografia é ensinada pode contribuir para a hierarquia racial, sendo este um fato preocupante, já que, conforme ressaltado anteriormente, a visão de mundo é também concebida através de questões relacionadas à raça. Nesse sentido, é necessário problematizar como os povos indígenas e afro-brasileiros estão sendo retratados nos conteúdos apresentados em sala de aula e no próprio livro didático.

No livro didático, por exemplo, por vezes, índios e negros tem sua presença associada apenas ao passado do Brasil, como se não existissem na atual conjuntura do País. Tal afirmação é sustentada por Rego (2010, p. 64), quando afirma que "[...] na maioria dos casos, pode-se constatar a ausência de negros e indígenas enquanto presenças vivas nas contradições atuais da produção do espaço brasileiro", limitando os negros as páginas sobre o passado de escravidão e os índios "engessados" em um modo atual de vida estereotipado, que os limita a uma visão de sujeitos selvagens, que vivem nas matas e moram em ocas. Tais representações há muitos anos não são capazes de descrever os negros e índios presentes atualmente na sociedade, visto que estes estão presentes nos mais diversos espaços e contextos sociais. Ao passo que as imagens dos negros e indígenas aparecem nos livros didáticos sendo associadas com frequência ao passado de escravidão e exploração, torna-se oculta a sua efetiva contribuição no atual desenvolvimento do Brasil e para além das questões culturais, por exemplo.

Assim, no livro didático, nos seus textos e imagens, a criança afrodescendente vê os povos dos quais descende sempre retratados em condições secundárias, de escravidão, havendo então, uma falta de representatividade e referências que coloquem o povo negro em situações positivas. Repleto de imagens, o livro didático é um instrumento pedagógico capaz de reforçar ou desconstruir estereótipos sobre determinados grupos étnicos. Conforme Rego (2010, p. 66)

As imagens contribuem de maneira decisiva para a construção de uma familiaridade. Assim, aquilo que estiver menos presente nas imagens poderá estar mais distante do afetivo. Representações mais equilibradas quanto às cores do povo brasileiro podem contribuir para uma maior familiaridade deste povo em relação a ele mesmo. Por pouco que seja, essa familiaridade, que torna mais próximo o afeto, pode somar-se às sinergias de uma mudança cultural em curso, para a ultrapassagem das representações que, pela extensão do não dito, facilitam a reprodução das desigualdades sociais.

Assim, o modo como as imagens do livro didático representam determinados grupos étnicos podem contribuir para que haja a ausência de uma referência positiva destes nos materiais didáticos e no currículo, colaborando para que haja a perpetuação de visões negativas em relação a essa parcela da população.

Ainda de acordo com Rego (2010, p. 66) “[...] um livro escolar é um discurso que pode criar contrapontos em relação a outros discursos e, se favorecido pela mediação do professor, estimular elaborações sobre o conhecimento do mundo". Visto isso, destaca-se a importância da formação de professores para a diversidade, já que este é o principal mediador do conhecimento em sala de aula, e pode contribuir efetivamente para um ensino de Geografia que contemple a Lei no 10.639/03.

Segundo o Parecer CNE/CP no 009/2001, que institui as Diretrizes Curriculares Nacionais para a Formação de Professores da Educação Básica, em nível superior, curso de licenciatura, de graduação plena, e tem o objetivo de aperfeiçoar os currículos dos cursos, a formação nos cursos de licenciatura deve 
proporcionar ao graduando o desenvolvimento de competências, de modo que possam "reconhecer e respeitar a diversidade manifestada por seus alunos, em seus aspectos sociais, culturais e físicos, detectando e combatendo todas as formas de discriminação" (BRASIL, 2011, p. 41).

Ainda de acordo com essas diretrizes, os futuros docentes devem considerar a diversidade presente em sala de aula na construção das atividades didático-pedagógicas. Dessa forma, fica explícito que faz-se necessário pensar o currículo da formação docente voltado para uma educação que contemple a diversidade cultural.

A construção da autonomia do graduando também é um aspecto relevante, que deve ser desenvolvido durante o processo de formação, para que o docente tenha consciência de que, por mais que haja "imposição" de uma cultura dominante nos livros didáticos, proporcionando a marginalização de outras, este deve exercer sua autonomia, tanto na análise criteriosa para a escolha dos livros didáticos, como na exposição dos conteúdos e mediação dos conhecimentos.

Dessa forma, é notável que, além do investimento em material pedagógico, como o livro didático, faz-se crucial investir em uma formação de educadores voltada para a diversidade, de modo que o ensino englobe as discussões acerca das múltiplas diferenças existente na sociedade e no contexto escolar, buscando a efetivação de uma prática pedagógica antirracista, que contemple no seu currículo a diversidade racial existente no País.

\section{CONCLUSÕES}

As práticas racistas, embora ainda invisibilizadas, estão presentes na sociedade e no contexto escolar. A escola, como instituição que acolhe sujeitos pertencentes aos mais variados locais e culturas, faz-se então um ponto de encontro para a diversidade, entre estas, a diversidade étnico-racial.

No ensino de Geografia, os conteúdos do livro didático devem ter relação com a realidade do educando, permitindo-o fazer a leitura do mundo em que está inserido e produz mudanças. Porém, esta leitura de mundo deve também possibilitar um olhar positivo acerca da abrangente diversidade cultural existente no nosso País e para além dele. Contudo, é necessário ressaltar que o ensino não é neutro e pode servir como uma forma de hierarquização de culturas, contribuindo para o reforço de estereótipos sobre determinados territórios e populações.

Nesse contexto, sabendo que temas referentes às relações étnico-raciais, história e cultura Afro-brasileira e africanas são invisibilizados, a Lei $\mathrm{n}^{\circ} 10.639 / 03$ surge como uma forma de construir uma sociedade antirracista, por meio da educação. Para que isso ocorra, de fato, faz-se necessário que esta lei efetive-se na prática educativa, pois, ao fechar os olhos, o currículo e os livros para a diversidade racial existente, a escola torna-se uma instituição que contribui para que haja a perpetuação de práticas racistas e de exclusão, reforçando a cultura da classe hegemônica e negando as crianças afrodescendentes e indígenas o direito de ver-se representadas em um ensino que é pra elas, mas, quase nunca, positivamente sobre elas.

\section{REFERÊNCIAS}

[1] Brasil. Parâmetros Curriculares Nacionais: introdução aos parâmetros curriculares nacionais. Brasília : MEC/SEF, 1997. Disponível em: http://portal.mec.gov.br/seb/arquivos/pdf/livro01.pdf. Acesso em: 17 jul. 2018.

[2] Brasil. Parecer CNE/CP 9/2001: Disponível em: http://portal.mec.gov.br/cne/arquivos/pdf/009.pdf. Acesso em: 31 jul. 2018.

[3] Brasil. Presidência da República. Casa Civil. Lei no 9.394/1996. Lei de Diretrizes e Bases da Educação Nacional. Brasília, DF: Diário Oficial 23 dez 1996. Disponível em: http://www.planalto.gov.br/ccivil_03/Leis/L9394.htm. Acesso em: 17 de jul. 2018

[4] Brasil. Lei no 10.639, de 09 de Janeiro, de 2003. Disponível em: http://www.planalto.gov.br/ccivil_03/leis/2003/L10.639.htm. Acesso em: 18 jul. 2018.

[5] Callai, Helena Copetti. Aprendendo a ler o mundo: A geografia nos anos iniciais do ensino fundamental. Cad. Cedes, $\quad$ Campinas, vol.25, n.66, maio/ago. 2005, p. Disponível em: http://www.scielo.br/pdf/ccedes/v25n66/a06v2566.pdf. Acesso em: 17 jul. 2018.

[6] Cavalleiro, Eliane dos Santos. Do silêncio do lar ao silêncio escolar: racismo, preconceito e discriminação na educação infantil. 2. ed - São Paulo Contexto, 2003. 
[7] Freire, Paulo. Pedagogia da autonomia: saberes necessários à prática educativa. 51ํㅡㄹ ed - Rio de Janeiro: Paz e Terra, 2015.

[8] Prodanov, Cleber Cristiano. Freitas, Ernani Cesar de. Metodologia do Trabalho Científico[ recurso eletrônico]: métodos e técnicas da pesquisa e do trabalho acadêmico. $2^{\text {a }}$ ed. Novo Hamburgo: Feevale, 2013. Disponível em: http://www.feevale.br/Comum/midias/8807f05a-14d0-4d5b-b1ad-1538f3aef538/Ebook\%20Metodologia\%20do\%20Trabalho\%20Cientifico.pdf. Acesso em 10 ago. 2018.

[9] Santos, Renato Emerson dos. A Lei 10.639 e o Ensino de Geografia: Construindo uma agenda de pesquisaação. Tamoios, ano VII. $\quad \mathrm{N}^{\circ} 1, \quad 2011$ Disponível em: http://www.epublicacoes.uerj.br/index.php/tamoios/article/view/1702. Acesso em 17 jul. 2018.

[10] Silva, Tomaz Tadeu da. os novos mapas culturais e o lugar do currículo numa paisagem pós moderna. In: Silva, Tomaz Tadeu da; Moreira, Antônio Flávio Barbosa. Territórios contestados. Petrópolis: Vozes, 2004. 


\section{Capítulo 6}

Interculturalidade crítica em processos de aprendizagem e criação em danças Afrorreferenciadas

\section{Emyle Pompeu de Barros Daltro \\ Gerson Carlos Matias de Sousa}

Resumo: Por meio do projeto de extensão Grande Roda: africanidades, ancestralidades e interculturalidade em movimentos, vinculado aos cursos de Licenciatura e Bacharelado em Dança da Universidade Federal do Ceará - UFC, foram realizados, durante o ano de 2017, cursos que nos permitiram vivenciar e pesquisar danças afrorreferenciadas. Os cursos estiveram voltados a professores de arte da educação básica, artistas, pesquisadores, ativistas, estudantes e professores universitários, além de interessados da comunidade em geral. Neles, conexões foram potencializadas e o respeito - olhar horizontalmente para o outro, levando-o seriamente em consideração - foi requisitado. Nossa comunicação tem como objetivo compartilhar o processo de realização de um desses cursos, Corporeidades afroancestrais na cena contemporânea - conduzido por Gerson Moreno -, e o seu legado para tecermos proposições interculturais de ensino/aprendizagem e de criação em dança, de modo crítico e articulado a referências "outras" que também nos tingem e nos tecem como indoafrolatinoamericanos. Consideramos urgente que tais referências sejam visibilizadas e valorizadas e que possam ressoar em/com nossas danças, tanto cênicas, como cotidianas, de modo a experimentarmos como elas podem favorecer relações mais simétricas entre nós.

Palavras-chave: ensino/aprendizagem e criação em dança, danças afrorreferenciadas, interculturalidade crítica. 


\section{INTRODUÇÃO}

Por meio do projeto de extensão Grande Roda: africanidades, ancestralidades e interculturalidade em movimentos, foram realizados cursos, durante o ano de 2017, em três diferentes locais da cidade de Fortaleza, que nos permitiram vivenciar e pesquisar corporeidades e danças afrorreferenciadas.

A equipe do projeto foi composta por Emyle Daltro, professora adjunta dos cursos de Bacharelado e Licenciatura em Dança da UFC, que teve a função de coordenar o projeto; por Sandra Petit, cubana radicada no Brasil, professora da Faculdade de Educação da UFC, coordenadora do Núcleo de Africanidades Cearenses e propositora do método da Pretagogia; pelos além de educadores, também dançarinos, pesquisadores e coreógrafos Gerson Moreno - que há três décadas trabalha com dança cênica, com um percurso fortemente marcado pelas africanidades, tendo como sede a cidade de Itapipoca, interior do Ceará; Rubéns Lopes, Jorge Luiz Alves de Lima (Loly Pop) e Luís Alexandre Pereira da Silva; e pelo percussionista da Guiné Bissau Trindade Gomes Nanque que, nesse ano, era estudante de Letras da Universidade da Integração Internacional da Lusofonia Afro-Brasileira (Unilab), na cidade de Redenção, Ceará e hoje já é graduado.

Nesses cursos, conexões foram potencializadas e o respeito - olhar horizontalmente para o outro, levandoo seriamente em consideração - foi requisitado. "Ao olhar nos olhos, enxergar o outro, a nós mesmos, ao darmos as mãos, abraçarmos com carinho e afeto uns aos outros, nos libertamos. ${ }^{5 \text { " }}$

Neste texto, estaremos a compartilhar um pouco do processo de realização de um desses cursos, Corporeidades afroancestrais na cena contemporânea - conduzido por Gerson Moreno -, e o seu legado para tecermos proposições interculturais de ensino/aprendizagem ${ }^{6}$ e de criação em dança, de modo crítico e articulado a referências "outras" que também nos tingem e nos tecem como indoafrolatinoamericanos. Consideramos urgente que tais referências sejam visibilizadas, valorizadas, acolhidas e que possam ressoar em/com nossas danças, tanto cênicas, como cotidianas, de modo a experimentarmos como essas referências "outras" podem favorecer relações mais simétricas entre nós. Importante pontuar que dialogamos com o termo ancestralidade como uma noção que remete ao passado, mas se encontra vibrando no presente e pode compor modos de vida mais promissores no/com o futuro. De acordo com Catherine Walsh (2009), falar de modos "outros" não é se referir a alternativas dentro de uma mesma razão moderno-ocidental-colonial, mas refere-se a um lugar de vida que recusa a universalidade abstrata e que é marcado pela diferença colonial, que ganha ênfase no contexto da diferença cultural. Levar em conta a diferença colonial de que fala Catherine Walsh (2009) solicita que nos empenhemos em colocar em prática a "interculturalidade crítica", em contraposição ao multiculturalismo ou ao que Walsh chama de "interculturalidade funcional". Para essa autora:

0 enfoque e a prática que se desprende da interculturalidade crítica não é funcional para o modelo de sociedade vigente, mas um sério questionador dele. Enquanto a interculturalidade funcional assume a diversidade cultural como eixo central, apontando seu reconhecimento e inclusão dentro da sociedade e do Estado nacionais (uni nacionais por prática e concepção) e deixando de fora os dispositivos e padrões de poder institucional-estrutural - que mantêm a desigualdade -, a interculturalidade crítica parte do problema do poder, seu padrão de racialização e da diferença (colonial, não simplesmente cultural) que foi construída em função disso. 0 interculturalismo funcional responde e é parte dos interesses e necessidades das instituições sociais; a interculturalidade crítica, pelo contrário, é uma construção de e a partir das pessoas que sofreram uma histórica submissão e subalternização. (2009, p. 21-22)

\footnotetext{
${ }^{5}$ Relato de Kênia Pinheiro sobre sua vivência no curso Corporeidades afroancestrais na cena contemporânea.

${ }^{6}$ Escrevemos ensino/aprendizagem com essa barra inclinada entre os termos, para provocar que pensemos ensino e aprendizagem de modo intrincado, sendo constituídos mutuamente na relação.
} 
De uma maneira ampla, Walsh propõe a interculturalidade crítica como ferramenta pedagógica que:

[...] questiona continuamente a racialização, subalternização, inferiorização e seus padrões de poder, visibiliza maneiras diferentes de ser, viver e saber e busca o desenvolvimento e criação de compreensões e condições que não só articulam e fazem dialogar as diferenças num marco de legitimidade, dignidade, igualdade, equidade e respeito, mas que - ao mesmo tempo - alentam a criação de modos "outros" - de pensar, ser, estar, aprender, ensinar, sonhar e viver que cruzam fronteiras. A interculturalidade crítica e a decolonialidade, nesse sentido, são projetos, processos e lutas que se entrecruzam conceitualmente e pedagogicamente, alentando forças, iniciativas e perspectivas éticas que fazem questionar, transformar, sacudir, rearticular e construir. (2009, p. 25)

Desde quando o colonialismo foi instaurado, diversos modos de oposição a essa política e de luta pela descolonização passaram a existir. Esses movimentos, práticas e pensamentos contrários marcam as histórias de todos os povos envolvidos nas relações de dominação colonial. Hoje, falamos em colonialidade e decolonialidade, pois em termos jurídico-políticos o colonialismo não mais existe, mas resta-nos a colonialidade... Desde o enfoque decolonial:

[...] o capitalismo global contemporâneo ressignifica, em um formato pósmoderno, as exclusões provocadas pelas hierarquias epistêmicas, espirituais, raciais/étnicas e de gênero/sexualidade implantadas pela modernidade. Deste modo, as estruturas de longa duração formadas durante os séculos XVI e XVII continuam desempenhando um papel importante no presente [...] Como resultado, o mundo de começos do século XXI necessita uma decolonialidade que complemente a descolonização levada a cabo nos séculos XIX e XX. Ao contrário dessa descolonização, a decolonialidade é um processo de ressignificação a longo prazo que não se pode reduzir a um acontecimento jurídico-político. (CASTRO-GÓMEZ; GROSFOGUEL, 2007, p.14 e 17, grifos dos autores e tradução nossa)

Interessante percebermos corporeidades decoloniais emergindo de regiões fronteiriças, colocadas à margem de um poder central, ou seja, das periferias de grandes cidades, do interior dos estados, de movimentos sociais, artísticos, ligados a manifestações religiosas minoritárias, entre outros. Colocamo-nos lado a lado de vários desses agentes sociais que integraram o curso de extensão Corporeidades afroancestrais na cena contemporânea e, nesse dançar junto, afetamo-nos mutuamente.

\section{CORPOREIDADES AFROANCESTRAIS NA CENA CONTEMPORÂNEA}

O curso proporcionou vivências que se articularam principalmente aos arquétipos dos orixás afrobrasileiros, os caboclos, pretos velhos e encantados, seus mitos, simbologias e corporeidades ancestrais, tendo nas singularidades de cada corpo dançante as condições para a realização de investigações em danças e dramaturgias afrorreferenciadas, para experimentos sensoriais/ritualísticos e para a criação/composição coletiva em dança.

A partir do mês de setembro de 2017, a proposta do curso - que teve início em maio desse mesmo ano, com a abertura de uma primeira turma - foi desdobrada e uma segunda turma foi aberta, tornando-se um laboratório de criação artística e abrangendo participantes que continuaram, vindos do processo iniciado no primeiro semestre, como também novos integrantes, já com alguma inserção, pesquisa ou atuação alinhada com a proposta do laboratório. Ao todo, a proposta formativa teve carga horária de 80 horas.

O curso e o laboratório de criação articularam movimentos, músicas, cantos, diálogos, relatos orais e escritos, textos, fotos e registros videográficos num movimento favorecedor de reposicionamentos. Com quem/o que e onde preciso estar para ver as coisas diferentemente de como elas estão hegemonicamente organizadas? Parece-nos que esses reposicionamentos tendem a ocorrer quando todo tipo de reducionismo e também distanciamento começa a ceder lugar a um processo de conhecer o outro e percebê-lo em nós, processo este que vai sendo tecido com os corpos, nas vivências que vão sendo constituídas. Quando experimentamos a dança do outro com todo o corpo, de modo afetuoso, intenso, com entrega, estamos num exercício de negociação entre essa nova corporeidade com as corporeidades que nos constituem, favorecendo a tomada de posições diferentes. 
Dançar pode nos fazer pensar e problematizar quem somos e quem queremos ser? Dançando, podemos performar esse/a humano/a "outro/a"?

No curso e no laboratório, ganharam destaques danças que surgiram a partir de elementos das religiões afro-brasileiras como o candomblé e a umbanda, historicamente marginalizadas. Diversos movimentos, energias, estados foram mobilizados, conectando-nos às figuras dos orixás e de outras entidades da religiosidade afro-brasileira.

Com Exú dançamos de modo viril, sexuado, debochado, prazeroso, perspicaz, às vezes tenso, abrindo caminhos de comunicação com os outros orixás...

Com Ogum, movimentos precisos, fortes e cortantes foram experimentados, o olhar direto, o enfrentamento, a luta incitaram os corpos dançantes.

Com Oxóssi, dançamos com atenção a tudo o que nos cerca, às vezes ficamos à espreita, ora estamos caça, ora caçador. Pisamos com leveza e firmeza, olhos, ouvidos, todos os sentidos atentos, ligados, conectados. Mira, flecha, bicho, grito, sonoridades, floresta, folha, chão, morte, húmus, vida.

Com Oxum dançamos o amor, a beleza, sentimos a frescura das águas a conduzir nosso mover-se, assim como a fertilidade feminina apoderar-se de nós por inteiro...

Com Iemanjá, dançamos acolhendo o outro, como boas mães o sabem e o fazem tão bem... Generosidade no gesto. Praticamos diversos movimentos com os braços que, ondulantes, sobem, descem, abraçam, afagam...

Com Oxalá exercitamos o andamento lento de nossos movimentos, o caminhar de modo curvado, o uso das mãos de maneira apaziguadora... Amor, pai, sabedoria, ancião, criação...

A partir dessas experimentações, realizadas ao longo do ano, constituíram-se jogos coreográficos que, articulados a ritos cênicos, compuseram o trabalho de dança Cabeças Sagradas, que celebra encontros, aprendizados, inquietações, buscas e achados em coletivo.

\section{CABEÇAS SAGRADAS}

Configura-se como uma compartilha de dança que agrega participantes distintos e plurais provindos de experiências diversas em dança, teatro, música, educação, religiosidade/espiritualidade e militância negra nos movimentos sociais.

Seu principal material de trabalho são cada um dos dançarinos/criadores e suas potências singulares. Suas cabeças emanam anseios, implicações e mitos pessoais. Nas/com as cabeças estão os Orixás, as forças criativas e transformadoras da natureza e do cosmos. Cabeça não reduzida ao lugar da Razão e do pensamento compartimentalizado, dualista, ocidentalizado, mas como abrigo das potências de criação e libertação, resguardo do espírito, morada dos ancestrais e de seus conhecimentos, portanto lugar da intuição e sensibilidade apuradas, da decisão e da autonomia criativa.

Processos interativos, circulares e ritualísticos mobilizam esse percurso coreográfico, as construções estéticas e a proposta dramatúrgica do trabalho de dança. 0 público é convidado a vivenciar com os dançarinos as emanações do axé7 por meio de saudações, compartilha de afetos e travessias. Uma tigela de barro abriga um búzio e água que banha os dançantes, num processo de aflorar o cuidado afetuoso de uns com os outros. Nesse fluxo, materializam-se, de variados tamanhos, tempos e pesos, uma diversidade de seres, sons, cheiros, instintos, desejos, lugares, divindades... Dançam Oguns, Oxóssis, Oxuns, Nanãs e Oxalás tecendo corporeidades no tempo presente do aqui e agora. Instauram-se sete assentamentos, sete pontos de partida, passagens e chegadas, sete territórios de habitação, interferência e transformação, uma roda sagrada se faz. Laroyê Exú puxa cordões, algazarras e traquinagens, convida o mundo para assumir as suas contradições e conflitos, impulsiona a roda para que ela ganhe outras dimensões, estados e texturas, conduz os seres para a encruzilhada... 0 encontro-abraço de todos esses dançantes marca o momento do recomeçar, com saudações que exprimem o profundo respeito por cada agente, pelas materialidades/socialidades presentes nessa grande compartilha.

\footnotetext{
7 Na língua iorubá, axé significa poder, energia ou força presentes em cada ser ou em cada coisa. Nas religiões afrobrasileiras, o termo faz alusão à energia sagrada dos orixás. Dentro e fora do contexto religioso, axé é uma saudação utilizada para desejar votos de felicidade e boas energias.
} 
Cabeças Sagradas é vivência que tece estados psicofísicos, movimentos e relações em dança, com corpos/espaços/tempos que se conectam intensamente. Afroancestralidades se articulam ao sagrado - ao que é profundamente respeitável -, ao que nos une. Axé!!!

\section{TECENDO ALGUMAS CONSIDERAÇÕES}

Ao longo do processo de ensino/aprendizagem e criação em dança que o projeto Grande Roda nos proporcionou, pudemos perceber que para nos afetarmos com o que se difere de nós mesmos, é preciso experimentação continuada, é necessário convivermos e registrarmos, de diversas maneiras, as diferenças experimentadas nessas vivências para se inventar - no sentido de colocar problemas, como propõe Virgínia Kastrup (2007) -, criar um corpo que se abre, que ressoa, aprende e pode se aliar a outros. Isso pode ser feito por meio da dança, do dançar essas diferenças, de modo a constituir histórias, mundos em que conexões, mesmo que parciais, sejam celebradas, desejadas e possam ser feitas e refeitas em condições simétricas, horizontais. É nesse sentido que articulamos ao nosso projeto a noção de "interculturalidade crítica", que nos orientou nos processos de ensino/aprendizagem e de criação em dança que conduzimos ao longo desse projeto de extensão. Tais processos possibilitaram a formação de grupos de pessoas que dançam para celebrar a vida, o estar junto; que entendem e fazem dança como ato social, artístico, político, de resistência e transformação.

Importante pontuar que a imbricação entre estético e sagrado é algo observável nos mais diversos cultos e rituais de cunho religioso, mas quando se retira do contexto sagrado os elementos estéticos que constituem esses cultos, ritos etc., corremos o risco de incorrer em profanação. Diversos são os artistas (de diferentes campos das artes, locais e épocas) que assumiram esse risco e decidiram lidar com o sagrado em seus processos de criação. Essa discussão é longa e muitas questões, inclusive sobre os limites da arte, permanecem em aberto quando o sagrado torna-se tema de pesquisa e dispositivo para a criação artística. Nesse sentido, o curso de extensão e a criação cênica Cabeças Sagradas possibilitaram a lida com alguns elementos do legado simbólico africano - que na operação colonialista foi restringido ao âmbito do éticoreligioso - no campo da pesquisa em dança, na área das artes, o que costuma ser acompanhado de tensões que, ao nosso entender, é muito importante que assumamos, sempre com muito respeito em relação aos materiais sagrados com os quais estamos aprendendo e criando, principalmente porque os saberes religiosos afro-brasileiros estão impregnados de uma dimensão política para a qual nos chama a atenção Muniz Sodré:

Dos símbolos, dos desdobramentos culturais de um paradigma (a Arkhé africana, manifestada num sistema axiológico em que se articulam valores éticos, cerimônias, sacrifícios e hierarquia), emergem representações capazes de atuar como instrumentos dinâmicos no jogo social de estratos historicamente à margem da cidadania plena. A política pode ser parceira nesse jogo. Não certamente a política que se define como fenômeno de Estado (política partidária, política social etc.) e sim a prática de organização da reciprocidade dos seres diferentes em comunidade, ou seja, política como prática de estar junto, ao lado da luta pela inclusão, no mundo comum, de excluídos históricos. Um agir político grupal lastreia o pacto simbólico implícito nas formas de organização comunitária dos descendentes de africanos. É uma política que não costuma aparecer nas lentes etnológicas e se faz visível na mobilização de recursos para a consolidação das alianças internas ao grupo e nas táticas de aproximação com a sociedade global hegemônica (2017, p. 172).

Consideramos que os legados afrorreferenciados que foram/são conectados à dimensão do sagrado podem agir a favor da decolonialidade do saber eurocentrado (universalizado, hegemônico), apresentando ricas contribuições para a pesquisa e a produção na área das artes e da educação. Também nos levam a repensar nossa produção artística nesse processo de busca por potencialização a partir de referências "outras", convocando-nos a voltarmos nossa atenção e estudos para conhecimentos tradicionais hábeis em resistir a uma epistemologia dominante. As artes, na sua lida com a produção de sentidos, podem provocar diálogos entre diferentes estéticas, bem como reflexões e disseminação de conhecimentos que valorizem a dimensão ético-política da religiosidade afro-brasileira, fortalecendo processos de empoderamento de seus agentes e de coletivos artísticos ou não, marginalizados e inferiorizados. As danças afrorreferenciadas podem favorecer a tessitura de produções artísticas e de processos de ensino/aprendizagem do/no tempo presente, que reinventem o passado e componham modos de vida mais promissores no/com o futuro. 


\section{REFERÊNCIAS}

[1] Castro-Gómez, Santiago; Grosfoguel, Ramón (orgs). El giro decolonial: reflexiones para una diversidad epistémica más allá del capitalismo global. Bogotá: Siglo del Hombre Editores; Universidad Central, Instituto de Estudios Sociales Contemporáneos y Pontificia Universidad Javeriana, Instituto Pensar, 2007.

[2] Daltro, Emyle P. B. Corporrelacionalidades e coletivo na composição e aprendizagem inventivas em dança. 2014. 246 f. Tese (Doutorado em Arte). Instituto de Artes, Programa de Pós-Graduação em Arte, Universidade de Brasília, Brasília, DF, 2014.

[3] Kastrup, Virgínia. A invenção de si e do mundo: uma introdução do tempo e do coletivo no estudo da cognição. Belo Horizonte: Autêntica, 2007.

[4] Petit, Sandra Haydée. Pretagogia: pertencimento, corpo-dança afroancestral e tradição oral Africana na formação de professoras e professores. Fortaleza: Ed. UECE, 2015.

[5] Sodré, Muniz. Pensar Nagô. Petrópolis, RJ: Vozes, 2017.

[6] Walsh, Catherine. Interculturalidade crítica e pedagogia decolonial: in-surgir, re-existir e re-viver. In: Candau, Vera Maria (Org.). Educação intercultural na América Latina: entre concepções, tensões e propostas. Rio de Janeiro: 7 Letras, pp. 12-43, 2009. 


\section{Capítulo7}

\section{O currículo e a cultura Afro-Brasileira}

\section{Leticia Priscila Azevedo de Sousa}

\section{Luzia Areal Barros}

\section{Maria de Fatima Andrade Costa Henriques}

Resumo: 0 artigo analisa a aplicação da Lei 10.639/03 que versa sobre a obrigatoriedade da temática "História e Cultura Afro-Brasileira" nos currículos. Apresenta a conceituação de cultura e currículo estabelecendo um paralelo entre os dois e, destacando que o currículo deve contemplar dentre outros itens a construção da identidade dos educandos. Neste sentido, busca avaliar os conhecimentos dos docentes sobre o tema. A metodologia utilizada foi centrada em análise documental com ênfase em questões que versam sobre a aplicabilidade da lei, o domínio dos docentes sobre o assunto, a oferta de instrumentos/materiais de apoio para ensino do conteúdo configurando-se, portanto, em pesquisa qualitativa. Conclui-se que a lei ainda não foi aplicada em sua totalidade por questões diversas como preconceito, falta de interesse dos docentes sobre o tema, pouco material de apoio disponível com conteúdo efetivamente relevante.

Palavras - chaves: Currículo; Cultura afro-brasileira; Lei 10.639/03. 


\section{INTRODUÇÃO}

A Lei de Diretrizes e Bases da Educação Nacional (LDBEN) estabelece que deve-se considerar a diversidade étnico-racial como um dos princípios básicos do ensino. Tal princípio evidencia que é papel da escola estabelecer um paralelo entre o conteúdo programático e a realidade do seu educando e, dos professores, contribuir como dinamizadores do conteúdo proposto no currículo escolar, promovendo a valorização da identidade dos seus educandos.

Neste sentido, foi criada no ano de 2003 a lei 10.639 que versa sobre a inserção da história e cultura afrobrasileira no currículo escolar e visa ressaltar a importância desse elemento para a formação do povo brasileiro. Buscando ser um instrumento facilitador para a difusão dessa cultura que muitas vezes foi preterida e discriminada, a Lei demonstra esforço em quebrar paradigmas de preconceito conscientizando aos alunos sobre suas origens.

Após mais de uma década de sua homologação, questiona-se como tem sido feita a inserção da Lei no cotidiano dos educandos. Nesse sentido é mister perguntar se a formação dos professores tem sido adequada a essa nova demanda educacional? E mais, que tipo de capacitação e de material didático o Ministério da Educação (MEC) tem ofertado para que esse conteúdo seja de fato posto em prática?

Com uma população em que mais da metade dos cidadãos se declara negra ou parda, é de suma importância para a identidade e autoestima dos discentes que a cultura afro-brasileira seja abordada de uma maneira interdisciplinar e de maneira mais abrangente do que se tem apresentado até a criação da lei 10.639/03. A construção da identidade dos educandos vai refletir na cidadania e na aceitação da diversidade cultural.

\section{A IMPORTÂNCIA DA LEI 10.639/03 NOS CURRÍCULOS}

Como entender a cultura na concepção do currículo sem levar em consideração as diferentes realidades que permeiam a construção da sociedade brasileira? Pode-se dizer que a pluralidade é um fator que deve ser levado em consideração, pois verifica-se a existência de um imenso "arco íris" de diversidade cultural que nos faz diferentes em realidades, mas nos possibilita um crescimento inimaginável. Somos indivíduos que trocamos diariamente nossos saberes e visão de mundo fazendo da aquisição de conhecimento uma via de mão dupla.

Estabelecendo um comparativo com a Lei de Diretrizes e Bases (LDBEN) e a Lei número 10.639/03 que inclui no currículo oficial da Rede de Ensino a obrigatoriedade da temática "História e Cultura AfroBrasileira" percebe-se a importância de abordar a identidade e as raízes históricas no nosso currículo escolar.

Com base no conceito de que

"cultura é o conjunto de formas e expressões que caracterizarão no tempo uma sociedade determinada. Pelo conjunto de formas e expressões, entende-se e inclui os costumes, crenças, práticas comuns, regras, normas, códigos, vestimentas, religião, rituais e maneiras de ser que predominam na maioria das pessoas que a integram". (CONCEITO, 2015)

Ou ainda que pode-se explicar a cultura como "os aspectos aprendidos que o ser humano, em contato social, adquire ao longo de sua convivência." (Rodrigues, 2015) percebe-se que a cultura está intrinsecamente inserida no currículo pedagógico.

Currículo é o documento que reflete o planejamento do conteúdo básico a ser transmitido no ambiente escolar e como norteador no processo de ensino-aprendizagem apropria e desapropria os saberes. Precisa possuir vida, pois apesar das marcas comuns, o aprendizado final é individualizado.

"Nesse contexto, o estudo do currículo deve atender a quatro pressupostos básicos: oferecer uma visão da cultura que as escolas transmitem tanto em sua dimensão oculta quanto na manifesta; ser entendido como um processo historicamente construído, não apenas como algo a ser reproduzido, mas a ser modificado e reconstruído; promover a interação entre teoria e prática; ser um projeto cultural, com flexibilidade para que os professores intervenham nele". (LIMA, 2006, p.147) 
Pode-se afirmar de fato que os professores fazem esta intervenção? Ou simplesmente o currículo ainda é o instrumento de poder do Estado? Respondendo a estes questionamentos, nota-se uma "falsa" mudança de paradigmas que induz a acreditar que existe uma livre contribuição dos docentes. A não participação destes "sujeitos" nesta escolha do currículo contribui de forma negativa, porque estes "atores" seriam os responsáveis preparados para transmitir o que é a realidade cultural dos alunos.

Ao selecionar o conteúdo de um currículo o educador exercita um poder de escolha afirmando assim a conexão entre este poder, o saber e a identidade. A escola deve fazer o papel a que se propõe, ou pelo menos do que se espera dela e que seja também um complemento para estimular o desenvolver pessoal do aluno, sua identidade e sua realidade. 0 currículo deve abarcar esses saberes pessoais que "intimamente" estão retratando sua visão de mundo. Muitas vezes o currículo não permite que o aluno expresse sua identidade, por apresentar conceitos pré-estabelecidos que cerceie a autonomia de pensamento e criação.

Desta forma, em análise a referida Lei, evidencia-se o quão importante é a inserção da cultura afrobrasileira no currículo, cabendo uma reflexão da lei citada, visto que essa cultura já fazia parte da realidade de nossa sociedade, sendo muitas vezes preterida.

Mesmo tendo mais de uma década de existência, a Lei ainda não está sendo aplicada num percentual representativo evidenciando seus entraves.

Um dos obstáculos observáveis em relação a esse fato é a falta de capacitação dos professores que não se interessam pela temática, apesar da oferta de cursos gratuitos, inclusive online, oferecidos pelo MEC. Mais fatores que podemos destacar: 0 preconceito arraigado na sociedade brasileira que é refletido nas instituições educativas, pois muitos elementos da cultura afro-brasileira são estigmatizados como de pouca representatividade em conteúdos e desinteressante; A falta de material didático para suporte e embasamento do conteúdo, visto que somente no ano de 2012 foi disponibilizada pelo MEC uma coleção em oito volumes que versa sobre a História Geral da África e que foi elaborado em parceria com a Organização das Nações Unidas para Educação, Ciência e Cultura (Unesco) cujo conteúdo abrange história, cultura, economia, política e arte.

O entrave para a aplicação da lei é tão evidente que o advogado Humberto Adami, ex-presidente do Instituto da Advocacia Racial e Ambiental (IARA) ajuizou uma ação em 2008 na 12ạ. Vara da Fazenda Pública, determinando a apresentação dos currículos das dez maiores escolas particulares do Rio de Janeiro, assim como das redes estaduais e municipais da capital, para verificar o cumprimento da Lei 10.639 de 2003 obtendo um parecer favorável somente no ano de 2014.

Muitas vezes é preciso repensar as raízes, crenças e hábitos, para que o educando não perca suas origens, e aqui vale lembrar que essa realidade, é aplicável a todo o povo brasileiro, pois sua origem veio da miscigenação de raças. Muito se tem presenciado a intolerância religiosa, não permitindo, a transmissão de conhecimento dos contos africanos ensinados nos terreiros de Candomblé, Umbanda, Quimbanda e demais.

As escolas se restringem a escolher de forma conveniente apenas alguns elementos das manifestações culturais herdadas dos africanos que aqui chegaram para construir a maior parte da economia brasileira da época, destarte apresentam somente a escravidão, a feijoada e a capoeira como influências da cultura afro-brasileira em detrimentos dos demais elementos que enriquecem a nossa sociedade.

\section{CONCLUSÃO}

Apesar de todos os ordenamentos legais preconizados pelo Ministério da Educação das estratégias apontadas no sentido de incluir questões que versam sobre o tema, percebe-se um longo caminho a ser percorrido para que o propósito da Lei seja efetivamente alcançado nos currículos da educação básica. Essa não é uma conclusão distante de compreensão, pois basta observar que a referida Lei não contempla todo o processo de ensino-aprendizagem, pois não incluiu a educação infantil que é base para construção do indivíduo.

Ressalta-se ainda que ao especificar as áreas que deverão ministrar tal conteúdo ela restringe sua atuação multidisciplinar, pois a influencia que os povos africanos deixaram de legado à sociedade brasileira não ficou restrito a economia ou as manifestações culturais, mas vão muito além delas e aqui vale lembrar que nisso existe inclusive um legado triste que é a do preconceito, diante dessa constatação não pode esse debate ficar atrelado apenas às áreas de educação Artística, Literatura e História abordar essa temática. 
Por fim, se o currículo se propõe a mudar comportamento, diminuir as diferenças e enriquecer o indivíduo, contribuindo de fato para construção de sua identidade, isso corrobora a necessidade de efetiva implementação desse conteúdo.

\section{REFERENCIAS}

[1] Adami, Humberto. Escolas do Rio vão ter de provar que cumprem lei de História da África e cultura AfroBrasileira. 2014. Disponível em: https://mamapress.wordpress.com/2014/01/31/escolas-do-rio-vao-ter-de-provarque-cumprem-lei-de-historia-da-africa-e-cultura-afrobrasileira/. Acesso em: 27 jul. 2016.

[2] Amorim, Rovênia. Cultura e História africanas chegam às escolas públicas. 2011. Disponível em: http://portal.mec.gov.br/component/content/?view=211:noticias\&id=17259: cultura-e-historia-africanas-chegam-asescolas-publicas. Acesso em: 27 jul. 2016.

[3] Brasil. Presidência da República. Lei no 10639, de 9 de janeiro de 2003. Altera a Lei no 9.394, de 20 de dezembro de 1996, que estabelece as diretrizes e bases da educação nacional, para incluir no currículo oficial da Rede de Ensino a obrigatoriedade da temática "História e Cultura AfroBrasileira", e dá outras providências. Lei № 10.639, de 9 de Janeiro de 2003. Disponível em: http://www.planalto.gov.br/ccivil_03/leis/2003/L10.639.htm. Acesso em: 25 jul. 2016.

[4] Carvalho, Leandro. Lei 10.639/03 e o ensino da história e cultura Afro-Brasileira e Africana. 2015. Disponível em: https://educador.brasilescola.uol.com.br/estrategias-ensino/lei-10639-03-ensino-historia-cultura-afrobrasileira-africana.htm. Acesso em: 24 jul. 2016.

[5] Castro, Fernanda. Década $2013 . \quad$ Disponível em: http://revistaeducacao.uol.com.br/textos/200/decada-encoberta-302321-1.asp. Acesso em: 25 jul. 2016.

[6] Conceito de Cultura. 2015. Disponível em: https://queconceito.com.br/cultura . Acesso em: 26 jul. 2016.

[7] Justiça cobra o ensino de história da África. 2014 . Disponível em: http://www.brasil247.com/pt/247/favela247/128861/Justiça-cobra-o-ensino-de-História-daÁfrica.htm . Acesso em: 02 ago. 2016.

[8] Lima, Marceline; Lemos, Maria de Fátima; Anaya, Viviane. Currículo escolar e construção cultural: uma análise prática. Dialogia, São Paulo, v. 5, p.141-151, 30 out. 2006. Mensal.

[9] Rodrigues, Lucas de Oliveira. Cultura. $2015 . \quad$ Disponível em: https://mundoeducacao.bol.uol.com.br/sociologia/conceito-cultura.htm. Acesso em: 27 jul. 2016. 


\section{Capítulo 8}

\section{Relações de dignidade em contexto de diversidade: Um estudo na feira central de Campina Grande}

\section{Francilene Araújo de Morais \\ Maria Luisa Mendes Teixeira}

Resumo: A dignidade da integridade abrange aspectos inatos e adquiridos no contexto social, podendo ser construída nos mais diversificados ambientes, mediante relações interpessoais e grupais. Desse modo, optou-se em estudar o mercado da feira central de Campina Grande, no que se refere a compreender como se estabelecem as relações de dignidade entre feirantes e clientes, bem como identificar a concepção de feirante e cliente digno. A pesquisa qualitativa utilizou um roteiro de entrevista aplicado a 35 sujeitos: 25 feirantes e 10 clientes, de ambos os sexos, de faixa etária e nível de escolaridade variado. Após transcritas e analisadas, as falas dos entrevistados foram agrupadas em categorias, levando-se em consideração a semelhança de conteúdo e objetivos pré-estabelecidos. Os resultados mostraram que dignidade humana relacionase a valores morais, educação, sentimentos, distinção e benevolência. Os significados de feirante digno e cliente digno correspondem à dignidade relativa ao papel. 0 múltiplo significado de dignidade humana é previsto na literatura e, os significados de dignidade relacionada ao papel específico, pressupõem o significado de dignidade humana. Este artigo inova ao gerar conhecimentos sobre o relacionamento entre feirantes e clientes. Limites e Sugestões de novos estudos são apresentados.

Palavras- chave: Dignidade. Diversidade. Feirante. Cliente. 


\section{INTRODUÇÃO}

Uma maneira pela qual se pode começar a discussão da dignidade humana consiste em abordá-la sob as perspectivas: adquirida e/ou inata. Enquanto dignidade adquirida, pode ser concebida como sendo de natureza sociopolítica ou de mérito e também de status moral. Ambas são adquiridas no contexto social. Já a concepção de dignidade como valor intrínseco tem um sentido eminentemente inato, no que diz respeito à natureza humana. $\mathrm{E}$ a concepção de dignidade como integridade abrange tanto os aspectos inatos quanto adquiridos. (TADD,VANLAERE,GASTMANS, 2010); NORDENFELT, 2003; NORDENFELT, 2004).

Essa concepção de dignidade, a da integridade, tem o sentido de dignidade social abordado por Jacobson (2009) e abrange dois tipos de dignidade: a do self e a relacional. A dignidade do self corresponde ao autorespeito e autovalor, podendo ser identificada nas relações, mediante características de confiança e de integridade. A dignidade relacional é construída nas interações entre indivíduos, grupos e sociedade e refere-se à presença de respeito e de valorização em direção ao outro, podendo ser expressa mediante comportamentos individuais e coletivos (JACOBSON, 2007, 2009).

Considerando que a dignidade da pessoa humana tem sido alvo de estudo por profissionais de várias áreas do saber, tais como: educação, direito, saúde, psicologia, administração, entre outros (ARAÚJO, 2013), tanto em contextos organizacionais quanto em situações da vida cotidiana, optou-se em estudar o mercado da feira livre.

Desde a antiguidade, as feiras livres constituem um importante meio de comercialização e também um espaço diversificado, no qual as pessoas se reúnem em um determinado local para realizar vendas ou trocas de produtos. Trata-se de um negócio que, ao longo de sua história, vem se transformando e que apesar da redução de seus espaços em função da expansão de outros canais de comercialização, como os supermercados e os shoppings, até hoje, as feiras desempenham um papel relevante na consolidação econômica, histórica, social e cultural das cidades, constituindo-se num ícone cultural (GOMES, SILVA, SANTOS et.al, 2013; SALES, REZENDE,SETTE, 2011).

Apesar de sua importância cultural, social e econômica, a feira representa um ambiente de mercado ainda pouco explorado no âmbito dos estudos organizacionais brasileiros. As pesquisas brasileiras voltadas para a temática feira têm abordado, por exemplo, sua tipologia, como a feira dos produtores (DIAS, SOUZA, 2014; OLIVEIRA, MISSAGIA, 2014), a feira de negócios (SIQUEIRA et al., 2014), a feira de artesanato como produto turístico (MACHADO, FILHO, 2014), feiras de negócios, destacando aspectos de satisfação dos visitantes (KUHN et al., 2014) e possibilidades de internacionalização (VEIGA et al., 2013); suas relações entre compradores e vendedores (LIMA et. al, 2012; CARVALHO et al., 2010); sua identidade e a dos feirantes (SOUZA, ALMEIDA, PIMENTEL, 2008a; SÁ, 2010; CARRIERI et al., 2008b; (SOUZA, ALMEIDA, PIMENTEL,2008b), abrangendo questões de significado atribuídas ao trabalho (SOUZA, TOLFO, 2009) e aprendizagem organizacional (SOUZA, 2001); sua institucionalização e sobrevivência (CARRIERI et al., 2007; CARRIERI et al., 2008a); e sua cultura organizacional (FERRAZ, 2011; CAVEDON, 2002).

Dentre as feiras livres brasileiras, destaca-se no Nordeste a feira central de Campina Grande no interior da Paraíba, que é considerada como sendo uma das feiras mais tradicional e relevante, no que se refere aos seguintes aspectos: abrangência comercial, relevância regional, atração de inúmeros clientes e clientes em potencial, que geram receita de frequência, no mínimo, semanal, amplitude cultural, entre outros aspectos (ARAÚJO, 2011; MIRANDA, 2009).

Por outro lado, a dignidade tem se mostrado um tema que tem ganhado espaço nos estudos organizacionais (TEIXEIRA, 2008). No entanto, no ambiente de feira livre, o tema dignidade humana não foi ainda contemplado, constituindo uma lacuna no conhecimento.

Desse modo, o objetivo geral deste estudo consiste em compreender como se estabelecem relações de dignidade entre feirantes e clientes no mercado da feira central de Campina Grande. Para o alcance do objetivo geral foram estabelecidos dois objetivos específicos: a) compreender a concepção de dignidade humana para feirantes e clientes; b) identificar a concepção de feirante e clientes dignos, na concepção de cada um.

Este artigo inova tanto ao buscar gerar conhecimento sobre o relacionamento entre feirantes e clientes, quanto ao avançar no conhecimento sobre dignidade no âmbito das organizações, buscando compreender concepções relativas ao papel de feirante e de cliente, na relação entre ambos. 


\section{DIGNIDADE HUMANA NAS ORGANIZAÇÕES}

A dignidade humana nas organizações abrange aspectos relacionados à dignidade do trabalhador (ROSS, 2013), dignidade no/do trabalho (BERG; FROST, 2005), dignidade no local de trabalho (BRODIE, 2004), levando em consideração os sentimentos e percepções do trabalhador em relação ao seu trabalho, as relações estabelecidas entre trabalhadores e entre estes e superiores hierárquicos, assim como práticas organizacionais a eles dirigidas, no contexto interno de uma determinada organização (HEPPLE, 2001; HODSON, ROSCIGNO, 2004; MATTSON; CLARK, 2011).

Alguns estudos, no entanto, abordam dignidade no/do trabalho, no local de trabalho e práticas de gestão de pessoas como trabalho decente (ver GHAI, 2003). 0 trabalho decente tem sido estudado sob diferentes facetas, dentre as quais, destacam-se: as condições de trabalho, tais como: salubridade e higiene (AUERBACH, 1988; AGASSI, 1986); segurança no trabalho (GHAI, 2003), trabalho alienante e seus reflexos tanto na vida do trabalhador quanto no trabalho (AGASSI, 1986).

Os baixos salários, riscos inerentes ao trabalho, recursos insuficientes do local de trabalho e baixa qualificação do trabalhador são aspectos que influenciam negativamente a percepção do trabalhador sobre sua própria dignidade, bem como a dignidade no/do trabalho, afetando, assim, o trabalho decente. Por outro lado, os altos salários, níveis adequados de ocupação/posto e recursos, acesso ao treinamento pessoal, adequados recursos para os seus trabalhos, e não fazer mais trabalhos do que ele possa fazer são variáveis que estão mais associadas com dignidade no trabalho (BERG, FROST, 2005).

Os trabalhos alienantes refletem negativamente tanto na vida do trabalhador quanto no trabalho. Possuem as seguintes características: causam danos mentais psicológicos e/ou psicossomáticos (temporários ou não); não oferecem oportunidade para o trabalhador aprender coisas novas; afetam a performance do trabalhador, trazendo insatisfações laborais, tais como: baixo nível de interesse, pouca criatividade e interesse do indivíduo no trabalho. Além disso, a fragmentação e repetição de tarefas é a maior característica dos trabalhos que causam efeitos negativos, aliados à perda de autonomia no trabalho e significância deste para o trabalhador (AGASSI, 1986).

Em suma, o trabalho tanto pode destruir a vida do trabalhador, caso não existam condições mínimas para o seu exercício com dignidade, quanto pode auxiliá-lo na sua emancipação, à medida que contribua para a construção de sua identidade social e coletiva.

Das consequências positivas das práticas organizacionais bem-sucedidas, o trabalho e a cidadania, bem como a redução de conflitos entre empregados e administradores são cruciais para a competitividade econômica, tendo em vista que os trabalhadores necessitam ser tratados com respeito e receber benefícios tangíveis em troca de seu maior esforço e empenho (HODSON, ROSCIGNO, 2004).

\section{A FEIRA LIVRE ENQUANTO MERCADO}

A feira livre é um mercado socialmente construído ao longo da história (ver GRANOVETTER, 1985, 2007). Apesar de terem, ao longo do tempo, seus espaços reduzidos em função da expansão de outros canais de comercialização, como os supermercados e os shoppings, desempenham até hoje um papel relevante, constituindo-se numa atividade econômica e social importante na vida de muitos trabalhadores, estimulando a economia local. (SÁ, 2010; GOMES et al., 2013; SALES, REZENDE, SETTE, 2011; ARAÚJO, 2011).

É um ambiente diversificado e movimentado, cheio de sons, cores, odores etc. Os aromas se misturam: o perfume exalado pelas frutas e flores junta-se aos odores dos peixes. Pessoas de posses, pobres, brancos, negros, turistas, letrados, todos circulam pelas feiras (FERREIRA et al., 2011; CAVEDON, 2002).

Em relação às suas peculiaridades e singularidades, a feira livre é um ambiente ímpar de comércio em função de várias características, tais como: oferta de produtos diferenciados e de qualidade; relações de amizade e confiança estabelecidas entre vendedores e fregueses, que favorecem aos feirantes conhecerem as necessidades e desejos dos seus clientes e, dessa forma, aprimorar aspectos produtivos e de venda, a fim de atender continuamente a essas necessidades; ambiente intrinsecamente lúdico, que ultrapassa o espaço de comercialização propriamente dito (SALES, REZENDE, SETTE, 2011).

Muitas cidades do interior nordestino se consolidaram e expandiram economicamente, comercializando seus produtos nas feiras livres. Destaca-se, contudo, como objeto deste trabalho, a feira de Campina Grande, na Paraíba, cuja origem está diretamente ligada ao surgimento da cidade e ao processo de urbanização do Brasil. 
Localizada nos arredores de um caminho usado desde o tempo colonial próximo à Estrada Real, Campina Grande é o tipo da cidade mercado, que se relaciona com o sertão, o brejo e a capital, bem como com outros estados da mesma região: Pernambuco, Rio Grande do Norte e Ceará (CARDOSO, MAIA, 2010).

A feira de Campina Grande continua sendo um espaço integrador, que liga o campo à cidade, pois é para as feiras que se dirigem os agricultores e criadores. 0 dia da feira é marcado por muitas conversas, compras e vendas de produtos diversificados. É o momento em que os pequenos agricultores da redondeza trazem os seus produtos para serem vendidos e se abastecem de outros gêneros. É também o momento do encontro com o cliente, o esperado e amigo cliente, além de um espaço destinado às amizades e diversas conversas, que tratam de assuntos variados, desde problemas familiares, religião, política, até dicas de receitas, remédios, entre outros (CARDOSO,MAIA, 2010, ARAUJ0, 2011).

A feira de Campina Grande é marcada pela mistura do novo com o velho, do rural com o urbano, do moderno com o tradicional. Encontram-se desde produtos manufaturados de maneira rudimentar, como lamparinas de latas reutilizadas; abano de palha para fogão; chapéus de couro e de palha, até aparelhos eletrônicos e serviços, como "disque feira" e "disque frete" (PEREIRA JUNIOR, 1977).

\section{METODOLOGIA E PROCEDIMENTOS METODOLÓGICOS}

A metodologia utilizada foi a pesquisa qualitativa sob a abordagem interpretativista (CRESWELL, 2010), no contexto da Feira Central de Campina Grande. Quanto aos procedimentos técnicos, a fim de apreender e compreender a realidade investigada, utilizaram-se: observações e entrevistas semidirigidas, de maneira face à face.

\subsection{PARTICIPANTES DO ESTUDO, FORMAS DE ACESSO, TÉCNICAS DE ANÁLISE}

Participaram deste estudo 35 sujeitos, sendo 25 feirantes e 10 clientes. Dos 25 feirantes entrevistados, 16 são do sexo masculino e 09 do sexo feminino, de faixa etária a partir de 26 até 75 anos. 0 nível de escolaridade varia desde o ensino fundamental incompleto até o ensino superior. Os tipos de produtos comercializados são variados e vão desde gêneros alimentícios até utensílios, redes, roupas, ferragens, sandálias, DVD, flores, mercadinho, bar e lanchonete, artigos de couro e cereais, grãos e estivas. Quanto ao tempo que trabalham na feira, este variou de 04 até 60 anos.

Em relação aos 10 (dez) clientes entrevistados: 07 (sete) são do gênero feminino e 03 (três) do gênero masculino. Todos os entrevistados são casados, tem filhos, estão inseridos no mercado formal de trabalho, tendo de 29 a 70 anos. Foram escolhidos mediante os critérios de acessibilidade e saturação, ou seja, as entrevistas foram concluídas à medida que as respostas passaram a se repetir.

Utilizou-se um roteiro semi-estruturado de entrevista, no qual constavam as seguintes perguntas: o que era dignidade, o que era um feirante digno e também um cliente digno. Nas observações, que foram registradas em diário de campo, atentou-se, principalmente, para aspectos relacionados à organização da feira, em termos de infra estrutura, formas dos feirantes arrumarem, exporem, divulgarem e venderem seus produtos, maneiras como os feirantes interagem com os clientes e demais feirantes, reações dos entrevistados frente às perguntas realizadas. Com estas perguntas e observações, construiu-se o significado de dignidade.

Os feirantes foram convidados a participar da pesquisa seguindo o critério de um feirante por tipo de artigo comercializado. Para realizar as entrevistas, a pesquisadora dirigia-se à barraca, perguntava quem era a pessoa responsável e em seguida convidava-a para participar da pesquisa e esclarecia acerca dos objetivos do estudo. A receptividade à pesquisa foi um ponto de destaque.

Os feirantes investigados trabalham com outros membros da família e, apenas um dos entrevistados contava com o serviço de um empregado. A inserção deles no comércio da feira, ocorreu principalmente em função de terem nascido na feira, aprendendo a profissão com seus familiares, tendo os pais um papel central nesta socialização, seguido dos tios e esposos, especificamente para as mulheres feirantes.

No caso dos homens, notou-se que a maioria deles trabalhava na agricultura, antes de ser feirante, optando por este tipo de comércio em virtude de ser mais rentável. Em menor escala, alguns deles perderam o emprego ou tiveram dificuldade para inserir-se no mercado de trabalho formal e passaram a trabalhar por conta própria, criando seu próprio negócio. 
Já a maioria das mulheres, vieram trabalhar na feira a fim de acompanhar seus esposos, ajudando-os no comércio e também para obterem rendimentos, que as possibilitassem criar e educar seus filhos

Os clientes foram abordados tanto na feira livre quanto em outros ambientes externos a este comércio, como por exemplo suas residências e locais de trabalho. 0 critério usado para escolha destes entrevistados consistiu no fato de todos eles frequentarem a feira de Campina Grande com regularidade, ou seja, pelo menos uma vez por semana. À medida em que as respostas dos clientes passaram a repetirem-se, encerraram-se as entrevistas..

$\mathrm{Na}$ interação feirante-cliente, observou-se que os feirantes procuram tratar os clientes com bastante amizade e acolhimento, como se eles, os clientes, fossem seus amigos e/ou pessoas da família, inclusive trocando confidências e "mimos". Alguns feirantes revelaram que já foram auxiliados por seus clientes, mediante conselhos, consultas, medicamentos e até mesmo conseguindo escola e/ou trabalho para seus filhos. A maioria dos clientes revelou que gosta de ir a feira não só por terem acesso a produtos de qualidade, como também devido o calor humano.

As entrevistas foram transcritas na íntegra e, em seguida, analisadas conforme técnica de análise de conteúdo. Inicialmente, as falas dos entrevistados foram analisadas separadamente, levando em consideração o grupo de feirantes e o grupo de clientes. Como algumas falas não vieram na ordem em que as perguntas foram feitas durante a entrevista, houve a condensação destas, seguindo, para efeito de análise, os objetivos pré-estabelecidos neste estudo.

Além disso, após ler várias vezes as entrevistas de cada grupo (clientes e feirantes) observaram-se semelhanças nas falas dos entrevistados, o que possibilitou as autoras deste artigo, respaldadas na literatura investigada, no teor do conteúdo coletado e também nos objetivos pré-estabelecidos, agrupar tanto as falas dos feirantes (F) quanto às falas dos clientes (C), mediante os seguintes aspectos: Dignidade humana e, Dignidade associada ao papel específico do stakeholder.

Sendo assim, os resultados obtidos são apresentados e discutidos simultaneamente, levando-se em consideração, basicamente, dois itens: Concepção de Dignidade humana para feirantes e clientes e Dignidade associada a papeis desempenhados pelos stakeholders. Sendo este último, subdividido em dignidade relativa ao feirante digno e dignidade relativa ao cliente digno.

\section{RESULTADOS E DISCUSSÕES}

\subsection{CONCEPÇÃO DE DIGNIDADE HUMANA PARA FEIRANTES E CIENTES}

A Dignidade Humana para os feirantes e clientes entrevistados mostrou-se relacionada a valores morais, benevolência, educação, sentimentos e distinção. 0 respeito ao próximo e à vida, honestidade, lealdade, sinceridade e honra foram os valores morais mais frequentemente apresentados, conforme mencionaram, por exemplo: "A dignidade é respeitar o próximo [...] não pegar nada alheio, procurar levar sua vida dentro das coisas possíveis, desde que não engane a ninguém " (F24). "uma mercadoria no peso, eles pesam certo, nunca procuram enganar o cliente" (C8). Benevolência com relação a si próprio e para com os demais, foi outro significado atribuído:"viver sempre bem com você mesmo.... passar sempre o melhor para as pessoas" (F7).

Educação emergiu nas falas dos entrevistados como sendo uma forma de lidar com o outro ("Cuidar bem do cliente "- F1). Sentimentos, no que se refere a trabalhar em algo e com algo que realmente goste e faça feliz ("Ter felicidade, ter amor e ter carinho [pelo que faz]- F6). Já, distinção, diz respeito a algo diferenciado, conforme ilustra a fala: "uma coisa ali diferente em você "(F1); "digno daquilo que faço" (F25).

A diversidade de sentidos atribuídos à dignidade humana é confirmada na literatura, mediante os estudos de Sarlet (2011) ao fazer um resgate histórico sobre os significados atribuídos a dignidade humana, desde a antiguidade clássica até os dias atuais. Nesse estudo, observou que o conceito é abrangente, complexo, diversificado, multifacetado, de ampla aplicabilidade e que vem modificando-se ao longo da história,

Entre os significados atribuídos a dignidade humana, destaca-se a concepção do filósofo Kant (2005), no que se refere ao homem ser dotado de dignidade devido a capacidade racional de definir normas e usá-las conscientemente para guiar suas próprias ações, de maneira, livre e autônoma. Para ele, a dignidade é o que não tem preço e, a vontade de ser livre está submetido as leis morais. A faculdade de pensar e autonomia para agir torna o homem não um meio, mas, um fim em si mesmo.

Ainda segundo Kant (2005), nas relações interpessoais, o respeito deve ser dado a todas as pessoas, de maneira geral, e não apenas a um indivíduo em detrimento do outro. Trata-se de um imperativo 
categórico, o respeito, e não depende de nossas inclinações, é um assunto racional e convencional. As práticas sociais do respeito são vitalmente importantes e devem ser dada atenção a algumas formas simbólicas apropriadas: formas de contato, contato corporal, contato mediante os olhos, linguagem não agressiva, atribuir autonomia, fundamentação de "opiniões", comportamento, entre outros.

Sendo assim, o sentido de valores morais e de benevolência, apresentado pelos entrevistados, remete a concepção de Kant (2005) ao tratar do respeito interpessoal, no que diz respeito as normas racionais de conduta, por exemplo: não pegar nada alheio; não enganar as pessoas e tratar as pessoas da melhor maneira possível, passando o melhor de si.

A educação, no sentido de cuidar bem do cliente, a luz de Kant (2005) pode ser visto como uma forma respeitosa de tratar o outro.

\subsection{DIGNIDADE RELATIVA AO FEIRANTE DIGNO}

Feirante digno para os feirantes e clientes entrevistados associa-se a valores morais; conhecimento acerca do produto que comercializa e também da profissão que exerce; esforço, no dia a dia do comércio, bem como receber remuneração adequada, pelo trabalho realizado.

0 respeito, a honestidade e o dever foram os valores morais que os entrevistados mais revelaram em suas falas, conforme ilustram as seguintes falas: "... a partir do momento que a pessoa venha comprar aqui em mim, se eu vier faltar com respeito com ele não só moral ou qualquer outra forma, eu tou excluindo ele do meu próprio trabalho" (F24). “... quando eu respeito o cliente, eu acho que o cliente me respeita e acho que tou sendo digno daquilo do meu trabalho (F25). "respeito em oferecer produtos de qualidade"(C3)."sem desrespeitar o vizinho dele que também é outro feirante" (C4).

Um feirante digno seria uma pessoa que tem amor ao seu negócio, que tem respeito ao seu cliente, respeito esse em atendimento, em produtos de qualidades, preços justos e que tem interesse em atender bem, é um feirante que atenda o cliente de modo igualitário, independente do cliente, independente da hora, independente do dia e que tenha um preço tabelado para todos eles, esse é um feirante digno, é um feirante honesto (C3)

A honestidade, enquanto valor moral, é exemplificada nas seguintes falas:"coloca a margem [de lucro] honesta, para que ele não só ganhe como o consumidor também" (C6); "passa o troco do cliente com honestidade, nunca procura enganar o cliente, se por acaso por descuido a gente der um dinheiro a mais eles devolvem"(C8.). "Ter uma tabela de preço normal pra todos [...] porque tem muitos que quando vê que você tem um dinheirinho a mais, ele explora, isso aí não é ser digno" ( F14);

Não abusar da boa vontade dos clientes e trabalhar com seriedade [ou seja] você põe a mercadoria, você coloca numa balança e você cobra aquilo que é legitimo, por exemplo, eu peso um quilo de mercadoria, eu não vou colocar 900 gramas porque pra mim isso não é digno, então 1 quilo pra mim é 1 quilo, eu cobro o que é correto"(F20); "Ele sempre procura vender a mercadoria boa (C1);

"venda pelo preço correto" (C6, C3); "procura sempre manter o ambiente limpo e bem arrumado" (C1).

Já o dever emergiu nas falas, conforme as ilustrações: "feirante digno é aquele que compra e paga" (F2,F3); "aquele que cumpre os seus deveres como um cidadão" (F2).

Mais uma vez, o significado de feirante digno, atrelado a valores morais (respeito, honestidade e dever), revelado nas falas dos entrevistados, remete ao pensamento de Kant (2005) ao se referir à liberdade e autonomia que o ser humano possui de criar normas e utilizá-las como critério para conduzir seu comportamento e também ao respeito, como princípio básico das relações interpessoais, conforme abordado no item, que se trata da dignidade humana para feirantes e clientes.

Conhecimento abrange os aspectos: conhecer a origem da mercadoria ("comprar direto da fonte, não comprar a repassadores, que às vezes a gente não sabe o histórico dessa mercadoria"- F9) e características do produto:" todo feirante é mais que um comerciante, ele é um especialista e ás vezes ele próprio plantou ou ele próprio fabricou aqueles queijos, ou pelo menos, conhece diretamente as pessoas com as quais ele tem contatos comerciais"- C9); ter conhecimento do que faz ("segurança de propriedade pra fazer seu trabalho"F13). 
Para Sales, Rezende, Sette (2011), a feira livre é um ambiente singular de comércio em função de várias características, tais como: a) oferta de produtos diferenciados e de qualidade; b) relações de amizade e confiança estabelecidas entre vendedores e clientes, que favorecem aos feirantes conhecerem as necessidades e desejos dos seus clientes e, dessa forma, aprimorar aspectos produtivos e de venda, a fim de atender continuamente a essas necessidades. Como se pode notar pelos relatos dos entrevistados, o feirante digno é aquele que comercializa produtos de boa qualidade e de procedência segura, tendo conhecimento desde a origem do produto, destacando quem, como e onde o produto foi produzido, até as características básicas do produto que comercializa, em termos de qualidade. Além disso, o feirante digno precisa conhecer as necessidades e expectativas dos seus clientes, a fim de melhor atendê-los e também "domínio" da profissão que exerce, no que se refere a saber o que está fazendo e "fazer" de maneira segura.

Esforço relaciona-se a luta diária do trabalhador, que é marcada pelo suor do seu rosto conforme ilustra a fala: " É você sair de 5 horas da manhã de casa e trabalhar com suas experiências, com o que você sabe e trazer o pão de cada dia para as crianças e sua família, acho que isso é o máximo de dignidade que você pode imaginar" (F5). "É com o suor do seu rosto, se ele é honesto, trabalhador"(F7).

Receber remuneração adequada as suas necessidades, no que se refere: “... a ter aquilo que é necessário para a sobrevivência e para criar a família" (F16); "tem que ter um salário digno para a pessoa cumprir com os seus deveres em casa." ( C5).

Sá (2010) considera que a feira livre, apesar de perdurar desde a antiguidade e ser uma atividade econômica e social relevante à vida de muitos brasileiros, em especial aos nordestinos, hoje está ligada à dinâmica do capitalismo contemporâneo, sendo constituída pelas instituições chaves da modernidade, estado e mercado. Diz ainda que a feira não se mostra capaz de gerar empregos para parte significativa da população e, ao mesmo tempo, se desenvolve de modo relativamente distinto, a depender da condição geopolítica da região.No interior do Nordeste,por exemplo, a feira é um espaço onde os trabalhadores nordestinos lutam por subsistência ou pelo sonho de uma vida melhor (SÁ, 2010)

Como se pode notar pelos relatos dos entrevistados, a luta diária do feirante nordestino para obter o pão de cada dia, bem como para receber remuneração adequada as suas necessidades de sobrevivência é realçado por Sá (2010) ao referir-se a necessidade de que o comércio das feiras livres precisa ser administrado, de maneira eficaz a fim de gerar novos empregos e maior rentabilidade.

Apenas nas falas dos feirantes, emergiram que feirante digno é aquele que coloca o foco no seu trabalho: " $E$ o que trabalha sem olhar o vizinho [outro feirante], sem olhar o que os outros fazem ... foca no seu trabalho não no do próximo"(F1) e também ganha pelo que trabalha: "trabalha e ganha o que merece pelo valor do trabalho dele, porque hoje ninguém trabalha mas ninguém recebe pelo que trabalha"(F23). Por outro lado, apenas nas falas dos clientes emergiram que o feirante digno deve apresentar assiduidade, pontualidade e vender produtos de qualidade.

\subsection{DIGNIDADE RELATIVA AO CLIENTE DIGNO}

Cliente digno, para os feirantes e clientes entrevistados, associa-se a valores morais e também a comprar e pagar com seus próprios recursos.

A fidelidade e a confiança foram os valores morais que mais emergiram nas falas dos entrevistados. Ser fielestá associado a só comprar a um determinado feirante, mesmo que ele não dispunha da mercadoria no momento ("... Não, se você não tiver [ a mercadoria] eu não levo, eu venho amanhã e pego com você amanhã" - F15) e também por voltar sempre à barraca("É aquele cliente que vem sempre ... mesmo que ele não compre, ou que ele não tenha condições de comprar assim no momento, mas ele torna-se assim uma pessoa digna só por ele não comprar, mas por ele voltar- F7).

Observou-se que o fato do cliente voltar à barraca relaciona-se ao atendimento e à qualidade da mercadoria (“... o preço é igual, mas a mercadoria é melhor, o atendimento é melhor"- F14). Além disso, "voltar à barraca" transmite dignidade ao feirante, conforme a fala: "Um cliente digno é aquele que volta outras vez e isso pra nós tanto é digno, como nos transmite dignidade"(F2).

Notou-se também que, a depender da relação com o cliente, o feirante torna-se digno como sendo uma forma de retribuição: "do jeito que vocês [os clientes] são dignos, eu também sou a ele, eu retribuo da mesma forma: muitas vezes a mercadoria falta e eu guardo... chega cliente de fora, nunca me compra "e aquele?" aquele já está vendido, porque é pra aqueles clientes, que é digno de me atender, por quê? porque eles são fiéis a mim "(F13). 
Para Mattson e Clark (2011), a dignidade deve ser percebida como um valor do indivíduo, que se baseia no bem estar, criado na relação com os outros, podendo ser afetada pelo mundo físico e pela estrutura de valores. Esta concepção de dignidade abrange tanto os aspectos da individualidade humana quanto os aspectos comunitários da cultura, além de propiciarem implicações em algumas práticas políticas. Na mesma direção de Mattson e Clark (2011), o Week (2013) considera que a dignidade humana faz parte da natureza ou essência humana e também é algo aprendido, mediante as relações interpessoais e, também construída a partir da interação social estabelecida entre indivíduos e indivíduos e organizações.

Como pode ser notado, mediante as falas dos entrevistados, a dignidade é construída a partir da interação estabelecida entre feirantes e clientes. A fidelidade do cliente, demonstrada pelas ações de comprar o produto, apenas a um determinado feirante e também voltar ou visitar a sua barraca, de maneira costumeira são comportamentos dos clientes que favorecessem aos feirantes sentirem-se dignos. 0 sentirse digno, por sua vez, estimula aos feirantes agirem em direção aos clientes com comportamentos de retribuição, tais como guardar o produto para o "seu" cliente, mesmo que outro cliente deseje, já que ele é fiel.

Já a confiança, enquanto valor moral apareceu na relação entre cliente e feirante, conforme a fala: “Em qualquer situação, se ele vem comprar a mim, e por exemplo se ele tá sem dinheiro e precisa levar alguma coisa, se eu vendi é porque eu confiei nele, se ele vier a deixar de me pagar, aí é uma baita de uma covardia, não só ele como eu ou qualquer outra pessoa, faltou com compromisso" (F24).

Ao buscar construir um conceito de dignidade organizacional, Teixeira (2008) observou, mediante os diversos estudos realizados, que reciprocidade implica confiança e que a consistência de comportamentos é uma das condições que promovem a confiança. "Confiança é um atributo coletivo, aplicado nas relações entre pessoas, capaz de reduzir a complexidade e de reduzir os custos de transação” (TEIXEIRA, 2008, p. 84).

Como pode ser notado, mediante as falas dos feirantes e dos clientes, se o feirante vende ao cliente, que está sem o dinheiro no momento da compra, fez isso porque confiou nele. Caso o cliente não pague, faltou com o seu compromisso, inibindo a confiança anteriormente presente na relação.

Comprar e pagar, no prazo combinado, mediante seus esforços e recursos são comportamentos dos clientes, que apareceram nas falas dos entrevistados como sendo significado de cliente digno, conforme ilustram as falas: "Aquele que compra e mesmo sendo fiado ele volta pra pagar"( F10). “... sem tirar de outra pessoa pra tá comprando ali"(C6).Esse resultado, entendido como um comportamento do cliente que inspira confiança ao feirante, remete aos estudos de Teixeira (2008) ao abordar o valor da confiança, conforme discutido no parágrafo anterior.

Já, o comportamento de não maltratar o comerciante, como significado de cliente digno é ilustrado: "Se achar que o preço está caro, não precisa comprar, é só não soltar piada, pilera, se reporta a outra banca, mas, não agride o feirante falando do seu produto, da qualidade, do preço, da balança, coisas do tipo"(C2). Maltratar, pisar, desconfiar e soltar piadas apareceram nas falas dos feirantes como sendo formas do cliente expressar indignidade,conforme ilustram as falas: “... que venha com um gesto, um jeito de maltratar ou querer pisar [o feirante])"(F5); "Tem umas pessoas que machuca muito a gente, desconfia"(F14).

Apenas as falas dos clientes revelaram que cliente digno relaciona-se ao fato do cliente compreender as especificidades da feira e agir conforme o local ("... o consumidor da feira sabe, por exemplo, que é possível pedir uma diminuição no preço, sabendo que os vendedores tem essa disponibilidade, ao contrário do super mercado que o preço tá lá e você compra e tchau e acabou, ou não compra."(C9).

Sales, Rezende e Sette (2011) ao referirem-se as peculiaridades do comércio da feira, destacam que a feira é um ambiente intrinsecamente lúdico, favorável a construção de amizade entre feirantes e clientes, oportunizando a ambos, a troca de confidências. Dizem também que cabe aos feirantes oferecerem aos clientes, produtos "novos", de boa qualidade e de procedência segura, como uma forma de demonstrar que sabe o que está fazendo e também para atender as necessidades dos clientes, que na maioria das vezes passam a ser denominados de amigos. Logo, conforme notado na fala dos entrevistados, os comportamentos de maltratar o feirante devem ser evitados a fim de evitar constrangimentos, afetando a criação e desenvolvimento de amizades e encontros agradáveis entre feirantes e clientes, o que é característico deste tipo de comércio.

Apesar de não se ter investigado diretamente os motivos que estão afastando os clientes da feira, de maneira espontânea, as falas dos feirantes revelaram que esse fato ocorre em virtude da: falta de dignidade, falta de compreensão, falta de respeito e também devido ao feirante não ter compromisso com o tipo de material que trabalha. Estes resultados, apesar de não terem sido detectados na literatura 
investigada, possibilitam aos feirantes repensarem suas práticas de gestão e respectivas consequências, em termos de crescimento e desenvolvimento organizacional. Ademais, contribuem com os estudos de Teixeira et al. (2014), na medida em que consideram as vozes dos stakeholders no processo de construção de práticas organizacionais dignas.

\subsection{RELAÇÕES DE DIGNIDADE ENTRE FEIRANTES E CLIENTES}

No que se refere à maneira como os feirantes se relacionam com os clientes, notou-se que a maioria dos entrevistados disse ter relacionamento "bom" ou "maravilhoso" com os clientes. Ou seja, eles procuram ter "jogo de cintura", fazendo de conta, às vezes, que não veem ou não ouvem para superarem os conflitos oriundos da relação com os clientes; buscam transformar relacionamentos tensos e ruins em relacionamentos amigáveis, a fim de que os clientes voltem a comprar em suas barracas, fidelizem-se e tragam rentabilidade; procuram "livrar-se" dos clientes inconvenientes, o que eles denominam de "mostrados".Veja-se como as falas a seguir ilustram tal análise:

[...] você tem que em muitas coisas: ver e fazer que num vê, escutar e fazer que num escuta. Muitas coisas tem que entrar num ouvido e sair no outro [...] coisas boas agente guarda [...]. Essas coisas ruins a gente joga no mato, não fica conosco [...] (F12).

[...] as vezes chega um cliente brabo e sai alegre, né? A gente faz aquela [...], ajeita ele né? Faz aquela amizade boa, então se tornamos grandes amigos"(F4). "Ah eu tenho que me relacionar muito bem com eles, tratar ele melhor do que o pessoal em casa, porque eles que me mantém(F8).

[...] Tem freguês que chega com mal estar e atrapalha até os outros. Muitas vez eu boto até na frente de todo mundo, porque todo mundo se acha assim incomodado com aquela pessoa. Boto na frente para ele ir embora. Não é porque ele é bonito não, Gente mostrada deve sair primeiro que todo mundo(F12).

Apenas um entrevistado disse que o relacionamento com o cliente era tenso e difícil, alegando que a principal dificuldade consiste na desvalorização ou depreciação da mercadoria pelo cliente, apesar da mercadoria ser de boa qualidade:

Já é meio difícil, meio complicado, porque assim, às vezes, a gente tem que atender de uma forma que possa ser bom pra mim e pra ele, mas ás vezes o cliente são muito exigentes e falta paciência pra ele, muita [...]. Por exemplo, fala que a carne não está boa, estando boa, entendeu? e exige, é, fica bem complicado, mas assim, a gente já tem uma experiência, a gente sabe que tem que ter paciência mesmo e tentar levar na boa (F13).

Os relacionamentos com os clientes não são quaisquer relacionamentos, são "aqueles" relacionamentos que inspiram confiança, lealdade, amizade. Os clientes devem ser "sempre" bem atendidos, independente do que eles dizem e fazem. Aliás, um dos diferenciais da feira livre está na qualidade dos produtos, variedade e bom atendimento. Nas feiras, os clientes são tratados como pessoas da família e não como simples clientes, conforme ocorrem nos grandes supermercados e shoppings. Estes achados reforçam os pensamentos de Samara e Morsch (2005), ao declararem que a compreensão das necessidades e desejos dos clientes, aliados à busca de estratégias que os tornem continuamente satisfeitos, consiste num diferencial competitivo, que agrega valor ao negócio e também favorece oportunidades de desenvolvimento e expansão organizacional.

Observou-se também, mediante as falas dos feirantes, que eles não devem tratar o cliente mau, o que para eles significa enganar ou explorar o cliente com mercadorias sem qualidade ou com preços excessivos. 
Informaram que devem tratar bem o cliente para evitar propaganda negativa e mesmo sendo maltratados pelos clientes, devem tratá-los bem e, se necessário, ficar calados para evitar embate ou para não se igualar a eles, como demonstram as seguintes respostas:

Enganar o cliente. Dizer que o produto é novo sem ser. Dizer que vai ter uma mercadoria em tal dia e não ter. Ou dizer que vai guardar a mercadoria para o freguês e não guardar (F12).

Primeiro é exploração. Segundo, é tratar com indiferença, né? [Ex.] Porque eu vejo comerciante aqui, que ás vezes você vai comprar uma feira grande, é tratado de maneira simpática, carinhosa, mas se você vem comprar uma cebola, duas cebolas, é tratado com indiferença e de forma ignorante (F14).

A mercadoria ruim que a gente tem não coloca pra vender. [Ex] no caso da goma mesmo, ela tem muito problema, quando ela vem sem lavar ela fica azeda. Aí o cliente faz a tapioca com ela azeda e não presta. Ai [...] a gente tem que encostar, não pode vacilar, se não perde o cliente (F15).

[...] não maltratar, atender bem, sabe? assim a mercadoria, se ele der um preço, se ele dizer que a mercadoria alí é mais barato a gente fica calado, né? Porque num vai voltar novamente, né? Pra comprar, porque se a gente disser "lá fora é mais caro" a gente vai se aborrecer e o cliente também, né? (F11).

[...] se você trata um cliente mal, ele vai propagar pra 10 pessoas no mínimo e se você tratar ele bem, ele vai propagar só pra duas, então você viu a diferença na porcentagem, então é isso (F9).

Os resultados encontrados reforçam a literatura de marketing, no que se refere à necessidade contínua das organizações em tratar bem os clientes. Tratar bem o cliente é uma ação que agrega valor ao negócio, tornando-se fonte de vantagem competitiva. Logo, não só os profissionais da área de marketing, como também os demais profissionais que fazem parte da organização, devem estar atentos e procurar "cuidar" desta relação, empresa-cliente. Clientes satisfeitos retornam às empresas, compram seus produtos e/ou serviços, fidelizam-se e, por fim, propagam no mercado suas qualidades positivas, despertando nas demais pessoas a vontade de conhecê-la, experimentá-la e, possivelmente, tornassem clientes. Em contrapartida, clientes insatisfeitos divulgam negativamente a empresa, podendo ferir sua imagem e reputação no mercado (KARSAKLIAN, 2004;SAMARA e MORSCH, 2005).

Os autores mencionados (op.cit.) alertam que é mais "fácil" criar junto aos clientes, uma relação de amizade e confiança do que restabelecer este tipo de relacionamento. Dizem, ainda, que o processo de reconstrução da confiança requer das empresas investimentos elevados, que envolvem todos os setores da empresa, sejam de marketing, de gestão de pessoas, financeiro, planejamento, entre outros.

\subsubsection{PAPEL DO GOVERNO NA CONSTRUÇÃO DE AMBIENTE DIGNO}

Apesar de não se ter investigado a relação entre dignidade e governo, de maneira espontânea, o "tom" das falas dos feirantes revelaram uma "certa" crítica e/ou insatisfação com o papel do governo e demais órgãos públicos na feira de Campina Grande, no que se refere a falta de estrutura, a falta de segurança, a falta de apoio ao comércio da feira, conforme ilustram as falas: "ter respeito até pelos órgãos públicos que muitas vezes falta na feira central" (F9); "ter respeito na própria estrutura, na segurança, que muitas vezes não temos o apoio do governo" (F9).

Corroborando com estas críticas, ao relatarem aspectos que não gostam na feira, os clientes mencionaram questões, referentes a higiene, ao acesso em período de chuva e também a própria organização do espaço, em termos de locomoção, dizendo: "... quando tá chovendo, as lamas [atrapalham a movimentação] Essas carroças, visse? Esses carroceiros batendo nas canelas da gente é meio ruim [para andar na feira](C4).Uma outra fala ilustra:

Tem partes da feira central, que deveriam estar mais urbanizadas e mais salubres, tem partes da feira que eu não vou de jeito nenhum porque eu acho que é insalubre, eu acho que é sujo, o chão, algumas partes é sujo, sobre tudo ás partes de frango, galinhas, aves, eu não compro na feira de jeito nenhum, porque é uma parte da feira que não me agrada visualmente e nem o odor" (C2). 
Para Ghai (2003), o trabalho decente é abrangente e corresponde as atividades laborais da economia formal e informal. Diz respeito, entre outros aspectos, as condições saudáveis de trabalho.

Ainda em relação às condições negativas do ambiente de trabalho, Berg e Frost (2005) realizaram um estudo a fim de investigar como os trabalhadores, que têm sido tradicionalmente marginalizados na economia americana, almejam obter prosperidade e dignidade no trabalho. Os autores (op.cit) acreditam que dignidade no trabalho não é apenas relevante para o trabalhador, mas também, para a organização e para a sociedade, tendo em vista que trabalhar com dignidade é fundamental para plena realização na vida, já que a dignidade no trabalho favorece a construção de cidadãos ativos em suas comunidades. (BERG, FROST, 2005).

Como pode ser observado, os feirantes e clientes revelaram insatisfações frente ao apoio recebido do governo, destacando a falta de segurança, bem como a precariedade do espaço físico em termos de higiene, acessibilidade e salubridade, no qual funciona a feira livre de Campina Grande. Estas insatisfações podem ser vistas como aspectos negativos do ambiente de trabalho, que interferem no trabalho decente, conforme apontaram Ghai (2003) e Berg, Frost (2005).

Logo, mediante as falas dos entrevistados, nota-se o relevante papel do Governo na construção de relações de dignidade. No ambiente da feira, não basta as relações entre cliente e feirante serem dignas, é necessário que as condições básicas de infraestrutura sejam dignas e esse é um papel do governo.

\section{CONSIDERAÇÕES FINAIS}

O presente estudo, que teve como objetivo geral compreender a concepção dos feirantes e clientes da feira livre de Campina Grande sobre dignidade humana, e dignidade relativa ao cliente e ao feirante nas relações entre ambos, na perspectiva de cada um, foi alcançado com os estudos realizados e procedimentos metodológicos adotados.

Os significados de feirante digno e de cliente digno pressupõem os significados de dignidade humana, passando a incorporar além deste, o significado de dignidade relativa ao papel específico do stakeholder.

Apesar de ocuparem posições distintas em relação à organização informal, no caso a feira livre, as falas dos feirantes e as falas dos clientes, que fazem parte, respectivamente, do ambiente interno e externo à feira, apresentaram conteúdos semelhantes em termos de categorias elaboradas tanto para conceberem dignidade humana quanto para conceberem dignidade reativa ao papel específico do stakeholder, preservando, obviamente, a maneira como cada entrevistado percebe os assuntos investigados. Mas, porque tanta semelhança nas categorias de análise elaboradas?

Refletindo sobre este instigante questionamento, supõe-se que isto ocorreu devido ao fato de os entrevistados pertencerem ao mesmo universo histórico, sócio e cultural, compartilhando da mesma cultura organizacional que, por sua vez, está ligada à cultura nacional.

Ao analisar a relação entre os dois stakeholders, os feirantes e os clientes, notou-se que não basta que entre ambos exista uma interação digna. Além disso, é necessário que a relação de ambos para com o governo também seja digna, o que não foi evidenciado neste estudo. Logo, o governo tem um papel preponderante na construção de um ambiente físico digno na feira.

Espera-se que o presente estudo tenha contribuído para uma melhor compreensão da dignidade na relação entre stakeholders, no caso os feirantes e os clientes, na medida em que mostra o que é um feirante digno e um cliente digno. Além disso, que tenha contribuído com a expansão dos estudos sobre dignidade humana e organizacional, tendo em vista que explorou um tipo de organização informal pouco explorada nos estudos organizacionais, que é a feira livre, apesar de tratar-se de um ícone cultural.

Logo, continuar investigando a relação entre feirantes e demais stakeholders: administradores da feira, outros feirantes, governo, estado, comunidade etc, possibilita repensar e melhorar as práticas organizacionais.

Sua principal limitação se refere ao fato de terem sido observadas apenas as visões dos feirantes e dos clientes. Futuras pesquisas poderão ampliar o olhar sobre o fenômeno investigado, estudando a relação dos feirantes com outros stakehoders, a exemplo de outros feirantes, fornecedores e administradores da feira. 


\section{REFERÊNCIAS}

[1] Agassi, J. B. Dignity in the Workplace Can Work Be Dealienated ? Journal of Business Ethics, v. 5, p. 271-284, 1986.

[2] Araújo, B. F. B. A Construção dos Significados de Dignidade no âmbito da relação entre Empresas e Comunidade. In: XXXVII ENANPAD. Rio de Janeiro, 2013.

[3] Araújo, G. A. F. Continuidade e descontinuidade no contexto da globalização: um estudo de feiras em Portugal e no Brasil (1986-2006). Tese de Dout. em História, Especialidade em Idade Contemporânea (UMINHO) e História Social (UFBA). Regime de Co-tutela, Univ. do Minho, 2011.

[4] Auerbach, J. Organized Labor: Toward A New Dignity in the Workplace. Journal of Career Development, v. 15, n.01, 1988.

[5] Berg, P.; Frost, A. Dignity at Work for Low Wage, Low Skill Service Workers. Industrial Relations, v. 60, n. 04, 2005.

[6] Brodie, D. Protecting Dignity in the Workplace: The Vitality of Mutual Trust and Confidence. Industrial Law Journal, v. 33, p. 349-354, 2004.

[7] Cardoso, C. A. A.; Maia, D. S. A feira de Campina Grande: Onde se encontra o moderno e o tradicional. In: Anais XVI Encontro Nacional dos Geógrafos-ENG, Porto Alegre, 2010.

[8] Carrieri, A. P.; Saraiva, L. A. S.; Lima, G. C. O. L.; Maranhão, C. M. S. A. Estratégias Subversivas de Sobrevivência na "Feira Hippie" de Belo Horizonte. Revista Eletrônica de Gestão Organizacional, v. 6, p. 174-192, 2008a.

[9] Carrieri, A. P.; Saraiva, L. A. S.; Pimentel, T. D. O Processo de Institucionalização da Feira Hippie de Belo Horizonte. In: Enanpad, Belo Horizonte,2007.

[10] Carrieri, A. P.; Souza, M. M. P.; Almeida, G. O. Feirante ou barraqueiro? Identidades e estratégias na Feira do Jubileu. Belo Horizonte: Revista Economia \& Gestão da PUC Minas, 2008b.

[11] Carvalho, V. D.; Borges, L. O.; Rêgo, D. P. Interacionismo Simbólico: Origens, Pressupostos e Contribuições aos Estudos em Psicologia Social. Rev. Psicologia, Ciência e Profissão. v. 30, n. 1, p. 146-162, 2010

[12] Cavedon, N. "Pode chegar,freguês": A cultura organizacional do mercado público de Porto Alegre. In: Enanpad, Porto Alegre, 2002.

[13] Creswell, J. W. Projeto de Pesquisa: Mét. Qual., Quantitativo e Misto. P.A: Artmed, 2010

[14] Dias, T. F.; Souza, W. J. Gestão social e economica solidária: o caso da Associação dos Produtores e produtoras Rurais da Feira Agroecológica de Mossoró- Aprofam, Mossoró: Teoria e Prática em Administração, v. 4, p. 261-294, 2014.

[15] Ferraz, D. L. DA S. Processos decisórios e aspectos simbólicos: um estudo das culturas organizacionais da feira do livro de Porto Alegre. Organizações \& Sociedade, v. 18, p. 77-98, 2011.

[16] Ferreira, C. M. A.; Wanderley, D. M. A.; Ferreira, D. J. L.; Maia, H. J. L.; Medeiros, M. C. S.; LIMA, V. L. A. Percepção dos Impactos Ambientais na feira central de Campina Grande-Pb. Revista Educação Agrícola Superior, v. 26, n. 1, p. 3-6, 2011.

[17] Ghai, D. Decent Work: Concept and indicators. Internat. Labour Rev. v. 142, n.02, p.113-145, 2003.

[18] Gomes, A. F.; Silva, J. S. F.; Santos, A. A.; Santana, W. G. P. S.; Santos, J. A. G. S. Perfil Socioeconômico de Mulheres Feirantes : um estudo no interior baiano. In: IV Encontro de Administração Política, Vitória da Conquista, p. 1-16, 2013.

[19] Granovetter, M. Ação econômica e estrutura social: O problema da imersão. Fórum- Sociologia Econômica. RAE-eletrônica, v. 6, n. 1, Art. 9, jan/jun. 2007, ISSN 1676-5648.

[20] Granovetter, M. Economic Action and Social Structure: The Problem of Embeddedness. American Journal of Sociology, v. 91, Issue 3, p. 481-510, nov., 1985

[21] Hepple, B. Equality and empowerment for decent work. Internat. Labour Rev, v. 140, n. 1, 2001.

[22] Hodson, R.; Roscigno, V. J. Organizational success and worker dignity: complementary or contradictory? The American Journal of Sociology, v. 110, n.3, p. 672-708, 2004.

[23] Jacobson, N. A taxonomy of dignity: a grounded theory study. BMC International Health and Human Rights. v. 9, n. 3, p. 1-14, 2009.

[24] Jacobson, N. Dignity and health: A review. Social Science \& Medicine, v. 64, p. 292-302, 2007.

[25] Kant, I. Fundamentação da Metafísica dos Costumes e outros escritos. SP: Martins Claret, 2005

[26] Karsaklian, E. Comportamento do Consumidor. SP: Atlas, 2004

[27] Kuhn, I. N.; Froemming, L. M. S.; Pieper, G. W.; Pieper, N. W. Hospitabilidade e Lazer como fatores de satisfação de visitantes em feiras e exposições. Rev. Adm. IMED, v. 4, p. 13, 2014

[28] Lima, C. O.; SÁ, M. A. D.; Rodrigues, M. A.; Cavalcanti, E. P.; Oliveira, L. M. B. Feira da Sulanca em Caruaru-PE: Um Palco Cultural para as Representações Simbólicas entre Compradores e Vendedores. In: EMA, 2012.

[29] Machado, S. F.; Filho, R. E. F. A Feira de Artesanato em Pedra Sabão, como produto turístico, na perspectiva dos artesãos, Ouro Preto: Revista Acadêmica do Observatório de Inovação do Turismo, v. 8, p. 39-65, 2014.

[30] Mattson, J. D.; Clark, S. Human dignity in concept and practice. Policy Sei, 44, 303-319, 2011.

[31] Miranda, G. M. S. A feira na cidade: limites e potencialidades de uma interface urbana nas feiras de Caruaru e de Campina Grande. Dissertação de Mestrado da UFPE, Recife, 2009

[32] Nordenfelt, L. Dignity and the Care of the Elderly. Medicine, Health Care and Philosophy, v.6, p. 103-110, 2003.

[33] Nordenfelt, L. The Varieties of Dignity. Health Care Analysis, v.12, 69-81, 2004.

[34] Oliveira, S. R.; Missagia, S. V. O Mercado de Alimentação Local e a Configuração da Feira Livre do Produtor. EMA, 2014. 
[35] Pereira Junior, F. Feira de Campina Grande. Um museu vivo da cultura popular e do folclore nordestino. Editora Universitária/UFPB, 1977

[36] Ross, R. F. S. Bread and Roses: Women Workers and the Struggle for Dignity and Respect. The journal of labor \& society, v. 16, n. March, p. 59-68, 2013.

[37] Sá, M. G. De. Feirantes: Quem São? Como Administram seus Negócios? In: XXXIV Encontro da ANPAD, Rio de Janeiro: 2010.

[38] Sales, A. P.; Rezende, L. T.; Sette, R. S. Negócio feira livre: um estudo em um município de Minas Gerais. In: III Encontro de Gestão de Pessoas e Relações de Trabalho, João Pessoa, p. 15, 2011.

[39] Samara, B.S.; Morsh, M.A. Comportamento do Consumidor: Conceitos e Casos. Porto Alegre: Pearson, 2005

[40] Sarlet, I. Dignidade da Pessoa Humana e Direitos Fundamentais na Constituição Federal (8ed.). Porto Alegre: liv. do advogado, 2010.

[41] Siqueira, J. P. L.; Gaspar, M. A.; Telles, R.; Lollo, R. M. Gênese e evolução de um agrupamento de negócios varegistas: estudo de caso da feira das flores do CEAGESP. Revista Capital Científica-Eletrônica, n. 3, v. 12, p. 59-74, 2014.

[42] Souza, D. H. B.; Dantas, J. C.; Matias, T. B. O.; Moreira, E. Feira Livre e Cul. Pop.:Espaço de Resistência ou de Subalternidade? In: VII Congresso Bras. de Geógrafos. Anais do VII CBG-ISBN: 978-85-98539-04-1. Vitória/ES, 10 a 16 de Ag.de 2014

[43] SOUZA, M. M. P.; Almeida, G. O.; Pimentel, T. D. A construção de Identidades e Estratégias na Feira do Jubileu em Congonhas. Belo Horizonte: In: V Encontro de Estudos Organizacionais da ANPAD, 2008a.

[44] Souza, M. M. P.; Almeida, G. O.; Pimentel, T. D. Dimensão Identitária em duas Feiras Hippies: uma Comparação Etnográfica entre Estados Unidos e Brasil. Enanpad, 2008b.

[45] Souza, R. M. B.; Tolfo, S. R. Significados atribuídos ao trabalho em condições precárias: Um estudo com feirantes do Largo da Ordem de Curitiba-PR. Dissertação de Mestrado defendida no programa de pós graduação em Psicologia, 2009.

[46] Souza, Y. S. Aprendizagem Organizacional: Um estudo sobre feiras \& eventos como oportunidades para a cadeia coureiro-calçadista do Vale do Rio dos Sinos. EnANPAD, 2001.

[47] Tadd, W.;Vanlaere, L.; Gastmans, C. Clarifying the Concept of Human Dignity in the Care of the Elderly: A dialogue between empirical and Philosophical Approaches. Ethical Perspectives, v. 17, n.1, p. 253-281, 2010

[48] Teixeira, M. L. Dignidade Organizacional: valores e relações com stakeholders. In: Valores Humanos e Gestão: novas perspectivas. Sao Paulo: SENAC, 2008.

[49] Veiga, C. H. A.; Lima, J. M.; Zanon, L. B. Feira de negócios internacionais: uma proposta de, jogos de empresas vivenciais em aula. Internex T-Revista Eletrônica de Negócios Internacionais da ESPM, v. 8, p. 127-144, 2013. 


\section{Capítulo 9}

\section{A formação do Professor Indígena sob o viés da interculturalidade}

\section{Simone Rodrigues Batista Mendes}

Resumo: 0 texto traz uma reflexão a partir da questão norteadora: no contexto político e pedagógico o professor indígena é fundamental no processo de construção do diálogo intercultural, mediando e articulando os conhecimentos e saberes de interesse da comunidade, do seu povo e da sociedade, suscitando a estruturação e organização de novos saberes e práticas. Como você compreende esse papel? Discutida no tema Formação de Professores do Curso de Licenciatura Intercultura da (UFRR), pressupondo a compreensão do diálogo intercultural entre as sociedades e os diferentes, trazendo perspectivas e possibilidades para formação dos sujeitos. Pesquisa tendo como lócus à sala de aula, abordagem qualitativa com análise descritiva e como sujeitos os acadêmicos do curso de Licenciatura Intercultural. (UFRR). Como resultado foi possível considerar a partir das falas dos sujeitos que, há consciência da responsabilidade do professor indígena no processo de construção do diálogo intercultural, sendo ele um mediador e articulador dos conhecimentos e saberes de interesses da comunidade, do seu povo e a sociedade, suscitando a estruturação e organização de novos saberes e práticas. De modo que, a interculturalidade é assentida como direito, resultado da resistência, das lutas dos movimentos e lideranças indígenas, uma conquista de direitos que foram usurpados (língua, cultura, hábitos e crenças).

Palavras-chave: Formação de Professores Indígenas, Interlocução, Interculturalidade. 


\section{INTRODUÇAO}

Ao longo da história, a educação indígena do estado de Roraima foi aventada no contexto da política educacional global, seguindo mesmo das escolas dos não indígenas, definindo-se a partir do interesse do Estado e guiada pelas diretrizes adotadas em todo o país, uma concepção e currículo que não levava em conta suas especificidades. Nos dias atuais assegura-se aos povos indígenas uma educação que afirme e/ou reafirme sua identidade, suas línguas, crenças e costumes, uma educação na perspectiva intercultural. Para isso o Estado criou e vem criando projetos e programas com objetivo de resguardar seus direitos e valorizar a cultura.

A Lei de Diretrizes e Base da Educação de 1996 "garante aos índios o acesso ao conhecimento proveniente de uma educação especializada, com programas e currículos específicos". Com o incremento educação escolar indígena, a formação de professores tem se tornado uma preocupação para povos, que vem buscando compreender o significado de uma formação específica diferenciada, bilíngue, intercultural, com vistas, a construção uma escola nessa mesma perspectiva.

Nas últimas décadas a taxa de crescimento populacional dos povos indígenas do estado tem aumentado significativamente, obrigando os sistemas (federal, estadual) criar e implantar escolas para atender esta demanda. Diante desse contexto, cresce também a necessidade de formação professores e expansão do ensino superior. Atendendo os anseios e reinvindicações a Universidade Federal de Roraima (UFRR) cria a Licenciatura Intercultural, curso elaborado com a participação dos povos indígenas de Roraima. Nesta perspectiva Baniwa (2006), afirma que,

Nos últimos dez anos, foram formados ou estão em formação em cursos específicos de Magistério Indígena, cerca de 8.000 professores indígenas em quase todos os estados Brasil. Esse novo contingente de atores e de lideranças constitui para mobilizar povos indígenas, junto as munícipios e os estados, na busca por implementação de escolas em suas comunidades. Desde a década de 1990 vem ocorrendo uma multiplicação de organizações indígenas em todos país. (BANIWA, 2006, p.141)

Assim, formar professores com a habilidade de diálogo, com vistas à interlocução entre comportamentos e conhecimentos distintos tem sido uma altercação para os cursos de formação de professores indígenas. Nesse sentido o texto apresenta uma reflexão a partir da questão norteadora: No contexto político e pedagógico o professor indígena é fundamental no processo de construção do diálogo intercultural, mediando e articulando os conhecimentos e saberes de interesses da comunidade, do seu povo e a sociedade, suscitando a estruturação e organização de novos saberes e práticas.

A questão foi aplicada a turma matriculada no tema Formação de Professores (FPE4) do curso de Licenciatura Intercultural, ofertado pelo Instituto de Formação de Superior Indígena Insikiran (UFRR). 0 tema consta do currículo e compõe o núcleo de formação pedagógica especifica do curso, onde são "abordados os temas mais relevantes para a formação do professor, os quais foram levantados a partir de várias assembleias e seminários promovidos em parceria com as lideranças, professores, comunidades indígenas e as instituições participantes" (PPP - Licenciatura Intercultural, 2008, p.22-23).

Os resultados das análises e discussões são provenientes da reflexão sobre a experiência vivenciada no decorrer do desenvolvimento do componente curricular (FP04) do curso em questão e buscou compreender diante a afirmativa como ele se vê nesse papel do professor indígena frente a sua comunidade e povo? Como referencial usou-se dos documentos oficiais Referencial Curricular Nacional para Escolas Indígenas (2005) e Diretrizes Nacionais para Educação Básica (2010) para a questão interculturalidade apoiou-se em Candau (2014), Grupioni (2002) e Ouellet (1991).

\section{FORMAC̣ÃO DE PROFESSORES INDÍGENAS E A INTERCULTURALIDADE}

A conquista da formação específica para professores indígenas é resultado do processo de luta e reinvindicações dos povos indígenas, sendo, portanto, as políticas de formação consequências de mais de 50 anos de resistência das lideranças e organizações indígenas. Desde sempre o professor exerceu e, ainda exerce, um papel central na construção político-social da sociedade, seu papel que vai além do ato de ensinar, pois sua pratica docente não está dissociada da pratica social, de modo que numa sociedade transitória e complexa como atual, exige-se do professor uma formação consciente que propiciei a quebra de paradigmas e construção de novos conhecimentos e saberes.

Nesse contexto, foi criado o Núcleo Insikiran de Formação de Professores Indígenas da Universidade 
Federal de Roraima, aprovado por unanimidade em 25 de julho de 2001, pelo Conselho de Ensino, Pesquisa e Extensão (CEPE) e, no mesmo ano o Conselho Universitário (CUNI) instância máxima da universidade, também o aprovou. Concretizando e atendendo a uma reinvindicação dos povos indígenas do Estado, na luta pela autodeterminação dos povos indígenas, a gênese da formação do professor está na construção de conhecimentos e saberes que os auxiliem na construção de uma prática docente transformadora e libertária.

A palavra Insikiran tem origem na mitologia dos povos indígenas que jazem no Monte Roraima (montanha situada na tríplice fronteira Brasil, Venezuela e Guiana), para o povo Macuxi, significa dizer ser um dos filhos guerreiros do Makunaimî e irmão de Anikê, personagens da cosmologia destes grupos étnicos. Cabe informar ainda que a UFRR é a primeira instituição federal de ensino superior a implantar cursos específicos de graduação para a formação de indígenas

Fotos 01 e 02: Visão Panorâmica do Instituto Insikiran (UFRR)
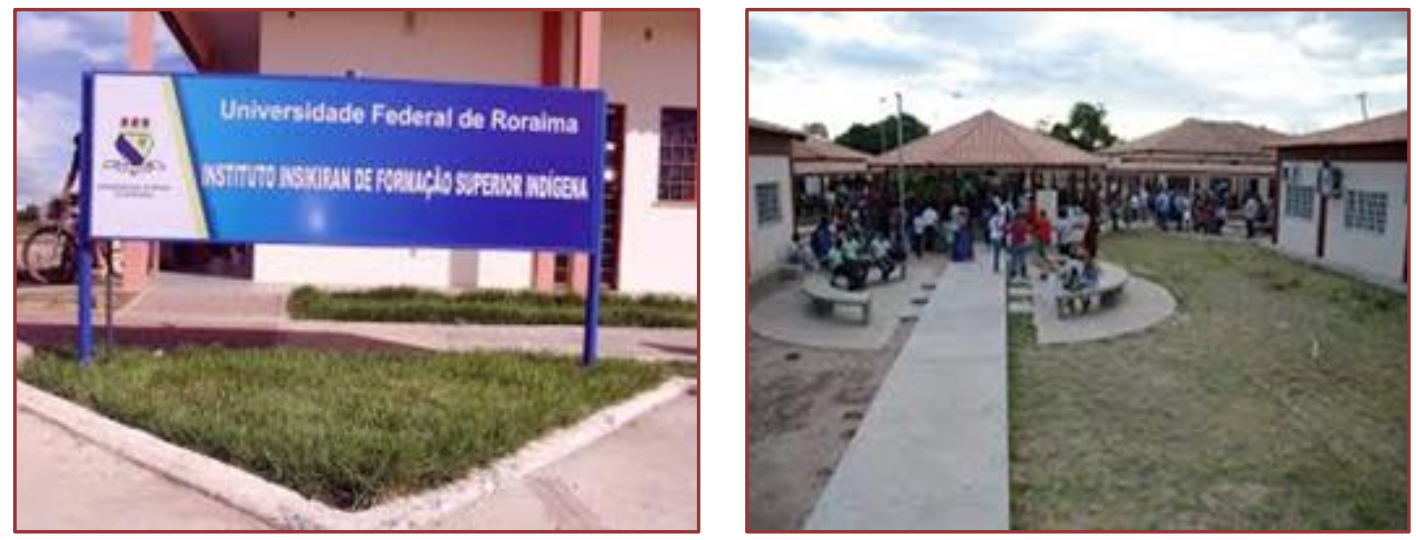

Fonte: Site UFRR/INSIKIRN (20/05/19)

A palavra Insikiran tem origem na mitologia dos povos indígenas que jazem no Monte Roraima (montanha situada na tríplice fronteira Brasil, Venezuela e Guiana), para o povo Macuxi, significa dizer ser um dos filhos guerreiros do Makunaimî e irmão de Anikê, personagens da cosmologia destes grupos étnicos. Sendo a UFRR é a primeira instituição federal de ensino superior a implantar cursos específicos de graduação para a formação de indígenas.

Com a criação do Instituto deu-se a início à formação superior específica para professores indígenas, um ingresso legal e legítimo. O Instituto Insikiran é composto por três cursos: Licenciatura Intercultural, Gestão Territorial Indígena e Gestão em Saúde Coletiva Indígena. A Licenciatura Intercultural foi o primeiro curso do Instituto, fruto da luta das lideranças, professores indígenas, do Conselho Indígena de Roraima (CIR) e da Organização dos Professores indígenas de Roraima (OPIR) uma reinvindicação para o ensino superior, pois até então o estado de Roraima só ofertava formação específica para professores indígenas em nível médio modalidade normal.

O curso tem como objetivo "formar e habilitar professores indígenas em Licenciatura Plena "com enfoque intercultural, com áreas de concentração em Ciências Sociais, em Comunicação e Artes ou em Ciências da Natureza". Apresenta o enfoque intercultural como processo de construção do dialogo das sociedades e culturas, uma visão que pressupõe a melhoria da "qualificação do ensino escolar das comunidades, que poderá ser "alcançada se os professores receberem uma formação diferenciada, voltada para a realidade específica em que se inserem, assim como pelo seu próprio esforço por construir novos conhecimentos". (PPP - Licenciatura Intercultural, 2008, p.18).

A formação de professores indígenas na perspectiva intercultural centra-se nos princípios da educação escolar indígena, implicando no desenvolvimento da proposta da educação intercultural prevista na legislação vigente como: LDB/1996, pareceres e resoluções do Conselho Nacional de Educação - CNE e, em documentos como: Referencial Curricular Nacional para Escolas Indígenas (2005), Diretrizes Nacionais para Educação Básica e reivindicada pelos povos indígenas. "Formar professores indígenas [...] é hoje um dos principais desafios e prioridades para consolidação de uma Educação Escolar Indígena pautada nos princípios da diferença, da especificidade, do bilinguismo e da interculturalidade”. (DCNs, 2013, p.376.) 
Da situação de contato com outro, fez-se a necessidade de uma a educação intercultural, cabendo ao professor o papel central da interlocução desse diálogo intercultural e da mediação do processo de interação entre os diversos conhecimentos. Para Nascimento (2014) essa é uma das razões para que "os processos de reafirmação de identidades através de reivindicação do reconhecimento da diversidade tem sido cada dia mais frequentes e, em alguns aspectos, esta política de reivindicação estimula e por vezes até exige o reconhecimento". (p.36)

A formação inicial dos professores indígenas deve ocorrer em cursos específicos de licenciatura e pedagogia intercultura [...] e, enfatizar a constituições de competências referenciadas em conhecimentos. É, portanto, por meio desta formação especifica que se espera a firmação de identidades, se tornando assim, a chave para o processo de construção de identidades coletivas que partem do reconhecimento da diversidade. (Resolução 05 /2012/CBE/CNE).

Dessa forma um dos fundamentos é interculturalidade, esta deve permear todo processo dessa formação. Segundo Grupioni (2002, p.87) "uma formação intercultural está pautada na diversidade de culturas, nas riquezas de conhecimentos, saberes e práticas a ela associadas". Ouellet (1991) reforça este pensamento quando afirma que, este modelo baseia-se em uma formação que assinala a compressão das culturas, das relações, da capacidade de comunica-se com a diversidade cultural, sociopolítica, e na capacidade de interação social. Uma formação concebida com este enfoque intercultural instrumentaliza o professor para interferir e intervir no meio que o cerca.

O curso tem duração de quatro anos e meio e está organizado com seguinte formato: dois anos de formação Pedagógica (núcleo comum) "cuja abordagem perpassa uma orientação pedagógica específica articulada com as três áreas de concentração, a serem cursadas nos últimos anos: Ciências Sociais, Comunicação e Artes ou Ciências da Natureza". (PPP - Licenciatura Intercultural, 2008, p.22-23). E apresenta a seguinte formatação:

Figura 01

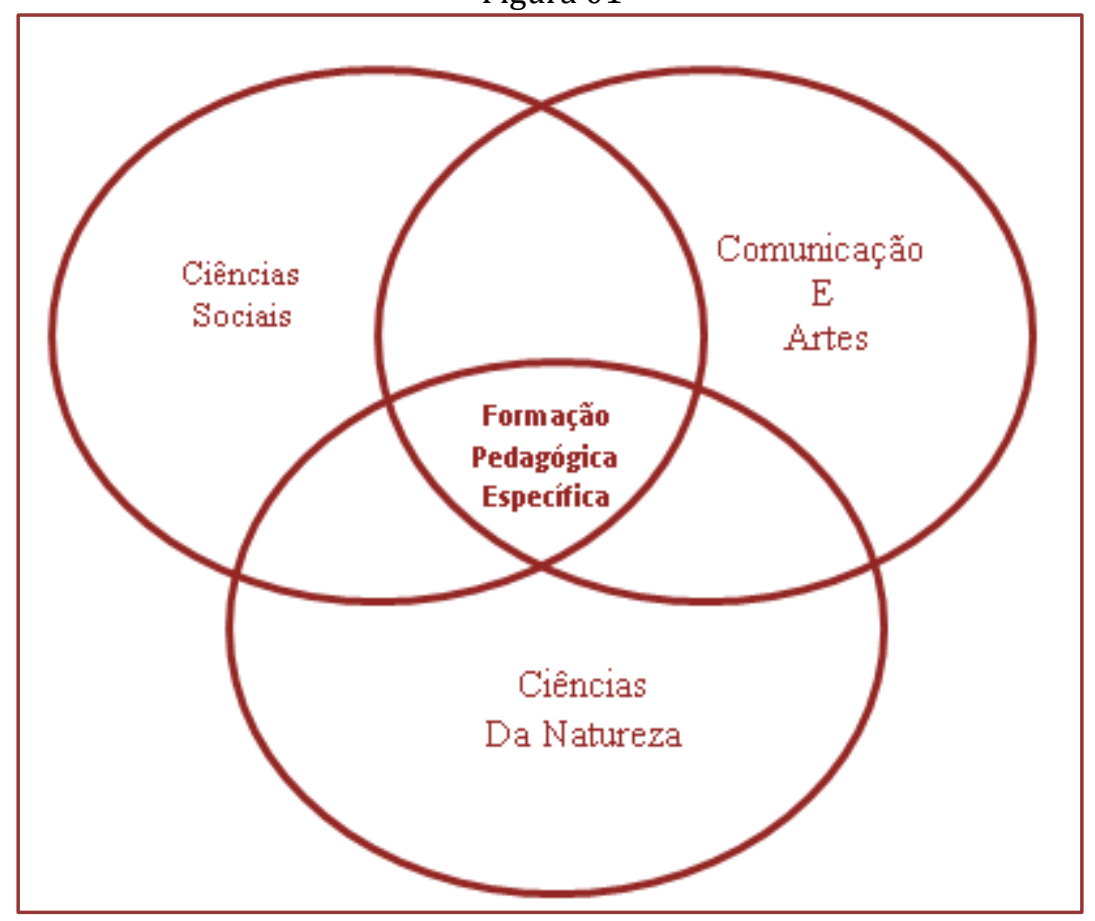

Fonte: (PPP - Licenciatura Intercultural, 2008, p.08).

0 quadro 01 apresenta o resumo dos temas contextuais que são ministrados nos dois primeiros anos, que são o alicerce da formação pedagógica, temas centrais que objetivam "atender à necessidade de uma escola que responda às especificidades do processo histórico vivenciado pelos povos indígenas, buscando qualidade na sua formação". (P. 8). Os temas que compõem o eixo especifico são as chamadas pedagógicas 
e tem papel de fortalece e dar base a pratica docente professor. A seleção dos temas partiu dos interesses e das necessidades específicas das comunidades indígenas participantes. (PPP - Licenciatura Intercultural, 2008, p.22-).

\section{Quadro 01}

\begin{tabular}{|c|c|c|}
\hline \multicolumn{2}{|c|}{ Tema Contextual } & Abreviatura \\
\hline $\begin{array}{c}\text { Fundamentos Legais da Educação } \\
\text { Escolar Indígena }\end{array}$ & FPE1 & $144 \mathrm{~h}$ \\
\hline $\begin{array}{c}\text { Fundamentos Pedagógicos da Educação } \\
\text { Escolar Indígena }\end{array}$ & FPE2 & $144 \mathrm{~h}$ \\
\hline $\begin{array}{c}\text { Sistemas de Ensino e Gestão Escolar } \\
\text { Indígena }\end{array}$ & FPE3 & $144 \mathrm{~h}$ \\
\hline Formação de Professores & FPE4 & $144 \mathrm{~h}$ \\
\hline Material Didático I & FPE5 & $144 \mathrm{~h}$ \\
\hline
\end{tabular}

Fonte: PPP - Licenciatura Intercultural, 2008, p.38).

O núcleo de formação pedagógica especifica objetiva promover a construção de conhecimentos teóricopedagógico que fortaleça a construção de conhecimentos e saberes que desenvolva a visão de mundo e de sua de história, e ainda alargar a capacidade crítica da realidade que está inserido, possibilitando a construção cognitiva que realiza o sujeito. De modo que segundo MEIRIEU, 1998, p. 41 “ [...] que domine o "conhecível", que explore, em todos os sentidos, os conhecimentos que deve fazer com que sejam adquiridos, que compreenda suas gêneses e suas lógicas, que examine todos os recursos que elas oferecem e que busque, sobretudo, todas as abordagens, todos os caminhos que lhe permitam ter êxito".

Para Zabala (2004, p.111), a formação pedagógica do professor permite acima de tudo a compreensão que o ato de "Ensinar é uma tarefa complexa na medida em que exige um conhecimento [...] acerca da maneira como os estudantes aprendem, acerca do modo como serão conduzidos os recursos de ensino a fim de que se ajustem melhor às condições em que será realizado o trabalho".

\section{PERCURSO METODOLOGICO}

A pesquisa foi realizada com acadêmicos da Licenciatura Intercultural da (UFRR), matriculados no tema Contextual Formação de Professores Indígenas (FPE4), componente que constitui a matriz da formação pedagógica do curso, conforme descreve o PPC do Curso (2008, p. 41) visa a " compreensão do papel do professor na comunidade indígena em relação às demandas internas e externas". Para tanto, adotou-se uma abordagem qualitativa, e, entendendo que "enquanto exercício de pesquisa, abordagem qualitativa não se apresenta como uma proposta rigidamente estruturada, ela permite que a imaginação e a criatividade levem os investigadores a propor trabalho" (GODOY, 1995, p.21).

Com relação ao objetivo tem-se um estudo analítico descritivo. Análise dos dados a partir da avaliação inicial (instrumento aplicado no início das atividades). Para relatar tem a configuração (Acadêmico 01), com reprodução da fala na integra do sujeito, respeitando sua escrita na integra.

Como instrumento foi usado à avaliação inicial (caráter diagnóstica) aplicada no início do tema com o propósito de descobrir os conhecimentos prévios e, também dos conceitos básicos que permeiam a formação, haja vista, que turma estava finalizando o bloco formação pedagógica específica, primeira etapa do curso. A avaliação inicial teve como finalidade conhecer e analisar a formação de professores indígenas no contexto da interculturalidade.

Para Hoffmann (2003, p.15) "a avaliação é essencial à educação. Inerente e indissociável enquanto concedida como problematização, questionamento e reflexão sobre a ação", por conseguinte, compreendese avaliação diagnóstica como instrumento de auxílio à identificação de dificuldades específicas e lacunas na apreensão do conhecimento. Além do que, permite ao professore conhecer a realidade da turma, observar competências e habilidades, pré-requisitos para os processos de ensino e aprendizagem. 
Reforçando Hoffmann (2003), Vasconcelos (1996, p.65) afirma que:

É necessário vincular a aquisição do saber as realidades sociais e aos interesses dos alunos de forma que eles possam compreendê-los, ou seja, articular o saber escolar com as necessidades concretada da vida desses alunos. È necessário compreender que a pratica educativa é condicionado pelo tempo histórico que caracteriza a sociedade.

Seguindo o pensar de Vasconcelos (1996) a avaliação inicial foi estruturada, buscando notar conhecimentos e saberes apreendidos, compreender a realidade da turma e perceber a conceitos e concepções trazidas em sua bagagem. 0 instrumento foi organizado em quatro questões abertas dissertativas, trazendo a questão que norteou o estudo reflexivo: no contexto político e pedagógico o professor indígena é fundamental no processo de construção do diálogo intercultural, mediando e articulando os conhecimentos e saberes de interesses da comunidade, do seu povo e a sociedade, suscitando a estruturação e organização de novos saberes e práticas.

A questão norteadora teve como objetivo possibilitar o acadêmico refletir como ele compreender esse papel do professor indígena frente a sua comunidade e povo? Ressaltando que os sujeitos do curso já são professores da Rede Estadual e/ou Municipal, portanto trazem consigo saberes e experiência da docência e, também grandes questionamentos sobre a prática docente e o trabalho nas escolas de suas comunidades.

\subsection{RESULTADOS E DISCUSSÃO}

Para maior compreensão do estudo traçou-se o perfil da turma e para melhor visualização do resultado do trabalho. A turma constituída por 26 acadêmicos sendo: 10 homens e 16 mulheres, desses nem todos são falantes da língua. A maioria já em pleno exercício da docência e, com experiência acima de três anos, do total somente 03 não estão em sala de aula. 0 estado de Roraima apresenta nove etnias sendo: Yanomani, Macuxi, Taurepang, Ingarikó, Wai-wai, Patamona, Wapixana, Waimiri-atroari e Yekuana (Mayongong). Ressaltado que, os Macuxi tem maioridade populacional no estado. Das nove etnias do estado três se faziam presente na sala de aula:

O Povo Macuxi tem de são originários do Karib, estão situam-se nas regiões do estado, com uma população aproximadamente 18 mil pessoas e sua bandeira de luta há mais de 20 anos pela demarcação de suas terras. Os Ingarikó, também de origem no Karib, concentram-se no extremo norte de Roraima, entre as fronteiras da Venezuela e Guiana, aproximadamente mil pessoas e vivem em estado semi-isolado. Eles se autodenominam KAPON "Gente do céu”. Wapixana, origunários do Arawak, concentram-se a norte e leste do estado, principalmente na fronteira com Guiana, com uma população 8 mil pessoas, eles mantêm viva sua cultura através de suas danças e suas comidas. (fonte:http://ideazdodeserto.blogspot.com/2010/10/indios-emroraima-outras-etnias.html)

O quadro 02 nos auxilia na compreensão do contexto intercultural vivenciado em sala de aula, uma grande provocação para professor formador da turma, são oriundos das diversas regiões e comunidades localizadas nas terras indígenas do estado, demonstrando o desafio da formação de professores, para instituição. A priori há salas de aula com mais de 5 etnias, sendo essa é uma realidade vivenciada pelo curso.

Quadro 02

\begin{tabular}{|c|c|c|}
\hline Etnias & Quantidade & Falante da Língua \\
\hline Macuxi & 13 & 02 - Falante \\
\hline Wapixana & 06 & 03 - Faltante \\
\hline Ingarikó & 01 & 01 - Falante/escreve \\
\hline
\end{tabular}

Quadro - elaborado pela pesquisadora 
O fato de muitos não falarem a língua não diminui a presença da interculturalidade, são três povos com hábitos, costumes, crenças, não os faz deixar de serem índios, levando-se em conta como se deu o processo de contato, presença da igreja e o processo de escolarização e, que os indígenas foram obrigados a se tornarem monolíngues em português. Não esqueçamos:

A introdução da escola a foi um dos principais instrumentos empregados para promover a domesticação dos povos indígenas, promovendo sua integração na comunhão nacional, desprovidos de suas línguas maternas e de seus atributos étnicos e culturais. (GRUPIONI, 2006, p.43)

Instrumento de opressão no passado, hoje a escola é uma das ferramentas para lhes devolver o sentimento de pertencimento, mas, uma escola que respeite e valorize os seus modos próprios de viver. Com esse olhar, a formação de professores indígenas é uma forma de fortalecer e consolidar a educação escolar indígena alicerçada nos princípios da diferença, especificidade, bilinguismo e da interculturalidade.

Nesse sentido, buscou-se perceber qual a compreensão dos acadêmicos em relação ao papel do professor como um dos principais interlocutores na construção do dialogo intercultural, a partir da visão da intercultrualidade critica de Candau (2014):

A interculturalidade critica [...] promove a deliberada inter-relação entre os diferentes sujeitos e grupos socioculturais presentes em uma sociedade. [...] posição que rompe com uma visão essencialista das culturas e das identidades culturais; concebe as culturas em continuo processo de construção, desestabilização e reconstrução; está constituída pela afirmação de que nas sociedades em que vivemos os processos de hibridização cultural são intensos e mobilizadores de identidades abertas, [...] assume que não são relações idílicas, não relações românticas, estão construídas na história. (p.28)

Nessa perspectiva, compreende-se que para um assumir uma postura intercultural e, também um diálogo nessa direção o professor indígena, precisa apreender a essência dos processos em que está envolvido socialmente e historicamente, de modo que, a interculturalidade alicerçará sua prática docente frente ao contexto de diferenças e desigualdades dentro próprio cenário dos povos indígena (língua, cultura, hábitos).

Este sujeito político necessita ter um olhar para as diferenças construídas ao longo da história das próprias comunidades. Segundo Urquiza et Nascimento (2010) “ao conquistarem o direito a uma escola específica e diferenciada, multicultural e comunitária os povos indígenas abrem um campo [...] no qual, movimentam-se como protagonistas, no sentido de pensar [...] a lógica do diálogo entre os seus saberes e os saberes legitimados historicamente pela cultura escolar. (p.46)

0 quadro 03 apresenta a percepção de três acadêmicos sobre o protagonista e ter a responsabilidade de ser um dos principais interlocutores na construção do diálogo intercultural. No texto, as falas dos acadêmicos estão identificadas por números e a avaliação inicial também, que não corresponde ao número da lista de frequência, somente uma forma de identificação para análise.

\section{Quadro 03}

\begin{tabular}{|c|c|}
\hline Falas & Observação \\
\hline $\begin{array}{l}\text { È no cotidiano que se aprende o habito de interagir } \\
\text { numa sociedade não indígena, trocando ideias } \\
\text { juntamente com os pensamentos de cada povo o } \\
\text { indígena se vai construindo história e pesquisando a } \\
\text { vivência de cada cultural diferente. [...]. (Acadêmico 02, } \\
\text { 2018, avaliação inicial no } 08 \text { ) }\end{array}$ & $\begin{array}{l}\text { Dia a dia sendo visto como espaço de } \\
\text { aprendizagem e interação com comunidade e outras } \\
\text { sociedades; } \\
\text { - Vivencia com vários povos e outras culturas como } \\
\text { oportunidade de trocar de ideias e novas experiências. }\end{array}$ \\
\hline $\begin{array}{l}\text { Sim, concordo que os professores são importantes nesses } \\
\text { processos todos, na verdade esse é o papel do professor } \\
\text { articulador, mediador, pesquisador e principalmente ter } \\
\text { um grande compromisso com ele mesmo para assumir a } \\
\text { responsabilidade que lhe cabe. (Acadêmico 14, 2018, } \\
\text { avaliação inicial no } 20 \text { ) }\end{array}$ & $\begin{array}{l}\text { O professor se reconhece o como um sujeito } \\
\text { imprescindível na construção dos diálogos; } \\
\text { Aceita o compromisso de ser mediador e } \\
\text { articulador, uma responsabilidade assumida com seu } \\
\text { povo, comunidade e consigo mesmo. }\end{array}$ \\
\hline $\begin{array}{l}\text { O professor precisa saber os processos de construção do } \\
\text { diálogo com as comunidades, com várias instituições, } \\
\text { articulando conhecimento e também os saberes de seu } \\
\text { povo e comunidade com os outros grupos particulares } \\
\text { [...]. (Acadêmico } 10,2018 \text {, avaliação inicial no } 23 \text { ) }\end{array}$ & $\begin{array}{l}\text { O professor preciso o conhecer como funciona } \\
\text { processo de articulação; } \\
\text { Dever conhecer o processo para poder articular } \\
\text { com os saberes indígenas. }\end{array}$ \\
\hline
\end{tabular}


As narrativas extraídas das avaliações demonstram que os acadêmicos assumem discurso dos povos indígenas e dos documentos oficiais sobre seu papel social, ou seja, a comunidade espera desse um sujeito conhecimento e saberes que os permitam dialogar, portanto, é de sua responsabilidade a construção das relações e do diálogo sócio-político entre eles e entre as outras sociedades. Vale ressaltar que, na discussão em sala os sujeitos assim entendem, contudo ainda, para eles é um grande desafio fazer interlocução e ainda, mediar conhecimentos e saberes, percebe-se que alguns já fazem esse papel pois, são coordenadores pedagógicos de regiões e/ou representantes de suas comunidades em assembleia, reuniões encontros de lideranças, contudo outros aprestam uma timidez e se restringem- se ao papel único de professor.

De acordo com Candau (2010) uma formação “[...] a perspectiva intercultural procura estimular o diálogo entre os diferentes saberes e conhecimentos, e trabalha a tensão entre universalismo e relativismo no plano epistemológico, assumindo os conflitos que emergem deste debate". (p. 764). Na mesma direção Urquiza et Nascimento (2010,p.26) nos afirma que, "mais especificamente o professor indígena, neste novo modelo, passa a ocupar um lugar central, levando em consideração as especificidades de cada povo, nos processos de repensar a realidade das comunidades indígenas na convivência em sempre harmônica com a chamada "sociedade nacional".

\section{CONCLUSÃO}

Na análise e discussão foi possível perceber que para estes sujeitos o papel do professor indígena ainda é um papel social complexo, pois implica acima de tudo se reconhecer culturalmente e, também se reconhecer no contexto multiétnico. É desafiador transitar entre as sociedades, e fazer a comunidade compreender essa interação é uma das suas reponsabilidades, enquanto professor, liderança, educador e sábio. A interlocução requer conhecimentos, saberes e postura política, necessitando a compreensão das diferenças socioculturais entre os povos e, também entre sociedades.

0 discurso da intercultrualidade é recorrente, entretanto ainda, não se percebe como atitude, sendo assumido muito a partir dos documentos oficiais, principalmente a legislação. Há consciência da responsabilidade do professor indígena no processo de construção do diálogo intercultural, mediando e articulando os conhecimentos e saberes de interesses da comunidade, do seu povo e a sociedade, suscitando a estruturação e organização de novos saberes e práticas. De modo que, a interculturalidade é assentida como direito resultado da resistência e das lutas dos movimentos e lideranças indígenas, uma conquista de direitos que foram usurpados (língua, cultura, hábitos e crenças).

\section{REFERÊNCIAS}

[1] Brasil. Lei no 9.394, de 20 de dezembro de 1996. Lei de Diretrizes e Bases da Educação Nacional. Disponível em: <http://portal.mec.gov.br/arquivos/pdf/ldb.pdf>. Acesso em: 23/07/18.

[2] Brasil. Diretrizes Curriculares Nacionais para Educação Indígena. Brasília: Ministério da Educação, 2013.

[3] Godoy, A. S. Pesquisa qualitativa: tipos fundamentais. Revista de Administração de Empresas, São Paulo, v.35, n. 3 , p. $20-29,1995$

[4] Grupioni, L. D. B. (org.). O estado da arte da formação de professores indígenas no Brasil: formação de professores indígenas: repensando trajetórias. Brasilia: MEC, 2006.

[5] Hoffmann, J.M.L. Avaliação: mito e desafio: uma perspectiva construtivista. Porto Alegre, RS: Mediação, 2003.

[6] Meirieu, P. Aprender... sim, mas como?. Porto Alegre: Artmed, 1998.

[7] Moreira, F.A. Candau, V.M. Currículos, disciplinas escolares e culturas. Petrópolis, RJ: Vozes, 2014.

[8] Ouellet, Fernando. O Que quero dizer quando penso em Educação Intercultural. Faculdade de Teologia e Filosofia da Universidade de Sherbrooke, Canadá: 1991. Disponível em <http://www.entreculturas.com.br>. Acesso dia $27 / 06 / 18$.

[9] Roraima, Universidade Federal de Roraima. Projeto Político-Pedagógico do Curso de Licenciatura Intercultrual.. Boa Vista, RR: UFRR, Instituto Insikiran, Versão, 2008.

[10] Vasconcelos, Celso dos Santos. Avaliação da Aprendizagem: práticas de mudança. Por uma práxis transformadoras. São Paulo: Libertad, 1996.

[11] Urquiza, A. H. A., Nascimento, A. C. O desafio da interculturalidade na formação de professores indígenas. Espaço Ameríndio, Porto Alegre, v. 4, n. 1, p. 44-60, jan. /jun. 2010. Disponível em <www.seer.ufrgs.br/EspacoAmerindio/article/download/12741/8124>. Acesso em 20/06/18.

[12] Zabalza, M. A. O ensino universitário: seu cenário e seus protagonistas. Porto Alegre: Artmed, 2 


\section{Capítulo 10}

\section{Currículo escolar em contexto Amazônico: Qual espaço dos saberes locais no currículo?}

\section{Kézia Siméia Barbosa da Silva Martins}

\section{Zildiane Souza Teixeira}

Resumo: Tendo como referência os estudos investigativos realizados no Mestrado e Doutorado (2010-2016) pelo Programa de Pós-Graduação em Educação - PPGE/UFAM, pesquisando e orientando estudantes de graduação sobre os saberes locais e sua inserção no currículo escolar na perspectiva de repensar e dar novos significados às práticas curriculares, este artigo pretende descrever os resultados de alguns questionamentos suscitados a partir do contato com docentes colaboradores das escolas que durante a trajetória de pesquisas em campo participaram com dados que geraram debates, inquietações e proposições para estudos no campo do Currículo escolar e os Saberes Locais, sobretudo, na realidade das escolas de Ensino Fundamental em Parintins-Amazonas. Há uma difusa e tensa discussão nas teorias do currículo sobre os conteúdos que realmente importam para serem desenvolvidos em sala de aula com os estudantes. Apple (2006), Moreira; Candau (2008), Santomé (1995), Ghedin (2006), Silva (2010), Moreira e Silva (1995), Geertz (1997), Lopes (1999), dentre outros os quais colocam em pauta posições que contestam a priorização dos saberes científicos e universais em detrimento dos saberes locais e singulares dos grupos culturais. Portanto, pensar um currículo escolar que atenda as distintas realidades é requerer o acesso às múltiplas experiências, valores, costumes e saberes diversos. Portanto serão socializados os resultados de entrevistas com 05 (cinco) docentes do $5 \underline{0}$ ano do ensino fundamental, articulados à observação realizada em sala de aula. Trata-se de uma reflexão sobre o espaço dos saberes locais do contexto amazonense nas práticas curriculares, salientando a necessidade de convivência entre o local e o universal, 0 singular e o diverso, pois é importante que o estudante encontre nos currículos vivenciados na escola a conexão com os elementos identitários que constituem as localidades amazônicas. Somente reformular conteúdos, aumentar ou diminuir disciplinas e ementas, seguir parâmetros, diretrizes, bases curriculares ou modificar metodologias, não darão conta das diferentes e complexas realidades que permeiam a escola.

Palavras-chave: Currículo Escolar, saberes locais, contexto amazônico. 


\section{INTRODUÇÃO}

"Nossa voz é apenas uma entre muitas, mas é a única que possuímos. É preciso descobrir uma maneira de fazer com que as várias manifestações desse saber se transformem em comentários uma das outras, uma iluminando o que a outra obscurece" (GEERTZ, 1997).

Ao olhar as interações dos múltiplos conhecimentos e vivências educativas no âmbito da escola, é necessário (re) discutir um currículo que não se configure, sobretudo, como um rol de disciplinas, um produto acabado, desvinculado da experiência dos alunos e das realidades sociais. Problematizar sobre os conteúdos escolares, refletir sobre as especificidades do currículo, analisar, interpretar e questionar as propostas curriculares que são efetivadas hoje nas escolas torna-se imprescindível para compreender que o currículo é determinado pelo contexto e deve possibilitar o diálogo entre os diversos saberes que permeiam a sociedade.

Portanto, tendo como referência os estudos investigativos realizados desde o Mestrado e Doutorado em Educação (2010-2016) pelo Programa de Pós-Graduação em Educação - UFAM, pesquisando sobre os saberes locais e sua inserção no currículo escolar, na perspectiva de repensar e dar novos significados às práticas curriculares, este artigo pretende descrever os resultados de alguns questionamentos suscitados a partir do contato com docentes colaboradores de 01 (uma) das 10 (dez) escolas estaduais e municipais que durante a trajetória de pesquisas em campo participaram como lócus de pesquisa, subsidiados pelos dados que geraram debates, inquietações e proposições para estudos no campo do Currículo escolar e os Saberes Locais, sobretudo, na realidade das escolas de Ensino Fundamental em Parintins-Amazonas.

Sabe-se que há uma difusa e tensa discussão nas teorias do currículo sobre os conteúdos que realmente importam para serem desenvolvidos em sala de aula com os estudantes. Os efervescentes debates no campo das políticas curriculares comprovam a urgência de determinados grupos em reestruturar diretrizes, rever propostas, repensar conteúdos escolares. A Base Nacional Comum Curricular (BNCC), apresentada pelo Ministério da Educação (MEC) em 16 de setembro de 2015, documento que pretende nortear o currículo do ensino básico brasileiro afirma que serão estabelecidos $60 \%$ dos conteúdos a serem aprendidos na Educação Básica, deixando os outros 40\% para serem determinados regionalmente, considerando as escolhas de cada sistema educacional.

Mesmo as Bases Curriculares "Comuns" garantindo o espaço no currículo para mobilização valorização dos saberes regionais e locais, o que pode estar por trás é uma tentativa ilusória de reprodução dos interesses de grupos que querem ter sempre as rédeas e controle do que ensinar, como ensinar, aonde ensinar, como e quando ensinar. É necessário ficarmos atentos para que a concretização de tal política que permeia a BNCC não se configure como espaço fértil para o estreitamento curricular e controle das ações dos sujeitos da escola, dos conteúdos, das avaliações, da gestão etc. 0s $60 \%$ que são os conteúdos obrigatórios tendem a serem privilegiados e considerados legítimos, os quais serão cobrados nos testes de larga escala, em detrimento daqueles que estão no campo dos saberes regionais, locais, das vivências e experiências cotidianas dos estudantes. Acreditamos que seria social e culturalmente justo se um não abstraísse o outro.

Apple (2006), Moreira; Candau (2008), Santomé (1995), Ghedin (2006), Moreira e Silva (1995), Silva (2010) Geertz (1997), Lopes (1999), Esteban (2013), dentre outros, os quais colocam em pauta posições que contestam a priorização dos saberes científicos e universais, silenciando os demais saberes culturais locais. Pensar um currículo escolar que atenda as distintas realidades é requerer o acesso às múltiplas experiências, valores, costumes e saberes das diferentes localidades.

Portanto neste trabalho, especificamente, serão socializados resultados das percepções de 05 (cinco) professores do 5 ano do Ensino Fundamental, articulando-as à observação realizada em sala de aula, com a simultânea discussão dos dados. Objetiva-se uma discussão sobre o espaço dos saberes locais nas práticas curriculares, salientando a necessidade de convivência entre o local e o universal, o singular e o diverso, pois é importante que o estudante amazonense encontre nos currículos vivenciados na escola a conexão com os elementos identitários que constituem as localidades amazônicas. Somente reformular conteúdos, aumentar ou diminuir disciplinas e ementas, seguir parâmetros, diretrizes, bases curriculares ou modificar metodologias, não darão conta das diferentes realidades que permeiam a escola.

O cotidiano dos alunos deve ser o ponto de partida e de chegada para pensar o currículo. A escola necessita se configurar como espaço no qual as diversas culturas se entrecruzam, de modo que o currículo não seja refém das prescrições e discursos oficiais com propostas únicas e homogêneas para todo um sistema educativo nos mais diversos lugares e localidades. 
Os saberes locais descrevem como um determinado povo dá sentido à sua vida e como se relaciona. Geertz (1997) analisou vários fenômenos culturais de diversos povos para mostrar que os saberes locais se manifestam "através de uma série de formas simbólicas facilmente observáveis, um repertório elaborado de designações" (p. 95). Segundo ele o mundo é um palco onde os atores fazem as suas construções culturais. Essas construções caracterizam a maneira como cada povo vive, convive e representam o universo dos saberes locais: os direitos costumeiros, os mitos, as religiões, as línguas, a agricultura, a arquitetura, a música, as artes, a literatura, artesanato, pintura, os fenômenos socioculturais, a economia, a imaginação, a moral comunidades e funcionam à luz da cultura local, portanto, do saber local.

Usa-se esse termo não se restringindo às formas de saberes nativos, mas estendendo-se para todas as formas de saber que se produzem e se enlaçam nas comunidades. Os saberes locais apreendem as formas como os grupos sociais locais produzem seus mundos, constroem seus discursos, estruturam as regras que norteiam o seu comportamento e como dão significados aos acontecimentos cotidianos. Trata-se de um processo que questiona sobre como as localidades organizam e orientam suas vivencias, situando-se na história e se tornando história.

Os saberes locais, em uma de suas vertentes, fundamentada em Geertz ${ }^{8}$ (1997), propõe uma análise do saber local numa perspectiva sócio-antropológica. Tal posicionamento possibilitou uma reflexão que defende que todo saber científico é social, é local, é total, no sentido de que é produzido pelos sujeitos localizados numa cultura vivida. Essa postura traz um novo horizonte que permite discutir as questões de valor, da ética, da compreensão, dos grupos, do senso comum e do tema sobre saber local. E a escola, hoje, precisa discutir o saber tendo como horizonte não só a universalidade mas também a localidade. Isso por que, segundo Santos (1997) os saberes se constituem como projetos de vida locais, seja para reconstruir a história de um lugar, manter um espaço verde, construir um computador adequado às necessidades locais, fazer baixar a taxa de mortalidade infantil, inventar um novo instrumento musical, erradicar uma doença, etc.

Essa afirmação abre um horizonte para a possibilidade do saber local produzido pelos grupos sociais articular-se ao saber universal, para que as culturas populares não fiquem excluídas na produção e veiculação do conhecimento, é fundamental pensar um currículo que aborde e referencie esses saberes. Para Lopes (1999), os saberes possuem um sentido mais amplo do que o conhecimento, sendo eles independentes das ciências. Por outro lado, toda ciência é um saber, e este está relacionado a uma prática discursiva. É nesse sentido que entendemos o currículo escolar como fruto de um contexto histórico e cultural, o qual implica ações que mobilizam saberes não disciplinares no currículo.

Esteban (2013) salienta que a fragmentação e a hierarquização dos conhecimentos, característica da modernidade, indicam o reconhecimento da existência de diferentes saberes, mas não sua legitimação. Neste estudo, defende-se a ideia de que as relações entre os diferentes saberes devem acontecer na escola sem os hierarquizar, ou seja, sem colocar os saberes locais, do cotidiano em posição inferior em relação aos outros. Eles também devem ser construídos, compartilhados e ressignificados no currículo. Não se trata de negar a importância do conhecimento escolar formal, pois este é relevante na formação dos estudantes, mas não se pode prescindir dos saberes construídos e vivenciados nos cotidianos, pois são saberes ligados à cultura, à vida das pessoas, às crenças, valores, modos de sobrevivência, invenções dos grupos sociais (MARTINS, 2010).

É necessário articular esses saberes, que os mesmos dialoguem no processo de pensar e praticar os currículos escolares, que os currículos sejam espaços para transformações, compartilhamento das diferenças, colaboração mútua e articulação dos diversos conhecimentos, para que não sejam esvaziados de significado. Freire (1996) enfatiza que a escola deve se contrapor ao caráter homogeneizador e monocultural do conhecimento escolar e produzir práticas que legitimem as diferenças culturais e problematizem os saberes diversos que compõem as histórias e vivências dos sujeitos.

O currículo não é algo pronto e acabado, ele é fruto de constantes discussões, tensões e conflitos, os quais abrangem aspectos históricos, políticos, econômicos, sociais e culturais que constituem o contexto educacional, os quais permeiam os diversos e múltiplos saberes que são produzidos nos diferentes contextos escolares, das diversas localidades, que se constroem no chão das escolas, nas experiências docentes e discentes.

\footnotetext{
8 Geertz (1989) pretendeu mostrar a importância das comunidades na modelagem dos saberes locais e na estruturação dos seus discursos e afirma que a interpretação antropológica faz a leitura do que acontece nas comunidades para se compreender como as pessoas estruturam o seu conhecimento. Ele descreveu o modus vivendi de vários povos americanos e africanos.
} 


\section{METODOLOGIA}

A partir de uma abordagem qualitativa e sob uma perspectiva crítica de currículo, a Pesquisa de Campo realizou-se em 01 (uma) escola pública de Ensino Fundamental (1o ao 5o ano) do município de Parintins, localizada no estado do Amazonas. Tal escolha proporcionou um contato direto com os sujeitos, possibilitando uma análise interpretativa dos dados articulada aos estudos bibliográficos sobre o tema.

Os instrumentos utilizados para efetivação da pesquisa de campo foram a entrevista semiestruturada com 04 (quatro) professores que atuavam em turmas de 5o ano do Ensino Fundamental, os quais concordaram em colaborar com o estudo por meio do termo de consentimento e anuência da escola, buscando assim alcançar os objetivos propostos. Juntamente, a observação direta realizada na sala de aula, onde os referidos docentes atuavam.

Deste modo foi possível identificar as problemáticas no campo de investigação do currículo, dialogar com os professores, verificar a práticas curriculares em sala de aula, articulando as ideias teóricas dos autores estudados com a realidade identificada por meio das vozes dos sujeitos colaboradores desta investigação. Ressaltamos que os nomes dos sujeitos usados no decorrer das discussões, são fictícios.

\section{RESULTADOS E DISCUSSÃO}

O currículo não é um elemento inocente e neutro de transmissão desinteressada do conhecimento social, mas produz identidades individuais e sociais particulares. Portanto deve ser pensado e praticado como um processo que discute e interpreta os saberes de nós mesmos, de nossas relações com o outro e com o meio ambiente, permitindo a apropriação do saber escolar que se inscreve em um determinado contexto histórico e cultural.

Dentre as questões que nortearam a entrevista uma delas estava relacionada à compreensão dos sobre os saberes locais. Os professores afirmaram:

Eu acredito que esses saberes são os do dia-a-dia desse aluno, sobre a cidade, suas festas, sua cultura, o boi-bumbá, que é uma festa conhecida em todo mundo, esses conhecimentos são importantes para o aluno. (Professor Lindomar)

Acho que seria as crendices, a culinária, o remédio caseiro, as histórias das nossas avós. É isso que eu penso. (Professora Anita)

No saber local a gente tem que partir desde a linguagem e por todas as manifestações, que até já perdemos muito. Os alimentos, os nossos pegadores de ossos, benzedeiras, as parteiras que ainda atuam e são valorizados mais no interior. As plantas medicinais, esses remédios naturais, da terra são muito úteis, mas estão sendo abandonados. Enfim, muito se perde por não conhecer o que se tem na realidade. (Professor João)

Eu não sei se é bem neste sentido, mas eu entendo também o local muito preso ao regional. Então, os saberes locais eu entendo assim que seja além do conhecimento do aluno próprio, adquirido pelo meio, como aqueles que envolvem aquela região, aquele grupo, aquela comunidade. E são vários né, como aqueles que envolvem a área da literatura, a dança, as lendas, a música. Na parte da ciência tem as plantas medicinais e os elementos da natureza, a ecologia, e os elementos matemáticos que estão presentes na natureza, a ecologia e outros mais. Então tem todo um saber no currículo que deve ser contemplado no contexto escolar. (Professor Lucas)

Pode-se observar nas falas dos professores entrevistados que todos enfatizaram que os saberes locais são os saberes relacionados aos aspectos culturais de uma localidade (que pode ser de uma região, grupo, cidade, comunidade) manifestadas pela culinária, medicina popular, literatura, lendas, mitos, linguagem e festas populares.

De fato, os saberes locais estão ligados à cultura e à vida das pessoas, são a base do meio humano vivido, produzidos e materializados pelas comunidades para sua difusão às gerações vindouras. Tais saberes se oferecem sob a forma de cultura popular ordenada em torno do prazer, do mito, de tabus, de crenças, de diversão, de educação, de rituais e de seu modo de sobrevivência. Nas localidades, eles se referem a habilidades, atitudes, experiências, valores e modos de vida (BASÍLIO, 2006). Por conta disso, fazer uma abordagem sobre os saberes locais é reclamar seu estatuto histórico dentro das culturas, exigindo seu 
reconhecimento. Esses saberes referem-se aos conhecimentos do dia-a-dia do aluno que fazem parte de seu entorno, por isso a importância de valorizar os saberes das benzedeiras, parteiras, pegadores de ossos, como foi enfatizado por um dos entrevistados.

Moreira (1995) destaca a necessidade de educadores que atuem como intelectuais transformadores, críticos, pesquisadores, que dialoguem com os diversos saberes, para que o currículo e o ensino não apaguem as diversas vozes, as experiências e os conhecimentos que os estudantes lançam mão para se identificarem e compreenderem o mundo em que vivem. 0 autor indaga se na escola tem sido permitido e incentivado utilizar e atribuir significados diferentes dos "oficiais"? Tem-se dado espaço à leitura e a produção de textos que se afastem da moldura do discurso dominante? Como evitar que o professor venha a igualar diferenças e deficiências se os saberes identitários de seus alunos não são considerados? (MOREIRA, 1995)

Todavia o que se percebeu durante a observação das práticas docentes é que, em geral, as necessidades dos alunos não estão presentes na organização do trabalho escolar, desde a seleção de conteúdos até as trocas subjetivas entre sujeitos no cotidiano, com manifestações de desejos, vontades, expectativas, conjecturas, ou seja, as interações e socializações. Os professores ainda se limitam a conhecimentos circunscritos às estruturas e modelos estáticos, conceitos técnicos de gramática e matemática, listas de conteúdos sem sentido, textos sem interação com a realidade. Preocupados com as avaliações a nível nacional que darão prêmios à escola que conseguir melhores notas. Desse modo, os diversos saberes que fazem parte da localidade não são trabalhados, e, consequentemente os alunos não se apropriam deles como parte de sua história, de suas vivências. Garcia e Moreira (2003, p. 07) reiteram: "Penso que a discussão sobre o que precisamos ensinar a quem, na escola, sempre demanda novas análises, novos ângulos, novas perspectivas. É uma discussão que precisa sempre se renovar [...]. Fracasso e exclusão continuam a marcar nossa escola" mesmo com todas as politicas, diretrizes e reformulações.

Os professores compreendem os saberes locais como elementos importantes para constituírem os currículos escolares, mas executam em suas práticas fundamentalmente conteúdos referentes à gramática, cálculo, conceitos geográficos, sem relacioná-los nem articulá-los aos saberes que abarcam os problemas, o cotidiano, as aspirações, enfrentamentos, incertezas dos educandos.

Os professores também salientaram que a proposta curricular utilizada na escola construída pela Secretaria Municipal de Educação, não contempla esses saberes da realidade local numa dimensão distinta, singular, a não ser pelos assuntos pontuais nas disciplinas de História e Geografia sobre o estado do Amazonas, o folclore parintinense, as lendas, dentre outros. Há uma parte do currículo estabelecida, reservada e determinado para abordar as temáticas locais, pois nas propostas curriculares, os alunos do 5o ano devem estudar esses conteúdos exclusivamente em Geografia e História do Amazonas.

Mesmo os professores tendo afirmado que trabalham os aspectos referentes aos saberes locais por meio do folclore, das lendas, dos mitos, da história do Amazonas, da literatura, da arte, das datas comemorativas locais, do festival folclórico e que a escola tem buscado trabalhá-los por meio de projetos escolares, o que se percebeu na investigação foi que a abordagem pelos professores às temáticas regionais do Amazonas se restringia a questionários sobre o relevo e clima do Amazonas, cópia de apontamentos e exercícios dos livros didáticos e algumas desenhos livres. Os alunos acabavam repetindo mecanicamente o que os livros diziam sem fazer uma intervenção dinâmica e construtiva.

Entretanto, um currículo que aborde o local cria um espaço de convivência dos saberes local e universal e lança um desafio aos professores no sentido de serem responsáveis pela produção e sistematização do conhecimento. 0 que se pretende e se faz necessário, portanto, é mobilizar essas diferenças locais e não eliminá-las.

Geertz (1997, p. 249) afirma que "[...] a navegação, a jardinagem, a poesia, o direito [...] são artesanatos locais; funcionam à luz do saber local". E o "local", como reitera o autor não se refere somente ao lugar, à época, à categoria e variedade de seus temas, mas também com relação a um complexo de caracterizações relacionadas com ocorrências reais. Indivíduos e grupos vivem suas vidas especificamente por meio de estruturas de significado que são elaboradas, comunicadas, compartilhadas, impostas, modificadas e reproduzidas.

Portanto é necessário valer-se dos diversos saberes dos estudantes, no texto, na música, no desenho, na pesquisa de campo, nas interferências didáticas, na oralidade, nos conteúdos curriculares predispostos nos livros didáticos. Para Morin (1998) é na pluralidade de nossa cultura que se edifica a unidade enquanto forma democrática. 
De acordo com Moreira e Candau (2008), o foco na identidade, no âmbito da educação, revela-se indispensável, em vista de que a escola exerce diante da sociedade funções abrangentes que vão além do simples letramento. Aprender a partir de seu cotidiano sem duvida será o primeiro passo para a valorização do saber local. 0 currículo escolar norteia as práticas pedagógicas, as mudanças articuladas na escola partem da elaboração e ação curricular, construídos a partir das analises contextuais de cada localidade, levando em consideração aspectos culturais, econômicos, sociais, políticos, religiosos, etc.

A escola deve construir o conhecimento (a partir das referências locais, sem prescindir, é claro, das globais), ensinar o aluno a pensar, ser questionador, criativo, ensiná-lo a aprender e, sobretudo, incentiválo para aprender a selecionar e interpretar a informação que se produz. E o currículo, como expressão viva dos elementos culturais destes educandos e educadores, não escapa da presença de manifestações caracterizadas pelas experiências vividas.

Wagley (1988) em seu livro "Comunidade Amazônica” narra de modo estimulante sobre o vínculo dos habitantes com o lugar - base social comunitária -, os laços de família, a união dos moradores, a assistência recíproca entre as pessoas, a residência em comum, a amizade, o "parentesco espiritual", a devoção por um santo particular, os episódios engraçados e os acontecimentos que chegam depressa. Essas situações que são inerentes a quem nasce na beira do rio e vive em contato direto com a história do homem amazônico. Acrescenta que embora a economia, a religião, a política e outros aspectos de uma cultura estejam interligados e forme parte de um sistema geral de cultura de uma comunidade, cada uma destas comunidades é uma manifestação local, que compartilha sua herança cultural. "É nas comunidades que os habitantes de uma região ganham à vida, educam os filhos, levam uma vida familiar, agrupam-se em associações, adoram seus deuses, têm suas superstições e seus tabus e são movidos pelos valores e incentivos de suas determinadas culturas" (p. 44).

Não se quer com isso supervalorizar a cultura que o aluno traz em detrimento da aquisição de outros saberes, mas sim possibilitar um espaço de ressignificação de conhecimentos, de produção de novos saberes, de problematização dos diferentes modos de compreender o mundo. Garcia e Moreira (2003, p. 13) afirmam que "[...] a sala de aula deveria ser um riquíssimo espaço de diferentes saberes que se cruzam, entrecruzam, entram em conflito, produzindo novas possibilidades [...] e aumentado a compreensão que cada um pode ter de si mesmo". Enfatiza que a escola vive afirmando ser transmissora do conhecimento em seu sentido mais amplo ou restrito, mas, na verdade, acaba por trabalhar com fragmentos.

Falando especificamente sobre o município de Parintins e seus saberes culturais, os quais se referem aos conhecimentos, saberes populares e científicos, destrezas, habilidades, aptidões, que as pessoas lançam mão para construir a até "desconstruir" o mundo que faz parte, não se pode admitir passivamente que os espaços escolares continuem sendo um lugar para a memorização de informações descontextualizadas e inertes. É imprescindível o estudante encontrar nos conteúdos escolares, a conexão com os aspectos culturais do seu cotidiano.

Para tanto, o pensar e fazer docentes são relevantes na difusão desses saberes. Muitos professores não se dão conta do quanto é necessário trabalhar os saberes vivenciados no cotidiano dos alunos, é aquilo que Freire e Shör (1986) chamam de criar vínculos entre as "palavras da escola" e as "palavras da realidade". A formação escolar para o mundo da vida implica num currículo que trate contextos e condições reais inerentes às ações cotidianas das pessoas.

Para gerar processos de construção de conhecimentos escolares significativos e socialmente relevantes à vida dos estudantes são necessárias reflexões críticas, desde a formação inicial dos professores, concepções e práticas pedagógicas, valorizando uma visão de escola como instância de produção cultural, sem incorrer no risco de uma "valorização de finalidades acadêmicas", de reduzir o papel da escola a uma mera reprodução de conteúdos prontos e acabados, sem potencialidade para promover a qualidade da vida em sociedade (LOPES, 2007).

\section{CONCLUSÕES}

O currículo faz parte de um sistema cultural múltiplo e amplo que, portanto, é um campo de conflitos e disputa em torno das representações das vozes culturais plurais. Mas podemos, como educadores, responder a essa realidade de modo a trazer os estudantes-sujeitos para o currículo. 0 professor deve reconhecer-se como sujeito de saberes, experiências, indagações e incorporar os educandos também como sujeitos de experiências e saberes. Como acentua Arroyo (2011), trabalhar o ensinar-aprender não sobre matérias distantes, abstratas, mas ampliar e aprofundar as relações entre a diversidade de conhecimentos na relação pedagógica e na construção do currículo. Não nos aceitarmos passivos é um ato consciente e 
esperançoso do fazer educativo, do fazer o currículo, um currículo reorientado à luz dos saberes do contexto amazônico.

Na realização da pesquisa, verificou-se o quanto é preciso mudar, repensar as concepções curriculares para assim gerar práticas mais autônomas, críticas e significativas, contribuindo para que os diversos saberes e culturas sejam reconhecidos e valorizados no cotidiano escolar, desenvolvendo os conteúdos curriculares de modo mais participativo, trazendo para sala de aula os saberes populares da arte, música, saberes tradicionais, religiões diversidade linguística, dentre outros.

Os saberes, identidades amazônicas precisam também ser reconhecidas, compreendidas e compartilhadas por meio de propostas, projetos e ações curriculares, favorecendo a construção de uma sociedade mais democrática e plural, que combata a homogeneização identitária e os discursos em favor de uma globalização e voz "universal".

\section{REFERÊNCIAS}

[1] APPLE, Michael W. A Política do Conhecimento Oficial: faz sentido a ideia de um currículo nacional? In: Moreira, Antônio Flávio Barbosa \& Silva, Tomaz Tadeu da. Currículo, Cultura e Sociedade. 9. ed. São Paulo: Cortez, 2006.

[2] Arroyo, Miguel G. Currículo, território em disputa. Petrópolis, RJ: Vozes, 2011

[3] Basílio, Guilherme. Os saberes Locais e o Novo Currículo do Ensino Básico. Dissertação de Mestrado em Educação pela Pontifícia Universidade Católica de São Paulo em convênio com a Universidade Pedagógica de Moçambique, 2006.

[4] Esteban, Maria Teresa. Encontros e desencontros no cotidiano escolar. Revista Teias, Rio de Janeiro, v. 14, n. 33, p. 168-175, 2013.

[5] Freire, Paulo. Pedagogia da autonomia: saberes necessários à prática educativa. São Paulo: Paz e Terra, 1996. (Coleção Leitura).

[6] ____; Shör, Ira. Medo e ousadia: o cotidiano do professor. Tradução de Adriana Lopez. Rio de Janeiro: Paz e Terra, 1986.

[7] Garcia, Regina leite; Moreira, Antonio Flávio.(orgs). Currículo na contemporaneidade: incertezas e desafios. São Paulo: Cortez, 2003.

[8] Geertz, Clifford. 0 saber local: novos ensaios em antropologia interpretativa. Tradução de Vera Mello Joscelyne. Petrópolis, Vozes, 1997. 366 p.

[9] Ghedin, Evandro, Gonzaga. M.A, Heloisa da S.B (org). Currículo e práticas pedagógicas. Rio de Janeiro: Memvavmem, 2006. 280p.

[10] Lopes, Alice C. Conhecimento escolar: ciência e cotidiano. Rio de Janeiro: EDUERJ, 1999. 236p.

[11] _ _ Currículo e epistemologia. Ijuí: UNIJUÍ, 2007.

[12] Martins, Kézia Simeia . Currículo escolar: ressignificação da prática curricular docente. Manaus: 2010 (Dissertação de Mestrado).

[13] Moreira, Antonio Flávio; Silva, Tomaz Tadeu. Territórios Contestados - o currículo e os novos mapas políticos e culturais. Petrópolis: Vozes, 1995.

[14] Moreira, Antônio Flávio; Candau, Vera Maria. Multiculturalismo: diferenças culturais e práticas pedagógicas. Petrópolis, RJ: Vozes, 2008.

[15] Morin, Edgar. A ecologia das idéias. In: O Método 4 - As Idéias. Porto Alegre/RS: Sulina, 1998.

[16] Santomé, J. T. As culturas negadas e silenciadas no currículo. Silva, T. T. (Org.). Alienígenas na sala de aula. Petrópolis: Vozes, 1995, p. 159-177.

[17] Silva, T. T. da. Documentos de Identidade: uma introdução às teorias do currículo. 3 ed. Belo Horizonte: Autêntica, 2010.

[18] Wagley, Charles. Uma comunidade amazônica. In: Uma comunidade amazônica: estudo do homem nos trópicos. 3. ed. Belo Horizonte: Itatiaia; São Paulo: EDUSP, 1988. p. 43-82. 


\section{Capítulo 11}

\section{Vivências corporais humanescentes: Estratégias}

para reencantar a educação

\section{Tereza Cristina Bernardo da Câmara}

Resumo: Este artigo apresenta, de forma bastante sucinta, o recorte de uma prática pedagógica idealizada e construída por uma professora de Educação Física que desenvolver sua ação à luz do pressuposto da Corporeidade. Esse trabalho vem se configurando como proposta de intervenção em cursos de formação de professores, especialmente licenciaturas, por entender a necessidade pungente de fomentar na Educação práticas sensíveis e provocativas, em prol de um mundo mais amoroso e feliz. A Pedagogia Vivencial Humanescente, que tem as Vivências Corporais Humanescentes como lastro metodológico, se apresenta como um dos caminhos que pode ser trilhado nesse processo. A necessidade de reencantar a educação é fato facilmente observado para quem se debruça a investiga-la. As provocações externas são importantes, mas é de dentro de cada ser envolvido amorosamente com essa causa que poderá (res)surgir esse encantamento. 


\section{ADENTRANDO NO MUNDO ENCANTADO DA FORMAÇÃO DOCENTE: UMA INTRODUÇÃO AMOROSA}

Do amor, a gente não sabe da missa a metade, e é por falta dele que a ciência se afastou tanto dos homens.

João Batista Freire

Ser humano, Ser? Humano? Existir. Conhecer. Conhecer-se. Revelar. Revelar-se. Eu sou, tu és, ele é. Nós somos. Humanos. Razão. Emoção. Pensar. Sentir. Formar professores numa perspectiva Humanescente. Desafio posto, desafio aceito. Construir. Agir. Construir, em um cenário de formação docente, uma prática a ser vivida, sentida, refletida para favorecer o desenvolvimento integral do ser. Contemplar suas multidimensionalidade no processo formativo institucionalizado.

Pensada numa perspectiva transdisciplinar, o componente curricular, Corporeidade e Educação, inicialmente ofertada no Curso de licenciatura em Pedagogia, com proposta de ampliação para as demais licenciaturas oferecidas pelo Instituto Kennedy, em Natal/RN, apresenta como objetivo geral compreender a educação na perspectiva transdisciplinar, tendo como foco irradiante a corporeidade. Apresenta ainda como objetivos específicos vivenciar situações pedagogicamente construídas nas quais serão provocados a sentipensar para reencantar a educação e entender a corporeidade na perspectiva de uma formação humanescente.

Trazer a dimensão espiritual do ser para o processo de formação docente foi fruto de inquietações ao identificar a supremacia e quase exclusividade do aspecto cognitivo nesse processo. A Pedagogia Vivencial, alimentada pela ciência dos sentimentos, foi o caminho escolhido para experimentar a "construção amorosa do saber" (Byington, 2003) e a corporeidade o "foco irradiante primeiro e principal" (Assmann, 1998), o que significa dizer que a vida e as vivências seriam trazidas para o processo educativo. Era a construção de uma pedagogia para pedagogizar a vida, a Pedagogia Vivencial Humanescente.

Nesse cenário acadêmico de formação no qual o sensível e o inteligível são companheiros, registros sistemáticos são realizados e sentimentos e pensamentos ganham status de favorecedores de autoconhecimento e de avaliação do vivido. O Diário do Sentipensar é espaço legítimo para traduzir a riqueza do sentido e refletido a cada encontro.

Oportunizar vivências na perspectiva transdisciplinar da Pedagogia Vivencial Humanescente, é entender o conhecimento como complexo, assim como o é o ser que aprende, é uma ousadia epistemológica, metodológica e ontológica que tem possibilitado descortinar a formação também como espaço de amor e de alegria.

\subsection{REENCANTAR A EDUCAÇÃO NA PERSPECTIVA DA FORMAÇÃO HUMANESCENTE}

Hoje, educar significa defender vidas.

Hugo Assmann

Reencantar a educação! Eis o desafio posto e que mobiliza os estudos e a ação docente desta pesquisadora. É premente a necessidade de promover no espaço formativo o encantamento, oportunizar vivências reflexivas que estimulem e envolvam os discentes, futuros pedagogos, no mundo encantado da educação. Eles precisam entrar pela porta da frente, no tapete vermelho da glória.

O cotidiano escolar atual tende a reproduzir uma sociedade sectária, discriminatória e excludente como o é, de maneira preponderante, a nossa. É por crê que o mundo tem sede de luz na forma de amor e alegria, que uma prática de ensino preocupada com essa necessidade, além de discuti-las, se descortina, no intuito de preparar os futuros educadores para, através de seu fazer, intervir na contramão do presente quadro.

Nesse sentido Assmann (1998, p. 34) considera que "Nos docentes deve tornar-se visível o gozo de estar colaborando com essa coisa estupenda que é possibilitar e incrementar - na esfera sócio-cultural, que se reflete diretamente na esfera biológica - a união profunda entre processos vitais e processos de conhecimento." Vida e conhecimento imbrincados na existência humana. 
Desenvolver uma formação humanescente, significa criar condições para que os estudantes expandam sua essência humana irradiando luminosidade, o que beneficiará outros seres, a natureza, a sociedade e o planeta (CAVALCANTI, 2006). Perceber-se como parte integrante de uma grande teia na qual tudo está interconectado é necessário para que eles sintam a relevância do seu papel social e a abrangência que pode ter a sua atuação como educadores.

Desse modo as emoções vão, junto com as demais dimensões da existência humana, está presente no processo formativo e o Sentipensar, termo criado por Saturnino de La Torre ${ }^{9}$ é refletido e vivido no Componente Corporeidade e Educação. Sentir, pensar... sentir e pensar o brincar e o criar. Sentir o pensar e pensar sobre o sentir é considerar a sensibilidade nesse processo. É entender e respeitar a complexidade do ser, abrindo espaço para aquele que ri e chora, tem medo, sente prazer e ama. Prazer em aprender, aprender a viver, ter prazer em viver.

Sentipensar e agir formam o bi/trinômio-chave na experiência que relatamos. Sentipensar a ação, na ação, sentipensar a reflexão sobre a ação. Essas são proposições adotadas a partir de si e sobre si para sentipensar o outro, com o outro, os outros, as coisas e o seu entorno.

Sensibilidade! Grande fome do mundo atual. Sensibilizemos nossos educadores para reencantar e transformar a educação! Professores sensíveis, amorosos, que se envolvem integralmente com o saber, com o ser, com o conviver e o fazer, brincando, criando, sentindo e pensando, numa formação humanescente.

A Formação de Professores como temática instigadora, neste momento histórico da educação nacional, nos leva a refletir sobre as seguintes questões: que professores queremos formar? Para atuar em qual contexto educacional? Ou, de outro modo, que educação queremos construir, redimensionando a que hoje se apresenta? Nesse sentido, romper com a fragmentação Vida e Educação é condição primordial, na perspectiva da experiência aqui apresentada. Trazer vida para a educação, reencantá-la, é o que almejamos.

Desse modo concordamos com Moraes (2004, p.3) quando afirma:

necessitamos mais do que nunca, de um novo modelo educacional que, além de colaborar para a formação do ser, também reconheça a aprendizagem como um processo complexo em permanente construção, que depende das ações e das reações daqueles que conhece, que depende do que acontece em sua corporeidade, das mudanças estruturais que ocorrem na organização autopoiética, das influências múltiplas entre o indivíduo e o meio onde está inserido.(...) que colabore para a formação integral do ser aprendiz, que seja capaz de aproximar a educação da vida e trazer um pouco mais de vida para dentro de nossas salas de aula.

$\mathrm{Na}$ Educação que estamos a construir, aprendizagem não pode ser confundida com transmissão de informações, mecânica, distantes da realidade vivida pelos estudantes, sem sentido e significado. Mero engodo que deforma o verdadeiro sentido de educar para a vida.

\subsection{VIVÊNCIAS CORPORAIS HUMANESCENTES: UM DIÁLOGO COM O AMOR E A ALEGRIA}

O sujeito da educação é o corpo

Porque é nele que está à vida. É o corpo que quer aprender

Para poder viver.

Rubem Alves

\footnotetext{
${ }^{9}$ Processo mediante o qual colocamos para trabalhar conjuntamente o pensamento e o sentimento (...), é a fusão de duas formas de interpretar a realidade, a partir da reflexão e do impacto emocional, até convergir num mesmo ato de conhecimento a ação de sentir e pensar. (La Torre, 2001, p.1)
} 
Vivenciar, sentir na pele, vibrar, dá sentido ao vivido. A prática construída e que é referência para este estudo considera quem é o sujeito que se forma. 0 que ele sente, pensa, se ele cria, brinca, ama, expande sua essência, autotranscende.

0 aprendizado precisa ter sentido, fazer sentido. A "Fonte dos Saberes da Vida" foi uma metáfora criada (CÂMARA, 2005) para representar as Vivências Corporais Humanescentes. Ela é constituída de quatro pilares, que representam os saberes apontados no Relatório Delors e por esses pilares jorra a água que simboliza o entrelaçamento dos Saberes da Corporeidade, reflexividade, sensibilidade, ludicidade e criatividade. Nela, os estudantes em formação banham-se.

As Vivências Corporais Humanescentes sensibilizam quem tem seus sentidos despertados e estimulados para o vivido. A reflexão sobre a vivência, sobre o que sentiu nos momentos de encontro consigo mesmo e com o outro, é registrado no Diário do Sentipensar.

O Diário se torna um espaço no qual os estudantes se revelam nos seus escritos não apenas em relação ao que viveram de maneira objetiva, concreta, mas também a sua subjetividade, eles não mais são obrigados, "a esconder seus sonhos, suas intuições e suas emoções, em suma, esconder sua alma". (BYINGTON, 1995, p. 49).

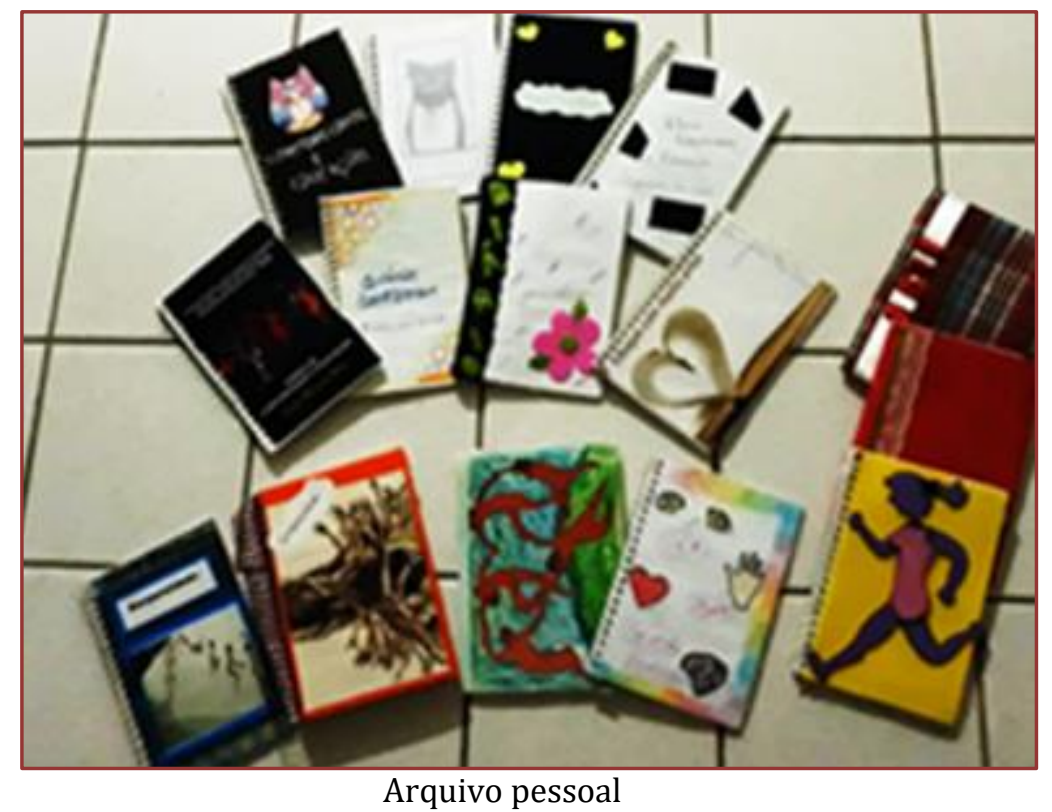

Assim se coloca uma das escritoras do Diário do Sentipensar acerca da sua experiência. "Disciplinas como Corporeidade e Educação são de grande importância, pois nos auxilia no modo de expressar nossas emoções e sentimentos, de entender as mensagens que o nosso corpo transmite e de enxergar o outro com um olhar mais humano". Enquanto outra considera que "A disciplina Corporeidade para mim veio como uma proposta inovadora de reencantar a educação e transcendeu todas as minhas expectativas, me conduzindo a viver a verdadeira espiritualidade da pedagogia[...]".

É desafiador usar a imaginação para promover o envolvimento para incorporação dos discursos, despertar a curiosidade, o intelecto e as emoções dos educandos.

Vivências Corporais Humanescentes fazem parte das estratégias adotadas para provocar o sentipensar nesse percurso de formação. Nessa perspectiva, elas sensibilizam estudantes em formação que tem seus sentidos despertados para a vida. Refletir sobre a vivência, sobre o que sentiu ao vivenciar momentos de encontro consigo mesmo e com o outro reflete o Sentipensar.

Foi trazido para este artigo um recorte do trabalho desenvolvido e apenas uma, das dez vivências realizadas em Corporeidade e Educação, ilustrará esta reflexão. 0 primeiro encontro, cuja Vivência Corporal Humanescente foi o Jogo dos Sentidos, será aqui tratado como espaço provocador de sentimentos e pensamentos. Ao iniciar a aula os estudantes foram convidados a dirigirem-se para um local especialmente preparado para o momento. 
Vale salientar que após a provocação inicial de que podiam fazer tudo que sentissem vontade no espaço de aula menos falar, os estudantes apresentaram desconforto e não ficaram a vontade, não se soltaram, pareciam 'presos'. A postura corporal, com as mãos para trás, revela o constrangimento ao lidar com um espaço de aula diferente, que foge do convencional e os provoca a revelar-se.

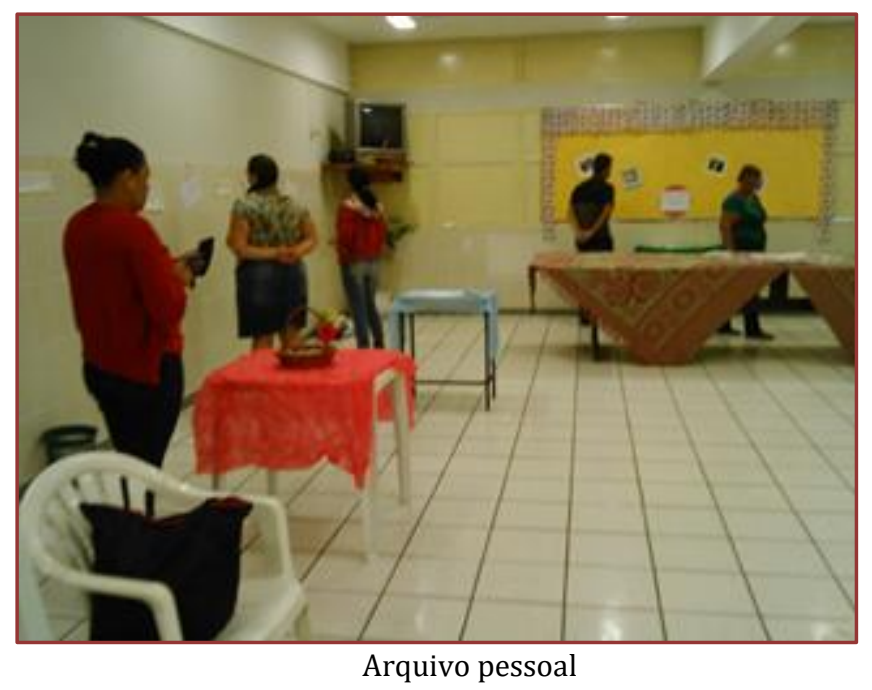

É possível encontrar, nas falas trazidas pelos Diários do Sentipensar, a reflexão que os estudantes fazem acerca do que as vivências provocaram. O primeiro encontro é impactante e isso é expresso por um número significativo deles, como podemos identificar.

A primeira aula de corporeidade foi inesquecível para mim e acredito que para meus colegas também, foi preparada, planejada com tanto carinho (...) nos sentimos acarinhadas com cada detalhe, ali foi explorado cada sentido do nosso corpo (...) foi tudo pensado com muito carinho e amor. É a prova do que é necessário para reencantar a educação, diversificar, fazer com amor, humildade e entusiasmo. Vou levar, com certeza, para sala de aula o que aprendi (...) pois acredito que devemos manter acesa a chama do entusiasmo e do prazer de ensinar e aprender, para tornar a escola um lugar gostoso.

Outra estudante escreveu: "finalmente descobri de onde surgia aquele cheiro gostoso[...] os olhos se deleitavam com a beleza de tudo[...] uma música agradável[...] estou encantada, admirada e curiosa para saber o que está por vir".

A expectativa pelo que virá no próximo encontro é manifestada e o prazer em usufruir de aulas dessa natureza é destacado aqui por uma estudante que afirma que, "no corre-corre da vida não damos grande importância ao está em nosso redor. Passamos despercebido a um canto de pássaro, até mesmo um amigo que precisa que você o escute com carinho. Observei também que é no silêncio que 'vemos' com o pensamento e não apenas com os olhos".

Os depoimentos coletados ao longo deste percurso de formação confirmam o que defende Moraes (2003, p. 66) quando afirma que “[...] para reencantar a educação é preciso transformar a qualidade das experiências de aprendizagem, fazer com que elas deixem de conspirar contra a inteireza humana”. 
A compreensão acerca do vivido e a necessidade de ter acesso a vivências que fujam do modelo convencional de formação docente é reconhecidamente importante para os estudantes, como ilustra esse recorte, “

no início fiquei um pouco confusa, não tinha muita noção, mas com o passar das aulas, com as vivências corporais e as discussões, foram clareando. [...] Achei bacana e aprendi muita coisa boa, uma delas é que o professor foi acostumado a pensar a agir de acordo com o paradigma cartesiano, baseado no raciocínio lógico, deixando de lado suas emoções, a intuição, a criatividade, a capacidade de ousar soluções diferentes.

Podemos afirmar, portanto, que elementos da subjetividade do ser são estimulados pelas Vivências Corporais Humanescentes e pela leituras discussão e de textos e que as mesmas vêm cumprindo seu papel enquanto atividades favorecedoras do autoconhecimento, que valorizam a sensibilidade, as emoções, os sentimentos, os afetos.

\section{ALGUMAS CONSIDERAÇõES}

Precisamos de uma Educação capaz de nos inspirar o encantamento para a dimensão mágica e misteriosa da existência. De coadjuvante a protagonista $d a$ nossa própria realidade.

Wallace Lima

Diante do que estamos a construir como professora-pesquisadora é possível considerar que necessário se faz trazer a vida do educando para o centro do processo educativo, aprender com ela, a partir dela e para ela, esse é o sentido da Pedagogia Vivencial Humanescente.

Nesse contexto as Vivências Corporais Humanescentes são atividades que favorecem a esses estudantes, uma formação que os permita ser professores que sentem e pensam; brincam e criam; que entendem e respeitam a complexidade do ser. Seres sensíveis, capazes de romper com a fragmentação Vida e Educação; que tragam vida para a educação, que a reencante.

Urge a necessidade de uma educação que oportunize um conhecimento que articule, na pessoa que aprende, o encontro entre o que está fora e o que está dentro dela, que o amor e a alegria seja resultado desse encontro para a construção de uma vida e de uma sociedade diferente da que hoje se apresenta e na qual intervimos.

\section{REFERÊNCIAS}

[1] Assmann, Hugo. Reencantar a educação. In: Reencantar a educação: rumo à sociedade aprendente. 3 . ed. Petrópolis: Vozes, 1998. p. 22-34

[2] Byington, C. A. B. A construção amorosa do saber: o fundamento e a finalidade da pedagogia simbólica Junguiana . São Paulo: Religare, 2003.

[3] Câmara, Tereza C. Corporeidade e humanescência na fonte dos saberes da Vida: a formação de professores que valoriza o ser. 2005. 146 f. Dissertação (Mestrado em Educação) - Universidade Federal do Rio Grande do Norte, Natal, 2005.

[4] Cavalcanti, Kátia B. Para abraçar a humanescência na pedagogia vivencial. In: Endipe - Encontro Nacional de Didática e Prática de Ensino, 12., 2006, Recife. Anais... Recife, 2006.

[5] Lima, Wallace. Pernambuco avança com um novo modelo de universidade: Medicina Quântica será aporte para novo olhar sobre cura. In: <http://www.diariodepernambuco.com.br Recife, 2010.

[6] Moraes, Maria Cândida. Educar na Biologia do Amor e da Solidariedade. Petrópolis: Vozes, 2003.

[7] Moraes, Maria C. Pensamento eco-sistêmico: educação, aprendizagem e cidadania no século XXI. Petrópolis: Vozes, 2004. 


\section{Capítulo 12}

Bullying escolar: Suas consequências e a atuação do serviço social para minimizar essa prática

\section{Maria Goretti Rodrigues de S. Oliveira}

Dalnes Cristine de F. Godim

Maria Aparecida Pereira

Nájila Brandão da Silva

Maria de Fátima Leite Gomes

Resumo: Este artigo resulta de um levantamento documental, sobre a prática do bullying na Escola Municipal Nazinha Barbosa da Franca, localizada no Bairro de Manaíra, em João Pessoa-PB. 0 mesmo decorre da necessidade de um conhecimento mais aprofundado acerca dessa problemática. Tem como objetivo colaborar com o processo de inclusão escolar, reconduzindo alunos vítimas desse "tratamento", à sala de aula, partindo do pressuposto que tanto vítimas quanto agressores necessitam de ajuda. A metodologia utilizada se fundamenta no levantamento exploratório, de abordagem quali-quantitativa. Na realização do levantamento documental foram analisados os relatos do livro de ocorrência das especialistas, onde são registrados os fatos que ocorrem na escola com o alunado, nos quais foram encontrados relatos de alunos dos $3^{\circ}$ e $4^{\circ} \stackrel{\circ}{a}$ anos, do Ensino Fundamental I, bem como, dos educadores dos referidos anos escolares, através do qual se evidenciou a necessidade de realizar um trabalho socioeducativo, a fim de buscar-se coibir essa prática, de modo que, todos compreendam os danos que esse fenômeno social proporciona às vítimas. Desse modo, verifica-se através do levantamento obtido com os alunos envolvidos, que $83,33 \%$ dos alunos sabem o que é bullying; $16,66 \%$ não sabem; 73,33\% afirmaram ter praticado bullying; $73,33 \%$ foram vítimas; $26,66 \%$ não cometeram nem foram vítimas. Dos alunos que foram vítimas 56,66\% comunicaram o fato a alguém e $16,66 \%$ não comunicaram. Quanto aos tipos 75\% foram apelidar, 18\% bater, 7\% xingar. Diante desses dados, espera-se em cooperação com alunos, pais, professores e toda a equipe multidisciplinar, que participam desse processo, que cumpram seu papel para reduzir tamanha violência que prejudica crianças, adolescentes e jovens, nesse universo escolar.

Palavras-Chave: Bullying, Serviço Social, Inclusão Escolar. 


\section{INTRODUÇÃO}

O presente artigo resulta de pesquisas e análises sobre a prática do bullying na Escola Municipal Nazinha Barbosa da Franca, localizada no Bairro de Manaíra, em João Pessoa-PB, por decorrência da realização, na referida escola, de um projeto de extensão orientado pela Prof. ${ }^{a}$. Dr ${ }^{a} M^{a}$ a de Fátima Leite Gomes, vinculado ao PROBEX( Programa de Bolsa de Extensão da Universidade Federal da Paraíba). Este estudo surgiu da necessidade de conhecer e compreender essa problemática, cujos objetivos são: estimular a inclusão escolar e analisar a prática do bullying, suas consequências e sequelas, no intuito de combater a violência escolar, bem como colaborar com uma cultura de respeito às diferenças, além de discutir a atuação do assistente social para minimizar essa violência.

Assim, registra-se que na territorialidade da cidade de João Pessoa-PB, a promulgação da Lei 11.385, de 16 de Janeiro de 2008, que cria o Serviço Social Escolar nas escolas públicas do Município, "com o objetivo de prestar assistência social aos alunos e seus familiares, a fim de minimizar as diversas expressões da questão social, no âmbito das drogas, doenças sexualmente transmissíveis, violência, o bullying, entre outros", como determina a Lei 11.385, no Artํ․ $3^{\text {o }}$ e seus incisos I, II, III, e IV, que tratam das atividades a serem exercidas pelo profissional de serviço social.

Nesse sentido, pretende-se explanar ao longo deste, a realidade do bullying na escola referenciada e o papel que ocupa o Serviço Social neste contexto, entre os alunos matriculados no 3ㅇ e 4o ano, do Fundamental I. Embora não seja um fato social recente, o bullying tornou-se mais evidente na década de 1990, em decorrência dos casos ocorridos a nível internacional que resultaram em mortes.

\section{PROCEDIMENTOS METODOLÓGICOS}

A metodologia utilizada se fundamenta no levantamento exploratório, que consistiu na busca por material para uma compreensão do tema em questão, visando conhecer as formas de ação e os tipos de bullying que ocorrem na escola citada anteriormente, assim como, as intervenções realizadas pelos Assistentes Sociais.

A abordagem utilizada foi quali-quantitativa, tendo em vista o intento em compreender os fatos que levam a ocorrência desse fenômeno social, mediante também da análise documental, além de um referencial bibliográfico que dá suporte teórico ao levantamento. A análise dos dados ocorreu com base na sistematização destes, à luz da teoria crítica.

Esse levantamento contribui na unidade escolar referenciada para o estímulo da conscientização sobre bullying, que como toda e qualquer forma de violência tem as suas consequências, tanto para o agressor quanto para a vítima. No caso do agressor, o mesmo está passivo a diversas sanções, uma vez que a prática do bullying infringe a Constituição Federal de 1988 em seu Arto $\underline{\text { 10 }}$, incisos II e III, uma vez que fere o direito à cidadania e dignidade da pessoa humana, tanto quanto o Art. 5o e os incisos II, III, X, XV. Os quais resguardam o cidadão de não ser forçado a praticar o que não deseja, bem como proíbe a tortura entre outros atos que ferem a dignidade humana.

Na pesquisa bibliográfica diversos conceitos e definições para bullying foram encontrados, cujo termo bully é de origem inglesa, e significa valentão, tirano, e pode ser conceituado de forma clara. Para Teixeira (2011, apud SOARES, 2013):

[...] o bullying é conceituado como "comportamento agressivo entre estudantes (sic). São atos de agressão física, verbal ou moral ou psicológica que ocorrem de modo repetitivo, sem motivação evidente, por um ou vários estudantes contra outro indivíduo, em uma relação desigual de poder, normalmente dentro da escola.

Desse modo, percebe-se ser um fato que acontece de diversas formas, mas que geralmente inicia-se com agressão verbal e em ato contínuo, podendo passar a agressão física ou não. 
De acordo com a ABRAPIA ( Associação Brasileira Multiprofissional de Proteção a Infância e a Adolescência) o bullying:

[...] compreende todas as formas de atitudes agressivas, intencionais e repetidas, que ocorrem sem motivação evidente, adotadas por um ou mais estudantes contra outro(s), causando dor e angústia, e executadas dentro de uma relação desigual de poder. Portanto, os atos repetidos entre iguais (estudantes) e o desequilíbrio de poder são as características essenciais, que tornam possível a intimidação da vítima.

\subsection{RESULTADOS E DISCUSSÕES}

No levantamento realizado, buscou-se identificar os alunos, de ambos os sexos, dos 3ำ e $4^{\circ}$ anos, que estiveram envolvidos em situação de bullying, bem como os professores destes. Conforme os relatos documentais, do universo de 30 alunos, ao ser chamado à sala dos especialistas, por ocasião de envolvimento em situação de bullying, 25 alunos sabem o que é bullying, e 05 afirmaram que não sabiam. De forma que, obteve-se os seguintes dados como apontam os gráficos abaixo.

Gráfico 1: Alunos que praticaram /não praticaram bullying

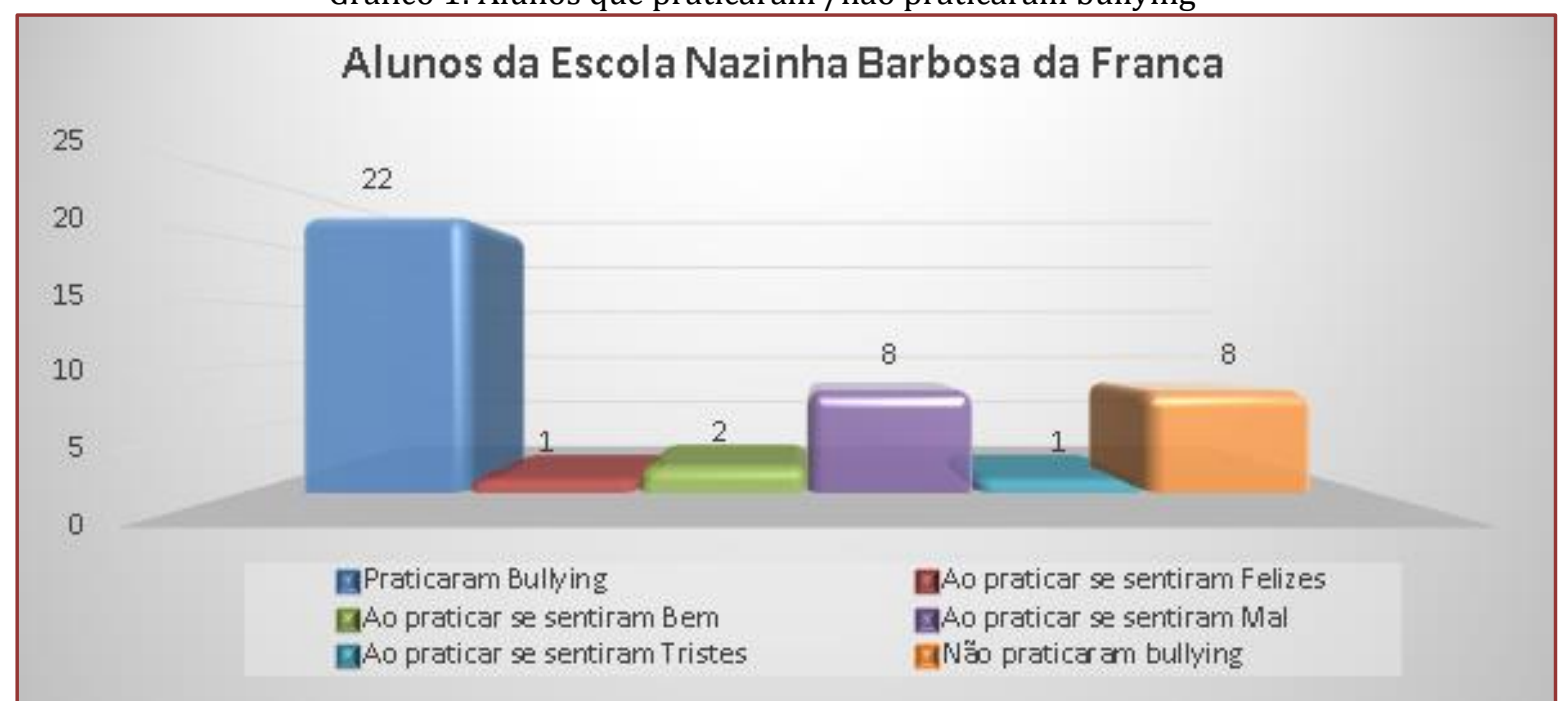

Fonte: Adaptado conforme relatório das Especialistas da EMNBF.2015

Gráfico 2 : Alunos Vítimas de Bullying

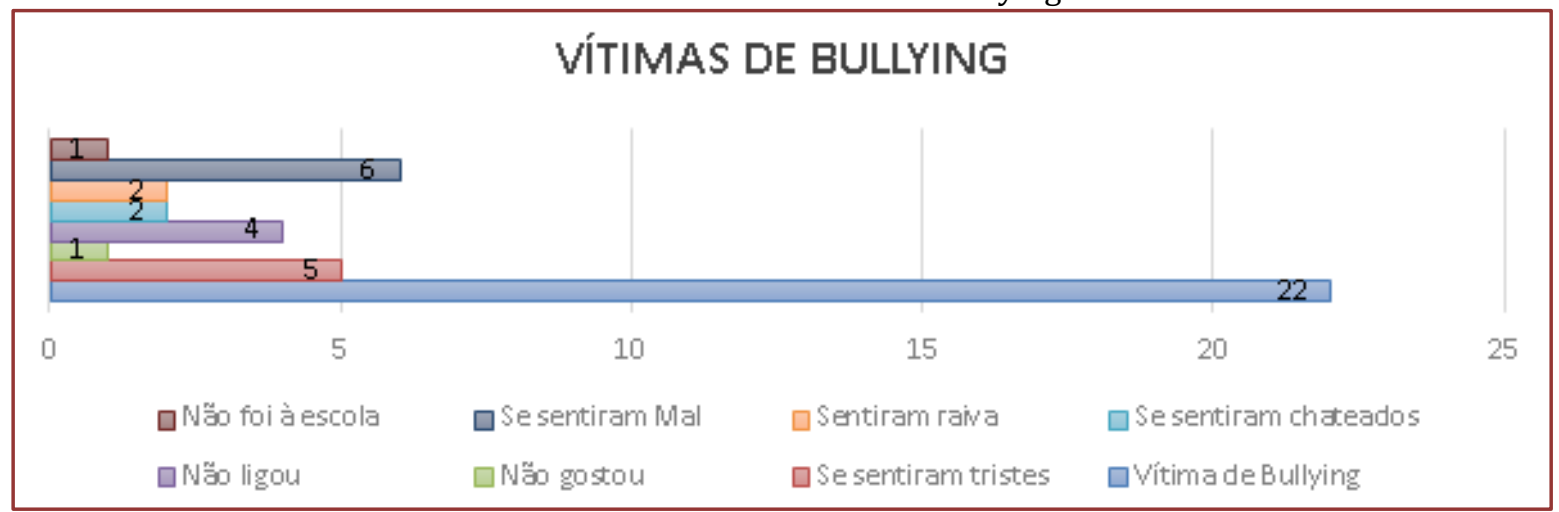

Fonte: Adaptado conforme relatório das Especialistas da EMNBF.2015

Percebem-se mediante os dados do gráfico 1 e 2, que o número de alunos praticantes é igual ao número de vítimas, o que corrobora com as justificativas informadas pelos educadores acerca dos motivos alegados pelos os (as) alunos (as) para praticaram bullying, os quais revelaram, que: "praticaram para revidar", e/ou "estavam brincando". 
No que tange ao que os praticantes sentiram após a agressão, estes em sua maioria afirmaram sentir-se mal após a prática, um deles até afirmou que só se sentiu mal por ter praticado quando ele próprio foi à vítima.

Gráfico 3: Tipos de bullying praticados

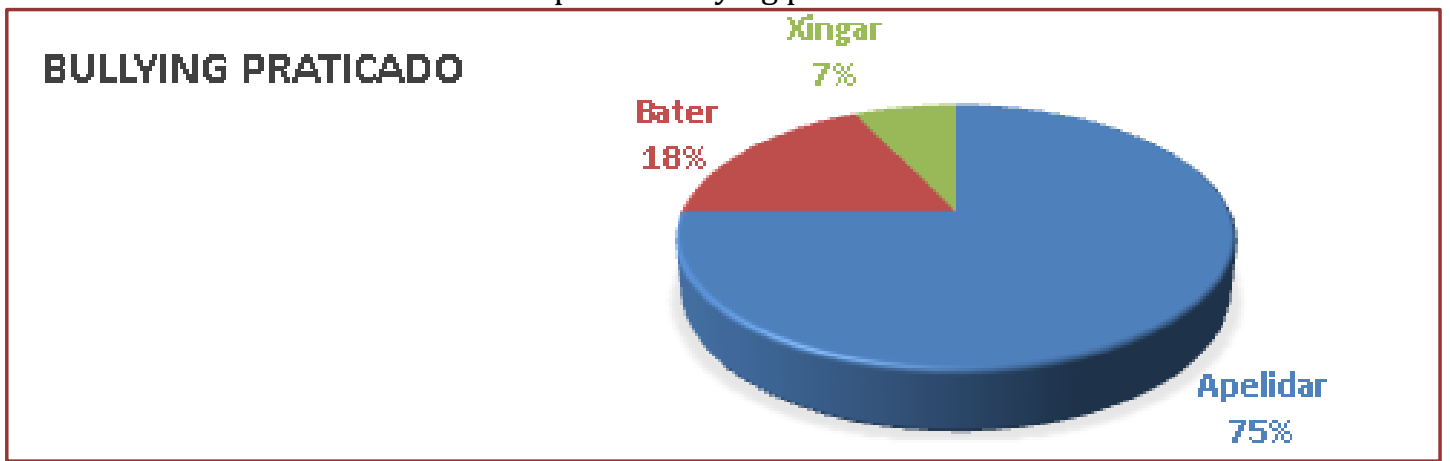

Fonte: Adaptado conforme relatório das Especialistas da EMNBF.2015

Os tipos de bullying identificados, como demonstra o gráfico 3, de acordo com os professores, nos relatos encontrados, estão relacionados à cor (visto que muitos relataram terem sido chamados de "macaco"); aos aspectos físicos, à sexualidade e a higiene pessoal. Nota-se, segundo estes, que há um grau de descuido na higiene pessoal das crianças.

O gráfico que segue informa o número de vítimas que buscaram ajuda comunicando o fato aos pais e ou amigos.

Gráfico 4: Alunos que foram vítimas e buscaram ajuda

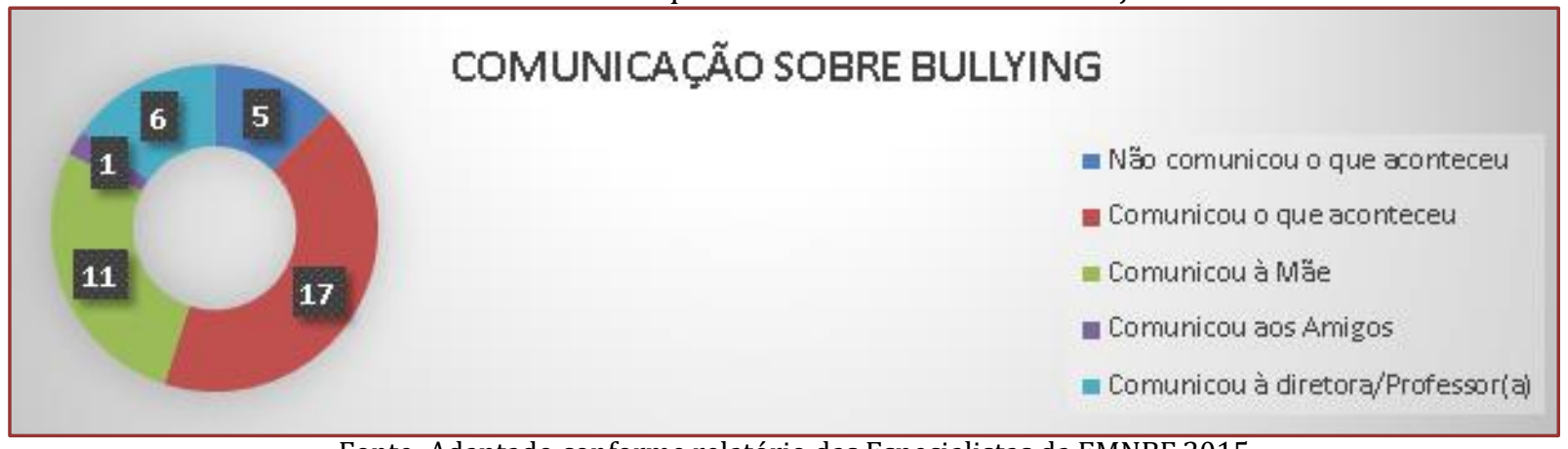

Fonte: Adaptado conforme relatório das Especialistas da EMNBF.2015

O gráfico acima demonstra que a maioria das vítimas não se manteve calada, pois comunicaram o fato a alguém, porém, vê-se que nenhum aluno afirmou ter buscado o Serviço Social. Por sua vez, a Assistente Social quando questionada sobre as intervenções realizadas ao descobrir um caso, declarou que: "buscam conversar com os pais e alunos"; "buscam compreender o sofrimento da vítima";" buscam orientar a família e o vitimado"; "buscam à colaboração de outros profissionais".

Desse modo, torna-se evidente o quanto se faz necessário abordar essa problemática, na escola. 0 Código Civil Brasileiro, Art. 932. Inciso I trata da responsabilidade dos pais para com os filhos menores que estiverem em sua companhia, e o Art. 928, estabelece que no caso do menor de idade, o responsável arcará com o dano causado por aquele por quem é responsável. Assim, Soares (3013. p.54) salienta a importância da família para o combate ao bullying, pois, esta deve "estar atenta à formação afetiva, psicológica, humanista, cultural e social de suas crianças para que sua inserção na sociedade seja completa, sem conflitos permeados por preconceitos ou por egocentrismos que resultem em violências físicas ou morais a terceiros". Ainda conforme Soares (2013) evidencia-se também que a falta de limite "[...] imprime na psique de uma criança que tudo ela pode e que não há limitações entre o direito dela e de outra pessoa. Ou seja, resultará em uma criança egoísta e sem valores morais".

No entanto, esse limite deve ser dosado, visto que em excesso, ou mal colocado, usando de agressividade para impor esse limite, levará a criança a precisar se auto afirmar, por sentir-se intensamente tolhida, 
cerceada. Tratando-se, assim, de um agressor cuja influência é a família, pois, como afirma Soares (2013) "[...] a criança crescerá com a informação de que a agressividade e a intolerância são formas adequadas de resolução de um problema e podem se tornar praticantes de bullying como forma de autoafirmação".

Soares (2013, p. 67) resume da seguinte forma os deveres dos pais e da escola:

Com todos estes fundamentos legais é mais do que correto afirmar que há um dever dos pais, das instituições de ensino tanto públicas como privadas (decorrente da responsabilidade civil objetiva) de cuidado para com a integridade física e psicológica de seus respectivos filhos e alunos enquanto estes estiverem sob suas tutelas.

Na concepção de Soares (2013, p.74), “[...] o ambiente familiar sem estrutura educacional somada a uma instituição de ensino despreparada contribui para a ocorrência da violência escolar conhecida como bullying".

A Associação Brasileira Multiprofissional de Proteção a Infância e a Adolescência. evidencia que é um acontecimento susceptível a qualquer escola independente de ser pública ou privada, abrange qualquer série e salienta ainda, que "[...] as escolas que não admitem que a ocorrência de BULLYING entre seus alunos ou desconhecem o problema, ou se negam a enfrentá-lo". Isso demonstra a necessidade de atenção aos alunos no sentido de identificar quando e como o fato ocorre, quem são as vítimas em potencial, o que real realmente é o bullying.

Fante; Benavente, (2004; 2005 apud TOGNETTA, 2005.p.6), afirmam que:

(...) atos de bullying se referem aos danos físicos, morais e materiais, sofridos por alguém ou por um grupo: insultos, apelidos cruéis, gozações que magoam profundamente, ameaças que ocorrem nos recreios ou na saída, acusações injustas, agressões individuais ou em grupos.

Essa violência, Soares (2013, p.14) a denominou de "mal social”, definindo-a como “(..) uma das formas mais traiçoeiras e letais de violência, que só depois de inúmeras demonstrações de sua brutalidade começou a ser estudada e evitada".

No entanto, nem todo xingamento é bullying, visto que, para ser considerado como tal, é preciso apresentar suas características que segundo Olwens (1993, apud CUBAS, 2006, p.177) são três: "Comportamento agressivo ou de uma ofensa intencional; ocorre repetidamente e durante muito tempo; ocorre em relações interpessoais caracterizadas por um desequilíbrio de poder".

0 bullying também consiste em fazer com que a vítima faça o que ela não quer ameaçando-a para seguir as ordens como exemplifica Torgnetta $(2005$, p.6): 'Se você não me der essa caneta eu vou falar que você é bicha, eu vou falar que você pegou de alguém... vou (sic) falar alguma coisa da sua mãe ou do seu pai...", ou ainda, do tipo: "Você tem que pagar o meu lanche hoje porque senão você apanha...'.

Olweus (1993 apud CUBAS 2005, p. 181-182) aponta as principais características que portam agressores e vítimas. Em relação às vítimas essas características foram classificadas como gerais, nas quais as vítimas são fisicamente mais fracas, ansiosas, com baixa autoestima, quietas, relacionam-se melhor com adultos do que com pessoas de sua idade. Nos sinais primários:

[...] as vítimas são repetidamente importunadas de forma vexatória são chamadas por apelidos depreciativos; são ridicularizadas e ameaçadas; são motivos de piadas (não amigáveis); são humilhadas, agredidas, têm seus pertences roubados ou estragados. Apresentam machucados como arranhões e cortes, roupas rasgadas, aos quais não é possível dar uma explicação natural.

Por sua vez, nos sinais secundários descritos por Olweus, as vítimas "são excluídas de grupos, procuram adultos para conversar, são depressivas, não levam amigos para estudar em casa". Apresentam ainda outros sinais: "Recusam ir a festas, relutam em ir à escola, perdem o apetite, dores de cabeça ou de estômago, mudam de hábitos escolhem caminhos não usuais para a escola, são tristes ou demonstram mudanças repentinas de humor e passam a pedir mais dinheiro a seus pais". 
Olweus (1993 apud CUBAS 2005, p.187) ainda afirma que:

[...] os agressores normalmente importunam outros alunos de maneira desagradável, insultam, agridem, ridicularizam e estragam os pertences de seus colegas. Podem apresentar esse comportamento diante de qualquer aluno, mas seus alvos preferenciais são os alunos mais fracos. Muitos induzem outros colegas a fazerem o "trabalho sujo"(...). Podem também ser fisicamente mais fortes que seus colegas e ter bom desempenho nas atividades físicas. Têm forte necessidade de dominar os outros, ficam irritados com facilidade, são intolerantes e têm dificuldades para obedecer às regras. São desafiadores (...). São considerados valentões e durões, têm autoestima e, com frequência, são apoiados mesmo que por um grupo pequeno de colegas(sic).

Diante disso, é preciso que ocorra a intervenção, visto que, a criança ou adolescente que infringe uma lei e não se faz intervenções, os mesmos crescem com a impunidade e pode desencadear males maiores, pois, de acordo com estudos realizados em diversos países a ABRAPIA afirma que:

Aqueles que praticam Bullying contra seus colega poderão levar para a vida adulta o mesmo comportamento anti-social(sic), adotando atitudes agressivas no seio familiar (violência doméstica) ou no ambiente de trabalho. Estudos (...) já sinalizam para a possibilidade de que autores de Bullying na época da escola venham a se envolver, mais tarde, em atos de delinquência ou criminosos.

No entanto o dano maior ocorre com a vítima, pois, como afirmado por Soares (2013, p.14) “0 bullying retira a autoestima(sic), nos afasta dos sonhos, traz sofrimento, solidão e vergonha". Sérias sequelas são deixadas por essa violência como aponta A ABRAPIA :

As crianças que sofrem BULLYING, dependendo de suas características individuais e de suas relações com os meios em que vivem, em especial as famílias, poderão não superar, parcial ou totalmente, os traumas sofridos na escola. Poderão crescer com sentimentos negativos, especialmente com baixa autoestima, tornando-se adultos com sérios problemas de relacionamento. Poderão assumir, também, um comportamento agressivo. Mais tarde poderão vir a sofrer ou a praticar o BULLYING no trabalho (Workplace BULLYING). Em casos extremos, alguns deles poderão tentar ou a cometer suicídio.

Uma vítima do bullying procura isolar-se, fugir. Tognetta $(2005$, p.7) afirma que:

[...] crianças e adolescentes que se personificam como vítimas, são ansiosas, inseguras de sua autoimagem e de seus gostos e assim, podem ser muitas vezes, sensíveis e caladas porque não têm como revidar, por medo, ou por não terem forças suficientes para isso. Não denunciam por vergonha ou medo das represálias e essa é sua grande dificuldade. (...) não denuncia, não contra-ataca influenciada pela insegurança [...].

No entanto, a forma de enfrentar o problema é não se intimidar e buscar ajuda, pois, o que o agressor deseja é ter alguém que lhe seja submisso, com quem ele possa exercer o seu poder, sua força, se auto afirmar.

\subsection{CONSIDERAÇÕES FINAIS}

Diante do exposto, conclui-se que o Serviço Social, bem como a unidade escolar em seu todo, para minimizar a prática do bullying na escola, devem criar estratégias que colaborem na descoberta dos casos, sendo uma delas a identificação das características que acompanham o bullying, pois, como já se evidenciou anteriormente, tanto vítima quanto agressor apresentam características peculiares, que se bem observada, poderá servir de apoio para prevenir o acontecimento e intervir quando já estiver ocorrendo, como também para minimizar suas consequências. Para tanto, deve-se atentar ao comportamento dos alunos principalmente nos intervalos de aula, no recreio, e quando possível, no momento da saída da escola.

Mas, ao identificar o bullying, deve se buscar enxergar o que está por trás da agressão, e o que ocasionou a violência. Não deve se deter na aparência, não se limitar a atuar apenas com o que está posto, ou evidente, e sim buscar a essência, atentar ao cotidiano dos envolvidos, e seus respectivos familiares, realizando uma 
análise da vivência familiar, pois, muitas vezes, os próprios pais, mesmo sem intenção estimulam seus filhos a esse tipo de violência, quando praticam bullying em casa, ao utilizar apelidos depreciativos; neste sentido, a criança na escola buscará se auto afirmar, repetindo o que lhe fizeram. Também estimulam quando são omissos, ou quando não estabelecem limites em casa.

Assim, a atuação do Serviço Social para minimizar o bullying, só surtirá efeito com o envolvimento de todos, de modo que, "[...] Independentemente das particularidades, qualquer plano de ação que se proponha a trabalhar com o problema do bullying escolar depende da compreensão que pais, professores e alunos compartilham sobre o fenômeno [...]". Como afirma Cubas (2006, p.205).

O Serviço Social então deve realizar atividades que possibilitem a identificação dos casos, a exemplo de reuniões, roda de conversas, palestras, oficinas que tratem do tema. Assim como, estimular a conscientização dos familiares, alunos, demais profissionais que compõem a escola e que necessitam de um entendimento aprofundado dessa problemática, sobre as consequências tanto para quem pratica, quanto para a escola. Contudo, deve-se também observar com atenção as falas dos agressores, na tentativa de encontrar nas entrelinhas a razão da agressão. Porém, no caso de encontrar uma demanda que esteja para além das atribuições do assistente social, este deve buscar o apoio da rede socioassistencial, viabilizar acessos através de encaminhamentos, de modo que, a vítima e o agressor recebam o acompanhamento que a demanda requer.

Por hipótese alguma se devem subestimar os efeitos do bullying em suas vítimas. Como foi relatado neste artigo, não é raro que as consequências traumáticas da violência sofrida podem culminar em suicídios, portanto é de extrema importância que as atenções aos primeiros sinais do problema sejam tratadas de forma mais efetiva para que se possa atingir o principal objetivo traçado, ou seja, o combate a esta prática nociva e destrutiva.

\section{REFERÊNCIAS}

[1] Abrapia. Associação Brasileira Multiprofissional de Proteção a Infância e a Adolescência Programa de redução do comportamento agressivo entre estudantes, disponível em: <http://www.observatoriodainfancia.com.br/IMG/pdf/doc-154.pdf. Acesso em 16/ago/2015 z.

[2] Brasil. Constituição (1988). Constituição da República Federativa do Brasil. Brasília, DF: Senado, 1988.140 p.

[3] Novo Código Civil. Lei no 10.403 de 10 de janeiro de 2002. Aprova o novo código civil brasileiro. Brasília, $\overline{\mathrm{DF}, 2002 .}$

[4] __ Estatuto da Criança e do Adolescente. Lei no 8.069 de 13 de julho de 1990. Dispõe sobre o Estatuto da Criança e do Adolescente e dá outras providências. Brasília, DF, 1990.

[5] Benavente, Isabel Menéndez. Bullying: acoso escolar. Disponível em <www.isabelmenendez.com . Acesso em: 15/10/2004 apud Tognetta, Luciene Regina Paulino (2005). Violência na escola: os sinais de bullying e o olhar necessário aos sentimentos. In: Pontes, Aldo; De Lima, V. S.: Construindo saberes em educação.) Porto Alegre: Editora Zouk. Disponível em: < http://www.mpsp.mp.br/portal/page/portal/Educacao/Doutrina/Bullying.pdf $>$ Acesso em:31/Ago/2015.

[6] Cubas. Viviane de Oliveira. Bullying: assédio moral na escola In: Violência na escola : um guia para pais e professores / Caren Ruotti, Renato Alves, Viviane de Oliveira Cubas. - São Paulo: Andhep : Imprensa Oficial do Estado de São Paulo, 2006.cap. 5 p.175-205

[7] Fante, Cleo. Fenômeno Bullying. Como prevenir a violência nas escolas e educar para a paz. Campinas: Editora Verus, 2004. Apud Tognetta, Luciene Regina Paulino (2005). Violência na escola: os sinais de bullying e o olhar necessário aos sentimentos. In: Pontes, Aldo; De Lima, V. S.: Construindo saberes em educação.)Porto Alegre: Editora Zouk. Disponível em < http://www.mpsp.mp.br/portal/page/portal/Educacao/Doutrina/Bullying.pdf $>$ Acesso em:31/Ago/2015

[8] Iamamoto, Marilda Villela. Serviço Social na Contemporaneidade: Trabalho e formação Profissional: - 3. ed. São Paulo, Cortez, 2000.

[9] Carvalho. Raul. Relações Sociais e Serviço Social no Brasil esboço de uma interpretação históricometodológica. 37ä. Ed. São Paulo: Cortez, 1983.

[10] João Pessoa.( Município) Câmara Municipal. Lei № 11.385, DE 16 DE JANEIRO DE 2008. Cria O Serviço Social Escolar Nas Escolas Públicas Do Município De João Pessoa E Adota Outras Providências. Disponível em < https://www.leismunicipais.com.br/a/pb/j/joao-pessoa/lei-ordinaria/2008/1139/11385/> Acessado em 16/Agos/2015.

[11] Olweus, Dan. Bullying at School: what we know and what we can do.0xford: Blackwell Publishing, 1993.apud Cubas. Viviane de Oliveira. Bullying: assédio moral na escola In: Violência na escola : um guia para pais e professores / Caren Ruotti, Renato Alves, Viviane de Oliveira Cubas. - São Paulo: Andhep : Imprensa Oficial do Estado de São Paulo, 2006.cap. 5 p.175-205

[12] Ruotti, Caren .Violência na escola : um guia para pais e professores / Caren Ruotti, Renato Alves, Viviane de Oliveira Cubas. - São Paulo : Andhep : Imprensa Oficial do Estado de São Paulo, 2006. Disponível em< http://www.imprensaoficial.com.br/PortalIO/download > Acesso em: Acesso em: 16/ago/2015 
[13] São Paulo. (Estado). Assembleia Legislativa Decreto N. 9.744, de 19 de Novembro de 1938 Reorganiza o Serviço Social dos Menores, do Departamento de Serviço Social, e dá outras providências Disponível em < http://www.al.sp.gov.br/repositorio/legislacao/decreto/1938/decreto-9744-19.11.1938.html> Acessado em 18/Ago/2015

[14] Soares. Alexandre Saldanha Tobias, Bullying e Direito. Editora Online Corujito, 2013 disponível em < http://alexandresaldanhaadvogadoantibullying.blogspot.com.br/2013/08/livro-bullying-e-direito-download.>Acesso em Acesso em: 16/ago/2015

[15] Teixeira Gustavo, Manual Antibullying para alunos, pais, e professores, Rio de Janeiro, Best-seller, 2011.apud SOARES. Alexandre Saldanha Tobias, Bullying e Direito. Editora Online Corujito, 2013. disponível em < http://alexandresaldanhaadvogadoantibullying.blogspot.com.br/2013/08/> Acesso em: 16/ago/2015

[16] Tognetta, Luciene Regina Paulino (2005). Violência na escola: os sinais de bullying e o olhar necessário aos sentimentos. In: Pontes, Aldo; De Lima, V. S.: Construindo saberes em educação.)Porto Alegre: Editora Zouk. Disponível em: <http://www.mpsp.mp.br/portal/page/portal/Educacao/Doutrina/Bullying.pdf >Acesso em:31/Ago/2015 


\section{Capítulo 13}

Educação e Direitos Humanos: Um diálogo voltado para educação intercultural como garantia de direitos

\section{Camila Mirella Barbosa Raia De Oliveira}

\section{Edina Henrique Da Silva Batista}

Resumo: Este artigo tem como objetivo principal analisar o direito à educação, a partir das concepções de direitos humanos e interculturalidade como aproximação das questões relacionadas às diferenças. 0 estudo em pauta é um recorte de pesquisa intitulada: "Educação em Direitos Humanos e Formação de Professores no Ensino Fundamental", desenvolvida pelo grupo de pesquisa "Interlocuções entre Educação em Direitos Humanos, Currículo e Formação de Professores", desenvolvido pela UFPE, no Núcleo De Estudos e Pesquisas de Educação em Direitos Humanos, Diversidade e Cidadania - NEPEDH, vinculada a CNPQ/BR. A pesquisa assinala estudos científicos (dissertações e teses), selecionado os trabalhos que foram desenvolvidos entre os anos 2011-2016, coletados nos bancos de dados oficiais da Biblioteca Digital Brasileira de Teses e Dissertações, Banco de Teses da Capes e Domínio Público. Vale ressaltar que o mediante estudo busca analisar os trabalhos supracitados que contemplam a temática: Inclusão, Direitos Humanos e interculturalidade.

Palavras-chave: direitos humanos, educação, interculturalidade. 


\section{INTRODUÇÃO}

Muito se discuti nos Âmbitos Legais no que tange o processo da Educação em Direitos Humanos, e o processo histórico de algumas referências se funda com o período transitório democrático na América Latina e no Brasil. Em consonância com exposto Andrade e Rechembah (apud Tavares 2015, P. 16) afirmam que "A construção da educação em e para os direitos humanos como política pública vem sendo parte de um processo global, regional e local, envolvendo a sociedade civil e o Estado".

Por conseguinte, A Declaração Universal dos Direitos Humanos, proclamada em 1948, demarca "que cada indivíduo e cada órgão da sociedade [...] se esforce, através do ensino e da educação, por promover o respeito a esses direitos [...]" (ONU, 1948, preâmbulo). Contudo o direito à educação é descrito em seu artigo 26, que viabiliza orientações no sentido do "pleno desenvolvimento da personalidade humana e do fortalecimento do respeito pelos direitos humanos e pelas liberdades fundamentais" (ONU, 1948, art. 26).

Destarte, percorrendo o caminho das análises e reflexões apresentadas no grupo de pesquisa surgem nossa indagação: quantos trabalhos foram apresentados ao mundo acadêmico (dissertações e teses), no período de 2011 a 2016 relacionados aos direitos humanos que apresentam a temática da educação intercultural?

E, assim para responder a esse questionamento, traçou-se como objetivo geral identificar os trabalhos (dissertações e teses) realizados no período de 2011 a 2016 que contemplam educação em direitos humanos e interculturalidade. Apoiados pelos caminhos dos objetivos específicos: (1) Identificar quantitativamente o levantamento de tais dados; (2) Verificar nos trabalhos citados anteriormente, os fundamentos que orientam a temática destas políticas educacionais, voltadas para a garantia dos direitos; (3) Analisar a temática em questão, identificando os avanços e caminhos necessários para o mesmo.

Justifica-se este artigo a partir do interesse do grupo de pesquisa em Direitos Humanos a respeito da temática, para que, se adentre as discussões mais atuais sobre o contexto e como estão se posicionando os aportes teóricos frente a uma educação em direitos humanos. A reflexão e o debate sobre direitos humanos e educação, apresentam um número considerável incluindo documentos oficiais, porém o que distância é a apropriação do conhecimento e sua prática. Pretende-se com esse estudo, contribuir para as instâncias das políticas educacionais nos espaços acadêmicos. Que este estudo possibilite averiguação dos pontos positivos e das melhorias a serem realizadas nas abordagens metodológicas apresentadas pelo meio científico.

\section{EDUCAÇÃO EM DIREITOS HUMANOS E INTERCULTURALIDADE}

A Educação em Direitos humanos vem contribuir para o estabelecimento desses valores. Segundo o Plano Nacional de Educação em Direitos Humanos - PNEDH (BRASIL, 2007, p. 25), a EDH articula as seguintes dimensões:

a) apreensão de conhecimentos historicamente construídos sobre direitos humanos e a sua relação com os contextos internacional, nacional e local;

b) afirmação de valores, atitudes e práticas sociais que expressem a cultura dos direitos humanos em todos os espaços da sociedade;

c) formação de uma consciência cidadã capaz de se fazer presente em níveis cognitivo, social, ético e político;

d) desenvolvimento de processos metodológicos participativos e de construção coletiva, utilizando linguagens e materiais didáticos contextualizados;

e) fortalecimento de práticas individuais e sociais que gerem ações e instrumentos em favor da promoção, da proteção e da defesa dos direitos humanos, bem como da reparação das violações.

A Educação em Direitos Humanos atravessa os muros das escolas e levar o aluno a um diálogo com o mundo e a incitá-lo ao questionamento e ao reconhecimento do outro. Dessa forma, podem contribuir para o desenvolvimento de uma visão crítica da realidade e de uma consciência de sujeito histórico que pode se libertar de toda opressão e de toda injustiça. 
Uma Educação em Direitos Humanos deve ter como base a sensibilização, a consciência da dignidade de toda pessoa humana e a promoção de uma cultura dos Direitos Humanos. Candau (2005, p. 8) aponta alguns elementos relevantes para uma educação pautada no respeito aos direitos humanos, na dignidade do indivíduo, importantes para que educadores se baseiem e pratiquem nos seus espaços escolares.

- um processo sistemático e multidimensional orientado à formação de sujeitos de direitos e à promoção de uma cidadania ativa e participativa;

-a articulação de diferentes atividades que desenvolvam conhecimentos, atitudes, sentimentos e práticas sociais que afirmem uma cultura de direitos humanos na escola e na sociedade;

- processos em que se trabalhe, no nível pessoal e social, ético e político, cognitivo e celebrativo, o desenvolvimento da consciência da dignidade humana de cada pessoa.

Tratar a educação como um direito humano tem um sentido bastante amplo, vai além de ofertar educação para todas as pessoas, sem limitações seja financeira, de raça, cultura, condição social, nacional, de gênero ou étnico-racial, não se referindo somente ao processo escolar e sim nos diversos âmbitos, como, na família, comunidade, trabalho, grupos de amigos e associação. A educação é um bem público, pois ela dá acesso a outros direitos. A educação contribui para que as pessoas saiam da pobreza, evita a marginalização das mulheres, o trabalho infantil, a exploração sexual, possibilita o enfrentamento de discriminações e preconceitos, entre muitos outros benefícios.

Nas questões referentes as normativas, os avanços destacam-se a partir da promulgação da Constituição Brasileira de1988 (BRASIL/SENADO FEDERAL, 1988) garantindo os direitos políticos, econômicos, sociais para todos os brasileiros, entre estes a educação como um direito subjetivo, e a publicação de documentos balizadores que contribuam para fomentar/instituir políticas públicas de Direitos Humanos e de Educação em Direitos Humanos no território nacional. Os documentos citados, são: Os Programas Nacionais de Direitos a Humanos no Brasil, I, II e III elaborados nos anos de 1999, 2006, 2010, respectivamente; o Plano Nacional de Educação em Direitos Humanos construído em uma primeira versão em 2003 e, em segunda versão em 2006 (BRASIL, 2003/2006), as Diretrizes Nacionais para a Educação em Direitos Humanos (BRASIL, MEC/CNE, 2012) e mais recentemente as Diretrizes Curriculares Nacionais para a Formação Inicial e Continuada dos Profissionais do Magistério da Educação Básica (BRASIL, MEC/CNE, 2015).

Tal movimento no Brasil, cresceu a partir do envolvimento da sociedade civil organizada buscando a reconstrução e fortalecimento da democracia no país. Esses documentos reiteram a Lei de Diretrizes e Bases de 1996 (BRASIL, MEC/CNE, 1996) ao explicitar que a educação é instrumento de formação da cidadania e nessa direção de vetor para fortalecer a democracia.

No Brasil, sob ótica do currículo escolar, este sofreu grande influência na década de 1990, com a promulgação da nova Lei de Diretrizes e Bases da Educação Nacional em 20 de dezembro de 1996 LDBEN 9394/96. A LDB regulamentou o ensino em modalidades e as condições a serem oferecidas. Em 1997, é promulgado os Parâmetros Curriculares Nacionais (PCNs) que fornecem referências curriculares para orientação da escola na realização da reestruturação e/ou estruturação dos currículos escolares de todo o Brasil, com o objetivo de padronizar o ensino. No ano de 1998 foram promulgadas as Diretrizes Curriculares Nacionais (DCNs), normas obrigatórias para a educação básica, metas e objetivos que orientam o planejamento curricular e norteiam os currículos.

A escola por meio do currículo intervém no processo de compreensão de diversidade cultural por meio de práticas multiculturais que buscam superar questões como racismo, preconceito, violência, xenofobia, assim se faz necessária reflexão desse currículo multicultural na prática do professor e na sua formação docente. "Uma educação para o reconhecimento do outro, para o diálogo entre os diferentes grupos sociais e culturais" (CANDAU, 2013, p.23)

O currículo intercultural é o que, com uma base comum de cultura geral para todos, acolhe a diversidade e a experiência particular dos diferentes grupos de alunos e propicia, na escola e nas salas de aula, um espaço de diálogo e de comunicação entre grupos sociais diversos. (LIBÂNEO, 2011, p. 305).

É dessa forma que a educação intercultural ganha destaque. A interculturalidade vem trazendo ao longo das décadas uma crescente mudança na perspectiva de educação, na teoria e no estudo. Nasceu através do povo, da não aceitação de que sua cultura é menos que outra, de não aceitar apenas que uma cultura é a dominante e que todas as outras deveriam submeter-se; surgiu para fazer valer os direitos que foram 
dados à todos os indivíduos. Como fundamenta Catherine Walsh (2010) conceito de interculturalidade não significa apenas o contato entre culturas, mas uma preocupação em desconstruir as relações desiguais de poder que subalternizam alguns grupos.

A interculturalidade influenciou as concepções teóricas a respeito da educação, Candau (2010, 2013), Freire (1996), Libâneo (2011), Santos (2002, 2003) e Walsh (2010), a partir do momento que, por ser um elemento que influencia os alunos e a sociedade, por todos os fatores externos chegarem até a escola, tratando-se de um meio social, assim a afeta. Dessa forma, concepções acerca da interculturalidade motivaram mudanças nas teorias, de diretrizes e de currículo escolar. Em educação, surgiu como um repensar no que deve nortear a educação, quais valores devem ser trabalhados, ensinados na escola para que promova um ensino intercultural eficaz. Trabalhar essas diversidades na escola é fundamental para a formação de um ser crítico e autônomo de sua aprendizagem. Para tanto, quando ocorre uma mudança importante na educação e que afeta o pensar, concepções e paradigmas, é necessário que o professor que está inserido na escola se prepare para receber essa mudança e saber trabalhar da forma mais coerente possível, abraçando e promovendo uma educação que forme para a diferença.

\section{METODOLOGIA}

Este estudo oportuniza compreender como se apresentam algumas pesquisas voltadas para a Educação em Direitos Humanos e Interculturalidade. À priori a pesquisa foi realizada de cunho quanto à natureza cientifica está enquadrada na base qualitativa, conforme Prodanov e Freitas $(2013$, p.70) "Considera que há uma relação dinâmica entre o mundo real e o sujeito, isto é, um vínculo indissociável entre o mundo objetivo e a subjetividade do sujeito que não pode ser traduzido em números".

O grupo de pesquisa surgiu com uma parceria da Universidades da Bahia (UNEB), que apresentou um projeto intitulado "Interlocuções entre educação em direitos humanos, currículo e formação de professores", tal projeto objetiva responder a essas inquietações, através de um mapeamento e análise da produção cientifica, delimitando as áreas de Educação em Direitos Humanos na interface com os campos do Currículo e a formação dos professores, com destaque para estudos relativos à educação formal, ao currículo da educação básica e da educação de jovens e adultos. 0 grupo de pesquisa, destaca como objetivo geral:

Analisar, no cenário da produção científica na área de Educação em Direitos Humanos, as possíveis interlocuções desta área com os campos de Currículo e Formação de professores, no período de 2005 a 2015, como forma de subsidiar processos formativos de professores, com foco na educação em direitos humanos. (COSTA, 2016, p. 12)*.

Elencando os seguintes objetivos específicos:

(1) Traçar um panorama das interlocuções entre as pesquisas de educação em direitos humanos, currículo e formação de professores; (2) Identificar enfoques e abordagens teórico-metodológicas que fundamentam a produção sobre a educação em direitos humanos na relação com, currículo e formação de professores; (3) Identificar e descrever, dentro da produção científica analisada, algumas ações, projetos, conteúdos trabalhados, experiências e práticas capazes de contribuir para a construção de propostas formativas em educação em direitos humanos. (Idem).

Foram construídas metas para garantir o que se espera alcançar neste processo investigativo, primeiramente a meta estabelecida será mapear a produção de conhecimentos sobre educação em direitos humanos com as possíveis interlocuções/interfaces com o campo do currículo e da formação de professores, posteriormente foi construída a meta para elaborar uma sistematização dos resultados da investigação com vistas a sua divulgação de forma a contribuir com a formação dos professores. A seguir apresenta-se os indicadores de acompanhamento com base para maior aproximação da organização das atividades que foram desenvolvidas no grupo de pesquisa. 
Tabela 01: indicadores de acompanhamento. (COSTA, 2016, p. 12)

\begin{tabular}{|c|c|c|c|}
\hline Item & Metas & Atividades & Indicador físico \\
\hline \multirow[t]{5}{*}{1} & $\begin{array}{c}\text { Mapear a produção de } \\
\text { conhecimentos sobre } \\
\text { educação em direitos } \\
\text { humanos com as possíveis } \\
\text { interlocuções/interfaces } \\
\text { com o campo do currículo e } \\
\text { da formação de professores. }\end{array}$ & $\begin{array}{l}1.1 \text { Definição dos descritores para a } \\
\text { busca: educação em direitos humanos e } \\
\text { educação e direitos humanos, currículo, } \\
\text { formação de professores }\end{array}$ & Descritores definidos \\
\hline & & $\begin{array}{l}\text { 1.2 Consulta nas bases de dados na } \\
\text { Biblioteca digital brasileira de teses e } \\
\text { dissertações e no Banco de Teses da } \\
\text { CAPES e Domínio Público }\end{array}$ & $\begin{array}{l}\text { Registro das Consultas } \\
\text { realizadas }\end{array}$ \\
\hline & & 1.3 Leitura seletiva do material & Material selecionado \\
\hline & & $\begin{array}{l}\text { 1.4 Leitura e fichamento das teses e } \\
\text { dissertações selecionadas e organização } \\
\text { dos dados em categorias; }\end{array}$ & $\begin{array}{l}\text { Fichamento do } \\
\text { material selecionado }\end{array}$ \\
\hline & & $\begin{array}{c}1.5 \text { Reunir os trabalhos selecionados em } \\
\text { um software }\end{array}$ & Software elaborado \\
\hline \multirow[t]{3}{*}{2} & $\begin{array}{c}\text { Sistematizar os resultados } \\
\text { da investigação com vistas à } \\
\text { sua divulgação de forma a } \\
\text { contribuir com a formação } \\
\text { dos professores }\end{array}$ & 2.1 Análise das informações/dados & $\begin{array}{l}\text { Informações/dados } \\
\text { analisados }\end{array}$ \\
\hline & & $\begin{array}{l}\text { 2.2 Realização de seminários e } \\
\text { apresentação de trabalhos em eventos e } \\
\text { publicações. }\end{array}$ & Seminário realizado \\
\hline & & 2.3 Redação do texto final & Texto final elaborado \\
\hline
\end{tabular}

Com o objetivo de conduzirmos nossa pesquisa, foram utilizados alguns sites de referência nas seguintes bibliotecas digitais:

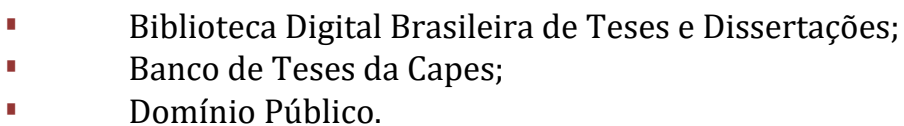

Entretanto, para realização desta, usamos dissertações e teses direcionando a definição de pesquisa documental que se aplica nesse trabalho, porque, lançamos mão da ideia que resulta a definição de (PRODANOV; FREITAS, 2013, p. 56) “[...] qualquer registro que possa ser usado como fonte de informação, por meio de investigação, que engloba: observação [...]; reflexão [...]; leitura [...]; crítica [...]". Visto que, nos apropriamos de trabalhos científicos, os quais tenham recebido tratamento analítico em outros estudos, mas não com os objetivos dos quais tratamos. Conforme foi definido, o recorte do estudo tratou-se de selecionar textos científicos, a partir de 2011 até 20016, que realizavam suas discussões sobre Educação e Direitos Humanos e interculturalidade.

Inicialmente, foi apresentado o projeto pela professora do grupo de pesquisa da UFPE, apresentou a proposta, o projeto (citado seus objetivos e indicadores anteriormente) e nele foi descrito as tarefas de cada membro, sugerindo que o grupo de pesquisa da UFPE, pesquisasse sobre as interlocuções entre educação em direitos humanos e formação de professores.

Em vista disso, foi abordado também que há necessidade de definir uma sistemática para realizar as buscas nas bases de dados. Conforme ficou estabelecido nos objetivos específicos do projeto, nossas ações durante a leitura das teses e dissertações devem conduzir ao seguinte:

- Identificar enfoques e abordagens teórico-metodológicas dos autores pesquisados;

- Descrever, conforme identificado nos trabalhos analisados, ações, projetos, conteúdos trabalhados, experiências e práticas voltadas para a Educação em Direitos Humanos (EDH).

Estabelecendo critério para o levantamento dos trabalhos, alguns descritores foram elencados para nortear a pesquisa, que foram:

- EDH e currículo 
- EDH e formação de professores

- $\quad$ Educação em direitos humanos

- Direitos humanos e educação

- Direitos humanos e formação de professores

- Direitos humanos e saberes docentes

Para garantir as atividades e crescente evolução do trabalho de pesquisa, foi preciso listar atividades em conjunto a elaboração de um cronograma de reuniões e entregas de resultados alcançados, para consolidarmos cada etapa concluída, ficando assim estabelecido em um encontro mensal presencial e cotidianamente por e-mail e plataformas de relacionamento social, podendo sofrer alteração o calendário em questão. Como posto na metodologia, foi realizada uma busca nas bibliotecas digitais por cada descritor mencionado, sendo os anos divididos para os membros do grupo.

Por conseguinte, para facilitar foi criada uma tabela com os registros das produções científicas pesquisadas, como forma de registrar o levantamento desenvolvido e registrar as pesquisas realizadas. Logo, foi concebido e concluído a fase direcionando a nossa análise.

\subsection{RESULTADOS E DISCUSSÃO}

Após a apreciação da metodologia, sobre a qual nos ancoramos para orientar nosso enfoque, seguimos com os resultados para uma reflexão mais apurada sobre o nosso tema de estudo, em prol de alcançarmos o cumprimento dos objetivos aos quais nos propomos atender. Como dito anteriormente, este artigo pretende identificar dentro do recorte realizado de 2011-2016, os trabalhos científicos (dissertações e teses) que contemplem educação em direitos humanos e interculturalidade.

Foram identificados no recorte do período de 2011-2016, cerca de 32 (trinta e dois) trabalhos (entre dissertações e teses) que tratam da temática da educação em direitos humanos que se relacionam aos descritores (destacados acima) para a pesquisa. Dessa amostra de 32 trabalhos, quando vamos analisar quais destes abordam a questão da interculturalidade, diminui-se para uma amostra de 02 (dois) trabalhos científicos. Tais trabalhos foram encontrados na plataforma do BDTD (Banco de Dados de Teses e Dissertações).

O primeiro trabalho encontrado, é do ano de 2015, pertence a Universidade de São Paulo - USP, intitulado "Igualdade e diferenças nas políticas educacionais: a agenda das diversidades nos governos Lula e Dilma", da autora Denise Carreira. O trabalho científico e uma tese, do programa do doutorado em educação, possui 508 páginas. 0 estudo se compromete em abordar as chamadas políticas de diversidade na educação e sua contribuição para o reconhecimento e a promoção dos direitos humanos e a superação do racismo, do sexíssimo, da homofobia e das demais desigualdades e discriminações que marcam profundamente a sociedade e a educação brasileiras.

0 segundo trabalho encontrado, é do ano de 2016, também pertence a Universidade de São Paulo - USP, intitulado "Educação, direitos humanos, igualdade e diferença: o que dizem os professores?", da autora Sara Motinho Silva. 0 trabalho científico e uma tese, do programa do doutorado em educação, possui 216 páginas. 0 estudo se compromete em ampliar o conhecimento sobre a relação entre direitos humanos e educação (histórico, conceitos, documentos) e buscar, por meio de entrevistas qualitativas com professores do ensino fundamental, levantar e sistematizar dados e reflexões que possam esclarecer as condições, favoráveis e desfavoráveis, para a implantação e consolidação de projetos de educação em direitos humanos em escolas públicas. (SILVA, 2016).

É importante destacar que nenhum dos dois trabalhos não tratam somente a questão da da interculturalidade, o trabalho de Carreira (2015, p. 25) busca fazer uma "relação entre a agenda da diversidade e os desafios de superação das desigualdades em educação." A autora aborda que sua pesquisa advém da sua prática profissional, além de educadora, ela é ativista, integra movimentos e organizações da sociedade civil, coloca a sua experiência como elemento fundamental para o seu projeto, para trabalhar a diversidade na educação e suas políticas educacionais. 0 trabalho de Silvia (2016, p. 14) a autora busca analisar o grau de conhecimento em relação a diversidade, a "percepção e tensões entre diferença e igualdade na dinâmica social do contexto escolar", atuando nas políticas educacionais. A interculturalidade está presente em conhecimento, nos preceitos que defende perante educação, não é a protagonista dos estudos aqui analisados, porém suas discussões servem de base, juntamente as questões referentes a diversidade e diferenças. 
O que pode ser percebido é a carência de estudos relacionados a direitos humanos dialogando com a interculturalidade, ao mesmo tempo, vemos uma crescente na sensibilização para tratar temáticas relacionadas ao preceito que a interculturalidade busca, como respeito a individualidade do sujeito de direito, a diversidade, as políticas que as permeiam, contexto que estão inseridas. Uma preocupação a ser destacada nos trabalhos analisados é em relação ao contexto escolar, como isso tudo chega para a escola, se os professores estão prontos para trabalhar as questões ligadas à diversidade na sala de aula, se houve uma formação que o preparasse para atuar de forma a garantir os direitos necessários aos educandos. Ainda são questões que inquietam estudiosos e que devem ser tratadas com muito cuidado de forma que produza conhecimento e evolução e não compreensões equivocadas que podem gerar atitudes que não condizem cm os preceitos da educação para a diversidade, de uma educação intercultural.

\section{CONCLUSÕES}

0 presente artigo reforça a importância da realização de mais estudos sobre a educação em direitos humanos e sua relação para uma educação intercultural. Quando analisamos as perspectivas interculturais vemos que ainda necessita de uma ampliação desse conhecimento, que vale enfatizar que está numa crescente no campo da educação, da sociedade. Atualmente conseguimos perceber que temas relacionados a diversidade, igualdade e diferença e interculturalidade está mais em evidência, não somente pelos estudos, mas por um movimento social crescente de garantias de direitos, de luta, de diálogos que auxiliarão a termos cada vez mais discussões tanto no micro, quanto no macro, com o objetivo de construir uma corrente de busca dos direitos e de conhecimento para que possamos atuar na realidade da nossa educação.

As escolas e os seus agentes, com destaque para os professores, devem estar cada vez mais envolvidos com a nova realidade inserida na matriz curricular escolar, na formação e na prática docente. A formação da sociedade brasileira diferentes culturas, a interculturalidade reforça a ideia de se desenvolver no campo da educação, um trabalho que contemple essa complexidade social dentro da realidade brasileira. Para isso é imprescindível, pensar e repensar a prática pedagógica docente, quanto a sua formação. Esse pensar e repensar se estabelece como essencial, tendo em vista que ainda há uma lacuna na vida profissional, na docência e na vida da escola.

Candau (2013, p. 86) alerta na questão do "cuidado com a forma como essas iniciativas pedagógicas poderão ser realizadas e a necessidade de articulá-las com os estudos e reflexões mais profundos". Para isso, é necessário que o professor se preocupe com o processo de construção da cidadania do aluno, fazendo com que seja necessária a conscientização do professor, que conforme Freire (1996) tem seu papel de facilitador de aprendizagem, aberto às novas experiências, procurando compreender, numa relação empática, também os sentimentos e os problemas de seus alunos e tentar levá-los à autorrealização.

\section{REFERÊNCIAS}

[1] Andrade, C. B. de Fenando; Rechenbach. Fabiana. Contribuições à Educação em Direitos Humanos na Contemporaneidade. Curitiba- Brasil, 2016

[2] Brasil. Constituição Brasileira. Brasília, Senado Federal, 1988.

[3] ___ Lei de Diretrizes e B. Lei no 9.394/96, de 20 de dezembro de 1996.

[4] _ Decreto n. - 1.904, de 13 de maio de 1996. Programa Nacional de Direitos Humanos 1. Revogado pelo Decreto n. 4.229 , de 13.5.2002. Brasília, SEDH/MJ, 1996a.

[5] _ Decreto n. Decreto n.o 7.037, de 2009. Brasília, SEDH/MJ, 2002.

[6] __ Decreto n. 7.037, de 21 de dezembro de 2009. Aprova o Programa Nacional de Direitos Humanos PNDH-3 e dá outras providências. Brasília, SEDH/MJ, 2009a.

[7] _ Ministério da Educação. Plano Nacional de Educação em Direitos Humanos: versão 2006. Brasília, MEC/SEDH, 2006.

[8] _ Parecer CNE/CP n.o 8/2012. Diretrizes Nacionais para a Educação em Direitos Humanos. Brasília, MEC/CNE, 2012a.

[9] __ Resolução CNE/CP n.o 01/2012, de 30 de maio de 2012. Estabelece Diretrizes Nacionais para a Educação em Direitos Humanos. Brasília, MEC/CNE, 2012b.

[10] _ _ _ Diretrizes Curriculares Nacionais para a Formação Inicial e Continuada dos Profissionais do Magistério da Educação Básica. Brasília, MEC/CNE, 2015.

[11] Candau, Vera Maria. Educação em direitos humanos: principais desafios. Rio de Janeiro: 2005. 
[12] ___ Russo, K. Interculturalidade e Educação na América Latina: uma construção plural, original e complexa Revista Diálogo Educacional. Rev. Diálogo Educ., Curitiba, v. 10, n. 29, p. 151-169, jan./abr. 2010.

[13] ___ Moreira, A. F. Multiculturalismo: diferenças culturais e práticas pedagógicas. 10. ed. Petrópolis: Vozes,

2013.

[14] Carreira, Denise. Igualdade e diferenças nas políticas educacionais: a agenda das diversidades nos governos Lula e Dilma / Denise Carreira; orientação: Profa. Dra. Roseli Fischmann, São Paulo, 2015.

[15] Costa, Graça dos Santos. Projeto de Pesquisa: Interlocuções entre Educação em Direitos Humanos, Currículo e Formação de Professores. Universidade do Estado da Bahia (UNEB), Salvador, 2016.

[16] Freire, P. Pedagogia da autonomia: saberes necessários à prática educativa. 36. ed. São Paulo: Paz e Terra, 1996.

[17] Libâneo, J. C.; Oliveira, J. F.; Toschi, M. S. Educação escolar: políticas, estruturas e organização. 10. ed. São Paulo: Cortez, 2011.

[18] ONU. Declaração Universal dos Direitos Humanos. Brasília, 1948. Disponível em: <http://www.oas.org/dil/port/1948\%20

declara\%C3\%A7\%C3\%A3o\%20Universal\%20dos\%20Direitos\%20Humanos.pdf>. Acesso em: 09 jun. 2016.

[19] Prodanov, C. C.; Freitas, E. C. de. Metodologia do trabalho científico: métodos e técnicas da pesquisa e do trabalho acadêmico. 2. ed. Novo Hamburgo: Feevale, 2013.

[20] Santos, B. de S. A globalização e as ciências sociais. São Paulo: Cortez, 2002.

[21] _ Reconhecer para libertar: Os caminhos do cosmopolitismo multicultural. Rio de Janeiro: Civilização Brasileira, 2003 .

[22] Silva, Moitinho Sara. Educação, direitos humanos, igualdade e diferença: o que dizem os profesores? / Sara Moitinho-Silva; orientação Maria Victoria de Mesquita Benevides. São Paulo: s. n., 2016.

[23] Walsh, Catherine. Interculturalidad crítica y educación intercultural. In: VIAÑA, Jorge; Tapia, Luis; Walsh, Catherine. Construyendo Interculturalidad Crítica. III - Cab. la Paz - Bolívia, 2010. 


\section{Capítulo 14}

O passado como experiência viva do eu no presente: Os desafios da memória dividida nos escritos de um apenado

\section{Charles Lamartine de Sousa Freitas \\ Ana Lúcia Oliveira Aguiar \\ José Evangelista de Lima \\ Francinilda Honorato dos Santos \\ Stenio de Brito Fernandes}

Resumo: Este artigo ergue-se de um projeto de extensão intitulado Histórias de Vida em Música, Teatro e Desenho - vozes silenciadas este artigo intitula-se 0 passado como experiência viva do eu no presente: desafios da memória dividida nos escritos de apenados propõe uma leitura a partir dos textos escritos por quarenta apenados do regime semiaberto masculino de um Complexo Penal Estadual, com o objetivo de compreender os desejos, as escolhas e as oportunidades do passado repercutindo no presente. Utilizaremos como metodologia as interpretações das narrativas escritas na dimensão de sua reflexiva autoformativa. Aponta a visão de superação das barreiras enfrentadas no cotidiano das suas histórias de vida antes e no tempo da prisão como transformadores levando a oportunidade de ressocialização. As memórias e identidades do passado, marcadas em suas histórias de vida, registradas em seus textos escritos e refletivos em suas narrativas permitem considerar a pertinência do salto qualitativo para pelo caminho do exercício da dizer, falar, purgar e a relevância das histórias de vida como lugar de aprendizagens formativos.

Palavras-chave: Histórias de Vida, Passado, Presente, Subjetividades, Apenados. 


\section{INTRODUÇÃO}

O projeto intitulado Histórias de Vida em Música, Teatro e Desenho - Vozes Silenciadas proposto pela Diretoria de Políticas e Ações Inclusivas (DAIN), tendo como equipe executora alunos do Programa de PósGraduação em Educação da Universidade do Estado do Rio Grande do Norte - UERN é um ação que vem sendo realizada, uma vez por mês, desde setembro de 2015, somando até hoje vinte e cinco ações, quando do lançamento pelo Ministério Público de Mossoró, chamado Projeto ReFaz, com a parceria da Universidade do Estado do Rio Grande do Norte, através da Pró-Reitoria de Extensão/UERN (PROEX). Objetiva trabalhar a construção de saberes e fazeres na perspectiva da ressocialização através do aprendizado da música, do exercício do teatro e do desenho. É um projeto como uma prática que busca promover a recuperação do detento no convívio social, considerando a Lei de Execução Penal e seus dois eixos: punir e ressocializar.

Fundamenta-se na busca pela (auto) formação, autonomia e independência dos sujeitos apenados, em seu lugar de vivência, pela troca de experiências e compartilhamento do seu saber/fazer, motivados pela verticalização de ações no mote Práticas Educativas, Cultura, Diversidade e Inclusão. Trabalhamos com as narrativas (auto) biográficas, desenhos, peças teatrais, histórias de vida de apenados, em rodas de conversas. Compreendemos que é preciso a viabilização de ações e políticas voltadas para a diversidade e inclusão instigando a construção das dimensões da vida de sujeitos apenados para a (re) socialização e o olhar para além do crime. Implica em ações com a visão para a diversidade e a inclusão de sujeitos privados de liberdade, considerando a responsabilidade da academia com sua prática para além dos muros.

A Ação intitulada Histórias de Vida em Música, Teatro e Desenho- vozes silenciadas proposto pela Diretoria de Políticas e Ações Inclusivas, em conjunto com alunos do Programa de Pós-Graduação em Educação da Universidade do Estado do Rio Grande do Norte - UERN, é um ação que vem sendo realizada, uma vez por mês, desde setembro de 2015 quando do lançamento do Projeto ReFaz, pelo Ministério Público, com a parceria da Universidade do Estado do Rio Grande do Norte, através da Pró-Reitoria de Extensão/PROEX/UERN. A PróReitoria de Extensão/UERN realizou uma reunião, em setembro de 2015, na Sala dos Conselhos momento no qual houve a participação de várias instituições locais, bem como de vários setores da UERN quando foi feito o convite a quem desejasse participar ofertando um projeto dentro do projeto guarda-chuva do Ministério Público. Em decorrência do convite, a Diretoria de Políticas e Ações Inclusivas Propôs o Projeto Terça Musical em História de Vida em Música, Teatro e Desenho inicialmente, que seria às terças feiras, mas que, em decorrência da necessidade de ajustes de horários ponto de vista da equipe executora e das atividades do Complexo Penal Estadual Agrícola Dr. Mário Negócio, optou em deixar aberto, sem indicar o dia da semana. Ao reafirmar o compromisso social da universidade como forma de inserção nas ações de promoção e garantia dos valores democráticos, de igualdade e desenvolvimento social, a ação se coloca como prática acadêmica que objetiva interligar a universidade, em suas atividades de ensino, com as demandas do dia a dia da sociedade como um todo. Sem dúvida o diálogo com a comunidade, o olhar atento para as barreiras da vida permitirão a troca e compartilhamento entre os saberes e fazeres, pois provocará a participação da comunidade acadêmica na construção de ações, com vistas ao atendimento às diferenças.

O princípio do compromisso social e educacional é central na ação. Projeto social se constrói com a participação dos sujeitos, forjada pelos sujeitos na construção social com o outro e em sua realidade prática. A Universidade do Estado do Rio Grande do Norte cumpre seu papel social e compromisso no resgate da dívida do longo tempo de exclusão de sujeitos submetidos ao silêncio. Implica ainda o imperativo de uma análise crítica da realizada, um olhar de estranhamento e de desnaturalização dos ambientes de modo a fomentar ações inclusivas, e, ao mesmo tempo, provocar novas necessidades para o desenvolvimento individual e coletivo. Essa missão encontra-se compatível às novas exigências sociais e educacionais que de uma instituição de ensino superior e da proposta da educação para o século XIX.

Dessa forma, diante de um novo modo de fazer educação, em que a informação, o conhecimento, a sensibilização para o outro, o aquecimento das energias para a superação e quebra de barreiras, a partir de todos e todas é fundamental. 0 saber acadêmico, aliado ao olhar para o cotidiano, bem como para o espaço de presídios, no caso dessa ação, possibilitará a geração de singularidades que desembocam em novos modos de produzir, em ações concretas. É nesse espaço que deve se inserir as atividades dos docentes, dos discentes, e dos técnicos administrativos através da institucionalização da inclusão e da diversidade universitárias, na busca de contribuições que efetivamente conduzam à melhoria da qualidade de vida dos apenados. 
Discutir com foco a temática de presídios e apenados é de extrema importância, pois apesar de hoje existir muitas leis que asseguram as pessoas privadas de liberdade em sua inserção à educação, não é bem isso que encontramos em todos os lugares, onde as barreiras atitudinais e até mesmo a falta de conhecimento, fazem com que as pessoas em presídios sejam pensados como um público não inserido na questão da educação pública.

Todas essas assertivas justificam a importância da proposta neste projeto de ação para aquecer as discussões e ações sobre o tema na Universidade do Estado do Rio Grande do Norte, como também fortalecer a participação constante da UERN em eventos, ministrando os conhecimentos relativos a este campo de conhecimento tanto dentro da instituição como na sociedade. Vem demonstrar o interesse da UERN pela construção de um ambiente inclusivo, tanto internamente dentro da academia, quando na sociedade em geral.

A ação tem como enfoque o qualitativo, com levantamento bibliográfico e da Legislação Federal sobre o objeto de estudo. Rodas de música, em histórias de vida, de desenhos e de teatro. Faremos registros escritos, fotográficos e Narrativas de vivências, ensino e formação. A Metodologia da História Oral vai de encontros com a voz dos sujeitos da ação, possibilitando à escutar de suas narrativas, a respeito das dificuldades enfrentadas no seu cotidiano, sobre seus maiores problemas no contexto físico, os aprendizados, desafios e superações que encontram no dia a dia.

Serão realizadas análises crítico reflexivas das narrativas dos sujeitos da pesquisa sobre as suas trajetórias de vida no presídio. Realizaremos estudos, leituras individuais/grupos e debateremos sobre os saberes e fazeres em presídios. Analisaremos de maneira críticareflexiva as narrativas e os relatos dos apenados.

A ação será realizada no Presídio Estadual Agrícola Dr. Mário Negócio, situado na cidade de Mossoró. Faremos roda de música, organização de peças teatrais e rodas de elaboração de desenhos e contação de histórias de vida em grupos focais de 40 apenados do regime semiaberto. Na roda de música, e contação de histórias de vida, faremos, de forma intercalada, a cada música uma narrativa de história de vida. Após cada narrativa teremos reflexões sobre os limites, as dificuldades, as possibilidades do exercício das situações a partir da troca de experiências entre as histórias de vida. Participarão da ação profissionais da área da Licenciatura em Música, da Pedagogia, da Licenciatura em História, do Curso de Direito. Após cada história, embalada pela música e o corpo em movimento, teremos um momento de reflexão sobre as histórias de cada um em desenhos. Cada apenado desenhará uma situação escolhida dentro de sua trajetória de vida com destaque a mais significativa, considerando o que a ação poderá repercutir de forma a permitir uma mudança de vida após o cumprimento de sua pena. As histórias de vida repercutiram em ensaios de peças teatrais.

\subsection{S ESCRITOS COMO FONTE POTENCIAL DE INTERPRETAÇÃO DA MEMÓRIA E DO EU NA MEMÓRIA}

\section{DIVIDIDA}

Este artigo intitulado, 0 passado como experiência viva do eu no presente: desafios da memória dividida nos escritos de apenados nasce da experiência de dois anos e meio do projeto Histórias de Vida em Música, Teatro e Desenho, destinada ao espaço prisional no Complexo Estadual Agrícola Dr. Mário Negócio de Mossoró. Optamos para este artigo identificar os desejos, as escolhas e as oportunidades do passado repercutindo no presente nas narrativas orais e escritas dos quarenta apenados participantes do referido projeto. Percorrerá um diálogo em Thompson (1992) ao propor estudos sobre a Memória e o Eu e Portelli (2002) em suas lições de perceber a memória dividida a partir da leitura sensível das histórias de vida de sobreviventes de um massacre, o senso comum ${ }^{10}$.

Na Memória e o Eu, Thompson (1992, p. 197) afirma ser toda percepção humana subjetiva, mas que a fonte oral nos permite desafiar essa subjetividade, pois tem a condição de "deslocar as camadas de memória, cavar fundo em suas sombras na perspectiva de desvendar as memórias ocultas". A condição de ouvir, escutar, falar, purgar, escrever dos apenados no lugar presídio, penetrar no mais profundo de sua intimidades, seus pavilhões, lugar onde dormem, comem, pensam, articulam, resistem, não é possível através de uma estrutura lógica exterior e nem pela imaginação de quem deseja escrever sobre manicômios, presídios e conventos, essas instituições totais nos termos de Goffman (2001). As palavras

10 Consideramos as reflexões sobre as histórias orais de sobrevventes em Portelli (1996) como criada e preservada pelo homem comum. Reporto-me aos escritos do referido estudiosos quando aborda os sobreviventes do Massacre de Civitela Val di Chiana, Toscana, em 29 de julho de 1944). 
orais ou escritas dos apenados nos oferecem a mistura de resistência e de liberdade; de confiança e de dúvida; de ilusão e de desilusão; de querer e não querer; de acreditar e não acreditar, mas de vontade de continuar fora dos ditames da rua, das armadilhas de suas próprias construções.

É, com a mesma conviç̧ão, um escape, uma fuga, um alívio da memória seletiva, organizativa, reminiscência que a música, o teatro e o desenho, com oficinas realizadas no referido projeto demonstra que a história de vida narrada e escrita, em seus textos, produzidos durante as roda de encontros, emergem uma fraqueza fortaleza e contem os silêncios significativos que produziram e produzem as referências e superações dos estigmas.

Thompson (1992) nos permite perceber os sentimentos, quando ao deixamos de lado teorizações abstratas, o mundo material para concentrarmo-no nos sentimentos a respeito do passado e nas relações entre as pessoas. Traz à tona sentimentos subjacentes por meio do confronto direto com membros da família, com relatos orais dos próximos. Nessa direção, a memória e o eu, para o referido autor revela complexidades de, emoções contraditórias, de amor e de ódio entrelaçados, típicas de relacionamentos íntimos.

Por sua vez Portelli (2002) aponta a relação da memória dividida entre a memória institucional e a memória da história narrada e escrita pelo poder e a memória dos sujeitos comuns. Uma memória que comemora a fortaleza dos instrumentos de dominação e de controle do sistema prisional, uma memória que se quer sobrepor como uma verdade como uma prática de perfeição desenvolvida pelo sistema prisional, organizado e eficiente para controlar e regularizar as histórias de vida e as táticas de correção para a vida dos apenados. Como sistema que elabora o que será necessário para a punição do crime. Por outro lado a memória preservada pelos apenados, por seus filhos, esposa e familiares focada na perda, no luto, nas lacunas pessoais e coletivas. Para Portelli essa memória acusa a memória da instituição como responsável por suas culpas e deslizes; por suas insalubridades e seus dispositivos de vida de errantes no mundo e com o mundo.

Essas duas memórias estão em constantes embates e rivalidades para validar seus esforços não só do ponto de vista das ideias e pensamentos, mas efetivamente física, de acordo com os estudos de Portelli sobre o massacre de CivitellaVal di Chiana, na Toscana em 1944 uma vez que a memória da resistência sobre o massacre violava as memórias e percas dos sobreviventes. Com igual pertinência os apenados e seus familiares responsabilizam o sistema prisional por violar suas memórias, aos disciplinar o corpo dos apenados sob suas regras e normas desconhecendo suas possibilidades e capacidades de sentir a ausência dos laços familiares. A memória oficial está mais interessada na verdade que escrevem e dizem do que na memória dos que dizem, pensam e sentem seus encarcerados. 0 que discutimos aqui é o fato de se considerar como prática diária o desconhecimento da memória dos que para os sistema são levados do que suas vozes com a devida seriedade de ouvir, escutar o que podem dizer sobre as regras, normas e prescrições das quais são o objeto da prática.

Thompson (1992), tratando da ligação entre memória e identidade, enfatizam ser através da memória, que indivíduos podem recuperar suas histórias de vida interrompidas, por processos históricos, ocasionados por traumas históricos vividos. A opção, pela discussão teórica com esses autores, vem a propósito, para este estudo, pois ao levantarem a história de pessoas em situação de "margem", aproximam-se da análise de processos sociais no cotidiano, no micro de suas possibilidades, enfeixando o comportamento dos indivíduos em seu contexto cultural. Por meio dessa relação de reciprocidade agonística temos a história daqueles submetidos aos subterrâneos da história, em cena, que, embora em meio aos condicionamentos da estrutura, traçaram, em compartilhamento com outros sujeitos da relação social, um tempo e lugar das vontades de um grupo, no caso os apenados. Outro aspecto é, ao se buscar a história do homem em seu cotidiano, através da memória, mediante a incorporação dos pequenos acontecimentos da vida cotidiana, temos a memória como reveladora de realidades que foram violadas pelos documentos escritos, nos temos de Thompson (1992). Em vista disso, esse indivíduo é aquele que, em grupo, não hierarquizado, luta em meio à lógica de um Estado interventor de suas relações familiares, quando vai tirar os órfãos do seio de suas tradições e, nesse momento, seguindo outro caminho, estes fundamentam suas ações em valores tradicionais, solidários e comunitários.

Thompson (1992) alerta para a importância da memória colaborando para a reconstrução do mundo social de pessoas submetidas às classes sociais mais elevadas como empregados, copeiros, jardineiros. É o trabalho de libertação da memória, as sutilezas da memória informando como as pessoas atuam na realidade e, o que é "tipicamente reprimido está tipicamente presente" (Thompson, 1992, p. 205). Então a possibilidade da memória efetuar um trabalho de rompimento mesmo quando expressa apenas 
sentimento, terá sido, por si só, positivo muito mais quando defende que recordar a própria vida é fundamental para o sentimento de identidade tendo a memória reminiscência o poder transformador.

Por discutirmos as narrativas orais e escritas dos apenados com base na memória do cotidiano da experiência em presídios; da criação de uma comunidade de pertença dentro de uma comunidade, cujos elementos eram estranhos aos seus (valores, costumes, memória); de conseguir, esse grupo, amparar sua memória pertença em meio a um universo simbólico que fortaleceu o laço social através de símbolos afetivos impregnados na alma; de aguçar, em meio à memória-saber do Estado, a memória ethos para manutenção de sua identidade e dignidade disseminadas durante a liminaridade, prescreveu-se como necessário ampliar, o estudo, com a cooperação de outras portas interpretativas.

\subsection{PASSADO E O EU NO PRESENTE COMO DESAFIO À MEMÓRIA DIVIDIDA}

Podemos compreender mais daquilo que não é dito quanto uma nova sensibilidade desencadeada na prática da educação das sensibilidades, a capacidade de perceber o que pode ter faltado afirma Thompson (1992). A ausência das lembranças pela da repressão nas narrativas orais, nas narrativas escritas, aprender a estar atento àquilo que não foi dito, escrito, considerar os silêncios, as lacunas, as falhas no escrito, no falado. 0 referido autor diz que é preciso um ouvido mais perspicaz para as sutilezas da memória, da comunicação mais do que a chave de um quarto secreto. 0 que está tipicamente reprimido também está tipicamente presente, continua Thompson.

Vamos trabalhar com uma carta escrita por um apenado para sua mãe. Pedimos em uma das oficinas que escrevessem para alguém de sua família e denominamos a atividade como Carta do Perdão. A atividade foi realizada no dia 20 de novembro de 2017, durante o período da tarde. Alguns sabiam escrever, outros não. Em decorrência fomos escribas dos que não estavam, ainda, alfabetizados. Optamos pela Carta de Perdão do apenado que pediu para ser chamado de Céu, pois nos disse que quando pequeno sua mãe mostravalhe o céu cheio de estrelas em noites limpas. Céu nos disse que gostava de contar as estrela para esperar se nasciam verrugas como diziam os mais velhos. Lágrimas vieram aos seus olhos no momento da escrita. Nos escritos de Estrela vimos que ele sentia vontade de lutar e de renovar suas esperanças, a despeito de ter passado muitos dias no pavilhão sem querer sair para não se deparar com o céu estrelado. Ao perguntarmos a razão de não querer utilizar os momentos de abertura dos cadeados do pavilhão ele me disse que sentia raiva e culpava sua mãe por o ter estimulado a contemplar o céu. Leiamos o dito pelo apenado:

Todas as noites de dias não chuvosos minha mãe levava todos os filhos para fora de casa. 0 céu estrelado era para a minha mãe como uma mensagem de Deus sobre seu poder de ter criado o céu e a terra. Minha mãe dizia que nós chegaria s ao céu se estudasse e praticasse coisas boas. Ela dizia que o estudo era tudo na vida. Matriculava todos os anos os filhos na escola. Eram oito irmão, mas eu fingia que ia para a escola e no caminho fugia para conhecer outras coisas. Eu tinha vontade de ver o mundo como era, as rua, o comercio. Eu queria chegar como uma estrela ao céu. Para mim era tudo chegar ao céu era ficar importante. Tenho raiva disso porque não consegui chegar a essa conquista. 0 céu que encontre foi a polícia. Eu nunca disse isso a minha mãe e tenho vontade de dizer, mas ela vai se sentir culpada e eu sou culpado porque ela nunca me ensinou a roubar. Minha mãe saía todos os dias para trabalhar catando papelão nas ruas (Narrativa de Céu, Mossoró, 2017).

Por meio da narrativa de Céu e da escuta dos seus relatos percebemos que liberta seu ódio por sua mãe e fala, mas conseguiu compreender com a purgação, com a libertação do que estava preso em sua memória, em seu ressentimento que sua mãe não era culpada de ter estimulado os filhos a perceber o céu comparando-o como um lugar de chegada ao sucesso. Da sua forma a mãe de Céu queria estimular os filhos a buscar longe suas possibilidades de viver outra vida diferente da que vivia e que criava seus filhos. As dificuldades do dia a dia, embora tomasse o dia e as horas de sua mãe ela ainda tinha tempo de ser carinhosa e procurar estimular os filhos a outra vida. Céu disse que dos oito irmãos três se formaram. Uma em pedagogia, um em enfermagem e outra irmã em matemática. 
Céu diz que seu pai foi um ausente e que ele presenciava, com muita inquietação, seu pai roubar o dinheiro que sua mãe guardava dos papelões que catava e vendia. Vejamos os escritos de Céu:

Nunca vi meu pai como um pai, porque um homem que rouba a própria mulher não merece ser respeitado. Eu tinha dez anos quando comecei a ver essas coisas dentro de casa e fui para o mundo, com raiva de tudo. Eu aprendi a roubar com meu pai e a pensar que a vida era fácil. Meu pai nunca trabalhou. Ele vivia uma vida folgada de bebida, mesa de bar e com mulher enquanto minha mãe trabalhava o dia todo. Eu via isso dentro de casa e fui me acostumando mesmo que eu não gostava por que ele fazia isso com minha mãe, mas fui me acostumando com a vida que eu pensava que era fácil (Narrativa de Céu, Mossoró, 2017).

Entre o amor e o ódio Céu externa seus sentimentos de confusão em seu dilema entre o exemplo de mulher trabalhadora em sua mãe e o exemplo de homem desocupado em seu pai. A base recebida foi uma mistura entre o que era certo e o que era errado e que ele provou fora de casa suas consequências. Céu se reporta, agora aos 22 anos, ao ter sido preso pela primeira vez, ao que chamamos de memória ressentimento. Do pai e da mãe uma mistura de verdade vivenciadas por ele nas lições da rua, lugar preferido para se refugiar das sua consciência que de um lado dizia que não era a vida certa e de outro lado abria-lhe o apetite estar no mundo sem regras e normas. Agora, no pavilhão do presídio, privado do que considerava ser uma vida boa e livre, percebe as lições de sua mãe como o caminho certo e se afoga em peso da consciência. Mais uma vez Céu nos narra e escreve em seu texto da Carta de Perdão sobre o lugar presídio. Em depressão, Céu ressente-se do mal causado por seu pai e por ele próprio a sua vida e compara o dia a dia no presídio como um pai desamoroso, desinteressado e frio. Aprisionado na alma pela forma severa como é tratado por agentes encontra-se com o perdido por não ter seguido os ensinamentos de sua mãe e não ter se formado como três dos seus irmãos. Sintamos os escritos de Céu:

Esse lugar é frio. Frio por que as paredes são úmidas, sem sol que entre por uma janela para iluminar nossos quartos separados por panos e frio por que as pessoas que trabalham aqui vê agente como sem recuperação. A gente aqui é como uma coisa, como um animal, como um troço qualquer. 0 poder é grande, tão grande que temos que dizer o que eles querem que agente diga. A ordem é deles. 0 que eles querem é feito. Tenho até medo de responder quando os agentes perguntam alguma coisa para não errar. Penso sempre no que vou dizer para acertar no que eles querem ouvir. É muito ruim isso (Narrativa de Céu, Mossoró, 2017).

Na escuta de Céu e na leitura do que escreve, nos seus escritos através de textos ou mesmo de seus desenhos percebemos a libertação da memória, identificamos as força das lembranças e sentimentos poderosos. Quando escrevem sobre a família, sobre o pai, sobre a mãe, sobre os filhos choram e, ao mesmo tempo, odeiam o sistema que os recolhe e que os deixa sem poder dizer o que pensam, com limitação de tempo para as relações de convívio quando estabelecem um tempo curto para as visitas e, às vezes, por alguma insubordinação nos pavilhões suspendem tais visitas. Disse-nos e escreveu Céu:

Vocês professores aqui é quando podemos falar o que sentimos, mas temos até medo de falar o que não devemos. Eu confio em vocês porque são professores não é? Sei que professores são aqueles que querem ensinar. Os dias que vocês vem aqui é como um alívio. Até esquecemos das dores e do sofrimento, mas quando vocês vão embora não sabemos o que vai acontecer (Narrativa de Céu, Mossoró, 2017).

Como diz Portelli (2002), que é uma falha da historiografia nunca ter considerado as vozes, o senso comum com a devida seriedade. Dizemos, para esta pesquisa, que as vozes dos sujeitos privados de liberdade, o ressentimento narrado e escrito não é só um conjunto de palavras soltas, vazias, mas é algo mais do que isso. Compreendemos forças de oposição presentes nos escritos e nos diferentes tipos de relações interiorizados nos apenados. Fica expresso formas de dominação, de subordinação e de insubordinação que acompanham os apenados em seus dias de pertencimento ao lugar presídio, aquelas que fazem história e memória. 0 ressentimento, o medo, o ódio, a frustração, o desengano e a esperança são como um impulso à transformação das realidades. Emerge sensibilidades questão sensível para a compreensão das relações entre os afetos e desafetos entre o ser e o não ser, entre o pertencer e o não pertencer, entre a sociedade, o Estado, a família. 


\section{CONSIDERAÇõES}

Neste artigo trouxemos pela via das narrativas orais e escrita, pelo caminho dos textos dos apenados do Complexo Estadual Agrícola Dr. Mário Negócio de Mossoró, a experiência do Projeto Histórias de Vida em Música Teatro de Desenho para refletirmos sobre 0 passado como experiência viva do eu no presente: os desafios da memória dividida nos escritos de um apenado para compreender os desejos, as escolhas e as oportunidades do passado repercutindo no presente. Por meio dos seus escritos e seus narrados de ressentimentos, a memora ausência, a memória do não dito, a memória dividia entre o poder, o fazer e o sentir abriu espaço para a purgação e o reconhecimento. 0 conflito interior foi menos um ponto de chegada do que de partida.

Percebemos o ressentimento da desobediência na voz de Céu por não ter escutado os conselhos de sua mãe e o ressentimento de um sistema prisional que os trata como coisa. Os detalhes das narrativas e impressas nos escritos saem de questões materiais para sentimentos e emoções que levam à narrativas com tom forte de humanização pela dor, pela perda, pelo luto em consequência das falhas cometida e em sua repercussão de impedimentos na vida. As escolhas, os desejos e as oportunidades construídas e perdidas ao longo da vida permitem mudanças na compreensão sobre a responsabilidade com a vida e a contribuição em levarmos a sério o senso comum que confere a essa memória relacionada ao passado com experiência viva e repercussão no tempo presente.

Com a mesma pertinência trouxemos um diálogo com os saberes em espaços prisionais possível pelas vozes e escritos dos apenados considerados como impossibilidades pelo sistema e pela sociedade que os estigmatiza pelo crime cometido, pune as famílias e se esquiva da responsabilidade sem perceber potencialidades no processo de ressocialização. As atividades realizadas dentro do cronograma de atividades do Projeto Histórias de Vida em Música, Teatro e Desenho elenca um repertório de dimensões reveladoras das possibilidades do dizível enquanto estimulado considerado indizível pela visão classificatória e mecânica como os apenados são pensados pela instituição.

\section{REFERÊNCIAS}

[1] Ansart, Pierre. História e memória dos ressentimentos. In: Memória e (RE) sentimento: indagações sobre uma questão sensível. Stella Bresciani e Márcia Naxara (Org.) São Paulo: Editora Unicamp, 2001.

[2] Freire, Paulo. Educação como prática da liberdade. Rio de Janeiro, Paz e Terra, 2000.

[3] Goffman, Erving. Manicômios, Prisões, Conventos. São Paulo: Editora Perspectiva, 2001.

[4] Portell, Alessandro. O Masssacre Val di Cjiana (Toscana: 29 de junho de 1944): mito, política e senso comum. In: Amado, Janaína; Ferreira, Marieta (Org.). Usos e abusos da história oral. 5a ed. Rio de Janeiro: Editora FGV, 2002.

[5] Thompson, E. P. A voz do passado. São Paulo: Paz e Terra, 1992. 


\section{Capítulo 15}

As condicionalidades do programa bolsa família (PBF) na educação: Um relato de experiência na Escola Municipal Nazinha Barbosa da Franca

Maria Aparecida Pereira

Maria Goretti Rodrigues de S. Oliveira

Nájila Brandão da Silva

Celyane Souza dos Santos

Maria de Fátima Leite Gomes

Resumo: 0 presente trabalho refere-se a um relato de experiência enquanto resultado do projeto de extensão, intitulado: "O PROGRAMA BOLSA FAMÍLIA (PBF) E SUAS CONDICIONALIDADES NA EDUCAÇÃO: acompanhamento e monitoramento dos (as) alunos(as), em descumprimento na Escola Nazinha Barbosa da Franca", localizada no Bairro de Manaíra, em João Pessoa-PB, em que procura-se fazer uma análise das consequências das faltas dos alunos(as) matriculados(as) do $1^{\underline{0}}$ ao $5^{\circ}$ ano do Ensino Fundamental I, beneficiários do Programa de Transferência de Renda Bolsa Família (PBF). Objetiva-se, portanto, verificar o quantitativo de alunos que estão em descumprimento da frequência, a fim de buscar compreender as possíveis razões que contribuem para tal realidade social, bem como apresentar os dados e análises alcançados, na intenção de proporcionar à mencionada unidade escolar e a todos os segmentos envolvidos, elementos que viabilizem uma interlocução pautada em orientação crítica, quanto às sanções impostas pelo PBF. Assim, torna-se urgente criarem-se estratégias de estímulo à prevenção de tais situações. A presente análise sugere que a ausência em sala de aula ocorre em função das condições precárias em que vivem os alunos, associado aos graves problemas sociais, dentre eles: violência urbana e familiar, abandono familiar, tráfico de drogas, trabalho infantil, exploração sexual, Bullying, entre outros. Espera-se também, por meio desta análise, verificar quais os desdobramentos ocorridos, a partir da implementação do referido projeto, no tocante ao cumprimento da frequência, junto aos sujeitos inseridos neste processo.

Palavras Chave: Programa Bolsa Família, Condicionalidades, Educação 


\section{INTRODUÇÃO}

0 artigo em tela refere-se a uma análise sobre os(as) alunos(as) em descumprimento da frequência escolar na Escola Nazinha Barbosa da Franca, localizada no Bairro de Manaíra, na cidade de João Pessoa$\mathrm{PB}$, em que procura-se fazer uma análise das consequências das faltas recorrentes dos alunos(as) matriculados(as) do 1ํa ao 5o ano, do Ensino Fundamental I, beneficiários do Programa de Transferência de Renda Bolsa Família (PBF).

Os dados analisados são decorrentes da coleta realizada através do projeto de extensão, intitulado: "O PROGRAMA BOLSA FAMÍLIA (PBF) E SUAS CONDICIONALIDADES NA EDUCAÇ̃̃O: o acompanhamento e monitoramento dos(as) alunos(as) em descumprimento na escola Municipal Nazinha Barbosa da Franca", vinculado ao PROBEX - UFPB, desde 2015.

Deste modo, objetiva-se verificar o quantitativo de alunos que estão em descumprimento da frequência, a fim de buscar compreender as possíveis razões que contribuem para tal indicador social e, igualmente, apresentar os dados e análises alcançados, na intenção de proporcionar à mencionada unidade escolar, a todos os segmentos envolvidos, elementos que viabilizem uma interlocução pautada em orientação crítica, quanto às sanções impostas pelo PBF, aos que se encontra em descumprimento da frequência, a exemplo: advertência, bloqueio, suspensão e cancelamento da renda, de modo que criem-se estratégias de estimular a prevenção de tais situações.

Outrossim, a presente análise sugere que a ausência do alunado ocorre em função das condições precárias em que vivem, associado aos graves problemas sociais, dentre eles: violência urbana e familiar, abandono familiar, tráfico de drogas, trabalho infantil, exploração sexual, Bullying, entre outras razões que sinalizam o descumprimento da frequência escolar naquela localidade.

Espera-se, também, por meio desta análise, verificar quais os desdobramentos ocorridos, a partir da implementação do referido projeto, no tocante ao cumprimento da frequência, junto aos sujeitos inseridos nesse processo.

\section{METODOLOGIA}

A análise baseia-se em procedimentos da pesquisa social, de caráter quali-quantitativo, de modo que iniciou-se, primeiramente, através de uma revisão bibliográfica acerca da temática objeto desse estudo e, posteriormente, por meio da coleta dos dados documentais, a saber: diários de classe, relatórios mensais dos professores, comunicação escola-família, relatórios do PBF, encaminhamentos sociais, entre outros, sobre a frequência escolar dos(as) alunos(as) do ensino Fundamental I, do $1^{\circ}$ ao $5^{\circ}$ ano.

Deste modo, no processo de análise dos dados, buscou-se com base em um referencial teórico-crítico, fundamentar o objeto desse estudo, na perspectiva de compreendê-lo em sua totalidade, a fim de ordenar, catalogar e quantificar as informações obtidas, relacionando-as entre si, bem como ao contexto social em que estão situadas.

Na sequência, sistematizaram-se as categorias elencadas, à luz do pensamento crítico-reflexivo, na intenção de desnudar suas possíveis causas e consequências.

\section{RESULTADOS E DISCUSSÃO}

De acordo com os dados obtidos, no ano de 2015, a escola possuía 752 alunos matriculados. Destes, 386 estavam matriculados no Ensino Fundamental I. Dos 386, 303 recebiam o PBF, sendo que, 167 (dos 303) se encontravam em descumprimento da frequência escolar, representando um percentual de $55,12 \%$ do universo dos beneficiários do PBF. Em 2016, a escola dispõe de 774 alunos matriculados, a saber: o Ensino Fundamental I tem 369, desse universo, 273 são beneficiários do Programa Bolsa Família (PBF), e 146 estão em situação de descumprimento, o que corresponde a um total de $53.47 \%$ dos alunos beneficiários.

Tal realidade apresenta-se como recorrente, considerando-se o que demonstram os dados destacados no quadro 1 abaixo: 
Quadro 1 - Alunos beneficiários do PBF em descumprimento da frequência escolar 2015/2016

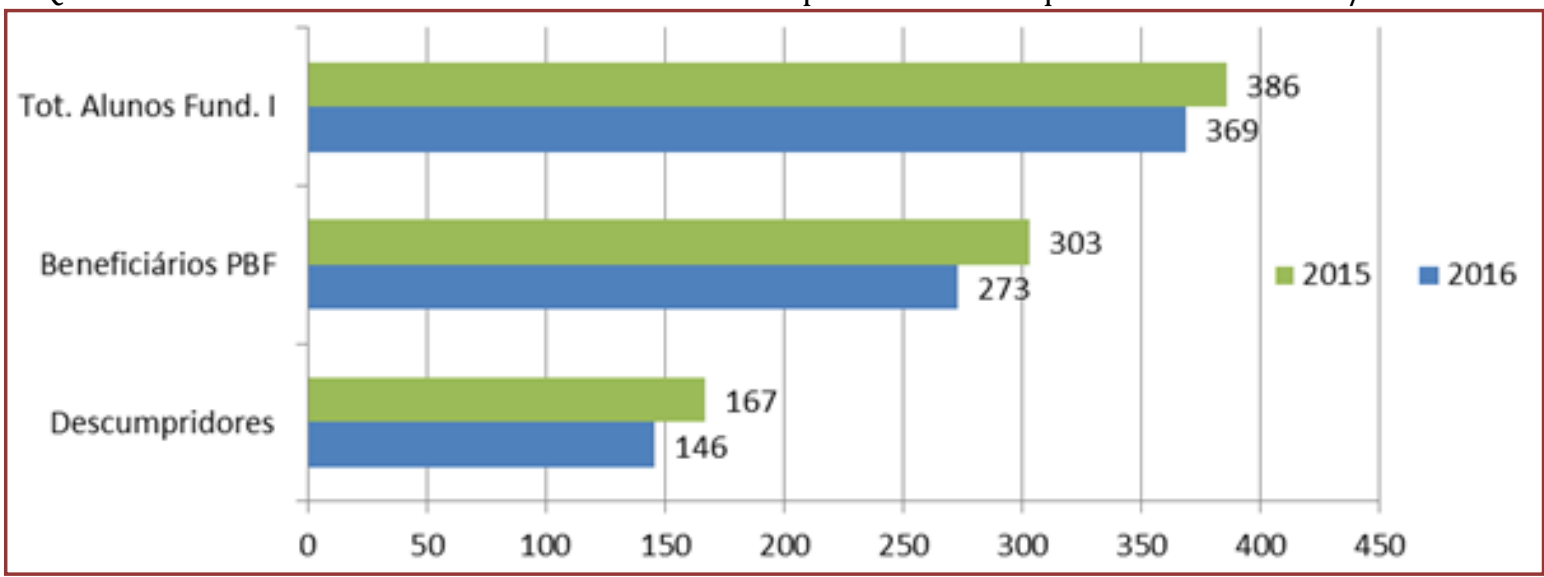

Fonte: Figura elaborada a partir de dados obtidos na Escola Nazinha Barbosa da Franca- 2015/2016.

Os dados supracitados demonstram um índice bastante elevado e preocupante, pois, conforme um dos objetivos do referido programa, a transferência de renda deve ser um elemento estimulador para viabilizar a participação da criança na escola, uma vez que, deverá possibilitar oportunidade de qualificação instrucional e inserção social, bem como garantir uma renda extra à família desta, cuja intenção é inviabilizar o trabalho infantil, ao tempo em que também garanta condições de sobrevivência a toda a sua família.

Como afirmado por Weissheimer, (2006, p.39) a cerca dos objetivos do (PBF):

0 principal objetivo do Programa Bolsa Família é justamente fazer com que seus beneficiados deixem de sê-lo. [...] Promover o desenvolvimento socioeconômico de famílias em estado de insegurança alimentar, gerar trabalho e renda, devolver ou mesmo criar uma dignidade capaz de levar a algo que possa ser chamado de cidadania.

Assim, embora o programa por si só não proporcione a emancipação da família, a transformação social, o intuito é que propicie condições para que a autonomia aconteça, o que só vai ocorrer mediante a educação.

No entanto, especificamente em 2016, na Escola Municipal Nazinha Barbosa da Franca, igualmente na contramão deste objetivo, comparando com o ano anterior, percebe-se uma discreta redução da infrequência escolar, pois ainda ocorre um expressivo índice de faltas e, o maior deles, registra-se entre os alunos dos $3^{\circ}$ anos. Contudo, o número de alunos reincidentes concentra-se nos $1^{\circ}$ anos, alcançando o percentual de $66,60 \%$, nos quais estão matriculados alunos cujos pais não participaram das reuniões realizadas, no intuito de orientá-los acerca das condicionalidades do PBF e da importância da educação para mudança social da família. Quanto aos $4^{\circ}$ anos, o percentual alcançado de reincidentes foi de $75 \%$, conforme aparece no quadro 2, abaixo:

Quadro 2 - Número de faltas dos alunos em geral e do PBF- 2016

\begin{tabular}{|c|c|c|c|c|}
\hline 2016 & $\begin{array}{c}\text { Total de faltas } \\
\text { (geral) }\end{array}$ & $\begin{array}{c}\text { Alunos } \\
\text { descumpridores } \\
\text { do PBF }\end{array}$ & $\begin{array}{c}\text { Alunos reincidentes do } \\
\text { PBF }\end{array}$ & Percentual de reincidentes do PBF \\
\hline $1^{\text {o Ano }}$ & 68 & 33 & 22 & $66,60 \%$ \\
\hline $2^{\text {o }}$ Ano & 58 & 29 & 17 & $58,60 \%$ \\
\hline $3^{\text {o }}$ Ano & 82 & 46 & 29 & $63,00 \%$ \\
\hline $4^{\text {o }}$ Ano & 54 & 28 & 21 & $75,00 \%$ \\
\hline $5^{\text {o }}$ Ano & 30 & 10 & 05 & $50,00 \%$ \\
\hline TOTAL & 282 & 146 & 94 & $64,30 \%$ \\
\hline
\end{tabular}

Fonte: Quadro elaborado a partir de dados coletados na Escola Nazinha Barbosa da Franca 
A partir dos elementos acima, pode-se definir a relação dos alunos em descumprimento e reincidentes, deduzindo-se, que:

[...] A condicionalidade em educação do PBF gera também alguns resultados indiretos muito importantes, como a ênfase no campo educacional da desigualdade socioeconômica e da vulnerabilidade de alunos em situação de pobreza, o que está relacionado à valorização da permanência da criança e do adolescente na escola e o combate ao abandono e à evasão escolar, portanto, a fim de reforçar o percurso educacional regular como um direito, sem interrupções, dos alunos das famílias de baixa renda. Para tanto, é importante incentivar a escola a identificar as causas da baixa frequência junto aos alunos e a suas famílias, com o apoio do diálogo intersetorial entre a educação e as demais áreas sociais, outro resultado indireto da iniciativa da condicionalidade em educação. (Castro e Modesto, 2010, p.165).

Assim, o processo de interlocução e de aproximação entre escola - família possibilita no PBF a identificação das mais diversas expressões da questão social, causadoras das situações de descumprimento, desde a simples falta de conhecimento acerca do mesmo, até o grau elevado de vulnerabilidade social dos núcleos familiares que comprometem o acesso à escola.

Neste sentido, na particularidade dos $75 \%$ de alunos(as) que são reincidentes, a devida constatação surge, a olho nu, como contraditória e incongruente, considerando-se que se trata de alunos(as) de séries mais avançadas, o que sugere estarem mais adaptados ao ambiente escolar. Contudo, devem-se ler os dados retratados com base em elementos em que se permita relacioná-los a aspectos subjetivos e objetivos da conjuntura econômica e social vigente.

Igualmente, entende-se que o PBF, na referida escola, não representa, isoladamente, o elemento central na garantia da frequência escolar. Pois, a inclusão de fato, só se conquista quando se garante o acesso a outros direitos sociais, e, neste caso, por meio dos relatos orais dos pais dos(as) alunos(as) dos $4^{\circ}$ anos, as crianças, nessa etapa de suas vidas, passam a almejar vários interesses que nem sempre estes pais possuem condições de lhes proporcionar.

Desta forma, esta expressão da questão social esbarra em outro fator básico e tão importante quanto o primeiro: a ausência de conscientização, decorrente principalmente da falta de conhecimento. Infelizmente essa realidade permanece presente, o que sinaliza a importância da informação contínua.

\section{CONCLUSÕES}

Diante dos dados analisados, a princípio, percebe-se que na Escola Municipal Nazinha Barbosa da Franca, há uma discreta redução no quantitativo de alunos em situação de descumprimento, $(1,65 \%$ a menos que no ano anterior). Contudo, os dados também apresentam um número expressivo de alunos que não comparecem às aulas, assim como de reincidentes, tornando evidente que o índice dos alunos beneficiados pelo PBF, que não cumprem com a porcentagem mínima exigida de frequência escolar mensal, ainda é muito alto, e necessita de intervenções que estimulem de maneira mais aprofundada a importância da frequência escolar. Porém, salienta-se que a frequência não se trata de um mecanismo apenas para manter o PBF, e sim para que no futuro ocorra a emancipação, a transformação social, o que poderá proporcionar a saída da família do referido programa. É preciso, também, que ao se constatar a infrequência, busque-se identificar as causas, pois, além das expressões da questão social que ocasionam a necessidade do benefício, podem ocorrer outras que causam a infrequência, e estas precisam ser minimizadas e se possível sanadas, para que não ocorram ou reduzam o índice de descumprimento das condicionalidades.

Para tanto, faz-se necessário que a equipe multidisciplinar da referida escola trace outras estratégias, além das aplicadas no ano anterior, de maneira a reconduzir à sala de aula os alunos em situação de infrequência escolar, uma vez que as ações realizadas não atenderam satisfatoriamente aos objetivos almejados, resultados estes que só irão ser alcançados quando existir uma maior parceria entre a escola e a comunidade, bem como a informação contínua acerca das condicionalidades do programa.

\section{REFERÊNCIAS}

[1] Brasil, República Federativa. Diário Oficial da União. Portaria Interministerial no 3789, de 17 de novembro de 2004. Estabelece atribuições e normas para o cumprimento da Condicionalidade da Frequência Escolar no Programa Bolsa Família.

[2] Castro, Jorge Abrahão de. Modesto, Lúcia (Org). Avanços e Desafios Bolsa família 2003-2010 : Brasília : Ipea, 2010. 2 v. (344p.) 
[3] Cotta, Tereza Cristina; Paiva, Luís Henrique. O Programa Bolsa Família e a Proteção Social no Brasil. In: 20032010: Bolsa Família 2003-2010: avanços e desafios. V.1, IPEA.

[4] Gomes, Maria de Fátima Leite. O Programa Bolsa família (PBF) e suas condicionalidades na educação: o acompanhamento e monitoramento dos(as) alunos(as) em descumprimento na Escola Municipal Nazinha Barbosa da Franca - João Pessoa, 2016

[5] Pires, André. Afinal para que servem as condicionalidades em educação do Programa Bolsa Família?. Ensaio: aval. pol. públ. Educ. Rio de Janeiro, v. 21, no 00.2013.

[6] Weissheimer, Marco Aurélio. Bolsa família: avanços, limites e possibilidades do programa que está transformando a vida de milhões de famílias no Brasil. São Paulo: Editora Fundação Perseu Abramo, 2006. 


\section{Capítulo 16}

\section{A importância do FIES na garantia do direito ao ensino superior}

\section{Silvana Santos Almeida}

\section{Felipe Almeida Garcia Santos}

Resumo: A presente pesquisa tem por escopo classificar o direito ao ensino superior como um direito fundamental do cidadão e dever do Estado, demostrando a tentativa do Estado brasileiro de efetivá-lo através da rede privada de ensino superior utilizando das políticas públicas do governo federal para ocupar as vagas disponíveis nessas instituições e assim garantir a efetividade do direito do cidadão. 0 recorte de estudo recai sobre o Fundo de Financiamento Estudantil (FIES) e sua recente crise de forma a compreender a importância do programa para todo o sistema de ensino superior.

Palavras-chave: Direito. Ensino Superior. Dever do Estado. FIES. 


\section{INTRODUÇÃO}

Nos últimos 20 anos, a educação superior no Brasil viveu o seu período de maior expansão no número de instituições e de matrículas. Esse fenômeno teve seu marco legal com a Constituição Federativa do Brasil de 1988 e tem uma série de documentos legais que a fundamentam e validam, como a Lei de Diretrizes e Bases da Educação, os Planos Nacionais da Educação (2001/2011 e 2014/2024), o Plano de Desenvolvimento da Educação. Estes documentos geraram Políticas Públicas Educacionais visando atingir as metas propostas, possibilitando garantir a um maior número de cidadãos o direito à Educação Superior.

A análise da importância do Fundo de Financiamento Estudantil (FIES), como política pública eficaz no objetivo de viabilizar o direito fundamental ao ensino superior, constitui o escopo desse trabalho. Inicialmente, o trabalho vai conceituar o direito à educação superior como direito fundamental e, portanto dever do Estado. Para isso, será exposto um estudo histórico e conceitual da evolução dos direitos naturais, humanos e principalmente dos direitos fundamentais. Posteriormente, o Financiamento Estudantil será contextualizado historicamente com o objetivo de destacar seus resultados e compreender a sua importância no cenário educacional brasileiro.

O tema ganha maior relevância quando inclui-se a recente crise pela qual passou o programa, ameaçando deixar milhares de pessoas sem continuar os estudos e outras impedidas de inicia-los.

Trata-se de pesquisa qualitativa que se sustentará em pesquisas documentais e na análise de dados secundários oferecidos pelos órgãos do Ministério da Educação (INEP, ENADE, Secretária de Ensino Superior, Censo do Ensino Superior).

\subsection{DEVER DO ESTADO BRASILEIRO EM VIABILIZAR O ACESSO AO ENSINO SUPERIOR}

\subsection{A EVOLUÇÃO DOS DIREITOS NA HISTÓRIA DA HUMANIDADE}

O direito à educação tem, na Constituição Brasileira de 1988, status de direito fundamental, mas nem sempre foi assim. A conquista de tal direito é histórica e transpõe fronteiras, não podendo ser considerada dádiva de legisladores e governantes. Assim, alguns conceitos são importantes para o entendimento da natureza jurídica de direito público subjetivo da qual, hoje, goza a educação.

0 direito natural é um conceito que prevê a existência de um direito que tem como fundamento a vontade de Deus (na Idade Média) e na sua evolução a própria razão humana (Idade Moderna). As concepções jus naturalistas influenciaram fortemente os modernos direitos humanos positivados. 0 direito natural pura e simplesmente positivado também não atende às necessidades de uma hermenêutica coerente que sustente os direitos fundamentais.

A moderna concepção de direitos humanos surgiu logo após a segunda guerra mundial. Segundo Flávia Piovesan (2006, p. 13), "ela é derivada do movimento de internacionalização" dos direitos em resposta as "atrocidades e horrores cometidos durante o nazismo" que trazia como projeto político a eugenia e para isso não media esforços. Foi sua marca inesquecível o descarte fácil e cruel do homem que não se encaixava no ideal ariano. A autora acrescenta "...se a $2^{\text {a }}$ Guerra Mundial significou a ruptura dos Direitos humanos, o pós guerra deveria significar sua reconstrução. (2006, p. 13)."

A Declaração dos Direitos Humanos de 1948, o documento internacional mais conhecido, regulamentou essa reconstrução. Construído num momento histórico doloroso, quando todos os direitos humanos foram violados, em seu artigo mais específico sobre o direito humano à educação privilegia a educação básica, restringindo a educação superior ao mérito. Assim diz o art. XXVI da Declaração dos Direitos Humanos:

Toda pessoa tem direito à instrução. A instrução será gratuita, pelo menos nos graus elementares e fundamentais. A instrução elementar será obrigatória. A instrução técnico-profissional será acessível a todos, bem como a instrução superior, está baseada no mérito. (ONU, 2014)

Os direitos fundamentais são os previstos na Constituição de determinado Estado. Esses possuem características bem definidas que, segundo José Afonso da Silva (2013, p. 183), são: a) historicidade surgem na Revolução Francesa e evoluem todo o tempo; b) inalienabilidade - não se pode transferi-los, negociá-los ou disponibilizá-los; c) imprescritibilidade - não prescrevem, podem ser exigidos a qualquer tempo; d) irrenunciabilidade - o indivíduo tem a prerrogativa de não usá-lo, porém, não pode renunciar a ele. 
Para Paulo Bonavides (2014, p. 383) “... não é possível compreender o constitucionalismo do Estado social brasileiro contido na carta de 1988 se fecharmos os olhos à teoria dos direitos sociais fundamentais, ao princípio da igualdade..." Com característica marcadamente histórica, os direitos fundamentais evoluem e retrocedem acompanhando a evolução da humanidade. Hoje a doutrina reconhece a existência de três gerações ou dimensões de direitos, alguns chegando a enxergar a existência de uma quarta e de uma quinta geração. Os conceitos da primeira a terceira geração já serão suficientes para o entendimento do tema.

O lema da Revolução Francesa liberdade, igualdade e fraternidade servem de parâmetro na definição das três gerações do direito: os direitos da primeira geração são os direitos civis, que; os da segunda geração são os direitos sociais que valorizam a igualdade e os da terceira geração são os direitos coletivos que buscam a fraternidade.

Os direitos de primeira geração são os chamados direitos civis, individuais e políticos e foram conquistados ainda na época da revolução burguesa. Antes os indivíduos não tinham direitos, devendo obediência ao Rei (Estado) ou ao senhor feudal. 0 reconhecimento desses direitos representa a conquista da própria subjetividade, de poder ser um indivíduo. Compõe os direitos da primeira geração direito à vida, à liberdade, à segurança, à propriedade, o direito de votar e ser votado. São, sobretudo, os direitos do indivíduo em oposição ao Estado.

Os direitos de terceira geração têm como titular o homem enquanto habitante da Terra. Sua concepção extrapola a individual e o coletivo. São despersonalizados e por isso são chamados direitos difusos. Paulo Bonavides (2014, p. 383) entende que a Carta de 1988 é uma Constituição do Estado social. Em sua concepção o Estado social brasileiro é de terceira geração, pois concede e garante os direitos sociais básicos. Para ele os direitos fundamentais são "o oxigênio das constituições democráticas" (BONAVIDES, 2014, p. 383).

A universalidade dos direitos humanos influencia e alicerça os direitos fundamentais objetivados nas Constituições dos Estados. "Atualmente, os direitos fundamentais são o parâmetro de aferição do grau de democracia de uma sociedade” (CORDEIRO, 2012, p. 28).

\subsubsection{DIREITO À EDUCAÇÃO SUPERIOR NA CONSTITUIÇÃO FEDERAL DE 1988}

A Constituição Brasileira de 1988, no dever ser, é considerada a mais completa e avançada na garantia do direito à educação no mundo (MARTINS, 2006, p. 104). Nela os direitos individuais e sociais ganham status de fundamentais, em especial o direito à educação. As questões educacionais do Brasil ganharam ênfase e atenção a partir de então “...quer considerando a educação como direito fundamental da população brasileira, quer como meio de favorecer o desenvolvimento nacional..." (SAPIO, 2010, p. 99).

Foi a primeira constituição que tratou especificamente do ensino superior, contemplando o mesmo com quatro artigos: art. 207 que confere à Universidade autonomia didático-científica, administrativa, de gestão financeira e patrimonial, além de vincularem de forma indissociável o ensino, a pesquisa e a extensão; o art. 208 inciso V que confirma o dever do Estado em efetivar acesso aos níveis mais elevados de ensino, da pesquisa e da criação artística, segundo a capacidade de cada um; o art. $213 \S 2^{\circ}$ inclui as atividades universitárias de pesquisa e extensão no rol das que podem receber apoio financeiro do poder público; e, por fim, o art. $218 \S 1^{\text {o }}$ ao $3^{\circ}$ que define de que forma o Estado irá promover e incentivar o desenvolvimento cientifico, a pesquisa e a capacitação tecnológica.

Os dispositivos constitucionais sobre a educação sofrem forte influência dos acordos e tratados assinados pelo Brasil no Direito Internacional (fruto das orientações do Banco Mundial) e está em conexão com os fundamentos da república e os princípios e valores definidos pelo legislador constituinte originário. Além de revelar o foco na universidade pesquisa.

Nina Ranieri (2000, p. 71) esclarece que apenas o art. 207, que confere à Universidade autonomia didático-científica e de gestão, tem caráter instrumental, os demais contêm um conteúdo essencialmente programático. 
Entretanto, alerta, isso não significa que o Estado pode se sentir descomprometido como o seu dever em relação ao Ensino Superior e evoca o art. 205 da mesma constituição para fundamentar sua posição:

Art. 205: A educação, direito de todos e dever do Estado da família, será promovida e incentivada com a colaboração da sociedade, visando ao pleno desenvolvimento da pessoa, seu preparo para o exercício da cidadania e sua qualificação para o trabalho. (Constituição da República Federativa do Brasil, 1988).

0 direito à educação, por ser um direito social fundamental, alcança a todos apresentando característica de universalidade. Muitos tratados e pactos internacionais chamam a atenção para a importância da educação para o desenvolvimento individual e da própria sociedade. O Pacto Internacional sobre Direitos Econômicos, Sociais e Culturais de 1966 em seu art.13, do qual o Brasil participa diz que:

Os Estados Partes do presente Pacto reconhecem o direito de toda pessoa à educação. Concordam em que a educação deverá visar o pleno desenvolvimento da personalidade humana e do sentido de sua dignidade e fortalecer o respeito pelos direitos humanos e liberdades fundamentais. Concordam ainda em que a educação deverá capacitar todas as pessoas a participar efetivamente de uma sociedade livre, favorecer a compreensão, a tolerância e a amizade entre todas as nações (...) (ONU, 2014)

\section{ENSINO SUPERIOR: DIREITO DO CIDADÃO E DEVER DO ESTADO}

Já em sua origem a Universidade agregou mestres, pensadores, entusiastas do conhecimento. É uma das principais instituições que produz, propaga e transforma o saber da sociedade. Não é a única, mas é a que em sua essência realiza essas ações com o objetivo de concentrar o conhecimento das diversas áreas, preservando e garantindo a sua transmissão à geração seguinte.

O conhecimento científico é supervalorizado, enquanto que o conhecimento autodidata ou empírico é considerado duvidoso e folclórico, com raríssimas exceções. Assim, o título universitário é condição sine qua non para a validação da capacidade profissional e do conhecimento intelectual do indivíduo. Dessa forma pode-se levantar a hipótese de que uma sociedade que não oportuniza democraticamente o acesso ao ensino superior mitigará a sua tarefa de efetivar o direito à igualdade.

Paulo Bonavides (BONAVIDES, p. 384-387) destaca, dentre os direitos fundamentais, o direito à igualdade nominando-o de direito-chave. No direito constitucional de nossos dias deixou de ser a igualdade jurídica do liberalismo para ser a igualdade material do Estado social. Para ele os direitos sociais básicos têm uma função muito importante na sociedade: "consiste pois em realizar a igualdade na sociedade; 'igualdade niveladora', volvida para situações humanas concretas, operada na esfera fática propriamente dita e não em regiões abstratas ou formais de direito." (BONAVIDES, p. 387).

Um dos principais problemas da educação superior no Brasil é que o acesso não é oportunizado de forma igualitária e só recentemente é que ações estão sendo empreendidas no sentido de democratizar e ampliar o mesmo. A política de cotas sociais, inicialmente tão combatida, atinge em cheio seu objetivo de reparação social, mesmo que ainda não contemple a necessidade de toda a sociedade. 0 Estado, então, com o compromisso de ampliar a oferta de vagas nas universidades públicas institui o Programa de Apoio a Planos de Reestruturação e Expansão das Universidades Federais (Reuni) possibilitando a criação de novos cursos e turmas, além da criação dos cursos noturnos e novas universidades no interior do país.

Se a Constituição garante legal e juridicamente uma sociedade, a educação é o único meio que assegura a operacionalização de todos os objetivos informados desde o seu preâmbulo. Então, o direito fundamental que potencializa a concretude dos demais é o acesso à educação de qualidade. A educação desenvolve o senso crítico, a consciência de si mesmo e de seus direitos e deveres, amplia a capacidade de viver em comunidade, aumenta a capacidade de realização no campo profissional, acesso à cultura, a lazer, reduz as desigualdades, aumenta a dignidade.

Carlos Rátis cita Jorge Miranda MARTINS, (2011, p. 108) e ratifica que a primeira forma de defesa dos direitos é o conhecimento do próprio direito, pois só quem conhece seus direitos pode reivindica-los e saber dos prejuízos que terá caso não os usufrua. Entendendo que a educação é meio para concretizar o princípio fundamental da dignidade da pessoa humana, causa preocupação a falta de efetividade das políticas públicas brasileiras em equilibrar a proporção entre expansão do acesso à educação e elevação da qualidade nos diversos níveis de ensino. 
Nas Constituições, a igualdade é prevista formalmente. Todos são iguais perante a lei. Cada homem é um ser único e as diferenças naturais, ideológicas são normais e saudáveis. A busca pela igualdade, que é objetivada pelo princípio constitucional, não se revela numa padronização do ser humano. E sim na redução das desigualdades econômicas e sociais que criam abismos nas condições de vida e até mesmo sobrevivência do homem.

Numa compreensão ampliada dos direitos e garantias fundamentais estes apresentam características ambivalentes, sendo geradores e redutores de custos ao mesmo tempo. (SGARBOSSA, 2014, p. 241)

É plausível sustentar que os benefícios superem os custos, como nos casos dos investimentos de recursos em educação e saúde. (...) Assim, investimentos particulares em educação são concebidos como externalidade positiva, pelo que merece internalização que os incentive (fomento, financiamento, subsídio), posto que a ausência da internalização desestimula a conduta socialmente útil. Mas são semelhantes quanto aos efeitos, pois os benefícios excedem os custos, segundo a própria literatura econômica. (SGARBOSSA, 2014, p. 239)

Considerada essencial para a dignidade da pessoa humana, a educação como dever do estado e da família, figura como primeiro direito social citado no art. 6ํㅜ, do capítulo II (direitos sociais) não deixando margem a dúvidas no que tange à intenção do legislador constituinte de elege-la como meio insubstituível para a materialização dos princípios constitucionais.“...o direito à educação, enfim, ocupa lugar central no conjunto dos direitos fundamentais, correspondente à sua importância na salvaguarda da dignidade humana: é indispensável." (RANIERI, 1988).

Apesar da lentidão do legislador infraconstitucional e da máquina estatal brasileira aos poucos as leis, planos, ações já previstas na Constituição de 1988 são implementadas: Lei de Diretrizes e Bases (LDB) em 1996, Plano Nacional da Educação em 2001/2011, Plano de Desenvolvimento da Educação em 2007, REUNI em 2007, etc. Ao estudá-los a luz da Constituição lá serão encontrados seus fundamentos e/ou previsão.

O direito ao ensino superior na constituição pode ser considerado direito fundamental, porém sua proteção é frágil (CEZNE, 2014). É necessário que seus instrumentos de proteção sejam desenvolvidos através de estudos teóricos e de sua aplicação concreta nos tribunais. As decisões dos tribunais constitucionais são de aplicação obrigatória, a jurisprudência produzida pelos mesmos é de fundamental importância na construção dos instrumentos de proteção jurídica do direito fundamental ao ensino superior. Infelizmente, no que diz respeito a esse nível de ensino as demandas judiciais são limitadas a situações administrativas, financeiras ou específicas das ações afirmativas.

O grau de eficiência do Direito será proporcional à densidade que o enunciado normativo apresentar. A análise dos direitos sociais prestacionais, revelam que estes em sua maioria possuem baixa densidade normativa (CORDEIRO, 2012, p. 53). 0 art. 208, V CF/88, artigo que trata do direito de acesso ao ensino superior, diz que o dever do Estado com a educação será efetivado com a garantia de acesso aos níveis mais elevados de ensino, da pesquisa e da criação artística, segundo a capacidade de cada um. 0 conceito de merecimento implícito nessa condição pode reduzir o alcance da norma. Essa preocupação é sintetizada na seguinte conclusão:

A forma com que cada direito fundamental é positivado tem influência direta sobre a questão da eficácia jurídica da norma que o consagra. Quanto maior a densidade normativa, maior será a força jurídica. A eficácia é o predicado que denota a capacidade da norma de produzir, em maior ou menor grau, efeitos jurídicos. Aplicabilidade envolve uma dimensão fática. (CORDEIRO, 2012, p. 51)

Comparando com os outros incisos, que dispõe sobre como o Estado efetivará seu dever com a educação nos demais níveis de ensino, percebe-se a assertividade presente, resultando numa maior densidade e instrumentalidade da norma.

O inciso I define que a educação básica será obrigatória e gratuita dos 4 (quatro) aos 17 (dezessete) anos de idade, assegurada inclusive sua oferta gratuita para todos os que a ela não tiveram acesso na idade própria. 0 legislador constituinte não deixa margens a dúvidas sobre o caráter obrigatório e gratuito do ensino básico, tornando esse um direito público subjetivo (art. 208 §1ํㅡ).

O inciso II dispõe sobre a progressiva universalização do ensino médio gratuito. Apesar de optar pela progressão não resta dúvida sobre a obrigação do Estado para com todos os cidadãos em relação ao 
Ensino médio. Os Planos Nacionais de Educação vêm implantando essa universalização. No Plano Nacional de Educação 2011/2020 o Estado assume integralmente esse dever.

$O$ inciso IV, traz uma inovação incluindo a educação infantil, em creche e pré-escola, às crianças até 5 (cinco) anos de idade obrigatória. Também vem sendo implantados através dos Planos Nacionais de Educação. A política de ir avançando na gratuidade aos poucos não deixa de ser pertinente, pois vai garantindo um nível para depois se dedicar a universalização do seguinte. É uma estratégia racional e lógica contanto que enquanto a universalização não seja possível nos níveis mais elevados, os investimentos mantenham um serviço de qualidade e acompanhem o crescimento decorrente do nível de ensino anterior.

Apesar da sua não universalidade, o direito de acesso ao ensino superior é direito público subjetivo. Mesmo sofrendo restrições por conta da conjuntura econômico-político-social, o direito de acesso continua latente aguardando mudanças na política de educação e a possibilidade de seu acesso (MARTINS, 2011, p.108-109).

a discussão em torno do direito público subjetivo do direito de acesso ao ensino superior é menosprezada pela doutrina, em face ao contraste de proteção ao ensino básico e os demais graus de ensino, não obstante não haver hierarquia entre os níveis de acesso de ensino, uma vez que o direito de acesso à educação deve ser assegurado como um todo único.(...) 0 direito subjetivo do mínimo existencial de todo e qualquer direito fundamental não está adstrito à reserva do possível; é o seu limite. Se o Estado não pode naquele momento garantir a sua concretização, por total incapacidade orçamentária, ficará, pois, em mora, até o seu imediato cumprimento. (MARTINS, 2011, p.112)

o quantum chamado de mínimo existencial é a uma quantidade mínima de certo bem que dê as pessoas condições para sua existência. 0 reconhecimento da necessidade de definição e garantia de um mínimo existencial na nossa Constituição é o início do caminho para a materialização do princípio da dignidade da pessoa humana.

O importante no ensino superior não é necessariamente a universalização, mas a igualdade de oportunidades. 0 art. 208 faz o filtro pelo mérito (há um risco de considera-lo um conceito subjetivo, inócuo servindo de desculpas ao Estado para não se comprometer objetivamente com o acesso), isso não significa a falta de obrigatoriedade do estado em garantir o acesso, antes o compromete, inclusive com os níveis anteriores, pois para conseguir efetivar o seu potencial intelectual o indivíduo deve receber uma boa formação o que significa uma escola pública de boa qualidade para que a exclusão do indivíduo ocorra apenas por falta de aptidão ou mérito e não por não poder desenvolver as suas competências intelectuais.

0 direito de acesso ao ensino superior é norma-regra constitucional auto instrumental imprescindível para a efetividade dos direitos fundamentais como um todo indissociável. Só pode haver pleno exercício da liberdade de profissão, do direito de iniciativa econômica etc., se for garantido ao cidadão acesso ao curso superior que for do seu interesse (MARTINS, 2011, p.107-108).

Supondo que todos no Brasil recebam uma educação básica com o mesmo padrão de qualidade, na idade adulta o seu desejo e aptidão é que determinaria a sua entrada no ensino superior. Para isso tem que haver vagas para todos aqueles que, por mérito, conseguirem reunir os critérios necessários para cursar o nível superior. A intenção do legislador, fundamentada nos princípios da igualdade e da dignidade da pessoa humana, era privilegiar aquele que tem a capacidade necessária para iniciar e concluir o curso superior e não promover uma competição, selecionando os melhores e criando uma minoria elitizada, pois se isso acontecer o Estado brasileiro estará ferindo os princípios que fundamentam sua constituição.

a igualdade equitativa de oportunidades significa certo conjunto de instituições que assegura oportunidades semelhantes de educação e cultura para pessoas de motivações semelhantes e que mantém cargos e posições abertos a todos, com base nas qualidades e nos esforços razoavelmente relacionados com os deveres e tarefas pertinentes. (RAWLS, 2008. p. 343)

As condições básicas para uma vida digna e direito a um mínimo existencial, não significa sobreviver, não se atem apenas aos aspectos fisiológicos da vida humana. Dignidade engloba os aspectos subjetivos do desenvolvimento humano, saúde psicológica, desenvolvimento intelectual, constituir-se cidadão. 
Segundo Rawls (2008), abaixo de certo nível de bem estar material e social, de formação e de educação, as pessoas simplesmente não podem participar da vida política e social como cidadãos iguais. Logo, a obrigação do Estado nesta seara se deve a necessidade de se assegurar a liberdade real. (CORDEIRO, 2012, p.99).

As opções feitas na Constituição de1988 dotou o cidadão brasileiro de direitos e proteções que antes ele não tinha, em contrapartida o Estado brasileiro teve que lidar com uma série de deveres custosos. No caso dos direitos sociais, a amplitude com que foram concebidos, requer uma dotação orçamentária muito superior à que antes era feita. Pode ser que os recursos não sejam suficientes para atender a todas as demandas. Segundo Karine Cordeiro (2012, p.27) “diante desses entraves, por vezes incontornáveis, o mínimo existencial passa a atuar como protagonista na garantia dos níveis essenciais das prestações sociais ligadas à dignidade da pessoa humana".

Quanto mais se amplia os direitos educacionais, mais recursos são necessários para garantir a aplicabilidade da norma sem abrir mão da qualidade. Bobbio se revela insatisfeito com a inflação de Direitos sem garantias, entendendo o mesmo como um problema político e não filosófico, em que "o problema filosófico dos direitos do homem não pode ser dissociado do estudo dos problemas históricos, sociais, econômicos, psicológicos, inerentes a sua realização: o problema dos fins não pode ser dissociado do problema dos meios." (BOBBIO, 2004, p. 24).

O desafio hoje não é garantir o reconhecimento do direito à educação e sua importância na efetivação dos princípios fundamentadores da constituição. O grande desafio do Estado brasileiro é efetivá-lo com a qualidade exigida constitucionalmente. Os recursos financeiros já estão previstos na Constituição. 0 art. 212 prevê que a União aplicará no mínimo 18\%, os Estados, Distrito Federal e Municípios no mínimo $25 \%$ da receita resultante de impostos na manutenção e desenvolvimento do ensino. As normas são abundantes, mas os recursos ainda são escassos tendo em vista que o direito à educação será realmente materializado quando forem atingidos os preceitos da obrigatoriedade, qualidade e gratuidade previstos na constituição. É importante que o Estado brasileiro planeje suas políticas públicas observando a conjuntura socioeconômica sem perder de vista sua obrigação de atender a esse direito fundamental.

Se nem todos os direitos econômicos, sociais e culturais puderem ser tornados plenamente operativos em certo momento ou para todas as pessoas, então haverá que determinar com que prioridade e em que medida o deverão ser. 0 contrário redundaria na inutilização dos comandos constitucionais: querer fazer tudo ao mesmo tempo e nada conseguir fazer. (MARTINS, 2011, p. 111).

Direitos fundamentais geram deveres fundamentais (MARTINS, 2011, p. 111). É dever do Estado oferecer a satisfação adequada dos direitos fundamentais. Satisfação adequada, no caso do direito de acesso ao ensino superior inclui a oferta de cursos da melhor qualidade possível (MARTINS, 2011, p. 111), assim como democratizar as oportunidades profissionais para que o sujeito tenha uma formação que o coloque em condições de igualdade com os demais.

Ciente do seu dever constitucional e comprometido com os acordos e tratados internacionais dos quais é signatário, o Estado brasileiro busca através de políticas públicas e programas de governo diminuir o seu déficit quantitativo e qualitativo em relação à educação.

\section{CONTRIBUIÇÃO DO FIES NA EFETIVAÇÃO DO DIREITO FUNDAMENTAL À EDUCAÇÃO}

\subsection{CRÉDITO EDUCATIVO}

Sendo o direito à educação um dos direitos fundamentais, que deve ter seu gozo garantido pelo estado, espera-se que o mesmo imprima ações positivas que assegurem ao cidadão a possibilidade de usufruir desse direito. Essas ações positivas ocorrem através das políticas públicas educacionais.

0 acesso ao direito a educação será possível através da implementação de políticas públicas, as quais se constituem em mecanismos de ação do Estado com o objetivo de garantir a todos os direitos fundamentais consagrados em nossa carta magna, é através da implementação de políticas públicas que o direito à educação será assegurado. (MOURA, 2014, p. 6) 
Após a Lei de Diretrizes e Bases da Educação de 1996, as políticas de expansão e democratização da educação superior beneficiaram milhares de cidadãos. Dentre as políticas implementadas pós LDB, o foco de estudo é o Fundo de Financiamento Estudantil. Analise da sua gênese, implementação, evolução e importância que foi alcançando na efetivação desse direito, no intuito de entender a atual crise pela qual passa o FIES e a reação da sociedade a possibilidade de encolhimento de sua atuação ou até mesmo de sua falência.

O Financiamento Estudantil no Brasil surgiu no ano de 1975 quando foi criado o primeiro programa com esse objetivo - 0 Programa de Crédito Educativo (CREDUC). 0 objetivo era disponibilizar empréstimos para que estudantes interessados pudessem realizar seus estudos em IES privadas, além de possibilitar o custeio de despesas necessárias durante sua formação universitária (BORGES, 2012, p. 34).

O estudante aprovado para o financiamento só iria iniciar o pagamento após a conclusão do curso e tinha a quantidade de anos que durou sua graduação acrescidos de mais um ano para quitar o financiamento. Sobre o valor financiado incidia uma correção de $15 \%$ ao ano. Os recursos do programa vinham do Ministério da Educação, da Caixa Econômica Federal e do Banco do Brasil e bancos comerciais também poderiam ser agentes financiadores do programa, usando recursos de depósitos compulsórios feitos ao Banco Central que liberava até 1\% desse recurso para esse fim (BORGES, 2012, p. 34).

0 índice de inadimplência do programa chegou a 50\%, ocasionando a saída dos bancos privados e do BB do programa em 1983. Os recursos passaram a vir exclusivamente do Ministério da Educação e da Caixa Econômica Federal. Ainda nesse mesmo ano, o CREDUC passou a contar com recursos do MEC e do FAS (Fundo de Apoio ao Desenvolvimento Social).

Assim, em 1999 o programa sofreu sérios riscos de ser desativado, pois sofria com a inadimplência e a inflação que assolava a economia brasileira, comprometendo a sua viabilidade financeira. Sobreviveu até 1998 com modificações em 1992 e 1994, ampliando as fontes de recursos através dos concursos da Caixa Econômica Federal e impondo condições de excelência acadêmica e carência financeira do aluno. Porém, a inadimplência sempre presente e a ineficiência na aplicação dos recursos (apenas 63,5\% dos recursos eram utilizados devido aos entraves burocráticos impostos ao processo) o empurraram para o fim (BORGES, 2012, p. 34-35).

\subsubsection{FUNDO DE FINANCIAMENTO ESTUDANTIL}

Em 1999 é criado o Fundo de Financiamento Estudantil (FIES), um programa que também visava financiar os estudos de estudantes carentes em Instituições de Ensino Superior Privadas. Criado pela Mediada Provisória 1827/99, lei 10.260/2001 e regulamentado pelas Portarias Ministeriais no 860/99 e 1386/99, além da Resolução CMN 2647/99.

No 1ํ PNE (2001/2010), a meta era: 1. Prover, até o final da década, a oferta de educação superior para, pelo menos, $30 \%$ da faixa etária de 18 a 24 anos. Com as políticas de expansão e democratização das vagas, uma outra faixa de estudante (acima de 24 anos) foi mobilizada dividindo os recursos com os alunos que saíram do ensino médio. A taxa líquida (RISTOFF, 2013, p. 3) ficou em torno de 9\%. No 2을 PNE (2014/2014), a meta ficou ainda mais desafiadora: elevação de forma qualificada da taxa bruta de matrícula na educação superior para 50\% e a taxa líquida para 33\% da população de 18 a 24 anos.

Em 2014, as instituições privadas contaram com 5,3 milhões de alunos, segundo o Censo de Educação Superior de 2013. Foram 1,9 milhões de estudantes com financiamento pelo FIES, esse número correspondeu a 35\% do total de alunos das instituições privadas. Comparando com o número de alunos total no ensino superior (pública e privada) que foram de 7,3 milhões o FIES atendeu a $26 \%$ de todos os alunos do ensino superior (PRESTAÇÃO DE CONTAS ORDINÁRIAS ANUAL, 2014, p. 22). Tornando um dado real a importante participação do Fies no acesso e permanência na educação superior.

\subsubsection{NOVO FIES}

O novo programa de financiamento estudantil vem com um discurso de valorização da qualidade do ensino superior. Impôs como condição para o aluno se inscrever no programa que o mesmo estivesse matriculado em cursos nas instituições que obtivessem avaliação positiva do MEC, entendendo-se como avaliação positiva no mínimo a nota 3. 
Esta condicionante tem como objetivo o incentivo para as instituições de ensino superior, participantes do programa ou com interesse em participar, a realizar investimentos na sua infraestrutura, em melhores condições de trabalho, na qualificação do pessoal docente e, consequentemente, no seu projeto pedagógico.

O crescimento exponencial do FIES aponta para a necessidade do governo Federal estabelecer metas cada vez mais rígidas para as IES e seus cursos, seja com avaliações internas por meio de Comissões Próprias de Avaliação (CPA) ou pelas avaliações externas como o ENADE. Mecanismos de controle sobre a prestação de serviços ao aluno são necessários, pois quanto maior o número de alunos com financiamento, maior será a responsabilidade do governo sobre a garantia da qualidade da formação acadêmica que as IES propõem e dispõem aos alunos. Senão o governo Federal será apenas um fomentador da captação de alunos para as IES, gerando lucro certo e esforço mínimo. (PINHEIRO, 2013, p. 12).

No primeiro momento o FIES só poderia ser solicitado pelo estudante no início do seu curso e deveria financiar $100 \%$ do mesmo. Em 2005, o FIES sofre as primeiras mudanças, visando seu aprimoramento. A oferta do programa é ampliada para os alunos já contemplados com o Programa Universidade para Todos ${ }^{11}$ em $50 \%$, podendo, então, financiar os outros $50 \%$.

Em 2010, as Portarias Normativas no 10, 18 trazem novidades: o programa passa a ser operado pelo Fundo Nacional de Desenvolvimento da Educação (FNDE); o aluno pode solicitar o financiamento a qualquer tempo de seu curso (ampliando bastante o âmbito de atuação do programa); e a liberação da condição que mais entraves causava aos contratos, a exigência de fiador para os estudantes de licenciatura, para os que possuem uma renda familiar bruta de até 1 salário mínimo e meio e para quem tem bolsa parcial do PROUNI (BORGES, 2012, p.39 e 40).

Se mantem o critério da meritocracia das Instituições participantes do programa. Portanto, o estudante deve estar matriculado em instituições com conceito 3 no Sistema Nacional de Avaliação da Educação Superior (SINAES) em cursos presenciais. O programa financia de $50 \%$ a $100 \%$ do curso com juros de 3,4\% ao ano. São agentes financeiros o Banco de Brasil e a Caixa, e o período de pagamento para o estudante é de até três vezes o período do curso, com carência de dezoito meses.

A grande novidade é a Fiança Solidária que é uma garantia oferecida entre estudantes que tem financiamento. Os alunos são reunidos numa espécie de cooperativa de crédito (MONTEIRO, 2012, p.17) em que são formados grupos de 3 a 5 estudantes candidatos ao financiamento e eles serão todos fiadores de cada um individualmente, é a criação do Fundo de Garantia de Operações de Crédito Educativo (FGEDUC). Esses grupos são criados pelo próprio agente financeiro no momento da contratação.

A partir do segundo semestre de 2011, outra condição se impôs ao candidato ao financiamento: teria que ter se submetido ao Exame Nacional do Ensino Médio (ENEM), a exceções seriam para professor da rede pública da educação básica em cursos de licenciatura, normal superior ou pedagogia.

As instituições podem escolher entre isenções fiscais ou receber verbas do MEC. 0 repasse às instituições é mensal em Certificados Financeiros do Tesouro (CFT-E). As entidades vêm sinalizando, desde 2007 para os atrasos cada vez maiores nesses repasses, já como um prenúncio de que o orçamento do FIES sofria revezes (MONTEIRO, 2012, p.17).

Em 2010, o Fundo Nacional do Desenvolvimento da Educação assumiu o papel de agente operador do FIES. As mudanças no FIES tem como principal objetivo ampliar e melhorar as condições e possibilidades de financiamento para os estudantes, otimizando o uso dos recursos disponibilizados. Outro objetivo é incentivar a escolha por cursos considerados de extrema importância para o desenvolvimento do país: licenciatura e medicina, através da possibilidade desses estudantes depois de formados prestarem serviços na rede pública de ensino e de saúde para abaterem dos valores do seu financiamento.

Também é objetivo das inovações da Lei 12.202/2010 promover a integração das duas principais políticas educacionais voltadas para o acesso e democratização das vagas no ensino superior, o PROUNI e o FIES. É

11 PROUNI- Programa de extrema importância na política de expansão e democratização do ensino superior do Governo Federal foi criado em 2004 pela Lei 11.096 de 13 de janeiro de 2005 com o objetivo de oferecer bolsas de estudo parciais e integrais em cursos superiores de IES particulares que aderirem ao programa em troca de benefícios fiscais 
assegurado ao bolsista parcial do PROUNI o financiamento dos outros 50\%, mesmo que a instituição em que estuda já tenha atingido o seu limite, além da mitigação da fiança ao ter direito em optar pela Fiança Solidária. Outra vantagem que o bolsista parcial do Prouni tem em relação aos outros estudantes financiados, é que se ele optar pela fiança convencional o seu fiador deve possuir renda mensal bruta mínima de valor igual à parcela mensal da semestralidade, enquanto os fiadores dos demais tem a condição de possuir renda mensal bruta igual ao dobro da parcela mensal da semestralidade. Essas medidas visavam diminuir a evasão dos bolsistas parciais do PROUNI, garantindo o financiamento dos recursos necessários para a conclusão de sua formação.

A Portaria Normativa no 23 de 20 de novembro de 2013 flexibilizou a continuidade do financiamento em caso de aproveitamento inferior a $75 \%$ das disciplinas cursadas pelo estudante no último semestre financiado pelo FIES em até duas vezes, excepcionalmente e justificando o fato. Antes a regra permitia até uma vez.

Todas essas flexibilizações e desburocratizações fez a contratação do financiamento aumentar exponencialmente (tabela no 01). É uma política pública focalizada que visa atender aos estudantes carentes, controlando as variáveis determinantes de evasão e não matrícula no ensino superior. É uma forma de reduzir, em última instancia, o abismo entre as classes sociais, possibilitando através da formação mais qualificada o acesso a níveis salariais e sociais mais elevados.

Tabela de contratos novos assinados

\begin{tabular}{|c|c|c|}
\hline \multirow{2}{*}{ Ano } & $\begin{array}{c}\text { Quantidade de contratos novos } \\
\text { \% de aumento em relação ao ano } \\
\text { anterior }\end{array}$ \\
\hline 2009 & 32.000 & - \\
\hline 2010 & 71.000 & $125 \%$ \\
\hline 2011 & 149.000 & $108 \%$ \\
\hline 2012 & 372.000 & $150 \%$ \\
\hline 2013 & 552.000 & $48,5 \%$ \\
\hline 2014 & 720.000 & $34,5 \%$ \\
\hline
\end{tabular}

Fonte: FNDE

As novas condições, bem mais fáceis de atender, fez o FIES se expandir vertiginosamente. É clara a vinculação entre as mudanças no programa e as metas do PNE a serem alcançadas. Nos primeiros três anos o acréscimo fez o número de contratos dobrar ano a ano, sinal de demanda reprimida pelas rígidas regras que excluíam muitos estudantes que em seu estado de carência financeira não conseguiam se beneficiar de um programa feito para lhe atender. Porém, esse crescimento se deu em troca das regras que poderiam dar uma maior segurança no adimplemento dos contratos. 0 que pode comprometer a viabilidade do programa.

O ano de 2015 viu chegar a crise no FIES. O Brasil vive uma crise econômica e política que afeta diretamente o governo e em consequência suas políticas públicas. A educação sofreu vários cortes no seu orçamento e o FIES teve ameaçada a possibilidade de novos contratos, até mesmo de aditamentos.

\subsection{PROGRAMAÇÃO ORÇAMENTÁRIA E FINANCEIRA}

Na análise do Relatório de Gestão do FIES Exercício 2014, se percebe uma diferença abissal entre a dotação prevista inicialmente para o programa e a dotação final.

A lei orçamentária de 2014 tem uma dotação inicial de $\mathrm{R} \$ 1.527 .097 .593,00$, valor previsto para 151.501 estudantes financiados. Porém, o número de contratos a serem efetivamente pagos era de 1.900.343 formalizados após 2010 e administrados pelo FNDE e mais 10.375 formalizados antes de 2010 e administrados pela Caixa Econômica Federal. Dessa forma os números reais de 2014 são 1.910 .718 estudantes financiados com uma dotação final de 12.132.517.111,00.

Nesse documento justifica-se a diferença entre o crédito inicial e final pelo fato dos financiamentos estudantis terem características plurianuais. 0 que é da natureza do contrato. Então, a previsão orçamentária já deveria prever o valor real necessário para atender ao programa, evitando a solicitação de crédito suplementar, o que na verdade sugere um orçamento aberto para o programa, o que pode trazer consequências de insegurança e inviabilidade. 


\section{CONSIDERAÇÕES FINAIS}

O FIES é um programa de inclusão social e fundamental para a garantia da efetivação do direito fundamental à Educação, beneficia o estudante carente e ainda alcança um benefício não previsto que é possibilitar o estudo nos níveis superiores de pessoas fora da faixa etária regular, gerando a possibilidade de ascensão e melhoria da qualidade de vida a um público que não era alvo desse programa.

Preocupa o possível uso eleitoreiro do programa, já que as principais modificações liberalizantes de popularização do sistema foram realizadas nos anos anteriores à eleição para presidência da república ou no próprio ano de eleição: início 2010 (Dilma Roussef foi eleita para o primeiro mandato) e final de 2013 para implementação em 2014 (reeleição de Dilma Roussef).

Política Pública Educacional tem papel fundamental para o futuro do país e o possível uso para situações pontuais e de interesse não coletivo, deve ser rechaçado. É importante garantir e estabilizar as conquistas para depois ampliá-las para não colocar em risco a efetivação do Plano Nacional de Educação. A falta de um orçamento coerente com os gastos coloca o programa numa situação de fragilidade. A própria operação do financiamento se mostra não atrativa para bancos comerciais demonstrando que não é uma atividade econômica lucrativa. Recursos financeiros não são inesgotáveis e na área social tem-se que ser usados com objetividade e responsabilidade.

Apesar das políticas recentes para ampliação e acesso ao ensino superior, o número de brasileiros que alcançam e concluem esse nível de ensino ainda é muito pequeno. Por isso, é importante tratar as políticas públicas educacionais como prioridade e muita responsabilidade, principalmente aquelas que atingem resultados tão significativos como o FIES.

\section{REFERÊNCIAS}

[1] Bobbio, Norberto. A era dos direitos. Tradução: Carlos Nelson Coutinho. Rio de Janeiro: Ed. Elsevier. 2004.

[2] Bonavides, Paulo. Curso de Direito Constitucional. São Paulo: Ed. Melhoramentos, 2014.

[3] Borges, Francisco C. D. B. Financiamento Público e ampliação do acesso ao ensino superior no Brasil: Repercussões em instituições particulares de ensino; Dissertação (mestrado). São Paulo: Universidade da Cidade de São Paulo, 2012.

[4] Brasil. Constituição da República Federativa do Brasil: texto constitucional promulgado em 5 de outubro de 1988, com as alterações determinadas pelas Emendas Constitucionais de Revisão no 1 a 6/94pelas Emendas Constitucionais no 1/92 a73/1993 e pelo Decreto Legislativo no 186/2008. Brasília: Senado Federal, Coordenação de Edições Técnicas, 2013.

[5] Cezne, Andrea N. O Direito à Educação superior na Constituição Federal de 1988 como direito fundamental. http://www.redalyc.org/pdf/1171/11711 7257009.pdf. Acesso em: 09 out. 2014

[6] Cordeiro, Karine da Silva. Direitos Fundamentais Sociais: Dignidade da Pessoa Humana e Mínimo existencial. O papel do Poder Judiciário. Porto Alegre: Livraria do Advogado Editora, 2012.

[7] Martins, Carlos E. B. R. O Direito fundamental de acesso ao Ensino Superior: "A Estatização das vagas nas Universidades Particulares. In: Homem, António Pedro Barbas(Org.). Temas de Direito à Educação. Coimbra: Edições Almedina, 2006.

[8] _ Introdução ao Estudo sobre os deveres fundamentais. Salvador: Editora da Faculdade Baiana de Direito. 2011.

[9] Monteiro, Afonso Celso. A viabilidade financeira do Fundo de Financiamento ao Estudante de Ensino Superior - Fies para a Instituição Privada. Monografia de Especialização. Curitiba: Universidade Tecnológica Federal do Paraná, 2012.

[10] Moura, Daiana M. de. Políticas Públicas Educacionais Prouni e Fies: Democratização do acesso ao ensino Superior. In.: Anais do XI Seminário Internacional de Demandas Sociais e Políticas Públicas na Sociedade Contemporânea. VII Mostra de Trabalhos Jurídicos Científicos. 2014

[11] ONU. Declaração Universal dos Direitos Humanos. <http://www.dudh.org.br/declaracao/> Acesso em: 16 out. 2014.

[12] ONU. Pacto Internacional sobre Direitos Econômicos, Sociais e Culturais. http://www.dhnet.org.br/direitos/sip/onu/doc/pacto1.htm. Acesso em: 16 out. 2014.

[13] Pinheiro, Wesley M. Captação X Inclusão: duas faces do financiamento estudantil. Revista Espaço Acadêmico. São Paulo: no 149, out. 2013.

[14] Piovesan, Flávia- Concepção Contemporânea de direitos humanos. In: HADDAD, Sérgio; GRACIANO, Mariângela(orgs). A educação entre os direitos humanos. Campinas: Autores Associados. São Paulo: Ação Educativa, 2006.

[15] Ranieri, Nina B. S. Educação Superior, Direito e Estado na Lei de Diretrizes e Bases (Lei 9394/96). São Paulo: Editora da Universidade de São Paulo, 2000.

[16] _ 0 regime jurídico do Direito à Educação na Constituição Brasileira de 1988. <http://nupps.usp.br/downloads/artigos/ninaranieri/jurisstf.pdf>. Acesso em: 17 jun. 2014. 
[17] Rawls, John. Uma teoria da Justiça. Tradução Jussara Simões. 3 ed. São Paulo: Ed. Martins Fontes, 2008.

[18] Ristoff, Dilvo. Vinte e um anos de Educação Superior: Expansão e Democratização. In.: Cadernos do GEA no 3 ; Janeiro - junho. São Paulo, 2013.

[19] Prestação de contas ordinárias anual - Relatório de Gestão do Exercício de 2014; Fundo de Financiamento Infantil. Ministério da Educação; Secretaria de Educação Superior; Fundo de Financiamento Estudantil. 2014.

[20] Sapio, Gabriele. A Educação no Brasil e o princípio da dignidade da pessoa humana. São Paulo: Ed. Ícone. 2010.

[21] Silva, José A. da. Curso de Direito Constitucional Positivo. 36º edição. São Paulo-SP. Malheiros Editora. 2013. 


\section{Capítulo 17}

\section{A escola no território das cidades: As condições de moradia e suas implicações no descumprimento do programa bolsa família (PBF)}

\section{Celyane Souza dos Santos}

Caio César Gomes de Moura

Gisele Alves Xavier da Silva

Robéria Viana Correia de Souza

Edna Tânia Ferreira da Silva

Resumo: 0 estudo desenvolveu-se na escola Nazinha Barbosa da Franca, localizada no Bairro de Manaíra, em João Pessoa-PB. A escola atende as crianças e aos adolescentes moradoras do Bairro São José, integrando a maior parte dos estudantes. tem como objetivo discutir e analisar as problemáticas urbanas que incidem no descumprimento das condicionalidades do Programa Bolsa Família (PBF) na educação, na perspectiva de compreender e intervir sobre a questão da infrequência e permanência de crianças e adolescentes na escola, visando a garantia de direitos, aliado ao fortalecimento de vínculos dos indivíduos e suas famílias com a escola e com a sociedade, a fim de que tenham acesso a educação e à proteção social. Procedeu-se mediante o acompanhamento, mapeamento e monitoramento dos alunos e suas famílias, que estão em descumprimento ao beneficio na referida escola, complementado através de revisão bibliográfica. Desse modo, no processo da intervenção na escola, no acompanhamento das famílias, possibilitou levantar expressões da questão urbana que interferem no descumprimento do PBF, no caso na infrequência e evasão na escola. Logo, neste trabalho, foi problematizado às condições ambientais presentes no território e de infra-estrutura e serviços em que se insere o Bairro São José, que impactam no deslocamento e no acesso difícil à escola pelos seus moradores e no conseqüente descumprimento à condicionalidade exigida na Política de Assistência Social. 0 Bairro São José, paradoxalmente, não está distante da escola, em periferias longínquas, mas tem uma história associada à ocupação ribeirinha, subequipado e "apartado" do tecido urbano, com condições precárias de urbanidade e de pobreza absoluta. Observa-se, contudo, que a questão do "direito à cidade" para as classes de baixa renda não se resume somente à questão quanto à localização sócio-territorial, no caso, distante dos espaços bem equipados da cidade, embora a periferização seja uma marca dos conjuntos habitacionais construídos. A inexistência de urbanidade impede a circulação em outros bairros, agrava a precariedade e torna ainda mais difícil o acesso dos moradores aos serviços e benefícios.

Palavras-chave: Território, Escola, Assistência Social, Urbanização. 


\section{INTRODUÇÃO}

0 presente trabalho trata-se de um desdobramento parcial referente a sistematização da experiência de extensão, do curso de Serviço Social/UFPB, realizada na Escola Municipal "Nazinha Barbosa da Franca", situada no bairro Manaíra, em João Pessoa-PB, vinculada a intervenção acerca do descumprimento das condicionalidades do Programa Bolsa Família (PBF) na educação. A escola atende as crianças e aos adolescentes moradoras do Bairro São José, integrando a maior parte dos estudantes.

0 estudo tem como objetivo discutir e analisar as problemáticas urbanas que incidem no descumprimento das condicionalidades do PBF na educação, na perspectiva de compreender e intervir sobre a questão da frequência e permanência de crianças e adolescentes na escola, visando a garantia de direitos, aliado ao fortalecimento de vínculos dos indivíduos e suas famílias com a escola e com a sociedade, a fim de que tenham acesso a educação e à proteção social. 0 estudo procedeu-se mediante o acompanhamento, mapeamento e monitoramento dos alunos e suas famílias, que estão em descumprimento ao beneficio na referida escola.

Desse modo, no processo da intervenção na escola, no acompanhamento das famílias, possibilitou levantar expressões da questão urbana que interferem no descumprimento do PBF, no caso na infrequência e evasão na escola.

Logo, neste trabalho, será problematizado às condições ambientais presentes no território e de infraestrutura e serviços em que se insere o bairro São José, que impactam no deslocamento e no acesso difícil à escola pelos seus moradores. 0 Bairro São José foi construído em região de manguezal às margens do Rio Jaguaribe. A escola se situa nas proximidades do bairro, no entanto, contraditoriamente está localizada no Bairro de Manaíra, de classe média alta com infraestrutura, equipamentos e serviços ofertados na cidade.

Trata-se do modo de inserção de populações nas cidades no Brasil, caracterizadas nas suas desigualdades de renda, de classes e de qualidade de vida dos seus moradores.

Uma característica comum a todas as cidades brasileiras, independentemente de sua região, história, economia ou tamanho, é o fato de cada uma delas apresentar um contraste muito claro entre uma parte da cidade que possui alguma condição de urbanidade, uma porção pavimentada, ajardinada e arborizada, com infra-estrutura completa - independente da qualidade desses elementos, que em geral é pouca - e outra parte, normalmente de duas a três vezes maior do que a primeira cuja infra-estrutura é incompleta, o urbanismo inexiste, que se aproxima mais da idéia de um acampamento do que propriamente de uma cidade.

[...] na ocupação precária do mangue em contraposição à alta qualidade dos bairros da orla, em muitas cidades de beira-mar; na eterna linha divisória entre o morro e o asfalto no Rio, e em muitas outras variantes dessa cisão das nossas cidades que se repete permanentemente em nossa história e geografia urbana. (ROLNIK, 2002, p.54)

O Bairro São José, paradoxalmente, não está distante da escola, em periferias longínquas, mas tem uma história associada à ocupação ribeirinha, subequipado e "apartado" do tecido urbano, com condições precárias de urbanidade e de pobreza absoluta. Observa-se, contudo, que a questão do "direito à cidade" para as classes de baixa renda não se resume somente à questão quanto à localização sócio-territorial, no caso, distante dos espaços bem equipados da cidade, embora a periferização seja uma marca dos conjuntos habitacionais construídos. A inexistência de urbanidade impede a circulação em outros bairros, agrava a precariedade e torna ainda mais difícil o acesso dos moradores aos serviços e benefícios.

Para os moradores do Bairro São José, principalmente nos meses de inverno, quando no Nordeste, especificamente em João Pessoa, têm-se fortes chuvas, ocorre a dificuldade das crianças e adolescentes do bairro acessarem a escola.

Assim, a territorialidade, bem como, a não integralidade entre as políticas da habitação, da educação, da saúde e da assistência social, entre outras interferem no cumprimento das condicionalidades do PBF.

\section{METODOLOGIA}

0 estudo procedeu-se mediante o acompanhamento, mapeamento e monitoramento dos alunos, do $1^{\mathrm{o}}$ ao 9o ano, e suas famílias, na Escola Nazinha Barbosa da Franca, que estão em descumprimento ao Programa Bolsa Família (PBF) na Escola. Realizou-se levantamento quantitativo de alunos em descumprimento do PBF através da freqüência escolar nos turnos da manhã e da tarde, visita domiciliar, oficinas e reuniões. 
Contudo, esta experiência de intervenção é complementada através de pesquisa bibliográfica, mediante consulta a dados secundários publicizados em livros, revistas, artigos, dissertações de mestrado e sites. No processo de análise dos dados, buscou-se com base em referencial teórico-crítico fundamentar o objeto de estudo, na perspectiva de compreendê-lo em sua totalidade, formulando categorias temáticas para explicar as contradições e paradoxos que emergem do real.

Desse modo, possibilitou levantar expressões da questão urbana que interferem no descumprimento do PBF, na infrequência e evasão na escola.

\section{RESULTADOS E DISCUSSÃO}

A experiência da pobreza marca de forma permanente as cidades no Brasil, ao passo em que traz em seu rastro situações de riscos e vulnerabilidades sociais de grandes contingentes de trabalhadores. São famílias que vivenciam um conjunto de desproteções, privações e necessidades, uma pobreza cotidiana absoluta, dado às condições aviltantes de sobrevivência.

Fato que explica-se em decorrência não somente da multifatorialidade das necessidades sociais decorrentes de privações de trabalho, de renda, como pela ausente universalidade de presença e/ou precariedade de equipamentos sociais urbanos nos lugares onde vive a população, como é o caso das escolas nos bairros pobres das cidades.

A cidade é dividida em função das classes sociais e da divisão social do trabalho e a pobreza está confinada nos territórios. Encontramos imensas diferenças de acesso aos serviços sociais nas cidades, como é o caso da educação, uma verdadeira "exclusão territorial". De acordo com Rolnik (2002),

0 quadro de contraposição entre uma minoria qualificada e uma maioria com condições urbanísticas precárias relaciona-se a todas as formas de desigualdades, correspondendo a uma situação de exclusão territorial. Essa situação de exclusão é muito mais do que a expressão da desigualdade de renda e das desigualdades sociais: é agente de reprodução dessa desigualdade. Em uma cidade dividida entre a porção legal, rica e com infra-estrutura e a ilegal, pobre e precária, a população que está em situação desfavorável acaba tendo muito pouco acesso a oportunidades de trabalho, cultura ou lazer. Simetricamente, as oportunidades de crescimento circulam nos meios daqueles que já vivem melhor, pois a sobreposição das diversas dimensões da exclusão incidindo sobre a mesma população fazem com que a permeabilidade entre as duas partes seja muito pequena. (2002, p. 54-55)

Desse modo, o direito à cidade e imerso nela o direito à moradia, a assistência social e ao acesso aos serviços de educação, uma forma particular de materialização do direito à cidade, se dá num contexto contraditório de classes e profundamente desigual, de leis avançadas na institucionalização de instrumentos de gestão urbana, qualificados de democráticos, mas de manutenção dos processos de apropriação privada da terra, de precarização da força de trabalho e de degradação de recursos ambientais.

Assim o direito à cidade, ao que ela oferece em termos de equipamentos sociais, não é acessível à população de bairros de baixa renda, como é o caso do Bairro São José, mesmo apresentando como peculiaridade o fato de está localizado nas proximidades de Manaíra que é um bairro de classe média alta, em João Pessoa- PB.

Os moradores do Bairro São José estão situados nas menores faixas de renda e são desempregados, trabalhadores dos serviços domésticos, aposentados, vendedores ambulantes,biscateiros, catadores de material reciclável, ajudantes da construção civil, eletricistas, garçons, pescadores, trabalhadores de cargas e descargas de mercadorias, guardadores de carros, pedintes, agentes comunitários, e outros, e grande parte da população sem vínculo empregatício e direitos trabalhistas. De uma maneira geral, observa-se que a composição da renda dos moradores do bairro indica uma participação expressiva nos programas de assistência social, com destaque para a renda do Programa Bolsa Família.

Os dados de renda se reflete na escolaridade, com grande percentual de pessoas que não estudaram e que não conseguem manter os filhos na escola, como é o caso do descumprimento a condicionalidade da educação do PBF, e os motivos encontrados é a dificuldade de acesso e de manter-se na escola. 0 bairro São José e a Escola "Nazinha Barbosa da Franca", é expressão dessa realidade. 
Por volta da década 1970, consequência de um intenso processo migratório, em especial causado pelas transformações na organização da produção no campo, secas prolongadas no Sertão, Borborema e no Agreste e as desigualdades sociais presentes na cidade - baixos salários, subemprego e desemprego surgiram às primeiras comunidades na cidade de João Pessoa. 0 Bairro São José, que como já afirmado, encontra-se a beira do Rio Jaguaribe, local que com muita frequência é citado em manchetes dos principais jornais do Estado da Paraíba.

Em geral, a população de baixa renda só tem a possibilidade de ocupar terras periféricas - muito mais baratas porque em geral não têm nenhuma infraestrutura - e construir aos poucos suas casas. Ou ocupar áreas ambientalmente frágeis, que teoricamente não poderiam ser urbanizadas. [...] E quando as ocupações das áreas frágeis ou estratégicas do ponto de vista ambiental provoca as enchentes ou a erosão, é evidente que quem vai sofrer mais é o habitante desses locais, mas as enchentes, a contaminação dos mananciais, os processos erosivos mais dramáticos atingem a cidade como um todo. (ROLNIK, 2002, p 55)

Registro publicizados em diversos estudos indicam que a encosta do Rio Jaguaribe começou a ser ocupada nos anos de 1970 e acelerada em 1980. Os ocupantes começaram a construir moradias nos terrenos de maior salubridade, menor proximidade do rio, locais que estavam aptos para o plantio de roças e criação de animais. A comunidade São José foi ocupada nesse período. Araújo afirma que,

O espaço que até então se podia dizer harmonioso, com o crescimento acelerado a cada década já podia se observar o surgimento de problemas agravados pelas ocupações que, aos poucos, comprometiam as condições sanitárias e de habitabilidade na área, tanto pela falta de esgotamento sanitário, como pela poluição do rio causada pelo número muito grande de pessoas que em 1983, chegou a atingir aproximadamente 6.000 habitantes. (ARAUJO, 2007, p.21)

De acordo com Cortez (1999, p. 124), o bairro São José tem um histórico de ocupações de moradores de diversas localidades, alguns de outros bairros ou comunidades da cidade João Pessoa, outros de áreas um pouco mais distantes, dos municípios que compõem a mesorregião Agreste, Borborema e Sertão, expulsos pela seca, pela falta de emprego e com o objetivo da conquista de trabalho e de moradia na cidade grande.

É importante salientar que nesse contexto de formação do bairro São José, a cidade de João Pessoa encontrava-se em um processo de alterações em sua dinâmica sócio ocupacional. 0 mercado especulativo imobiliário investia nos centros urbanos, nisso operava-se uma expulsão da classe pobre para áreas afastadas dessas novas centralidades, em áreas insalubres e de risco ambiental. Essa dinâmica de produção do espaço faz crescer a desigualdade e a segregação sócioespacial.

Para permanecer na cidade, o homem expulso do campo e de dentro da própria cidade, procura os espaços em áreas de várzeas e de encostas, bem como ocorreu com os moradores do Bairro São José que lá estão por meio de um processo de ocupação.

Os principais condicionantes do seu surgimento foram a localização próxima dos bairros de Manaíra e Tambaú, que começavam a ganhar feições de bairros de classe média-alta, atraentes para absorver uma mão-de-obra menos qualificada como de vigia, jardineiro, empregos domésticos, e um mercado da construção civil em crescimento, favorável para pedreiros, serventes, encanadores, eletricistas etc. (LIMA; HUGO, 2013)

Ao passo que se intensificou a urbanização nas redondezas da comunidade, nesse caso, a impermeabilização do solo e alterações no curso do rio Jaguaribe para investimentos urbanos, a área se tornou susceptível ao desencadeamento de enchentes provocadas pelas cheias do rio, colocando o Bairro São José exposto ao risco iminente.

A construção do shopping Manaíra, a qual se sucedeu a impermeabilização e aterro da área provocando uma alteração no solo, é um dos grandes elementos que contribuiu para que o bairro hoje, seja constituído de tanta vulnerabilidade social. Além da presença de fatores que contribuem para ocorrência de enchentes no local, "essas áreas são consideradas de risco a enchente, por se localizarem na planície com altitudes inferiores aos 5m (cinco metros)" (ANDRADE; SANTOS 2012, p.4). As enchentes configuram um dos maiores problemas ambientais do Bairro São José, quando o fenômeno ocorre, além de colocar em risco muitas moradias, famílias e pessoas, dificultando o acesso a outras áreas, muitos estabelecimentos no bairro são fechados pela impossibilidade do acesso aos mesmos. 
O Bairro São José tem uma população de 7.078 habitantes em 2010, dados do censo demográfico do IBGE, sendo 52,0\% composto por mulheres e onde prevalece a faixa de escolaridade do ensino fundamental incompleto. A participação do governo municipal no tocante às melhorias de infraestrutura no bairro acontece de forma lenta ao longo de muitos anos e de grandes conflitos de urbanização.

Pode-se observar que hoje a comunidade possui uma única via de acesso transitável, que possibilita a passagem de automóveis, sendo esta via conhecida como a Rua Edmundo Filho, a principal via de acesso à comunidade, e por onde hoje passa o transporte coletivo que atende aos moradores, existem outras ruas que compõem o bairro, sendo elas a rua Projetada e rua do Rio, porém são ruas estreitas que não possuem condições de acesso de automóveis. Em contrapartida, a comunidade não possui escola pública, as crianças e adolescentes têm que se deslocarem para o Bairro de Manaíra, onde se localiza a Escola Estadual Alice Carneiro, que possui ensino médio e as Escolas de Ensino Fundamental Nazinha Barbosa da Franca, também no Bairro Manaíra, e a Escola Estadual Capitulina Sátyro, no bairro do João Agripino.

Importante destacar a interação da Escola Municipal Nazinha Barbosa da Franca com o Bairro São José, pois consiste em sua historicidade um processo de luta emancipatória para que a Escola consolide o seu local nas proximidades do Bairro São José. De acordo com o Projeto Político Pedagógico da Escola Nazinha Barbosa (2016), em 1994 a Escola Nazinha Barbosa funcionava na Rua Edmundo Filho, entretanto, nos anos de 1995 e 1996 o Rio Jaguaribe transbordou afetando inúmeras famílias, com isso a escola foi invadida pelos moradores. Em relação a isto, a Prefeitura Municipal decidiu transferir a Escola Nazinha, para Rua Maria Rosa, no Bairro de Manaíra, onde perdurou por seis meses.

Após esse período, tem-se outra mudança da Escola Nazinha, para outra Rua do Bairro de Manaíra, a Rua Eutiquiano Barreto, porém a escola permaneceu neste local por apenas oito meses. Só então em 1998 foi para a Rua Francisco Brandão, no 925/937, que estava situada em duas casas alugadas. Todo esse processo de remanejamento da localidade da Escola Nazinha Barbosa, só findou, definitivamente em 2005, em que a Prefeitura Municipal de João Pessoa, comprou um prédio e cedeu para a Escola Nazinha Barbosa, que permanece até os dias atuais, na mesma localidade, em Manaíra.

Desta forma, a relevância do Projeto de Extensão "O PROGRAMA BOLSA FAMÍLIA (PBF) E SUAS CONDICIONALIDADES NA EDUCAÇÃO: o acompanhamento e monitoramento dos (as) alunos (as) em descumprimento na Escola Municipal Nazinha Barbosa da Franca", é de

viabilizar que haja o cumprimento das condicionalidades do Programa Bolsa Família, como salientado anteriormente, grande parte do alunado são residentes do Bairro São José, de urbanização precária do Bairro, que constitui em sua territorialidade uma expressiva desigualdade social.

Importante salientar que o PBF incide em sua condicionalidade a perspectiva do direito social, principalmente para as famílias que estão em vulnerabilidade social, porém as implicações urbanas, a precariedade do próprio Bairro, implica no descumprimento da condicionalidade na Educação de crianças e adolescentes beneficiários do PBF, matriculados no Ensino Fundamental I e II, da referida Escola. Desse processo tem-se a negação do direto, a sua não efetividade. Uma contradição quando se espera que,

[...] A condicionalidade em educação do PBF gera também alguns resultados indiretos muito importantes, como a ênfase no campo educacional da desigualdade socioeconômica e da vulnerabilidade de alunos em situação de pobreza, o que está relacionado à valorização da permanência da criança e do adolescente na escola e o combate ao abandono e à evasão escolar, portanto, a fim de reforçar o percurso educacional regular como um direito, sem interrupções, dos alunos das famílias de baixa renda. (CURRALERO et al, 2010, p.165).

Contraposto a efetivação do direito, formula-se os seguintes dados coletados da realidade no tocante aos (as) alunos (as) do Ensino Fundamental I e II da Escola Nazinha Barbosa, representados nos quadros abaixo (Quadro I e II). 
Quadro 1 - Alunos Do Fundamental I, Beneficiários Do Pbf Em Descumprimento Da Frequência Escolar 2017

\begin{tabular}{|c|c|c|c|c|}
\multicolumn{2}{c}{$\begin{array}{c}\text { Alunos } \\
\text { Beneficiários do } \\
\text { PBF }\end{array}$} & $\begin{array}{c}\text { Descumpridores em } \\
\text { MAIO }\end{array}$ & $\begin{array}{c}\text { Descumpridores em } \\
\text { JUNHO }\end{array}$ & Descumpridores em JULHO \\
\hline $1^{\circ}$ ANO & 51 & 13 & 13 & 14 \\
\hline $2^{\circ}$ ANO & 54 & 15 & 9 & 28 \\
\hline $3^{\circ}$ ANO & 73 & 24 & 12 & 23 \\
\hline $4^{\circ}$ ANO & 70 & 18 & 15 & 14 \\
\hline $5^{\circ}$ ANO & 44 & 18 & 5 & 101 \\
\hline TOTAL & 292 & 88 & 54 & \\
\hline
\end{tabular}

Fonte: Elaboração Própria

Quadro 2 - Alunos do Fundamental II, beneficiários do PBF em descumprimento da frequência escolar - 2017

\begin{tabular}{|c|c|c|c|c|}
\hline & $\begin{array}{l}\text { Alunos Beneficiários do } \\
\text { PBF }\end{array}$ & $\begin{array}{c}\text { Descumpridores em } \\
\text { MAIO }\end{array}$ & $\begin{array}{l}\text { Descumpridores em } \\
\text { JUNHO }\end{array}$ & $\begin{array}{c}\text { Descumpridores em } \\
\text { JULHO }\end{array}$ \\
\hline 6응 ANO & 66 & 13 & 5 & 21 \\
\hline 7ㅇ ANO & 40 & 13 & 1 & 26 \\
\hline $8^{\circ}$ ANO & 27 & 8 & 5 & 12 \\
\hline 9o ANO & 26 & 3 & 1 & 8 \\
\hline TOTAL & 159 & 37 & 12 & 67 \\
\hline
\end{tabular}

Fonte: Elaboração Própria

Com base nos dados acima, constata-se que o alto índice de faltas dos alunos têm relação com as fortes chuvas que submerge o Rio Jaguaribe nos meses de maio, junho e julho, que totalizam no descumprimento de alunos (as) do Fundamental I em 243 alunos (as), referindo-se a 83\% e no Fundamental II em 116 alunos (as), equivalendo $72 \%$ do alunado. Outra situação é o acesso à Escola Nazinha, que com as cheias do Rio Jaguaribe às pontes que dão a possibilidade de chegar a Escola ficam inundadas, afetando os (as) alunos (as) no cumprimento da frequência escolar.

Desse modo, concordamos com Rolnik (2002), ao constatar na experiência de extensão que há uma relação estreita entre exclusão territorial e a violência urbana. A infra-estrutura urbana precária do bairro e a dificuldade de acesso a serviços e equipamentos é pressuposto para que uma política urbana integrada à política da assistência social possa dar resposta a estrutura profundamente desigual da cidade.

\section{CONCLUSÕES}

A experiência da pobreza marca de forma permanente as cidades no Brasil, ao passo em que traz em seu rastro situações de riscos e vulnerabilidades sociais de grandes contingentes de trabalhadores. São famílias que vivenciam um conjunto de desproteções, privações e necessidades, uma pobreza cotidiana absoluta, dado às condições aviltantes de sobrevivência.

Nesse estudo, constatou-se que às condições ambientais presentes no território e de infra- estrutura e serviços em que se insere o bairro São José, impactam no deslocamento e no acesso difícil à escola pelos seus moradores. 0 Bairro São José foi construído em região de manguezal às margens do Rio Jaguaribe. A escola se situa nas proximidades do bairro, no entanto, contraditoriamente está localizada no bairro de Manaíra, de classe média alta com infraestrutura, equipamentos e serviços ofertados na cidade.

Para os moradores do Bairro São José, principalmente nos meses de inverno, quando no Nordeste, especificamente em João Pessoa, têm-se fortes chuvas, ocorre a dificuldade das crianças e adolescentes do bairro acessarem a escola. Assim, a territorialidade, bem como, a não integralidade entre as políticas da habitação, da educação, da saúde e da assistência social, entre outras interferem no cumprimento das condicionalidades do PBF. A cidade é dividida em função das classes sociais e da divisão social do trabalho e a pobreza está confinada nos territórios. Encontramos imensas diferenças de acesso aos serviços sociais nas cidades, como é o caso da educação, uma verdadeira "exclusão territorial".

Desse modo, o direito à cidade e imerso nela o direito à moradia, a assistência social e ao acesso aos serviços de educação, uma forma particular de materialização do direito à cidade, se dá num contexto contraditório de classes e profundamente desigual, de leis avançadas na institucionalização de 
instrumentos de gestão urbana, qualificados de democráticos, mas de manutenção dos processos de apropriação privada da terra, mercantilização, de precarização da força de trabalho, de degradação de recursos ambientais e de reprodução da pobreza.

Assim o direito à cidade, ao que ela oferece em termos de equipamentos sociais, não é acessível à população de bairros de baixa renda, como é o caso do Bairro São José, mesmo apresentando como peculiaridade o fato de está localizado nas proximidades do Bairro de Manaíra, de classe média alta, em João Pessoa- PB.

Desse modo, concordamos com Rolnik (2002), ao constatar na experiência de extensão, que há uma relação estreita entre exclusão territorial e a violência urbana. A infra-estrutura urbana precária do bairro e a dificuldade de acesso a serviços e equipamentos é pressuposto para que uma política urbana integrada à política da Assistência Social possa dar resposta a estrutura profundamente desigual da cidade.

\section{REFERÊNCIAS}

[1] Andrade, Shirley Rodrigues de; SANTOS, Jocélio Araújo dos. A Cartografia da Suscetibilidade A Deslizamentos e Enchentes no Aglomerado Subnormal, Favela São José, João Pessoa (PB). Disponível em:<http://propi.ifto.edu.br/ocs/index.php/connepi/vii/paper/view/802/1592>. Acesso em: 05 set. 2017.

[2] Araújo, Jocélio. “Análise dos riscos ambientais relacionados às enchentes e deslizamentos na favela São José, João Pessoa - PB". Dissertação (Mestrado em Geografia) - Centro de Ciências Exatas e da Natureza, Universidade Federal da Paraíba, 2007.

[3] IBGE. Instituto Brasileiro de Geografia e Estatística. Censo Demográfico 2010. Disponível em < https://applocal.com.br/populacao/bairro/sao-jose/joao-pessoa/pb/>. Acesso em: 05 set. 2017

[4] Curralero, Cláudia Baddini, et al. As condicionalidades do programa bolsa família. In: Bolsa Família 20032010: avanços e desafios/ org: Jorge Abrahão de Castro, Lúcia Modesto. Brasília: Ipea, 2010. v.1. sec. I. Cap. 5. p. 151178.

[5] Cortez, J. C. V. Ocupação urbana em áreas de risco na cidade de João Pessoa (O caso da Comunidade São José). Dissertação (Mestrado em Desenvolvimento e Meio Ambiente) - Centro de Ciências Exatas e da Natureza, Universidade Federal da Paraíba, 169 f. 1999.

[6] gomes, Maria de Fátima Leite. O Programa Bolsa família (PBF) e suas condicionalidades na educação: o acompanhamento e monitoramento dos (as) alunos(as) em descumprimento na Escola Municipal Nazinha Barbosa da Franca - João Pessoa, 2017.

[7] Lima, Marco Antonio Suassuna; hugo, Victor. Reflexões sobre desenho urbano para o bairro São José João Pesso (PB). Disponível em: < http://www.vitruvius.com.br/revistas/read/arquitextos/14.162/4956>. Acesso em: 05 set. 2017

[8] Prefeitura Municipal de João Pessoa/Secretaria de Educação e Cultura.

[9] Projeto Político Pedagógico da Escola Municipal de Ensino Fundamental Nazinha Barbosa da Franca. João Pessoa-PB, 2016.

[10] Rolnik, Raquel. É possível uma política urbana contra a exclusão? In: Serviço Social e sociedade Ano XXII. n 72. São Paulo: Cortez, 2002. 


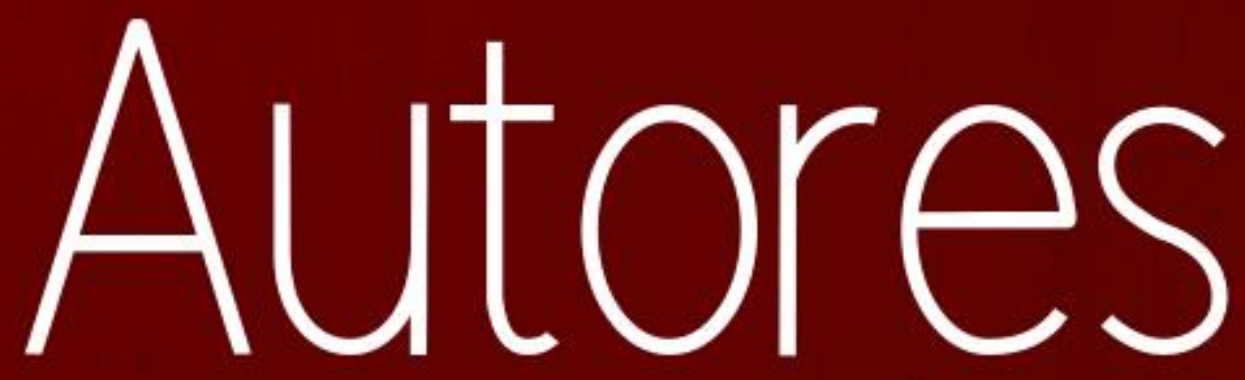




\section{ANA LÚCIA OLIVEIRA AGUIAR}

Graduada e Licenciatura em História pela Universidade Federal de Pernambuco (UFPE) Mestrado em Sociologia pela Universidade Federal de Pernambuco (UFPE) e Doutorado em Sociologia pela Universidade Federal da Paraíba (UFPB). Pós-Doutora pelo Programa de Pós-Graduação em Educação da Universidade Federal do Ceará (UFC) na linha de pesquisa Movimentos Sociais, Educação Popular e Escola. Tem Especialização em Inclusão pela Rede Municipal de Educação de Mossoró/RN. Atualmente é professora Adjunta IV da Universidade do Estado do Rio Grande do Norte (UERN). Membro dos Grupos de Pesquisa em Educação, Memória, (Auto) Biografia e Inclusão (GEPEMABI) da UERN e membro do Grupo de Estudos e Pesquisas em História da Educação do Ceará (GEPHEC), da Universidade Federal do Ceará. É professora do Programa de Pós-Graduação, Mestrado em Educação - POSEDUC/UERN. Vinculada ao Programa Interinstitucional de Doutorado em Ciências da Saúde (DINTER), Universidade Federal do Rio Grande do Norte e Universidade do Estado do Rio Grande do Norte, como co-orientadora. É Diretora da Diretoria de Políticas e Ações Inclusivas (DAIN), membro Titular da Comissão de Extensão da Pró-Reitoria de Extensão da UERN, membro representando a Diretoria de Políticas e Ações Inclusivas (DAIN), da Junta Multiprofissional da UERN.

\section{ANA PAULA MARQUES DE ARAÚJO}

Graduanda do curso de Letras Espanhol pela Universidade Estadual da Paraíba, UEPB. Membo da Associação de Professores de Espanhol do Estado da Paraíba- PB. Lecionou a disciplina de Espanhol no Ensino Fundamental II na Instituição de Rede Pública, e Atualmente é Professora de Espanhol no Ensino Infantil Fundamental I na Instituição de Rede Privada. Principais produções intituladas, O LÚDICO COMO FERRAMENTA DE INCLUSÃO NO PROCESSO DE ENSINO APRENDIZAGEM DO ESPANHOL COMO LÍNGUA ESTRANGEIRA. V. 1, 2018, ISSN 2359-2915, 2018. e LITERATURA INFANTIL COMO FERRAMENTA DE INCLUSÃO DE MODELOS FAMILIARES HOMOPARENTAIS. V. 1, 2018, ISSN 2359-2915, 2018. No III Congresso Internacional De Educação Inclusiva \& III Jornada Chilena Brasileira De Educação Inclusiva E Direitos Humanos.

\section{ANDRÊSSA GLAUCYARA SILVA RAMOS}

Graduanda do Curso de Licenciatura Plena em Pedagogia na Universidade Federal de Campina Grande (UFCG/CFP) - campus Cajazeiras-PB.

\section{APARECIDA CARNEIRO PIRES}

Pedagoga. Mestra e Doutora em educação. Professora Adjunta da Universidade Federal de Campina Grande. Coordena projetos sociais vinculados ao Programa de Extensão "Pedagogia Social: práticas educativas em contextos diversos".

\section{ARTHUR FURTADO BOGÉA}

Possui curso Superior em Bacharelado e Licenciatura Plena em Ciências Sociais pela Universidade Federal do Maranhão; Especialização em Docência do Ensino Superior e Sociologia e em Gestão Supervisão e Orientação Educacional; Mestrando do Programa de Pós-Graduação em Educação da Universidade Federal do Maranhão, atuando principalmente nos seguintes temas: gênero, sexualidade, identidade, discurso, corpo, relações sociais, gênero e educação.

\section{CAIO CÉSAR GOMES DE MOURA}

Graduando em Serviço Social pela Universidade Federal da Paraíba, monitor da disciplina de Fundamentos Históricos Teórico-metodológico do Serviço Social II, membro do Grupo de Estudos e Pesquisa em Educação Popular, Movimentos Sociais e Serviço Social - GEPEDUPSS e membro do Grupo de Estudo Trabalho, Educação e Serviço Social - GETESS. Extensionista no projeto "O programa bolsa família e suas condicionalidades na educação: acompanhamento e monitoramento dos/das alunos/alunas em descumprimento na Escola Municipal Nazinha Barbosa da Franca" de 2017-2018. 


\section{CAMILA MIRELLA BARBOSA RAIA DE OLIVEIRA}

Possuo graduação em Pedagogia pela Faculdade de Ciências Humanas de Olinda (FACHO), bacharel em Administração pela Universidade Católica de Pernambuco (UNICAP), especialista em Gestão Educacional pela Fundação de Ensino Superior de Olinda (FUNESO) e atualmente mestranda em Educação pela Universidade de Pernambuco (UPE). Participante desde 2016 do grupo de pesquisa da CNPQ vinculada a Universidade Federal de Pernambuco,Grupo de pesquisa do nepedh, estudos sobre a produção científica da educação em direitos humanos na área de educação, intitulado de Interlocuções entre educação em direitos humanos e formação de professores. Exerço cargo de Coordenadora Pedagógica na Rede Privada de Ensino . Sou Servidora Pública da Rede de Ensino da Prefeitura da Cidade do Recife, Professora Efetiva, exercendo a função de Professor I. Experiência na área de Educação, com ênfase em Avaliação do Ensino-Aprendizagem, Prática Pedagógica do Professor e Gestão Educacional, Interculturalidade e Direitos Humanos, atuando nos seguintes temas: práticas pedagógicas do professor, aprendizagem, avaliação, gestão, interculturalidade, direitos humanos e educação.

\section{CARLA THAYSE DOS SANTOS ALVES}

Graduanda em Licenciatura em Ciências Biológicas

\section{CELYANE SOUZA DOS SANTOS}

Bacharela no curso de graduação em Serviço Social pela Universidade Federal da Paraíba (UFPB) com ênfase na área de Educação, atuando em temas como o Programa Bolsa Família (PBF) e suas condicionalidades, Serviço Social, descumprimento da frequência escolar. Participou do Projeto de Extensão (PROBEX) intitulado: 0 PROGRAMA BOLSA FAMÍLIA (PBF) E SUAS CONDICIONALIDADES NA EDUCAÇÃO: o acompanhamento e monitoramento dos(as) alunos(as) em descumprimento na Escola Municipal Nazinha Barbosa da Franca, no qual, em 2016 foi discente colaboradora e em 2017 foi bolsista. Atualmente é Coordenadora do Serviço Egresso da Fundação do Desenvolvimento da Criança e do Adolescente "Alice de Almeida" (FUNDAC-PB), Membro do GT do Direitos Humanos da Criança e do Adolescente e Membro da Comissão Estadual de monitoramento do Plano de Convivência Familiar e Comunitária .

\section{CHARLES LAMARTINE DE SOUSA FREITAS}

Graduado em Serviço Social pela Universidade do Estado do Rio Grande do Norte (UERN) e em Teologia pelo Ateneo Pontificio Regina Apostolorum - Roma/Itália. Especialista em Metodologia e Docência do Ensino Superior pela Faculdade do Vale do Jaguaribe (FVJ). Mestre em Teologia pela Pontifícia Universidade Gregoriana - Roma/Itália. Mestre em Educação pela UERN. Doutorando em Educação pela Universidade Estadual de Campinas (UNICAMP), na área de Filosofia e História da Educação. Professor e Diretor Geral da Faculdade Católica do Rio Grande do Norte (FCRN). Membro do Grupo de Estudos e Pesquisas, Educação, Memória, (Auto) Biografia e Inclusão (GEPEMABI/POSEDUC/UERN). Membro do Grupo de Estudos e Pesquisas Paideia na Universidade Estadual de Campinas.

\section{DALNES CRISTINE DE FREITAS GONDIM}

Graduação em Serviço Social pela Universidade Federal da Paraíba (1987), especialização em Gestão Escolar pela Universidade Federal da Paraíba(2012), especialização em Serviço Social e Política Social pela Universidade de Brasília(2001) , Curso de aperfeiçoamento em Educação Pobreza e Desigualdade Social pela Universidade Federal da Paraiba (2018) Assistente Social/Agente Fiscal do Conselho Regional de Serviço de Social 13a Região -Paraíba e Assistente Social da Prefeitura Municipal de João lotada na Secretaria de Educação

\section{EDINA HENRIQUE DA SILVA BATISTA}

Possui Mestrado em Ciência da Educação e Multidisciplinaridade pela Universidade Gama Filho UGF (2015), Especialista em Ensino da Língua Portuguesa pela Faculdade de Tecnologia e Ciências 
- FATEC (2011), Especialista em Gestão Escolar da Escola de Gestores da Educação Básica do MEC pela Universidade Federal de Pernambuco - UFPE (2015). Licenciada em Letras pela Universidade Estadual Vale do Acaraú UVA (2009). Atualmente sou Professora efetiva (desde 2010) da educação básica, com atuação e experiência nos Anos Finais do Ensino Fundamental na Rede Municipal de Ensino de Bom Jardim- PE, e membro do grupo de pesquisa Interlocuções entre Educação Em Direitos Humanos, Currículo E Formação De Professores, através do Núcleo De Estudos E Pesquisas De Educação Em Direitos Humanos, Diversidade E Cidadania - NEPEDH.

\section{EDNA TANIA FERREIRA DA SILVA}

Possui Doutorado em Serviço Social pela Universidade Federal de Pernambuco (2014); Mestrado em Serviço Social pela Universidade Federal da Paraíba (1997);Graduação em Serviço Social pela Universidade Federal da Paraíba (1992). Atualmente é professor efetivo adjunto III da Universidade Federal da Paraíba. Tem experiência na área de Serviço Social e Políticas Sociais , atuando principalmente nos seguintes temas: Fundamentos do Serviço Social, Avaliação de Políticas Sociais , Usuários e Programas Sociais e Gestão em Politicas Sociais.

\section{EMYLE POMPEU DE BARROS DALTRO}

Desde 2013, é professora adjunta dos cursos de graduação em Dança da Universidade Federal do Ceará (UFC). Doutora em Arte pela Universidade de Brasília - UnB, mestra em Estudos de Cultura Contemporânea pela Universidade Federal de Mato Grosso - UFMT, tem especialização Lato Sensu em Planejamento e Gestão Cultural e graduação em Comunicação Social (jornalismo). Possui formação em Dança (Advanced e Teaching Certificate da Royal Academy of Dance); Foi bailarina da Cia. de Dança e Ballet de Mato Grosso e co-fundadora e intérprete-criadora do Grupo Casa - Artes do Corpo, em Cuiabá, MT, ganhando o prêmio Klauss Vianna em 2009, com o trabalho de dança "Pena que cocar não tem". Coordenou o projeto de extensão "Grande Roda: africanidades, ancestralidades e interculturalidade em movimentos" (2017-2018) e o Programa Institucional de Iniciação à Docência (PIBID) dos cursos de Licenciatura em Dança e Teatro da UFC (2018-2019). Coordena, junto à professora Consiglia Latorre, o grupo de pesquisa Sonoridades Múltiplas, do Instituto de Cultura e Arte da UFC, que trabalha com improvisação e composição em música e dança. Coordena o projeto de pesquisa e criação "Arte, decolonialidade e invenção".

\section{ESPEDITO DOS SANTOS JÚNIOR}

Graduando em Licenciatura em Ciências Biológicas

\section{FELIPE ALMEIDA GARCIA SANTOS}

Advogado, Bacharel em Direito pela Universidade Federal da Bahia (UFBA), pesquisador e exmembro associado do Centro de Estudos e Pesquisas Jurídicas (CEPEJ) da UFBA.

\section{FRANCILENE ARAÚJO DE MORAIS}

Doutora em Administração de Empresas pela Mackenzie-SP, na linha Gestão Humana e Social nas Organizações. Mestre em Psicologia Social pela UFPB. Graduação (Formação e Licenciatura) em Psicologia pela UFPB. Graduação em Administração e Pedagogia pela IBF (2019/ em curso). Leciona Métodos de Pesquisa e Psicologia, além de ocupar o cargo de coordenadora geral de Estágios Supervisionados e Monografias na UNIFACISA-CG/Pb. Experiências acadêmicas e administrativas a nível de Educação Superior, destacando as funções de Assessora da Pró-reitoria Adjunta de Graduação; Diretora do Centro de Humanidades; Coordenadora do curso de Psicologia e da Clínica de Psicologia da Universidade Tiradentes. Realiza capacitações docentes, palestras, consultorias e Treinamento de Colaboradores. 


\section{FRANCINILDA HONORATO DOS SANTOS}

Bacharelado em Teologia pelo Instituto Superior de Teologia Aplicada (2007). Especialização em Psicopedagogia pela mesma instituição - INTA (2010). Mestrado em Educação pelo Programa de Pós-graduação em Educação (POSEDUC) da Universidade do Estado do Rio Grande do Norte (UERN). Membro do Grupo de Estudos e Pesquisas em Educação, Memória, (Auto)Biografia e Inclusão (GEPEMABI/POSEDUC/UERN). Atualmente é secretária do Curso de Especialização em Educação da Universidade do Estado do Rio Grande do Norte onde ocupa o cargo de Técnico de Nível Superior.

\section{GABRIELA CAVALCANTI LUCENA}

Graduanda do Curso de Licenciatura Plena em Pedagogia na Universidade Federal de Campina Grande (UFCG/CFP) - campus Cajazeiras-PB.

\section{GERSON CARLOS MATIAS DE SOUSA (GERSON MORENO)}

Artista de dança (dançarino, coreógrafo e professor) com 30 anos de atuação no Ceará. Formou-se no Colégio de Dança do Ceará (Instituto Dragão do Mar - Fortaleza). É pedagogo formado pela Universidade Estadual do Ceará (UECE) com especialização em Educação Biocêntrica pelo Centro de Desenvolvimento Humano ( $\mathrm{CDH}$ ) e Mestre em Educação pela Universidade Federal do Ceará (UFC) onde investigou metodologias plurais de ensino e criação em danças afroancestrais e indígenas na educação formal e não formal . É diretor/fundador da Cia Balé Baião, coordenador pedagógico do Ponto de Cultura Galpão da Cena e curador do Festival de Dança do Litoral Oeste CE.

\section{GISELE ALVES XAVIER DA SILVA}

Graduanda do curso de Psicologia pela Universidade Federal da Paraíba, atuação em áreas de Educação e Trabalho. Atualmente extensionista bolsista do projeto de extensão (PROBEX) em andamento "O BULLYING NO CONTEXTO ESCOLAR: estratégias de combate e de prevenção à luz da Psicologia Escolar Educacional" e extensionista voluntária do projeto de extensão: SAÚDE DO TRABALHADOR NAS COMUNIDADES: COMPREENDENDO TRABALHO - SAÚDE - DOENÇA DE FORMA INTERDISCIPLINAR. Participou do Projeto de extensão (PROBEX) titulado: PROGRAMA BOLSA FAMÍLIA (PBF) E SUAS CONDICIONALIDADES NA EDUCAÇÃO: o acompanhamento e monitoramento dos(as) alunos(as) em descumprimento na Escola Nazinha Barbosa da Franca como extensionista voluntária em 2017, na graduação incompleta de Serviço Social pela Universidade Federal da Paraíba.

\section{IRAN DE MARIA LEITÃO NUNES}

Possui graduação em Pedagogia pela Universidade Federal do Maranhão (1981), Especialização em Orientação Educacional pela Pontifícia Universidade Católica de Minas Gerais (1990), Mestrado em Administração e Supervisão Escolar - American World University of Iowa (2000), Doutorado em Educação pela Universidade Federal do Rio Grande do Norte (2006), Pós-doutorado na Universidade Aberta de Lisboa (2013/2014). Atualmente é professora adjunta da Universidade Federal do Maranhão. Tem experiência na área de Educação, com ênfase em História da Educação, relações de gênero e Educação

\section{JOÃO ANTÔNIO DA SILVA FERNANDES}

Graduando em Licenciatura em Ciências Biológicas

\section{JOÃO ANTÔNIO DE SOUSA LIRA}

Graduado em Licenciatura em Pedagogia Pela Universidade Federal do Piauí, Campus Amílcar Ferreira Sobral, Floriano-PI. Especialista em Educação Especial e Neuropsicopedagogia pela Universidade Cândido Mendes (UCAM), e em Psicologia da Educação pela Universidade Estadual 
do Maranhão (UEMA). Mestrando em Educação Pela Universidade Federal do Maranhão(UFMA) na linha de pesquisa em História, Políticas Educacionais, Trabalho e Formação Humana.

\section{JOSÉ EVANGELISTA LIMA}

Graduação Licenciatura e Bacharelado em Psicologia pela Universidade Federal da Paraíba (1981). Possui curso de Especialização em Psicologia e Saúde pela Universidade Federal do Rio Grande do Norte (1990). Tem licenciatura Plena em Pedagogia com Habilitação em Supervisão Escolar pela Universidade do Estado do Rio Grande do Norte. Mestre em Educação pela UERN. É professor Adjunto IV da UERN (Mossoró). Psicólogo da Secretaria de Saúde Pública do RN/SESAP, atuando no Hemocentro de Mossoró/RN. Membro do Grupo de Estudos e Pesquisas em Educação, Memória, (Auto) Biografia e Inclusão (GEPEMABI/POSEDUC/UERN).

\section{KÉZIA SIMÉIA BARBOSA DA SILVA MARTINS}

Doutora em Educação pela Universidade Federal do Amazonas. Pedagoga e Professora na Universidade Federal do Amazonas, Instituto de Ciências Sociais, Educação e Zootecnia (ICSEZ/UFAM) no município de Parintins-AM. Tem experiência na área de Educação, com ênfase em: Formação de Professores, Currículo Escolar e Identidades Amazônicas, Práticas Pedagógicas, Metodologia Educacional e Projetos de Pesquisa.

\section{LETICIA PRISCILA AZEVEDO DE SOUSA}

Graduada em Biblioteconomia pela Universidade Federal do Estado do Rio de Janeiro (2004), Especialista em Gestão Eletrônica de Documentos pelo Centro Universitário Augusto Motta (UNISUAM/2009). Mestre em Ciências da Educação pela Universidad Columbia del Paraguay (2015-2018). Atualmente é bibliotecária documentalista da Universidade Federal do Rio de Janeiro. Tem experiência na área de Ciência da Informação, com ênfase em Biblioteconomia, atuando principalmente nos seguintes temas: processamento técnico e setor de referência. Na área de educação, pesquisa na área de Educação inclusiva/especial.

\section{LIÉLIA BARBOSA OLIVEIRA}

Possui graduação em História (2009) e Serviço Social (2013) pela Universidade Estadual da Paraíba, Mestrado em História pela Universidade Federal de Campina Grande (2012). Pesquisadora do Projeto Histórico-documental Catálogo Geral de Documentos de História Indígena e Escravidão Negra desenvolvido pela Fundação Parque Tecnológico da Paraíba; em parceria com a UFCG; com financiamento da Petrobrás e pesquisadora do Projeto resgate documental, história ambiental e etnohistória do semiárido brasileiro nos períodos colonial e imperial no Instituto Nacional do Semiárido (INSA). Atualmente é pesquisadora integrante do Núcleo de estudos sobre Elites, Famílias e Desigualdades - NEFADE- da Unidade Acadêmica de Ciências Sociais da UFCG.

\section{LUZIA AREAL BARROS}

Mestre em Ciência da Educação, Univesidad Columbia del Paraguay, Assunção. Bacharel em Biblioteconomia, pela UNIRIO, Especialista em Gestão Pública, pela FIJ. Servidora Público Federal da Universidade Federal do Rio de Janeiro.

\section{MAGDIEL JÚNIOR DA SILVA}

Graduando concluinte de Letras com habilitação em língua inglesa pelo Centro de Educação da Universidade Estadual da Paraíba (UEPB). Habilitado em Inglês (Advanced English) pelo Teacher's training course pelo Centro Cultural Anglo-Americano (CCAA). Extensionista bolsista associado ao projeto de monitoria em Teoria da Narrativa e Literatura Colonial pela UEPB. Atualmente leciona a disciplina de língua inglesa para o Ensino Fundamental e Médio em instituições da rede pública e privada. É um dos sócios fundadores e membro da diretoria de Línguas Estrangeiras e Literatura do Instituto Interdisciplinar de Educação, História e Cultura (INSIEDUHC). Principal produção 
intitulada Literatura Infantil como Ferramenta de Inclusão de Modelos Familiares Homoparentais. 2018. III Congresso Internacional De Educação Inclusiva \& III Jornada Chilena Brasileira De Educação Inclusiva E Direitos Humanos.

\section{MARCOS PAULO DE OLIVEIRA SOBRAL}

Professor Assistente da Universidade Federal de Alagoas - Campus Arapiraca/Unidade Educacional de Penedo. Professor do Curso de Ciências Biológicas - Modalidade Licenciatura.

\section{MARIA APARECIDA PEREIRA}

Graduada em Serviço Social pela Universidade Federal da Paraíba - UFPB, com experiência na área da Educação, onde atuou em temas como Programa Bolsa Família e suas condicionalidades, Serviço Social, Inclusão Escolar, Bullying, Violência na Escola. Em 2015 foi colaboradora na primeira fase do Projeto de Extensão (PROBEX) intitulado O PROGRAMA BOLSA FAMÍLIA (PBF) E SUAS CONDICIONALIDADES NA EDUCAÇÃO: o acompanhamento e monitoramento dos(as) alunos(as) em descumprimento na Escola Municipal Nazinha Barbosa da Franca. Em 2016 foi bolsista na 2a fase do supracitado Projeto de Extensão. Pesquisadora do Projeto de Pesquisa intitulado "Prisão e Educação um hiato histórico: da cela à sala de aula, um caminho para a educação ao longo da vida?". Autora do livro Violência Escolar - Aspectos que contribuem para essa prática, publicado em 2017 pela Editora Novas Edições Acadêmicas, Düsseldorf, Alemanha.

\section{MARIA DAYANNY GONCALVES}

Graduanda do Curso de Licenciatura Plena em Pedagogia pela Universidade Federal de Campina Grande (UFCG), membro voluntário no Grupo de Estudos e Pesquisa em Filosofia e Educação (GEPEFE), Ex-bolsista do Programa Institucional de Bolsas de Iniciação Científica (PIBIC).

\section{MARIA DE FATIMA ANDRADE COSTA HENRIQUES}

Possui doutorado em CIENCIA DA EDUCAÇÃO - Universidad Americana del Paraguay (2017) e mestrado em CIENCIA DA EDUCAÇÃO - Universidad Americana del Paraguay (2012). Atualmente é professor da Escola de Ensino Superior Fabra. Tem experiência na área de Educação, com ênfase em Ensino-Aprendizagem, atuando principalmente nos seguintes temas: pedagogo empresarial, alimentação escolar;, financiamento da merenda escolar, educação continuada e aprendizagem.

\section{MARIA DE FÁTIMA LEITE GOMES}

Possui graduação em Serviço Social pela Universidade Federal da Paraíba (1987), Especialização em Metodologia das Ciências pela Universidade Estadual da Paraíba (1991), Mestrado em Serviço Social pela Universidade Federal da Paraíba (1997) e Doutorado em Serviço Social pela Universidade Federal de Pernambuco (2011), na Área de Concentração em Serviço Social, Movimentos Sociais e Direitos Sociais. É professora da Universidade Federal da Paraíba atuando na Graduação e no Programa de Pós-Graduação em Serviço Social da Universidade Federal da Paraíba (UFPB).. Tem experiência na área de Serviço Social, com ênfase em Política de Assistência Social, Fundamentos do Serviço Social e Movimentos Sociais. Foi Chefe do Departamento de Serviço Social da UFPB, no período 2001-2006, e Vice-Presidente Regional da Associação Brasileira de Ensino e Pesquisa em Serviço Social (ABEPSS), no período 2003-2004. Ministrou disciplinas na PósGraduação (lacto-sensu) em Serviço Social da UFPB, além de participação em Cursos de formação de curta duração. Foi colaboradora do Conselho Municipal de Assistência Social (CMAS), de João Pessoa-PB., entre 2013-2014. Orienta e coordena projeto de extensão e projetos de iniciação científica (PIBIC e PIVIC), vinculados à UFPB e ao CNPQ, respectivamente. É a segunda líder do Grupo de Estudos e Pesquisas em Educação Popular, Serviço Social e Movimentos Sociais (GEPEDUPSS), vinculado ao Departamento de Serviço Social e ao Programa de Pós-Graduação em Educação (PPGE), da UFPB. Foi Membro da Associação Latinoamericana de Sociologia, no período correspondente a 2013-2015. É vice-chefe do Departamento de Serviço Social da UFPB, desde 2016. 


\section{MARIA ELUIZA SOARES DA SILVA}

Graduanda em Licenciatura em Ciências Biológicas

\section{MARIA GORETTI RODRIGUES DE SOUSA OLIVEIRA}

Graduada em Serviço Social pela Universidade Federal da Paraíba(UFPB), experiência na Educação. Com ênfase nos seguintes temas: Educação, Programa Bolsa Família e suas condicionalidades, Serviço Social, Inclusão Escolar, Bullying, Violência na Escola. 2015 - Colaboradora na primeira fase do Projeto de Extensão intitulado 0 PROGRAMA BOLSA FAMÍLIA (PBF) E SUAS CONDICIONALIDADES NA EDUCAÇÃO: o acompanhamento e monitoramento dos(as) alunos(as) em descumprimento na Escola Municipal Nazinha Barbosa da Franca .2016, Bolsista na segunda fase do referido Projeto. 2016 Bolsista na segunda fase do Projeto supracitado; Desenvolveu atividade de Monitora Voluntária no PROJETO DE MONITORIA da disciplina Ética em Serviço Social, orientada pela Prof ${ }^{-}{ }^{-a}{ }^{\underline{a}} M^{a}$ de Fátima Leite Gomes. Pesquisadora do Projeto de Pesquisa intitulado "Prisão e Educação um hiato histórico: da cela à sala de aula, um caminho para a educação ao longo da vida?". 2017- Autora do livro Violência Escolar - Aspectos que contribuem para essa prática, Editora Novas Edições Acadêmicas, Düsseldorf, Alemanha 2018.Graduanda em Psicopedagogia pela Universidade Federal da Paraíba (UFPB) 2019.

\section{MARIA GRACIELLE VIEIRA PEDROZA}

Graduanda do Curso de Licenciatura Plena em Pedagogia na Universidade Federal de Campina Grande (UFCG/CFP) - campus Cajazeiras-PB.

\section{MARIA LUISA MENDES TEIXEIRA}

Graduação em Educação pela PUC de São Paulo (1972), mestrado em Administração de Empresas pela PUC do Rio de Janeiro (1988), doutorado em Administração pela Universidade de São Paulo (1995) e pós-doutorado pela Universidad Complutense de Madrid e pelo ISCSP/Portugal. Atualmente é profa. do Programa de Pós-Graduação em Administração de Empresas da Mackenzie e Profa. convidada do ISCTE - IUL (Portugal). Ocupa o cargo de Coordenadora Geral de Pesquisa da Mackenzie e a presidência da AIETORG-Associação Internacional de Estudos Transculturais e Organizacionais com sede em Lisboa. Dedica-se ao estudo de valores e Dignidade Organizacional. Lidera e participa de projetos em parcerias com outros pesquisadores nacionais e estrangeiros.

\section{ME. CIBELLE JOVEM LEAL.}

Graduada em História pela Universidade Estadual da Paraíba-UEPB; Mestra em História pela Universidade Federal de Campina Grande - UFCG como bolsista CAPES. Integra o Grupo de Estudos de Gênero e Sexualidade Flor e Flor, e o Núcleo de Estudos Afro-Brasileiros e Indígenas - NEABI da UEPB. Pesquisadora do Projeto Histórico-documental Catálogo Geral de Documentos de História Indígena e Escravidão Negra desenvolvido pela Fundação Parque Tecnológico da Paraíba; em parceria com a UFCG; com financiamento da Petrobrás e pesquisadora do Projeto resgate documental, história ambiental e etnohistória do semiárido brasileiro nos períodos colonial e imperial no Instituto Nacional do Semiárido (INSA).

\section{NÁJILA BRANDÃO DA SILVA}

Graduada em Serviço Social pela Universidade Federal da Paraíba e Especialista em Psicopedagogia Clínica e Escolar pelo Instituto de Ciências Sociais e Humanas. Atualmente atua como Assistente Social na Saúde e na Assistência Social. Tem experiência na áreas de Educação, com ênfase nos temas Programa Bolsa Família e sua condicionalidades, Inclusão Escolar, Evasão Escolar, Bullying, Violência Escolar e Serviço Social na Educação; Saúde com ênfase de atuação em Urgência e Emergência e; Assistência Social com ênfase de atuação na Política de Proteção Social Básica e de Média Complexidade. 


\section{ROBÉRIA VIANA CORREIA DE SOUZA}

Graduanda em Serviço Social pela Universade Federal da Paraíba (UFPB). Ex monitora da disciplina Trabalho e Sociabilidade (componente curricular obrigatório para obtenção do grau de Bacharel em Serviço Social pela UFPB; ex estagiária de Serviço Social no Tribunal de Justiça do Estado da Paraíba: ex estagiária em Serviço Social no Hospital Napoleão Laureano; ex estagiária de Serviço Social na Maternidade Cândida Vargas; ex participante do Grupo de Pesquisa EULE Filosofia e Crítica Social da UFPB; ex participante do Projeto de Extensão: O programa Bolsa Família e o descumprimento de suas condicionalidades na Escola Nazinha Barbosa da Franca.

\section{SILVANA SANTOS ALMEIDA}

Mestre pela Universidade Federal da Bahia no Programa de Pós Graduação Estudos Interdisciplinares sobre a Universidade cujo escopo da sua dissertação foi o Direito à Educação e Políticas Públicas. Graduada em Pedagogia pela Faculdade de Educação da Bahia (1989), em Serviço Social pela Universidade Católica do Salvador (1991) e em Direito pela Universidade Federal da Bahia (1998). Educadora há 27 anos com experiência em Educação Corporativa, Formação de Líderes Educacionais e de docentes.

\section{SIMONE RODRIGUES BATISTA MENDES}

Doutora em ciências de La Educación pela Universidad Evangélica del Paraguay, Mestre em Educación: Planicicación,Innovación y Gestión de la Prática Educativa, pela Universidad de Alcalá, Especialista Supervisão Escolar e graduada em Letras. Professora da Educação Básica e superior professora colaboradora da Licenciatura Intercultural do Instituto Insikiran - Universidade Federal de Roraima (UFRR), Assessora Técnica da União Municipal dos Dirigentes de Educação Municipal de Roraima . Membro dos Grupos de Pesquisas: Línguas, Culturas, Inclusão e Diversidade ( LinCIDUFRR ) e Povos, línguas e educação indígena ( PLEI/UFRR). Professora Universidad Evangélica del Paraguay. Com experiência de gestão de sistemas . Na docência do ensino superior atua com os temas: Formação de Professores, Gestão Democrática, Projeto Político Pedagógico, Legislação Educacional, Avaliação Institucional, Fundamentos da Educação, Gestão de Escolar e Coordenação Pedagógica, Gestão Democrática, Avaliação institucional , Educação Escolar Indígena, Formação do educador educação infantil.

\section{STENIO DE BRITO FERNANDES}

Graduação e Licenciatura em Geografia pela Universidade do Estado do Rio Grande do Norte (1999). Especialista em História do Brasil República pela UERN (2005). Especialista em Mídia na Educação pelo Núcleo de Educação a Distância (NEAD/UERN) (2015). Mestrado em Educação pelo Programa de Pós-graduação em Educação (POSEDUC/UERN). Membro do Grupo de Estudos e Pesquisas em Educação, Memória (Auto) Biográfica e Inclusão (GEPEMABI/UERN). Atualmente é professor estatutário no município de Porto do Mangue/RN (2003). Concursado do Estado do Rio Grande do Norte (RN) (2006). https://orcid.org/0000-0001-6300-9561

\section{TEREZA CRISTINA BERNARDO DA CÂMARA}

Professora Formadora do Instituto de Educação Superior Presidente Kennedy, desde 2004 até os dias atuais. Graduada em Educação Física, especialista em Educação Física Infantil e Mestre em Educação, todos pela Universideda Federal do Rio Grande do Norte. Instrutora de Yôga (Hatta Yôga), Reikiana e estudiosa da complexidade humana. Na formação de professores realiza vivências corporais, numa perspectiva humanescente, no intuito de provocar reflexões que estimulem o autoconhecimento e a transformação das pessoas, bem como um olhar sensível para a dimensão espiritual e o amor. 


\section{ZILDIANE SOUZA TEIXEIRA}

Estudante de Graduação em Pedagogia na Universidade Federal do Amazonas. Pesquisadora pelo Programa Institucional de Bolsas de Iniciação Científica (PIBIC) com ênfase em Educação, Currículo e Práticas pedagógicas. 


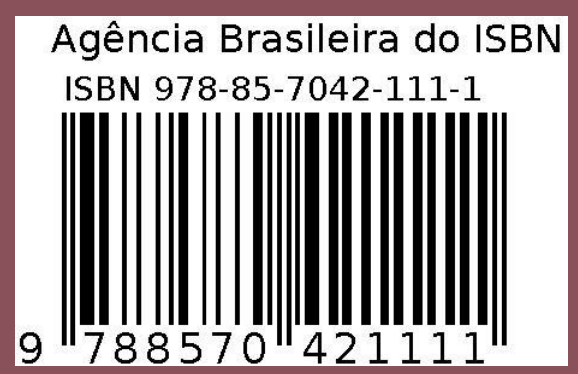

